Editora Poisson

\section{Tópicos em Ciências Agrárias Volume 4}

1a Edição

Belo Horizonte

Poisson

2020 


\section{Editor Chefe: Dr. Darly Fernando Andrade}

\section{Conselho Editorial}

Dr. Antônio Artur de Souza - Universidade Federal de Minas Gerais

Msc. Davilson Eduardo Andrade

Dra. Elizângela de Jesus Oliveira - Universidade Federal do Amazonas

Msc. Fabiane dos Santos

Dr. José Eduardo Ferreira Lopes - Universidade Federal de Uberlândia

Dr. Otaviano Francisco Neves - Pontifícia Universidade Católica de Minas Gerais

Dr. Luiz Cláudio de Lima - Universidade FUMEC

Dr. Nelson Ferreira Filho - Faculdades Kennedy

Ms. Valdiney Alves de Oliveira - Universidade Federal de Uberlândia

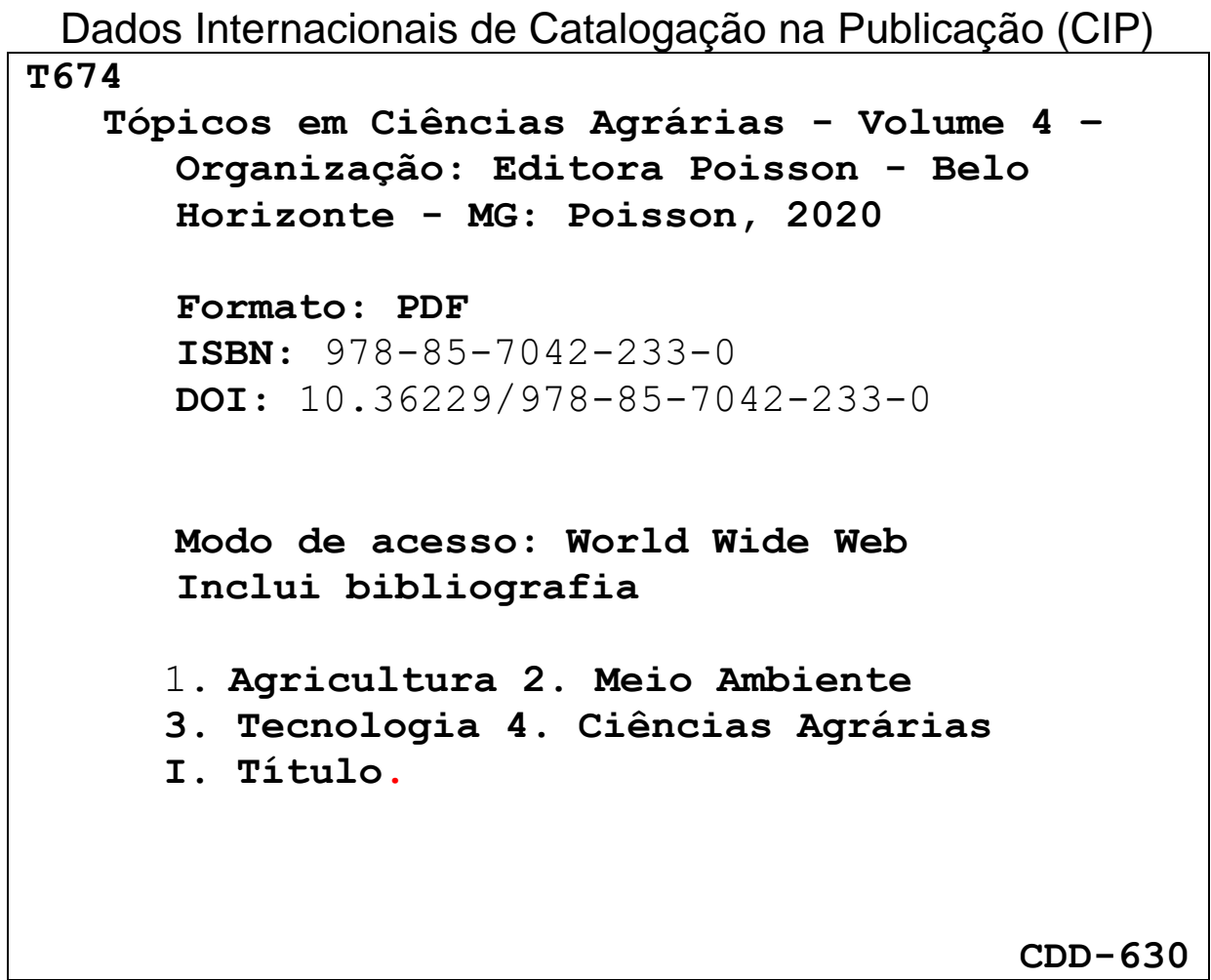

O conteúdo dos artigos e seus dados em sua forma, correção e confiabilidade são de responsabilidade exclusiva dos seus respectivos autores

www.poisson.com.br

contato@poisson.com.br 


\section{SUMÁRIO}

Capítulo 1: Balanço hídrico climatológico normal mensal no Estado de Goiás 06

João José da Silva Júnior, Mariana Nardi Furtado, Matheus Barcelos de Sousa

DOI: 10.36229/978-85-7042-233-0.CAP.01

Capítulo 2: Produtividade da água do feijoeiro comum irrigado 15

Chaiane Guerra da Conceição, Adroaldo Dias Robaina, Marcia Xavier Peiter, João Antônio da Conceição, Ana Rita Costenaro Parizi, Ana Carla dos Santos Gomes

DOI: $10.36229 / 978-85-7042-233-0 . C A P .02$

Capítulo 3: Teor de água do solo sob diferentes plantas de cobertura e preparo do solo em área de cana-de-açúcar 19

Maria Cecilia Vieira Totti, Zigomar Menezes de Souza, Ingrid Nehmi de Oliveira, Camila Vieira Viana Farhate, Lenon Henrique Lovera, Elizeu Souza Lima

DOI: $10.36229 / 978-85-7042-233-0 . C A P .03$

Capítulo 4: Inativação de coliformes por lâmpadas ultravioletas submersas em águas residuárias 24

Gabriela de Luzia Barros Mesquita, Fátima Resende Luiz Fia, Débora Ester Santos Fialho DOI: $10.36229 / 978-85-7042-233-0 . C A P .04$

Capítulo 5: Acompanhamento da aplicação de nitrogênio em cobertura em lavouras de trigo com aeronave remotamente pilotada. 41

Fábio Leonardo Prante Bolfe, Edivan Santin, Cristiano Reschke Lajús, Claudia Klein, André Sordi, Alceu Cericato

DOI: 10.36229/978-85-7042-233-0.CAP.05

Capítulo 6: Manejo da fertirrigação nitrogenada na cultura do alho-poró 47

Karoline Kovaleski Bertoldo Drehmer, Cristiane Dalagua Paier, Guilherme Augusto Bíscaro, Luciano Oliveira Geisenhoff, Gabriel Queiroz de Oliveira, Alice Rodrigues de Souza, Luciana Aparecida Maurício da Silva, Paulo Sergio Vieira Filho

DOI: 10.36229/978-85-7042-233-0.CAP.06

Capítulo 7: Análise do carbono orgânico no solo em lote irrigado com repolho na Região Agreste de Pernambuco- PE. 54

Eduardo Silva dos Santos, Abelardo Antônio de Assunção Montenegro, Luiz Guilherme Medeiros Pessoa, Job Teixeira de Oliveira, Plinio Antonio Guerra Filho, Carlos Augusto Alves Cardoso Silva, Eduardo Arouche da Silva, Ana karla da Silva Oliveira DOI: $10.36229 / 978-85-7042-233-0 . C A P .07$

Capítulo 8: Estudo do manejo de irrigação via solo e via clima na cultura do milho . 59 Ana Rita Costenaro Parizi, Gideon Ujacov Silva, Otávio Pivoto, Monique Denis Cabral, Chaiane Guerra da Conceição, Ana Carla dos Santos Gomes DOI: 10.36229/978-85-7042-233-0.CAP.08 


\section{SUMÁRIO}

Capítulo 9: Atributos físicos de um latossolo vermelho-amarelo submetido a diferentes sistemas de manejo. 63

Luiz Fernando Costa Ribeiro Silva, Letícia Almeida, Alberto Carvalho Filho DOI: 10.36229/978-85-7042-233-0.CAP.09

Capítulo 10: Regionalização do vigor de plantas através do uso de séries históricas de imagens orbitais 73

Leandro Maria Gimenez, Davi Gabriel Azevedo Besson

DOI: 10.36229/978-85-7042-233-0.CAP.10

Capítulo 11: Contribuições para metodologia de avaliação de imagens termográficas de equinos 86

Juliana Sarubbi, Vitor Inácio Hoelscher, Saionara Pereira Xavier, Diego Henrique dos Santos, Gabriela Cavalheiro Croda

DOI: $10.36229 / 978-85-7042-233-0 . C A P .11$

Capítulo 12: Desenvolvimento do protótipo de uma semeadora conservacionista para agricultura familiar. 96

Rafaela Paula Melo, Daniel Albiero, Max César de Araújo, Iury Alberto Mota de Lima, Luís Gustavo Chaves da Silva

DOI: $10.36229 / 978-85-7042-233-0 . C A P .12$

Capítulo 13: Acidentes com tratores agrícolas na Região do Alto Vale do Itajaí - SC. 100

Gabriel Ganancini Zimmermann, Fabrício Campos Masiero, Ricardo Kozoroski Veiga, João Célio de Araújo, Djeimes Luiz Sadowski Celante, José Carlos Kusma, Adelino do Amaral

DOI: $10.36229 / 978-85-7042-233-0 . C A P .13$

Capítulo 14: Avaliação econômica da influência dos tipos de rodado no consumo de combustível em trator agrícola.

Aldir Carpes Marques Filho, Jefferson Sandi, Murilo Battistuzzi Martins, Maura Seiko Tsutsui Esperancini, Kléber Pereira Lanças

DOI: 10.36229/978-85-7042-233-0.CAP.14

Capítulo 15: Bambucilga: Uma alternativa para criação de suínos e a conformidade orgânica.

Luã Carlos Colaço, Cátia Hermes, Eduardo Javier Marone, Valcir Inácio Wilhelm, Fabiana Teixeira Hoinacki DOI: 10.36229/978-85-7042-233-0.CAP.15

Autores: 


\section{Capitulo 1}

\section{Balanço hídrico climatológico normal mensal no Estado de Goiás}

\section{João José da Silva Júnior \\ Mariana Nardi Furtado \\ Matheus Barcelos de Sousa}

Resumo: A deficiência hídrica é uma das responsáveis pela queda de produção na Agricultura assim conhecer a disponibilidade da água no solo para um futuro planejamento é a base para executar o seu uso racional. Diante disso, este trabalho teve como objetivo elaborar o balanço hídrico mensal para oito mucípios do estado de Goias, Aragarças, Catalão, Formosa, Goiânia, Jataí, Mineiros, Pirenópolis e Rio Verde. 0 balanço hídrico foi determinado a partir do método de Thorthwaite e Mather (1955) com dados obtidos diretamente do INMET referente ao período de 1961 a 1990 considerou-se uma Capacidade de Água Disponível (CAD) de $100 \mathrm{~mm}$. Para os munícipios avaliados o balanço hídrico demostrou que existem duas estações climáticas bem definidas, uma chuvosa de outubro/novembro a abril e outra seca, de maio a setembro/outubro. Goiânia foi o município que apresentou o maior déficit hídrico e o município de Formosa apresentou menor déficit hídrico. 0 município que possui a maior parte das suas chuvas concentrada no período de excedente hídrico é o município de Jataí, com 65,63\% das suas chuvas concentradas de novembro a abril. 0 município que possui a menor parte das suas chuvas concentradas nesses meses é o município de Mineiros com 59,09\% de suas chuvas nos meses assinalados.

Palavras chave: relações hídricas; gestão hídrica; defíct hídrico; precipitação. 


\section{INTRODUÇÃO}

Ao longo dos séculos, a humanidade vem procurando desenvolver técnicas de manejo do solo, da água e dos recursos disponíveis a fim de melhorar sua qualidade de vida e permanência nos territórios. Os fatores determinantes para a permanência da espécie humana em determinada região são a disponibilidade de água, o clima e a produtividade do solo, a qual é em grande parte dependente dos dois primeiros.

O manejo da água é item de extrema importância para a boa gestão dos recursos hídricos e consequentemente para dimensionar a disponibilidade hídrica de uma região, permitindo um planejamento da produção agrária mais racional e sustentável. Embasado em dados climatológicos locais, o balanço hídrico climatológico é uma ótima ferramenta para o gerenciamento e classificação do clima, zoneamento agroclimático e ambiental, distinção de períodos de seca e de disponibilidade hídrica, além de favorecer um manejo integrado dos recursos hídricos de uma região. (LIMA e SANTOS, 2009).

O balanço hídrico pode ser considerado a primeira contabilização da disponibilidade de água de uma região, onde procura-se definir os períodos secos, ou seja, períodos de deficiência hídrica, e os períodos úmidos, ou seja, perídios de excedente hídrico, embasando um planejamento agrário mais eficaz, identificando onde as culturas podem ser exploradas e onde existem impasses ambientais para sua produção. Segundo, Pereira, Angelocci e Sentelhas (2002), os principais componentes de um balanço hídrico climatológico são a precipitação média, a evapotranspiração real, a evapotranspiração potencial, o armazenamento de água no solo, a deficiência hídrica e o excedente hídrico, esses dois últimos calculados a partir dessas outras variáveis.

O método mais comum para a realização do Balanço Hídrico climatológico é o método de Thornthwaite \& Mather (1955), esse método é utilizado para a caracterização da disponibilidade hídrica de uma região, utilizando bases climatológicas e comparativas. A vantagem do método de Thornthwaite é que são necessários apenas dados de temperatura do ar e das coordenadas geográficas do local, onde o método é capaz de estimar a temperatura média mensal pelas coordenadas geográficas do local. Portanto, para realizar o balanço hídrico climatológico normal, é necessário somente dados de precipitação mensal (representando a principal entrada de água no solo) e as coordenadas geográficas do local.

0 método diferencia dois tipos de evapotranspiração. A evapotranspiração potencial, que é definida como a máxima perda de água na forma de vapor para a atmosfera, geralmente ocorre em uma vegetação que cobre totalmente a superfície do solo, sem restrições de água no solo, essa variável é tomada como elemento de referência para estudos comparativos da perda de água em diferentes locais de estudo. E a evapotranspiração real, a qual se diferencia da potencial pois existe uma condição de restrição de água no solo associada a produção vegetal naquele local.

O conhecimento dessas variáveis se faz muito interessante pois, através delas é possível a estimativa e planejamento de uma produção agrícola, tornando o ou a produtora cientes das condições edafoclimáticas de seu interesse a fim de embasar o planejamento de uma produção agrícola sustentável, mostrando quais são os melhores meses para plantio, como também quais métodos e tipos de cultivos serão realizados no local, seja optando pela irrigação da produção, seja optando por métodos de plantio mais conservacionistas no que diz respeito a água no solo, como por exemplo, sistemas agroflorestais.

\section{OBJETIVO}

Esse trabalho tem como objetivo realizar o estudo do Balanço Hídrico Climatológico normal mensal em diversos municípios do Estado de Goiás, a fim de gerar conhecimento para o embasamento de planejamentos integrados de produção agrária, onde se busque consorciar a produção agrícola e a sustentabilidade ambiental do sistema em questão.

\section{MATERIAIS E MÉTODOS}

0 trabalho em questão foi realizado no Estado de Goiás, tendo como base o estudo das normais

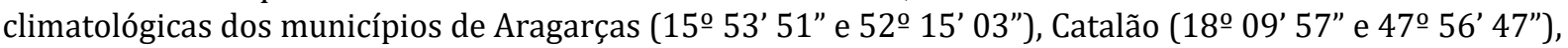

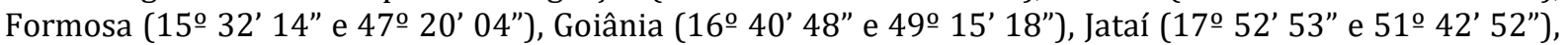

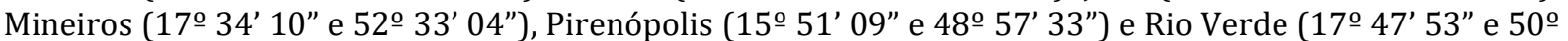
$\left.55^{\prime} 41^{\prime \prime}\right)$. 
Foram utilizados os dados de precipitação média mensal e temperatura média mensal, coletados durante o período de 30 anos e disponibilizados pelo Inmet (Instituto Nacional de Meteorologia).

O balanço hídrico médio mensal foi elaborado a partir do método desenvolvido por Thothwaite e Mather (1955) apresentado por Pereira, Angelocci e Sentelhas (2002). Para seu cálculo foram utilizados dados históricos e as normais climatológicas dos anos de (1961-1990). A precipitação média mensal e a evapotranspiração de referência foram estimadas pela equação de Penman Monteith (ALLEN et al., 1998).

Considerando a disponibilidade hídrica da regiçao utilizou-se uma Capacidade de Água Disponível (CAD) média de $100 \mathrm{~mm}$, e a partir dos dados iniciais de precipitação e temperatura, foi calculada e evapotranspiração de referência, e então foi possível determinar o balanço hídrico médio mensal para cada região estudada. Com base nos resultados obtidos sobre o balanço hídrico de cada munícipio determinou-se os períodos mais críticos em relação a deficiência hídrica e os períodos onde a água é mais abundante no sistema.

A evapotranspiração define-se como o resultado total da perda da água para atmosfera da superfície do solo e das plantas. 0 método para se medir a evapotranspiração mais utilizado no Brasil, segundo Tubelis (1986) trata-se de recipientes enterrados e cheios com o mesmo solo de uma escavação, cobertos por vegetação. A superfície graduada do evapotranspirômetro deve estar no mesmo nível do gramado A medida da transpiração potencial é contabilizada pelo total de água, que é usado pela planta em um dia, determinado pela diferença entre a quantidade de água colocada e a percolada:

$$
E T P=P+I-C
$$

Sendo:

$$
\begin{aligned}
& \text { ETP: evapotranspiração potenciao (mm/dia) } \\
& \text { P: precipitação (mm/dia) } \\
& \text { I: Irrigação (mm/dia) } \\
& \text { C: água percolada (mm/dia) }
\end{aligned}
$$

A equação de balanço hídrico estabelecida por Mota (1983) busca definir zonas climáticas ideais para as culturas e caracterizar as condições climáticas de uma região. E é descrita da seguinte forma: Precipitação + irrigação = umidade do solo + evapotranspiração + percolação + deflúvio superficial.

$$
P+I=U+E T P+C+D s
$$

Como podemos perceber, para o cálculo do balanço hídrico existem vários métodos, porém no Brasil e nesse presente trabalho, o método utilizado foi criado em 1948 por Thornthwaite, no qual considera a água no solo disponível as comunidades vegetais desde a capacidade de campo até o ponto de murcha permamente, ou seja, a água na CAD. Ele utiliza como estimadores a precipitação e a evapotranspiração, onde a partir dos cálculos estimam a evapotranspiração potencial e real, como também o déficit e o excedente hídrico. Podendo através desses parâmetros definir épocas boas e ruins para o plantio de determinada cultura.

Os dados obtidos no INMET foram transferidos para o programa de computador Excel, no qual foram trabalhados e foram calculadas as médias das temperaturas e o somatório das chuvas do período estudado. Os dados foram divididos em meses totalizando $12 \mathrm{em}$ um ano e foram dispostos em Figuras para melhor visualização dos resultados. 


\section{RESULTADOS E DISCUSSÃO}

Os resultados do balanço hídrico mensal com suas principais variáveis para todos os municípios analisados estão apresentados na Tabela 1 e em seguida serão apresentadas as Figuras relativas aos extratos do balanços hídricos e os balanços hídricos mensais correspondentes a cada município estudado, propiciando uma análise visual de quais são os meses mais propícios para produção agrícola em um ano de análise.

As principais variáveis que influencia no cálculo do balanço hídrico são a precipitação, a temperatura, a evapotranspiração real (ETR) e a evapotranspiração potencial (ETP), com os valores apresentados na Tabela 1:

De acordo com a Tabela 1, podemos perceber que o município que possui menores valores de Precipitação, ETP e ETR é o munícipio de Formosa e o que possui os maiores valores para a variável Precipitação é o município de Pirenópolis, enquanto os maiores valores para ETP e ETR ocorrem no município de Aragarças.

Tabela 1: Resultado da precipitação, ETR e ETP real e potencial para cada município.

\begin{tabular}{|c|c|c|c|c|c|c|c|c|c|}
\hline & & Aragarças| & Catalão & Formosa & Goiânia & Jataí & Mineiros & Pirenópolis & $\begin{array}{c}\text { Rio } \\
\text { Verde }\end{array}$ \\
\hline \multirow{2}{*}{ Precipitação } & média & 135.1 & 123.7 & 120.7 & 131 & 137.46 & 131.4 & 147.7 & 138.6 \\
\hline & total & 1620.6 & 1484.7 & 1447.9 & 1571.4 & 1649.5 & 1576.2 & 1772.3 & 1663.3 \\
\hline \multirow{2}{*}{ ETP } & média & 114 & 87.51 & 84.89 & 96.83 & 89.82 & 91.54 & 91.22 & 91.32 \\
\hline & total & 1367.95 & 1052.48 & 1018.64 & 1162 & 1077.82 & 1098.56 & 1094.59 & 1095.86 \\
\hline \multirow{2}{*}{ ETR } & média & 90.4 & 73.9 & 69.5 & 79.61 & 83.4 & 83.8 & 77.4 & 80.8 \\
\hline & total & 1084.2 & 886.8 & 834.5 & 955.7 & 1001 & 1005.2 & 929 & 969.9 \\
\hline
\end{tabular}

Na Figura 1 são apresentados o extrato do balanço hídrico e o balanço hídrico normal mensal para o município de Aragaças. A região se caracterizou com precipitação média mensal de 135,1 mm/mês, totalizando 1620,6 $\mathrm{mm}$ ao ano, onde a maioria das chuvas se concentra no mês de dezembro, janeiro fevereiro e março representando cerca de $64,9 \%$ do total de chuvas no ano (1053,3 mm). A maior precipitação média ocorre em janeiro com 311,4 mm e a menor ocorre no mês de junho com 4,4 mm.

A evapotranspiração potencial anual calculada pelo método de Thornthwaite foi de 1367,95 mm/ano com uma média de $114 \mathrm{~mm}$, sendo os meses com maiores e menores evapotranspiração potencial outubro e julho (146,01 e 73,58 mm). Segundo Matos et al., (2015) e Passos et al. (2017) os elevados valores de ETP para esse munícipio pode ser um fator determinante para que o município apresentem a maior deficiência hídrica ao longo do ano entre no estado. 0 armazenamento de água no solo foi determinado pela capacidade de água disponível, onde se adotou o valor de $100 \mathrm{~mm}$. A evapotranspiração real apresentou um total médio anual de 1084,2 mm, com média mensal de 90,4 mm.

Figura 1: Extrato do Balanço e Balanço Hídrico Normal Mensal para o município de Aragarças-GO.
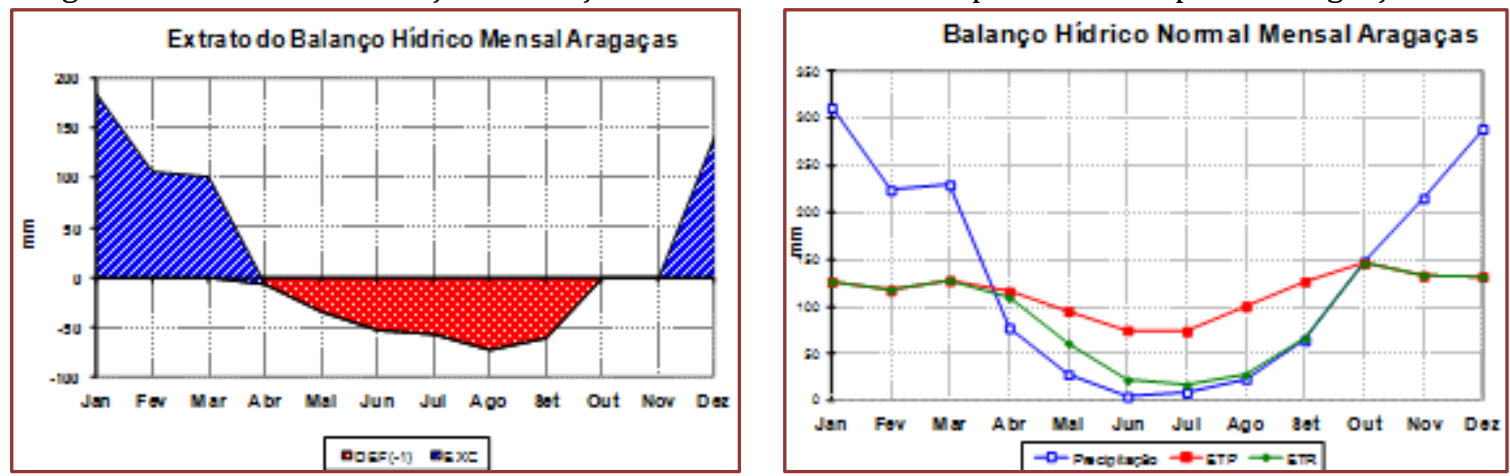
O resultado do extrato do balanço hídrico e o balanço hídrico normal mensal para a região de Catalão no estado de Goiás estão representados graficamente na figura 2. A região se caracterizou com uma precipitação média mensal de $123,7 \mathrm{~mm}$, totalizando $1484,7 \mathrm{~mm}$, concentrando - se nos meses de novembro, dezembro, janeiro e fevereiro. 0 total precipitado nesses meses correspondem a $65,27 \%$ $(969,1 \mathrm{~mm})$ do total precipitado no ano. Sendo a maior e a menor precipitação média com ocorrência nos meses de dezembro e junho (280,1 e 8,5 mm).

A evapotranspiração potencial anual foi de 1052,48 mm com média mensal de 87,71 mm. Sendo os meses com maiores e menores evapotranspiração potencial os de março $(103,97 \mathrm{~mm})$ e julho $(56,89 \mathrm{~mm})$. A evaportranspiração real apresentou um total médio anual de 886,8 mm com média mensal de 73,9 mm.

Figura 2: Extrato do Balanço e Balanço Hídrico Normal Mensal para o município de Catalão-GO.
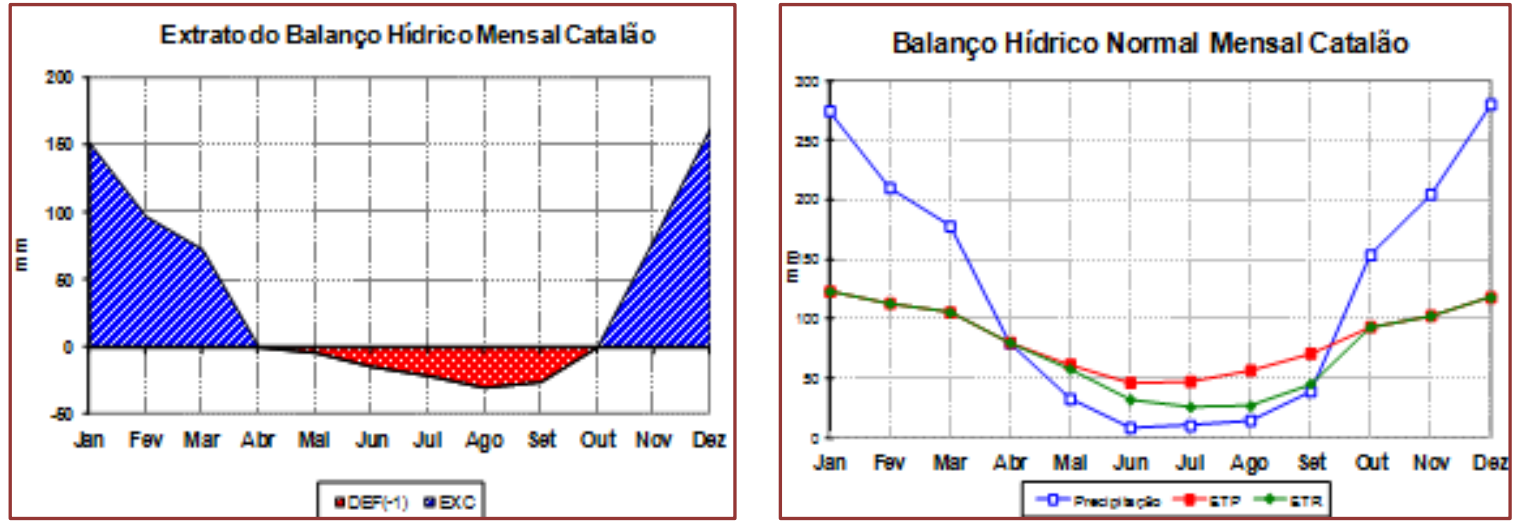

O resultado do extrato do balanço hídrico e o balanço hídrico normal mensal para a região de Formosa no estado de Goiás estão representados graficamente na Figura 3. A região se caracterizou com uma precipitação média mensal de $120,7 \mathrm{~mm}$, totalizando $1447,9 \mathrm{~mm}$, concentrando -se nos meses de novembro, dezembro, janeiro e fevereiro. 0 total precipitado nesses meses correspondem a 64,78\% (938 $\mathrm{mm}$ ) do total precipitado no ano. Sendo a maior e a menor precipitação média com ocorrência nos meses de dezembro e junho (300,1 e 2,6 mm).

A evapotranspiração potencial anual foi de 1018,64 mm com média mensal de $84,89 \mathrm{~mm}$. Sendo os meses com maiores e menores evapotranspiração potencial os de outubro $(99,64 \mathrm{~mm})$ e junho $(59,75 \mathrm{~mm})$. A evapotranspiração real apresentou um total médio anual de 834,5 mm com média mensal de 69,5 mm.

Figura 3: Extrato do Balanço e Balanço Hídrico Normal Mensal município de Formosa-GO.
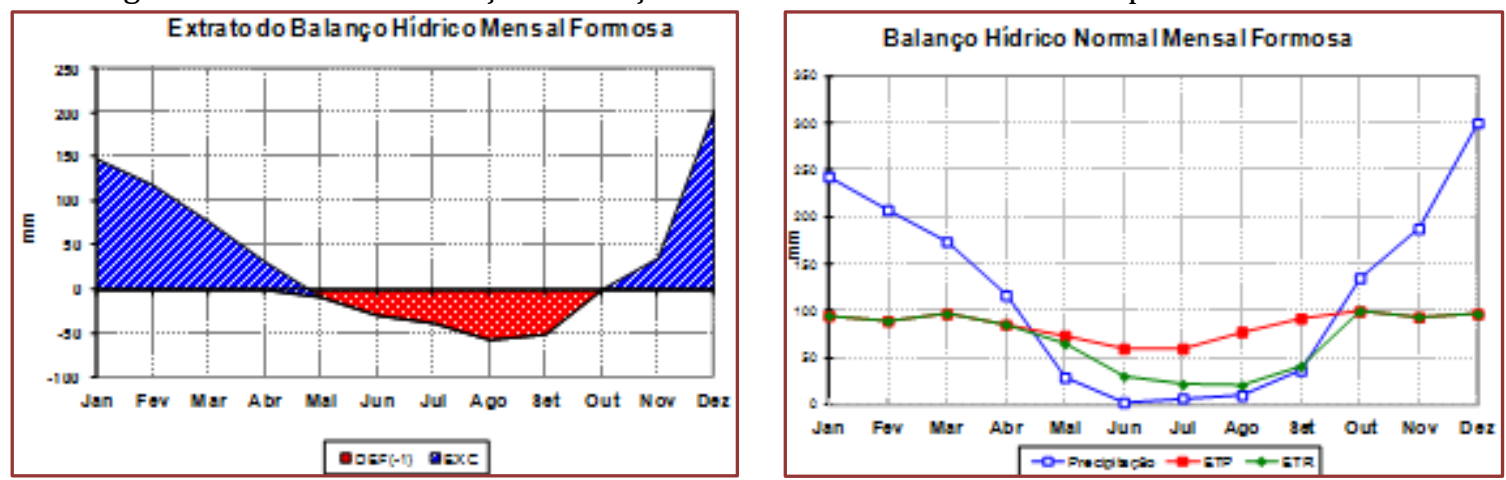
O resultado do extrato do balanço hídrico e o balanço hídrico normal mensal para a região de Goiânia no estado de Goiás estão representados graficamente na figura 4. A região se caracterizou com uma precipitação média mensal de $131,0 \mathrm{~mm}$, totalizando $1571,4 \mathrm{~mm}$, concentrando -se nos meses de novembro, dezembro, janeiro e fevereiro. 0 total precipitado nesses meses correspondem a $61,63 \%$ (968,5 mm) do total precipitado no ano. Sendo a maior e a menor precipitação média com ocorrência nos meses de dezembro e julho (267,9 e 6,6 mm).

A evapotranspiração potencial anual ETP foi de 1162,0 mm com média mensal de 96,83 mm. Sendo os meses com maiores e menores evapotranspiração potencial os de novembro $(109,78 \mathrm{~mm})$ e junho $(65,47$ $\mathrm{mm}$ ). A ETR apresentou um total médio anual de 955,7 mm com média mensal de 79,6 mm.

Figura 4: Extrato do Balanço e Balanço Hídrico Normal Mensal município de Goiânia-GO.
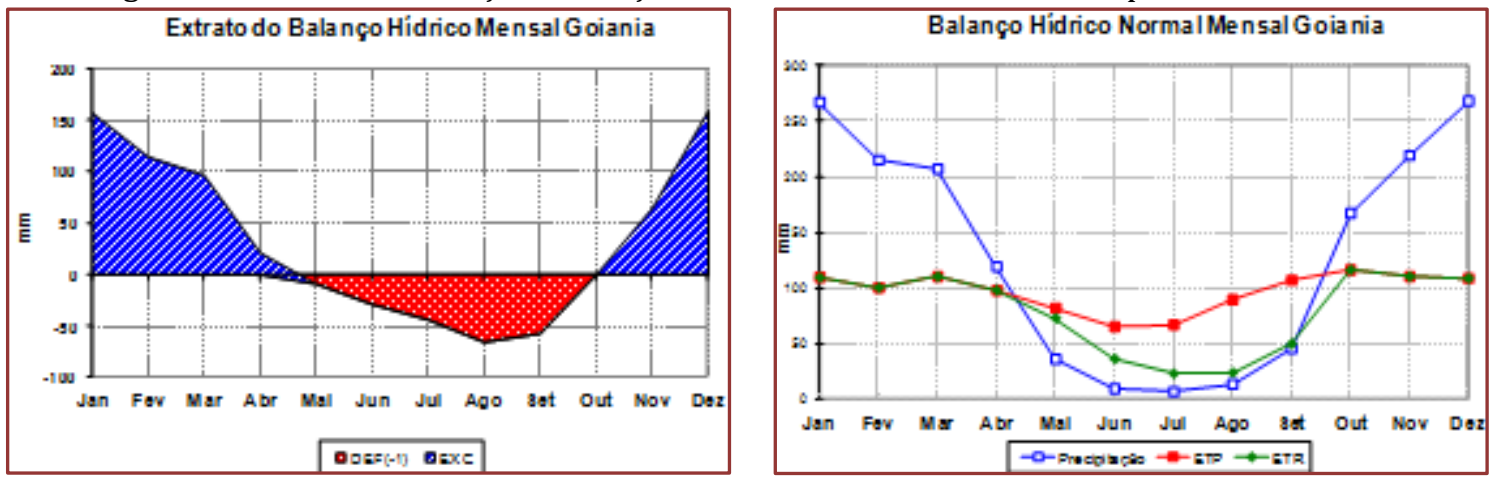

0 resultado do extrato do balanço hídrico e o balanço hídrico normal mensal para a região de Jataí no estado de Goiás estão representados graficamente na figura 5. A região se caracterizou com uma precipitação média mensal de 137,46 mm, totalizando 1649,5 mm, concentrando -se nos meses de dezembro, janeiro e fevereiro e março. 0 total precipitado nesses meses correspondem a 65,63\% (1082,6 $\mathrm{mm}$ ) do total precipitado no ano. Sendo a maior e a menor precipitação média com ocorrência nos meses de janeiro e julho (319,9 e 11,5 mm).

A evapotranspiração potencial anual foi de 1077,82 mm com média mensal de 89,82 mm. Sendo os meses com maiores e menores evapotranspiração potencial os de dezembro $(117,11 \mathrm{~mm})$ e junho $(47,96 \mathrm{~mm})$. A evapotranspiração real apresentou um total médio anual de 1001,0 mm com média mensal de 83,4 mm.

Figura 5: Extrato do Balanço e Balanço Hídrico Normal Mensal para o município de Jataí - GO.
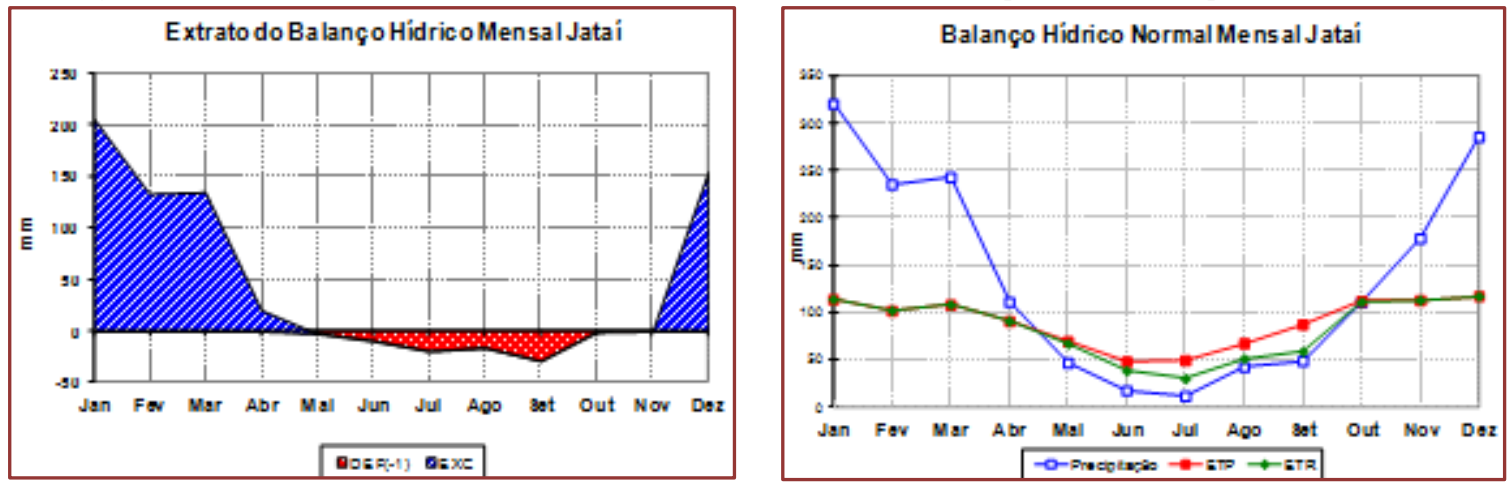
O resultado do extrato do balanço hídrico e o balanço hídrico normal mensal para a região de Mineiros no estado de Goiás estão representados graficamente na figura 6. A região se caracterizou com uma precipitação média mensal de 131,4 mm, totalizando $1576,2 \mathrm{~mm}$, concentrando -se nos meses de novembro, dezembro, janeiro e fevereiro. 0 total precipitado nesses meses correspondem a 59,09\% (931,5 mm) do total precipitado no ano. Sendo a maior e a menor precipitação média com ocorrência nos meses de janeiro e julho (305,2 e 14,7 mm).

A evapotranspiração potencial anual foi de 1098,46 mm com média mensal de 91,54 mm. Sendo os meses com maiores e menores evapotranspiração potencial os de dezembro $(112,41 \mathrm{~mm})$ e junho $(55,29 \mathrm{~mm})$. A evapotranspiração real apresentou um total médio anual de 1005,2 mm com média mensal de 83,8 mm.

Figura 6: Extrato do Balanço e Balanço Hídrico Normal Mensal para o município de Mineiros - GO.
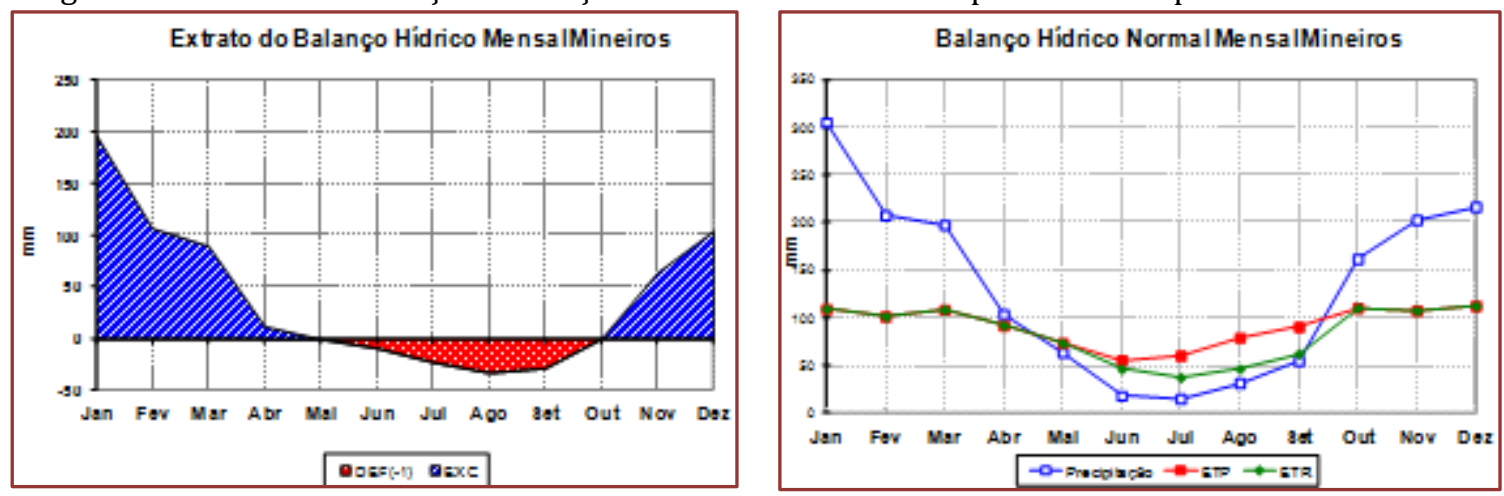

O resultado do extrato do balanço hídrico e o balanço hídrico normal mensal para a região de Pirenópolis no estado de Goiás estão representados graficamente na figura 7. A região se caracterizou com uma precipitação média mensal de $147,7 \mathrm{~mm}$, totalizando $1772,3 \mathrm{~mm}$, concentrando -se nos meses de novembro, dezembro, janeiro e fevereiro. 0 total precipitado nesses meses correspondem a 65,20\% $(1155,7 \mathrm{~mm})$ do total precipitado no ano. Sendo a maior e a menor precipitação média com ocorrência nos meses de dezembro e agosto (338,3 e 11,0 mm).

A evapotranspiração potencial anual foi de 1094,59 mm com média mensal de 91,22 mm. Sendo os meses com maiores e menores evapotranspiração potencial os de outubro (109,95 mm) e junho (61,96 mm). A evapotranspiração real apresentou um total médio anual de 929,0 mm com média mensal de 77,4 mm.

Figura 7: Extrato do Balanço e Balanço Hídrico Normal Mensal para o município de Pirenópolis - GO.
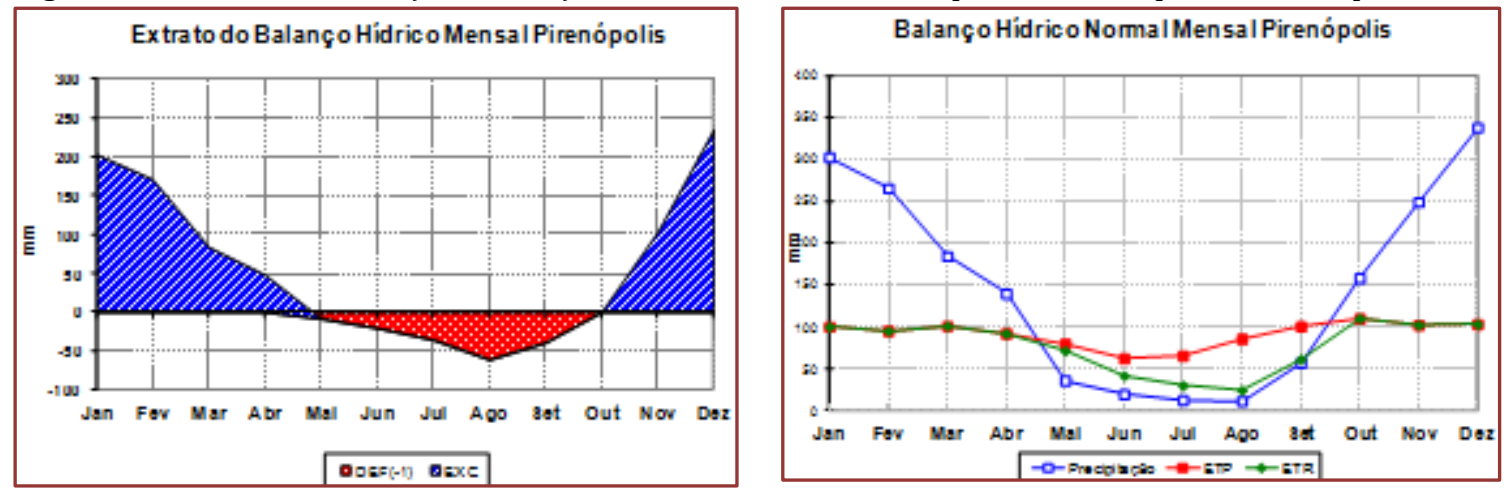
O resultado do extrato do balanço hídrico e o balanço hídrico normal mensal para a região de Rio Vede no estado de Goiás estão representados graficamente na figura 8. A região se caracterizou com uma precipitação média mensal de 138,6 mm, totalizando 1663,3 mm, concentrando -se nos meses de novembro, dezembro, janeiro e fevereiro. 0 total precipitado nesses meses correspondem a 60,06\% $(999,1 \mathrm{~mm})$ do total precipitado no ano. Sendo a maior e a menor precipitação média com ocorrência nos meses de dezembro e junho (278,3 e 13,4 mm).

A evapotranspiração potencial anual foi de 1095,86 mm com média mensal de 91,32 mm. Sendo os meses com maiores e menores evapotranspiração potencial os de outubro (111,36 mm) e junho (62,15 mm). A evapotranspiração real apresentou um total médio anual de 969,9 mm com média mensal de 80,8 mm.

Figura 8: Extrato do Balanço e Balanço Hídrico Normal Mensal para o municipio de Rio Verde - GO.
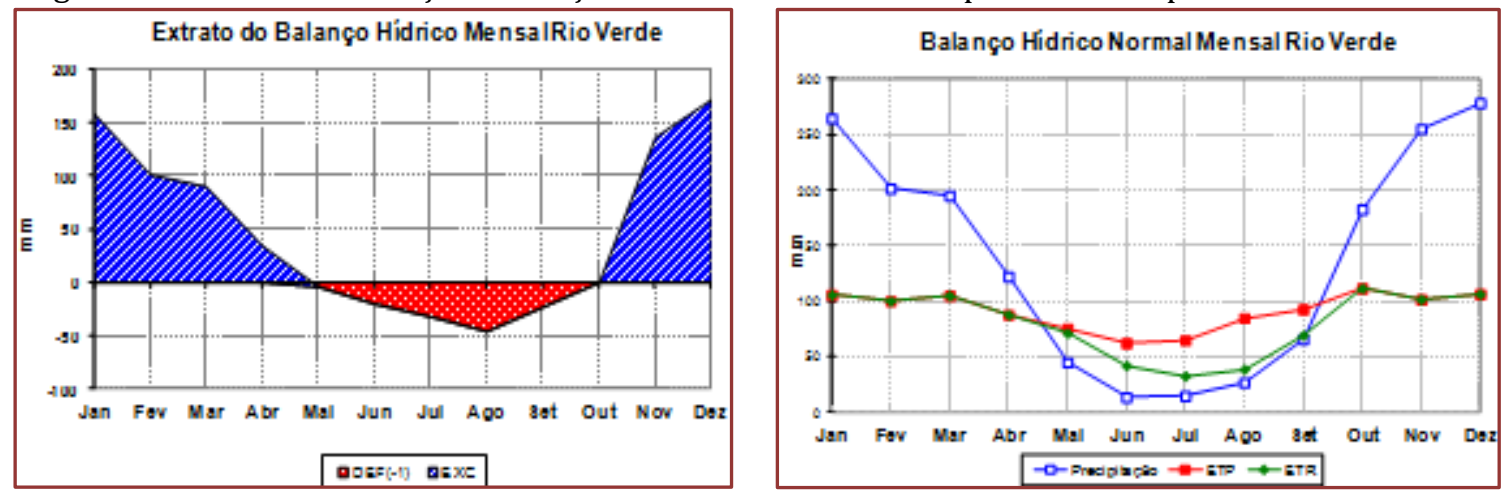

A partir dos balanços hídricos climatologicos e dos extratos dos balanços para os diversos municípios estudados pode se afirmar que, para todos os municípios, a estação seca e a estação chuvosa têm divisões similares ao longo do ano. Sendo a estação de déficit hídrico, representada em vermelho nos extratos dos balanços hídricos, ocorrendo do mês de maio ao mês de outubro e novembro, a depender da região estudada. A estação de excedente hídrico se encontra nos meses de janeiro a abril e de novembro a dezembro, sendo que a intensidade tanto do déficit quanto do excedente dependente do município analisado.

As variações pluviométricas totais mensais e anuais das chuvas são decorrentes do comportamento da circulação atmosférica regional ao longo do ano, em conjunto com fatores geoclimaticos locais ou regionais (PEREIRA et al.,2002). A posição geográfica, associada a fatores climáticos, geológicos, pedológicos, fitoecológicos, geomorfológicos e hídricos condicionam a variação dos balanços hídricos climatológicos para cada município. Graças ao histório socieconomico de cada região, como também a aplicação e acesso às políticas públicas, a ocupação do solo de cada município se faz diferente, trazendo um fator de variação entre os municípios que pode explicar algumas diferenças entre os Balanços Hídricos analisados, pois estes alteram a resposta do meio ambiente quanto a algumas variáveis climáticas.

Os municípios em análise se diferem muito pouco quanto a distribuição de chuvas e do período de seca no ano, podendo ser caracterizados como um clima tropical com temperaturas elevadas e com a déficit hídrico no inverno, ou seja, estação seca acontecendo durante o inverno, podendo ser classificado de acordo com a Classificação Climática de Koppen como Aw, ou seja, Clima Tropical com Estação seca de Inverno.

As metodologias para definição das classificações climáticas e BHC podem ser consideradas como critérios muito apropriados para definir as características climáticas do local se utilizando de valores médios mensais normais se fazem bons indicativos da tendência climática da região (SOUZA et al., 2013). Ressaltase também, que o BHC proposto por Thornthwaite; Mather (1955) pode ser utilizado para o acompanhamento do armazenamento de água no solo em tempo real, isto é, este balanço, deixa, então, de ser cíclico e passa a representar sequencialmente os valores de entradas e saídas no sistema solo-plantaatmosfera. 
Para fins agrometeorológicos, os balanços hídricos seqüenciais são importantes para definições de períodos para plantio, mecanização, colheita, pulverizações, manejo da irrigação, dentre outros (SANTOS et al., 2013).

De acordo com Santos et al., 2010, através do balanço hídrico mensal, pode se determinar um planejamento integrado dos recursos hídricos da região, que inclui a decisão pela aquisição de sistemas de irrigação e o dimensionamento da lâmina líquida do sistema, em que o irrigante considerando aspectos econômicos deve decidir entre a maior necessidade ou pelo maior déficit, além permitir o manejo da irrigação (quanto e quando irrigar) com base em dados históricos de evapotranspiração.

\section{CONCLUSÕES}

Os oito municípios do estado de Goias avaliados nesse estudo posuem duas estações climáticas bem definidas, uma chuvosa de outubro/novembro a abril e outra seca, de maio a setembro/outubro. As precipitações totais anuais variam de aproximadamente 1772,3 e 1447,9 mm por ano, representando o maior número em Pirenópolis e o menor em Formosa.

Aragaças foi o município que apresentou o maior déficit hídrico e o município de Formosa apresentou menor déficit hídrico.

O município que possui a maior parte das suas chuvas concentrada no período de excedente hídrico é o município de Jataí, com 65,63\% das suas chuvas concentradas de novembro a abril. 0 município que possui a menor parte das suas chuvas concentradas nesses meses é o município de Mineiros com 59,09\% de suas chuvas nos meses assinalados.

\section{REFERÊNCIAS}

[1] Allen, R. G.; Pereira, L. S.; Raes, D.; Smith, M. Crop evapotranspiration - Guidelines for computing crop water requirements. Roma: FAO Irrigation and Drainage, Paper 56, 1998. 297p

[2] Antunes, D. A.; Cupolillo, F. Balanço Hídrico Climatológico: Estudo de Caso do Município de Governador Valadares-MG. 2012. 22 f. Monografia. Instituto Federal Minas Gerais, Governador Valadares - MG, 2012.

[3] De Jesus, J. B. Estimativa do balanço hídrico climatológico e classificação climática pelo método de Thornthwaite e Mather para o município de Aracaju-SE. Scientia Plena, v. 11, n. 5, 2015.

[4] Lima, F. B.; Santos, G. O. Balanço hídrico-espacial da cultura para o uso e ocupação atual da bacia hidrográfica do Ribeirão Santa Rita, Noroeste do Estado de São Paulo. 2009. 89 f. Monografia. Fundação Educacional de Fernandópolis, Fernandópolis - SP, 2009.

[5] Matos, R. M., Silva, P. F., Medeiros, R. M., Borges, V. E., Lima, S.C. Estimativa do balanço hídrico climatológico e decadal para o município de Barbalha - CE. In: III Inovagri International Meeting, 2015. Disponível em: http://dx.doi.org/10.12702/iii.inovagri.2015-a004. Acesso em set 2019.

[6] Passos, M. L. V., Zambrzycki, G. C., Pereira, R. S. Balanço hídrico climatológico e classificação climática para o município de Balsas-Ma. Scientia Agraria, v. 18, n. 1, p. 83-89, 2017.

[7] Pereira, A. R. et al. Agrometeorologia: fundamentos e aplicações práticas. Guaíba: Agropecuária, 2002. 478 p.

[8] Santos, G. O., Hernandez, F. B. T., \& Rossetti, J. C. Balanço hídrico como ferramenta ao planejamento agropecuário para a região de Marinópolis, noroeste do estado de São Paulo. Revista Brasileira de Agricultura Irrigada-RBAI, v. 4, n. 3, 2010.

[9] Santos, R. B., de Souza, A. P., Silva, A. C., de Almeida, F. T., Arantes, K. R., \& de Siqueira, J. L. Planejamento da pulverização de fungicidas em função das variáveis meteorológicas na região de Sinop - MT. Global Science and Technology, Rio Verde, v.6, n.1, p.72-88, jan./abr. 2013

[10] Souza, A. P., Mota, L. L., Zamadei, T., Martin, C. C., Almeida, F. T., \& Paulino, J. Classificação climática e balanço hídrico climatológico no estado de Mato Grosso. Nativa, v. 1, n. 1, p. 34-43, 2013.

[11] Thornthwaite, C.W.; Mather, J.R. The water balance. Centerton, NJ: Drexel Institute of Technology Laboratory of Climatology, 1955. 104p. (Publications in Climatology, vol. VIII, n.1).

[12] Tubelis, A. \& Nascimento, F. J. L. do, 1986, Meteorologia descritiva. Nobel, São Paulo, 373p. 


\section{Capítulo 2}

Produtividade da água do feijoeiro comum irrigado

\section{Chaiane Guerra da Conceição}

\section{Adroaldo Dias Robaina}

Marcia Xavier Peiter

João Antônio da Conceição

Ana Rita Costenaro Parizi

Ana Carla dos Santos Gomes

Resumo: 0 objetivo do trabalho foi avaliar a produtividade da água na produção de grãos do feijoeiro comum irrigado. 0 estudo foi realizado no ano de 2016, no município de Alegrete - RS, e conduzido em casa de vegetação. 0 delineamento experimental utilizado foi inteiramente casualizado, com cinco tratamentos de irrigação $(0,25,50,75$, 100 e $125 \%$ da ETc) e quatro repetições. Foram analisados ao fim do experimento os parâmetros de produção da cultura e posteriormente deu-se o estudo da produtividade da água. Os resultados obtidos mostram que produtividade da água decresce conforme o incremento das lâminas de irrigação.

Palavras-Chave: lâminas de irrigação, total de água aplicada, Phaseolus vulgaris L. 


\section{INTRODUÇÃO}

Atualmente chamada de produtividade de água, representa uma forma mais global de avaliar o uso da irrigação, não se restringindo apenas aos aspectos de manejo do sistema, mas considerando também as questões relativas ao retorno econômico do uso da irrigação, à preservação ambiental e ao uso racional da água (TAVARES et al., 2007).

Em termos de produção, a produtividade de água de irrigação, pode ser avaliada através da relação entre o aumento da produção em peso e o volume de água consumido (TAVARES, 2007). Segundo Doorenbos e Kassan (1979) a produtividade de água pelas culturas agrícolas depende, sobretudo, das condições físicas do solo, das condições atmosféricas, do estado nutricional das plantas, de fatores fisiológicos, da natureza genética e o seu estádio de desenvolvimento.

Doorenbos e Kassam (1994) estabelecem, para a cultura do feijoeiro, o valor da produtividade de água na produção de grãos com umidade de $10 \%$ da ordem de 3 a $6 \mathrm{~kg} \mathrm{~mm}^{-1}$.Valores superiores foram encontrados por Cunha et al. (2013), que obteve $8,72 \mathrm{~kg} \mathrm{~mm}^{-1}$ para este parâmetro com irrigação baseada pelo método de Penmann. Parizi (2007) observou que a maior produtividade de água não se deu no tratamento com maior disponibilidade hídrica, e sim naquele que apresentava $80 \%$ de reposição da ETc, obtendo valor de $0,97 \mathrm{~kg} \mathrm{~m}^{-3}$. Munoz-Perea et al. (2006) encontraram valores de produtividade da água de $10 \mathrm{~kg} \mathrm{ha}^{-1} \mathrm{~mm}^{-1}$. Santana(2008) relataram valores de produtividade de água variando de 2,66 a $10 \mathrm{~kg} \mathrm{ha}^{-1}$ $\mathrm{mm}^{-1}$ de acordo com a reposição de água no solo com e sem irrigação, e constataram que as maiores médias ocorreram quando a irrigação foi realizada com $40 \%$ da ETc.

\section{MATERIAL E MÉTODOS}

0 trabalho foi desenvolvido em casa de vegetação da Universidade Federal do Pampa - Campus Alegrete Rio Grande do Sul. O município de Alegrete apresenta coordenadas geográficas 2971'16" de latitude sul e 5552'61" de longitude oeste. O local se encontra a 121m acima do nível do mar, apresentando clima predominante subtropical, temperado quente, com estações bem definidas (Cfa Koppen).

O experimento foi realizado no ano agrícola 2015/16, abrangendo o período de fevereiro/2016 a maio/2016, em delineamento inteiramente casualizado, com cinco tratamento e quatro repetições. Para a condução do experimento, foram utilizados vinte vasos de material plástico, apresentando dimensões de $33 \mathrm{~cm}$ de diâmetro e $30 \mathrm{~cm}$ de altura, com capacidade para aproximadamente 20 litros, dispostos sobre uma bancada com $30 \mathrm{~cm}$ de distância do solo, divididos em cinco tratamentos de irrigação com quatro repetições cada.

Os vasos foram preenchidos com solo oriundo de um Argissolo Vermelho Distrófico arênico, unidade de mapeamento São Pedro (STRECK et al., 2008), coletado da área experimental do Instituto Federal de Educação, Ciência e Tecnologia Farroupilha - Campus Alegrete.

0 manejo de irrigação utilizado baseou-se no turno de rega pré-fixado, com intervalo de quatro dias entre as irrigações. As lâminas de irrigação aplicadas durante o ciclo da cultura foram efetuadas com base nos dados de evapotranspiração de referência e realizada através da expressão:

$$
\mathrm{ETc}=E T o . k c
$$

Onde:

ETc - evapotranspiração da cultura (mm);

ETo - evapotranspiração de referência (mm);

Kc - coeficiente de cultura.

Para os tratamentos de irrigação foram testadas cinco lâminas distintas, correspondendo a $25 \%$ (tratamento 01), 50\% (tratamento 02), 75\% (tratamento 03), 100\% (tratamento 04) e 125\% (tratamento 05) do valor da evapotranspiração da cultura (ETc). 
A água da irrigação era adicionada aos vasos de maneira uniforme com o auxílio de proveta plástica, onde o valor evaporado em milímetros era convertido para mililitros.

Quando as plantas atingiram a senescência e umidade própria para colheita, foram avaliados os componentes de produção: número de vagens planta-1 ${ }^{-1}$ número de grãos vagem ${ }^{-1}$ e peso médio do grão. Para a obtenção dos componentes de produção foram coletadas cinco plantas de cada repetição. As plantas foram separadas, colocadas em envelopes de papel, identificadas e secadas em estufa durante 72 horas a $65^{\circ} \mathrm{C}$, e posteriormente realizadas as determinações.

Após a retirada das plantas da estufa foram contabilizados o número de vagens planta ${ }^{-1}$, debulhadas e contados os grãos vagem ${ }^{-1}$. 0 peso médio do grão foi obtido através da média da pesagem dos grãos planta $^{-1}$ de cada repetição para cada tratamento de irrigação.

A estimativa da produtividade ( $\left.\mathrm{kg} \mathrm{ha}^{-1}\right)$ foi obtida através da seguinte equação:

$$
\mathrm{Pg}=\frac{10}{0,01-U} \cdot N P L \cdot N V P \cdot N G V \cdot P M G
$$

Onde:

$$
\begin{aligned}
& \text { PG - produção de grãos }\left(\mathrm{kg} \mathrm{ha}^{-1}\right) ; \\
& \text { U - umidade dos grãos para colheita (13\%); } \\
& \text { NPL - número de plantas } \mathrm{m}^{-2} \text {; } \\
& \text { NVP - número de vagens plantas } \mathrm{m}^{-1} \text {; } \\
& \text { NGV - número de grãos vagem-1; } \\
& \text { PMG - peso médio do grão }(\mathrm{g}) \text {. }
\end{aligned}
$$

\section{RESULTADOS E DISCUSSÃO}

De acordo com a figura 1, é possível observar que a produtividade da água apresentou comportamento linear decrescente conforme o incremento das lâminas de irrigação, ou seja, o maior valor de $1,13 \mathrm{~kg} \mathrm{~m}^{-3}$ foi obtido pelo tratamento com menor reposição da lâmina (25\% da ETc), coincidindo ainda com a menor produção de grãos observada neste estudo.

FIGURA 1. Influência da água aplicada sobre a produtividade da água para a cultura do feijão

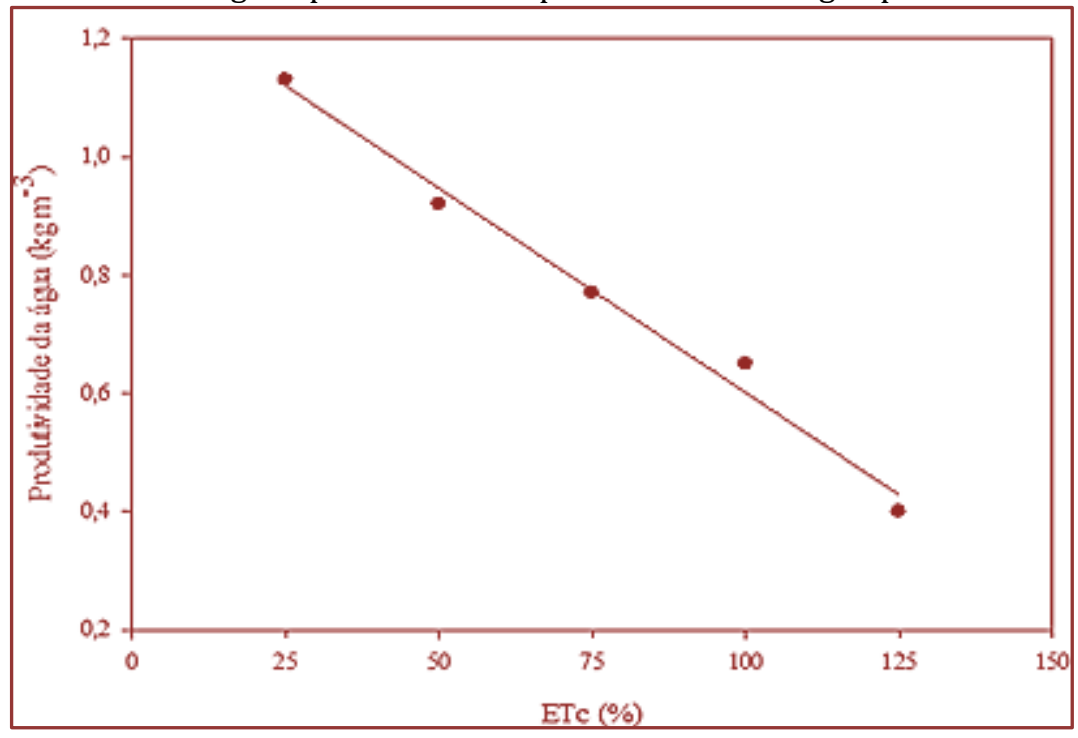


Isto indica que as lâminas de irrigação acima desse nível, visando a máxima produção de grãos, só deverão ser economicamente recomendadas quando a água não for um fator limitante ou então, apresentar baixo custo na produção agrícola. Os dados divergem com os indicados por Doorenbos e Kassam (1979), que estabeleceram, para a cultura do feijoeiro, o valor da produtividade da água na ordem de 0,3 a 0,6 $\mathrm{kg} \mathrm{m}^{-3}$ quando utilizado de 300 a $500 \mathrm{~mm}$ de água.

Porém, em trabalhos com diferentes manejos na irrigação do feijão (tensiometria, Tanque classe "A" e Penman-Monteith), Cunha et al. (2013), obtiverem média de PW de 0,88 $\mathrm{kg} \mathrm{m}^{-3}$, e explicam esse aumento principalmente ao fato do tipo de manejo de irrigação utilizado, de forma que alguns manejos propiciam suprimento de água bastante diferenciado.

Santana (2007) relata que o conceito produtividade da água é relativo, ou seja, maiores valores de PW não significam maior produtividade de grãos. 0 mesmo autor observou em seu estudo de irrigação e supressão de água, que obteve o maior valor de PW em torno de $1,0 \mathrm{~kg} \mathrm{~m}^{-3}$ quando aplicou a menor lâmina de reposição da ETc (40\%), onde obteve a menor produção de grãos de feijão.

TABELA 1. Análise de variância da produtividade da água para os diferentes tratamentos de irrigação.

\begin{tabular}{c|c|c|c|c|c|c|}
$\begin{array}{c}\text { Causas da } \\
\text { Variação }\end{array}$ & $\begin{array}{c}\text { Graus de } \\
\text { Liberdade (GL) }\end{array}$ & $\begin{array}{c}\text { Soma de } \\
\text { Quadrados } \\
\text { (SQ) }\end{array}$ & $\begin{array}{c}\text { Quadrado } \\
\text { Médio (QM) }\end{array}$ & $\begin{array}{c}\text { F Calculado } \\
\text { (Fc) }\end{array}$ & Pr>Fc & CV \% \\
\hline Irrigação & 4 & 1,365320 & 0,341330 & 19,219 & $0,0000^{*}$ & 15,97 \\
\hline Erro & 12 & 0,213120 & 0,017760 & & & \\
\hline Total corrigido & 19 & 1,626295 & & & & \\
\hline Média geral & 0,83 & & & & \\
\hline
\end{tabular}

\section{CONCLUSÕES}

É possível observar que a produtividade da água decresce, de forma linear, conforme o incremento das lâminas de irrigação, sendo o maior valor encontrado na menor lâmina de água aplicada (25\%), e o menor valor na maior lâmina de água (125\%), rexpectivamente.

\section{REFERÊNCIAS}

[1] Cunha, P. C. R. et al. Manejo da irrigação no feijoeiro cultivado em plantio direto. Revista Brasileira de Engenharia Agrícola e Ambiental. Campina Grande, PB. v.17, n.7, p.735-742, 2013.

[2] Doorenbos, J. \& Kassan, A.H. Yield response to water. FAO. Irrigation and Drainage.Paper 33, 1979, 193p.

[3] Doorenbos, J.; Kassan, A. H. Efeito da água no rendimento das culturas. Campina Grande: UFPB, 1994, 306p. Estudos FAO: Irrigação e Drenagem, 33.

[4] Muñoz-Perea, C. G.et al. Selection for drought resistance in dry bean landraces and cultivars. Crop Science, v.46, p.2111-2120, 2006.

[5] Parizi, A. C. Efeito de diferentes estratégias de irrigação sob as culturas de feijão (Phaseolus vulgaris L.) e milho (Zea mays L.) na região de Santiago, RS. 2007. 125f. Dissertação (Mestrado em Engenharia Agrícola) Universidade Federal de Santa Maria, Santa Maria, 2007.

[6] Santana, M.J.et al. Coeficiente de cultura e análise do rendimento do feijoeiro sob regime de irrigação. Irriga, Botucatu, v.13, n.1, p.92-112, 2008.

[7] Streck, E. V. et al. Solos do Rio Grande do Sul. 2.ed. Porto Alegre: Emater/RS, 2008. 222p.

[8] Tavares, V. E. Q. Sistemas de irrigação e manejo de água na produção de sementes. Pelotas, RS, 2007. 182p. Tese (Doutorado em Ciência e Tecnologia de Sementes) - Universidade Federal de Pelotas, Pelotas, 2007. 


\section{Capítulo 3}

\section{Teor de água do solo sob diferentes plantas de}

cobertura e preparo do solo em área de cana-de-açúcar

\section{Maria Cecilia Vieira Totti \\ Zigomar Menezes de Souza \\ Ingrid Nehmi de Oliveira \\ Camila Vieira Viana Farhate \\ Lenon Henrique Lovera \\ Elizeu Souza Lima}

Resumo: Este trabalho foi apresentado no XLVIII Congresso Brasileiro de Engenharia Agrícola - CONBEA 2019, em 17 a 19 de setembro de 2019 - Campinas - SP, Brasil. A cana-de-açúcar necessita de um grande volume de água para sua produção, com isso, é importante avaliar diferentes plantas de cobertura que mantenham a umidade no solo. Assim, o objetivo deste trabalho foi avaliar os teores de água no solo induzidos pelas plantas de cobertura amendoim e milheto no sistema de preparo de solo com cultivo mínimo e subsolagem profunda e compará-lo com o tratamento testemunha (sem planta de cobertura e plantio convencional) em área de cana-de-açúcar. 0 estudo foi conduzido em faixas, na usina Santa Fé, no município de Ibitinga, SP, Brasil. Foram avaliados a precipitação na área, a água em profundidade nos períodos seco e úmido durante o ciclo da cana-planta. Para a camada superficial ocorreu efeito dos preparos e das plantas de cobertura no teor de água no solo, com maior teor de água para o tratamento com cultivo mínimo, subsolagem profunda e milheto. Enquanto na camada subsuperficial os tratamentos obtiveram comportamentos semelhantes, por não sofreram efeitos significativos das plantas de cobertura.

Palavras-Chave: Milheto, amendoim, subsolagem profunda, umidade do solo. 


\section{INTRODUÇÃO}

O Brasil é um dos países mais adequados para a produção da cana-de-açúcar e seus derivados, visto que possuem condições edafoclimáticas propícias, características agronômicas das áreas de produção favoráveis aos altos rendimentos de sacarose, baixos custos de produção e tem vastas áreas que podem ser exploradas para o cultivo da cultura (LEAL et al., 2017)

Com o avanço tecnológico em busca de ganhos de eficiência e produtividade, viabilizou-se perfis de sistemas de produção capazes de dispensar a mão de obra nos processos de plantio, corte e carregamento (VISCHI FILHO et al., 2017), com isso, a cana-de-açúcar deixou de ser queimada para ser colhida mecanicamente, contudo, não houve grandes mudanças no preparo de solo, o preparo convencional continua prevalecendo nos canaviais. Com o tráfego de máquinas da colheita mecanizada, aumenta a preocupação com a compactação do solo e seus efeitos nos atributos físicos do solo (VASCONCELOS et al., 2012). Porém, é possível reduzir a compactação com manejo de solo, reduzindo às alterações físicohídricas do solo (RAWLS et al., 1996), e influenciando na forma do solo reter e absorver a água, afetando o seu comportamento hídrico (PANACHUKI et al., 2011).

Assim, conhecer a sua necessidade hídrica e aperfeiçoar a eficiência do manejo podem trazer benefícios na produção. Pesquisas relacionam a influência das plantas de cobertura (CARVALHO et al., 2015) e os diferente preparos do solo (ALMEIDA et al., 2018) com a infiltração de água, contudo em áreas de cana-deaçúcar esses estudos são poucos, porém, necessários para garantir melhor produção e qualidade do solo.

Neste sentido, o objetivo deste trabalho foi avaliar os teores de água no solo induzidos por diferentes plantas de cobertura (amendoim e milheto) sob o preparo de solo com cultivo mínimo e subsolagem profunda e compará-lo com o tratamento testemunha (sem planta de cobertura e preparo convencional).

\section{MATERIAL E MÉTODOS}

O estudo foi conduzido em condições de campo na usina Santa Fé, em uma área experimental no município

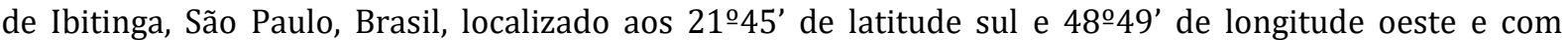
altitude média de 455 metros acima do nível do mar. A área é uma expansão do canavial da usina, sendo cultivada com pastagem anteriormente. 0 clima da região é classificado como tropical com estação seca (Aw) segundo a classificação climática de Köppen, com inverno frio e seco e verão quente e chuvoso. Na região ocorrem médias anuais de precipitação na ordem de $1.260 \mathrm{~mm}$ e a temperatura relativa média do ar é de 22,9 ํㅡ (CEPAGRI, 2015).

0 delineamento experimental ocorreu em faixas com esquema de parcelas subdivididas, em que as plantas de cobertura foram implantadas nas faixas horizontais, e os sistemas de preparo do solo, nas faixas verticais, com três repetições. Cada parcela foi composta por 6 linhas de cana-de-açúcar da variedade CTC 4, com espaçamento de 1,5 m e $30 \mathrm{~m}$ de comprimento, perfazendo uma área de $300 \mathrm{~m}^{2}$ por parcela.

O solo foi classificado como Argissolo Vermelho distrófico típico, segundo o Sistema Brasileiro de Classificação de Solos (EMBRAPA, 2013) ou como Ultisols Udults, segundo o Soil Taxonomy System (SOIL SURVEY STAFF, 2014). Foi identificado como horizonte diagnostico superficial, o horizonte A moderado e horizonte subsuperficial B textural, com relevo suave ondulado. Foi utilizado o sistema de preparo do solo com cultivo mínimo e subsolagem profunda (CM/SP), subsolagem a 0,70 m de profundidade. Foi implantado um tratamento testemunha, sem rotação de culturas e preparo do solo convencional (PC) que comumente é empregado nas usinas.

As avaliações do teor de água no solo foram realizadas mensalmente a partir do plantio da cana-planta utilizando o equipamento Diviner 2000 (Sentek Austrália), que consiste em um display com teclado coletor de dados (datalogger) acoplado via cabo a uma sonda. A frequência de leitura é armazenada pelo datalogger em um tempo fixo (1 s), resultando em leituras na faixa de $120.000 \mathrm{MHz}$ (água) e $160.000 \mathrm{MHz}$ (ar), dependendo da umidade do solo.

A temperatura e precipitação ocorridas na área foram monitoradas com uma estação meteorológica da marca Anova tecnologia, com configuração para medição a cada 5 minutos. 
A partir destes dados foi possível a avaliação das condições climáticas que a área experimental ficou submetida durante o período experimental. Foram testadas as médias com uma análise de variância (ANOVA) com o teste de Tukey para os diferentes tratamentos.

Figura 1. Plantas de cobertura; A- Amendoim, B- Milheto.
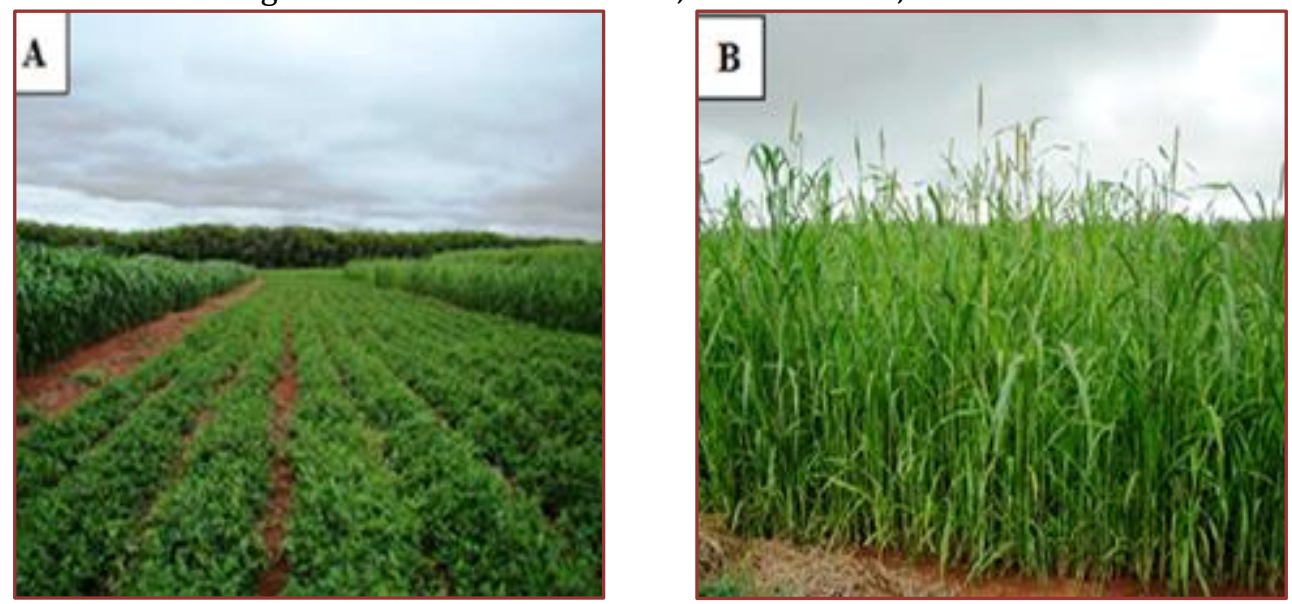

\section{RESULTADOS E DISCUSSÃO}

É possível verificar distribuição desuniforme entre as precipitações (Figura 1), que pode afetar o ciclo fenológico da cana devido a excessos e escassez em alguns momentos (SILVA et al., 2011). Para a canaplanta a Fase 1 sofreu um excesso de água enquanto a Fase 2 sofreu escassez. A precipitação anual não foi suficiente para alcançar o ideal de $1.710 \mathrm{~mm}$ por ano (SILVA et al., 2011), sendo apenas 3\% abaixo do esperado. De acordo com Machado et al. (2009), o estresse hídrico nas fases 2 e 3 causam problemas de crescimento de caule e alongamento das folhas, essencial para a fotossíntese da planta.

Houve um menor teor de água na camada superficial $(0,00-0,30 \mathrm{~m})$, e maior na subsuperficial $(0,30-0,70$ $\mathrm{m})$. She et al. (2014) avaliando o teor de água do solo até 1,00 m, verificaram que na camada superficial ocorreu menor teor de água comparado a camadas mais profundas, sendo que a distribuição de água ao longo da área pode estar relacionada a diversos fatores como preparo de solo, textura ou teor de carbono. Assim, o maior teor de areia causa maior ocorrência de macroporos fazendo com que haja maior absorção de água na camada mais argilosa inferior (0,30-0,70 m), devendo-se tomar cuidado para que não ocorram erosões da camada superficial em momentos de alta pluviosidade.

Figura 2. Precipitação na área experimantal e requerimento hídrico para cultura da cana-de-açúcar (SILVA et al., 2011) para dois ciclos avaliados.

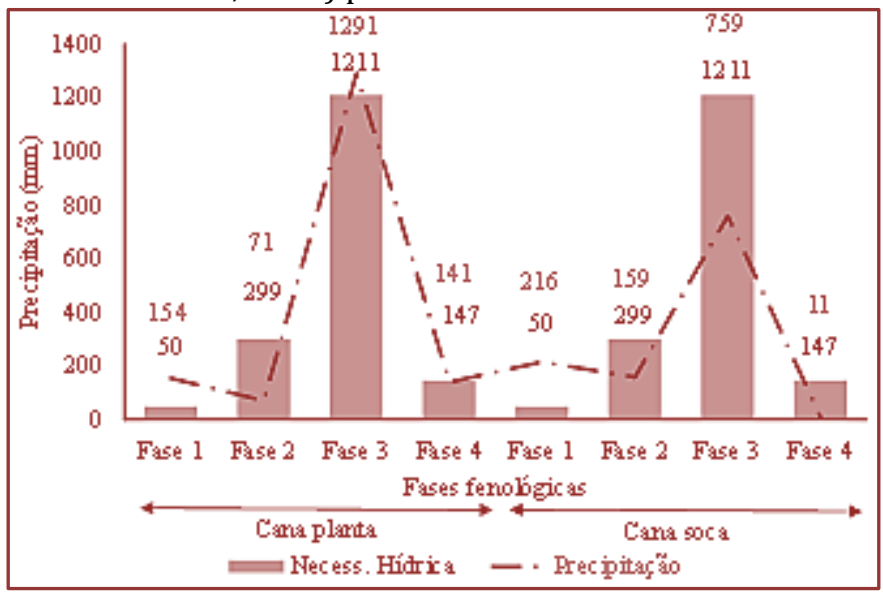


Além disto, para o período seco houve diferença significativa para as plantas de cobertura, onde a quantidade de palha gerada atuou de forma positiva proporcionando maiores teores de água do solo (Figura 2). Durante o período úmido esse efeito não foi tão significativo, pois os poros tendem a ficar saturados ocasionando, consequentemente, uma ausência de diferenças entre tratamentos, enquanto no período de estiagem a quantidade de palha, ao proteger o solo de incidências direta de raios solares, auxilia na manutenção de maiores teores de água no solo (PROSDOCIMI et al., 2016).

Figura 3. Valores de teor de água no solo (umidade volumétrica) e precipitação acúmulada na área utilizando as plantas de cobertura (amendoim e milheto) e preparo de solo com cultivo mínimo e subsolagem profunda (CM/SP) comparados ao tratamento testemunha, sem planta de cobertura e plantio convencional $(\mathrm{PC}) . \mathrm{A}=$ camada superficial $(0,00-0,30 \mathrm{~m}) ; \mathrm{B}=$ camada subsuperficial $(0,30-0,70 \mathrm{~m})$.
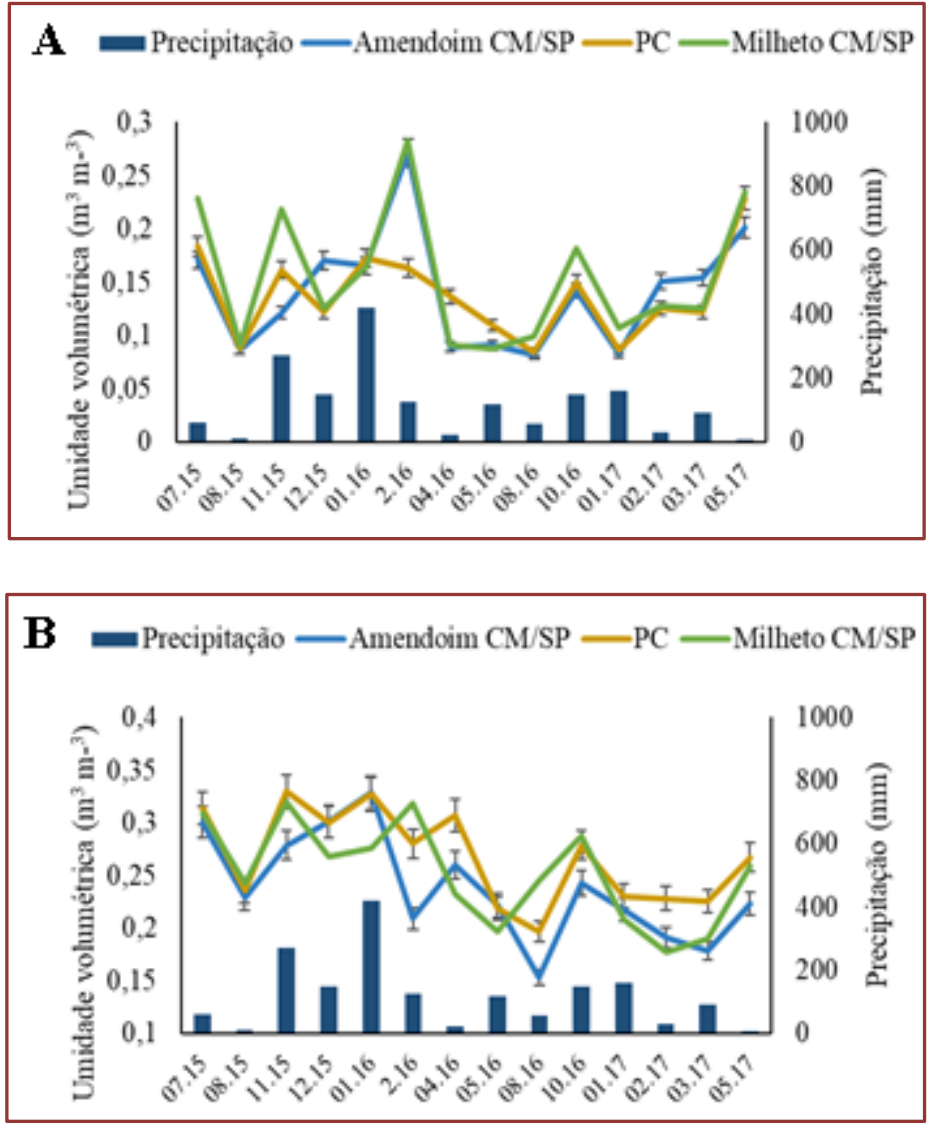

As barras de erro indicam que milheto obteve os maiores teores de água no solo em comparação a área que foi cultivada com amendoim, estando de acordo com os resultados obtidos por Ambrosano et al. (2014), os quais afirmam que plantas que produzem maior quantidade de massa seca influenciam diretamente na capacidade de proteção do solo, pois além de reduzir a incidência direta solar também reduz a amplitude térmica pela manutenção da temperatura do solo constante e aumenta o teor de água no solo.

Na camada subsuperficial $(0,30-0,70 \mathrm{~m})$ os tratamentos obtiveram comportamentos próximos, devido ao fato de terem mesma textura e não sofrerem efeitos significativos da planta de cobertura. Assim, nesta profundidade o preparo convencional, por apresentar menores efeitos do revolvimento do solo, se manteve mais próximo ao outro tratamento estudado, sendo que em alguns períodos até superior.

0 preparo convencional obteve maiores teores de água no solo em épocas secas, e se manteve acima do preparo com cultivo mínimo e subsolagem profunda. Gomes et al. (2014) estudando diferentes sistemas de manejo do solo com o cultivo do milho, verificaram que para camadas mais profundas as diferenças entre preparos conservacionistas e convencional são menores.

0 amendoim, pela sua baixa produção de biomassa seca e sistema radicular não obteve maiores teores de água do que o testemunha. Com isto, como resposta, observou-se que o teor de água no solo da camada subsuperficial sofreu menor influência das plantas de cobertura e maior do preparo do solo. 


\section{CONCLUSÕES}

Para a camada superficial ocorreu efeito dos preparos e das plantas de cobertura no teor de água no solo, com maior teor de água para o tratamento com cultivo mínimo e subsolagem profunda.

Na camada subsuperficial os tratamentos obtiveram comportamentos parecidos, por não sofreram efeitos significativos das plantas de cobertura.

\section{REFERÊNCIAS}

[1] Almeida, W. S.; Panachuki, E.; de Oliveira, P. T. S.; da Silva Menezes, R.; Sobrinho, T. A.; de Carvalho, D. F. Effect of soil tillage and vegetal cover on soil water infiltration. Soil and Tillage Research, v. 175, p. 130-138, 2018.

[2] Ambrosano, E. J.; Cantarella, H.; Ambrosano, G. M. B.; Schammas, E. A.; Dias, F. L. F.; Rossi, F.; Trivelin, P. C. O.; MURAOKA, T.; Azcón, R. Produtividade de cana-de-açúcar em ciclos agrícolas consecutivos após pré-cultivo de espécies adubos verdes. Revista de Agricultura, v.89, n.3, p.232-251, 2014.

[3] Carvalho, D. F.; Eduardo, E. N.; Almeida, W. S.; Santos, L. A. F.; Alves Sobrinho, T. Water erosion and soil water infiltration in different stages of corn development and tillage systems. Revista Brasileira de Engenharia Agrícola e Ambiental, v.19, n.11, p.1072-1078, 2015.

[4] Centro de Pesquisas Meteorológicas E Climáticas Aplicadas A Agricultura - CEPAGRI. Clima dos Municípios Paulistas.Campinas: CEPAGRI, 2015. Disponível em: <http://www.cpa.unicamp.br>.

[5] Embrapa - Empresa Brasileira de Pesquisa Agropecuária. Sistema Brasileiro de Classificação de Solos. 3 ed. Revisão Ampliada - Brasília, DF. 2013. p. 353.

[6] Gomes, R. L. R.; Silva, M. C.; Costa, F. R.; Lima Junior, F.; Oliveira, I. P.; Silva, D. B. Propriedades físicas e teor de matéria orgânica do solo sob diferentes coberturas vegetais. Revista Faculdade Montes Belos, v. 8, n. 5, p. 72-139, 2014.

[7] Leal, D. P. V.; Coelho, R. D.; Barbosa, F. da S.; Fraga Júnior, E. F.; Mauri, R.; Santos, L. da C. Water productivity for sugar and biomass of sugarcane varieties. Revista Brasileira de Engenharia Agrícola e Ambiental, Campina Grande, v.21, n.9, p.618-622, 2017.

[8] Machado, R. S.; Ribeiro, R. V.; Marchiori, P. E. R.; Machado, D. F. S. P.; Machado, E. C.; Landell, M. G. A. Respostas biométricas e fisiológicas ao déficit hídrico em cana-de-açúcar em diferentes fases fenológicas. Pesquisa Agropecuária Brasileira, v.44, n.12, p.1575-1582, 2009.

[9] Panachuki, E.; Bertol, I.; Sobrinho, T. A.; Oliveira, P. T. S.; rodrigues, D. B. B. Perdas de solo e de água e infiltração de água em Latossolo Vermelho sob sistemas de manejo. Revista Brasileira de Ciência do Solo, v.35, n.5, p.1777-1786, 2011.

[10] Prosdocimi, M.; Jordán, A.; Tarolli, P.; Keesstra, S.; Novara, A.; Cerdà, A. The immediate effectiveness of barley straw mulch in reducing soil erodibility and surface runoff generation in Mediterranean Vineyards. Science of The Total Environment, v.547, p.323-330, 2016.

[11] RAWLS, W. J.; David, G.; Van Mullen, J. A.; WARD, T. J. Infiltration. 2. Ed. New York: ASCE Manuals and Report on Engineering Practice, 1996.

[12] SHE, D.; TANG, S.; Shao, M.; YU, S.; XIA, Y. Characterizing scale specific depth persistence of soil water content along two landscape transects. Journal of Hydrology, v.519, p.1149-1161, 2014.

[13] Silva, T. G. F.; Moura, S. B.; Zolnier, S.; Soares, J. M.; Vieira, V. J. S.; Junior, W. G. F. Requerimento hídrico e coeficiente de cultura da cana-de-açúcar irrigada no semiárido brasileiro. Revista Brasileira de Engenharia Agrícola Ambiental, Campina Grande, v.16, n.1, p.64-71, 2011.

[14] Soil Survey Staff. Keys to soil taxonomy. Washington, DC: U.S. Dept. of Agriculture Natural Resources Conservation Service, 2014.

[15] Vasconcelos, R. F. B. de; Cantalice, J. R. B.; Moura, G. B. de A.; Rolim, M. M.; Montenegro, C. E.V. Compressibilidade de um Latossolo Amarelo distrocoeso não saturado sob diferentes sistemas de manejo da cana-deaçúcar. Revista Brasileira de Ciência do Solo, v.36, n.2, p.525-536, 2012.

[16] Vischi Filho, O. J.; Souza, Z. M. de; Souza, G. S. de; Silva, R. B. da; Torres, J. L. R.; LIMA, M. E. de. Physical attributes and limiting water range as soil quality indicators after mechanical harvesting of sugarcane. Australian Journal of Crop Science, Brisbaine, v.11, n.2, p.169-176, 2017. 


\section{Capítulo 4}

\section{Inativação de coliformes por lâmpadas ultravioletas submersas em águas residuárias}

\section{Gabriela de Luzia Barros Mesquita}

Fátima Resende Luiz Fia

Débora Ester Santos Fialho

Resumo: A elevada demanda de água para uso humano e industrial, associada à deterioração de corpos d'água pelo despejo de efluentes não tratados, tem promovido a busca constante por novas técnicas, viáveis e eficientes, de tratamento de águas residuárias, visando o desenvolvimento socioeconômico e a sustentabilidade ambiental. Nesse contexto, surge, como opção de tratamento terciário, a desinfecção de efluentes domésticos através de lâmpadas emissoras de radiação ultravioleta (UV). Trata-se de um tratamento físico aplicado como alternativa à cloração, já que não produz subprodutos tóxicos na água. Antecedendo a passagem do efluente pelo reator Ultravioleta, como uma alternativa para potencializar a desinfecção do efluente, tem-se o filtro lento de areia. Dessa forma, o estudo proposto objetivou avaliar a eficiência do uso de lâmpadas germicidas para a remoção de coliformes termotolerantes, bem como a determinação do melhor tempo de contato da lâmpada com o efluente, com e sem a passagem prévia do efluente pelo filtro lento de areia, sendo avaliadas duas taxas de aplicação superficial: de $150 \mathrm{~m} 3 \mathrm{~m} 2 \mathrm{~d}-1$ e de 7,2 m3 m2 d-1. A análise foi feita com uma única lâmpada de radiação ultravioleta (UV-C) germicida de $254 \mathrm{~nm}$, acoplada a um sistema que permitia a entrada do efluente sanitário da ETE avaliada por fluxo de batelada. Os tempos de contato avaliados foram de 10, 20, 30, 40 e 50 segundos. Os resultados revelaram que, para o efluente proposto, o melhor tempo de contato definido foi o de 50 segundos para coliformes termotolerantes, além disso, ao acoplar previamente o filtro de areia, a remoção foi maior para uma TAS de 7,2 m3 m2 d-1 e tempo de contato de 50 segundos, possibilitando uma inativação equivalente a 1,65 log. Através da abordagem experimental, concluiu-se que o sistema se mostrou eficiente para a remoção das variáveis estudadas, de tal forma que o efluente final está de acordo com os padrões estabelecidos pela legislação brasileira.

Palavras-chave: tratamento terciário, patógenos, radiação UV, esgoto sanitário, filtração lenta de areia. 


\section{INTRODUÇÃO}

A elevada demanda de água para uso doméstico, industrial e agrícola tem provocado o crescente aumento do consumo de água doce e, consequentemente, a elevada produção de águas residuárias. Assim, no cenário atual, a finalidade dos projetos de saneamento está progressivamente associada ao contexto ambiental, que busca promover não só a saúde humana, como também, a conservação do meio físico e biótico. Desse modo, percebe-se a importância das questões situadas na interface entre os recursos hídricos e o saneamento ambiental. Entre essas questões destacam-se o tratamento, a disposição e a gestão adequada de efluentes, visando conciliar o desenvolvimento econômico à sustentabilidade ambiental e à manutenção da saúde pública.

Diante disso, a preocupação tange no que diz respeito à descarga incorreta de efluentes nos cursos de água, afetando seus usos posteriores, poluindo o meio ambiente e prejudicando a saúde humana. De acordo com o Instituto Trata Brasil, no País, atualmente, 44,92\% do esgoto não é tratado, de forma que já são mais de 110 mil quilômetros de cursos de água pelo território nacional com qualidade comprometida pelo lançamento de efluentes sem tratamento (TRATA BRASIL, 2019). Como consequência da falta ou precariedade do saneamento, observa-se um elevado número de brasileiros acometidos por doenças de veiculação hídrica, uma vez que o contato humano com águas contaminadas é apontado como uma das principais fontes de disseminação de doenças. Em 2013, conforme o Ministério da Saúde (DATASUS, 2014) foram notificadas mais de 340 mil internações por infecções gastrointestinais no país. A fragilidade do sistema de saneamento brasileiro não afeta somente a saúde humana e a qualidade ambiental, como também a situação econômica. Ainda segundo o Instituto Trata Brasil (2019), a cada $R \$ 1,00$ investido em saneamento é gerada uma economia de $\mathrm{R} \$ 4,00$ reais na saúde. Logo, a análise desses dados permite concretizar a importância que a desinfecção de águas residuárias assume na conjuntura brasileira atual, constituindo uma solução eficaz para a problemática apresentada.

A desinfecção de águas residuárias por radiação ultravioleta é um tratamento físico terciário que visa à remoção de organismos patogênicos pelo contato do efluente com a lâmpada germicida. Tal tratamento apresenta como ideia principal a emissão de UV-C (uma das faixas de comprimento da radiação UV), associada ao comprimento de onda de $254 \mathrm{~nm}(472,3 \mathrm{~kJ} . m o l-1)$, para inativação de microrganismos, tornando-os debilitados para sobrevivência e inibindo sua reprodução (BILOTTA; DANIEL, 2012). A radiação UV é capaz de atravessar a parede celular dos microrganismos e romper sua estrutura de DNA ou RNA, de forma, muitas vezes, irreversível. Ao contrário da Cloração e Ozonização, que possuem elevado potencial para formação de subprodutos tóxicos (compostos halogenados - trihalometanos - e bromato, respectivamente), a desinfecção por radiação Ultravioleta não gera resíduos nocivos na água. Além disso, é de simples manutenção e instalação e requer baixo espaço físico para seu funcionamento. Entretanto, tal sistema de desinfecção apresenta um elevado custo operacional, motivo pelo qual ainda é uma técnica pouco explorada em estações de tratamento de esgoto brasileiras.

Com o intuito de potencializar a ação desinfetante do reator UV, tem-se como alternativa a passagem anterior do efluente por filtros de areia. 0 filtro de areia é um dos métodos de tratamento mais antigos conhecidos, elaborado a partir da analogia com a percolação de água através do solo. Fundamentado nesse mecanismo, foi desenvolvido o filtro de areia lento, constituído pela fonte de alimentação do efluente, por uma camada de leito filtrante de areia, sustentada por uma camada de pedregulhos e pelo sistema de drenagem. A filtração lenta de areia (SSF) é uma tecnologia simples, que engloba processos físicos, químicos e biológicos, envolvendo métodos de transporte, aderência e atividade biológica no meio filtrante.

Nessa perspectiva, o objetivo geral do presente trabalho foi realizar ensaios de desinfecção em um reator ultravioleta de bancada e determinar o melhor tempo de contato entre a lâmpada germicida e o efluente produzido na Universidade Federal de Lavras. Além disso, pretendeu-se também comparar a eficiência de desinfecção do efluente com e sem o acoplamento prévio do filtro de areia no sistema com a taxa de aplicação hidráulica utilizada na Estação de Tratamento de Efluentes da UFLA (ETE-UFLA) com demais taxas encontradas na literatura, a fim de verificar qual taxa aplicada proporciona a melhor remoção de microrganismos.

\section{METODOLOGIA}

\subsection{CARACTERIZAÇÃO ETE/UFLA}

A Universidade Federal de Lavras é uma instituição de ensino que atua na área de graduação e pósgraduação, nos ramos de pesquisa, extensão e ensino, em, praticamente, todas as áreas de conhecimento 
(UFLA,2016). Dentre as instalações presentes na UFLA, destaca-se, para este trabalho, a Estação de Tratamento de Esgotos (ETE/UFLA), localizada no Campus Universitário.

A Estação tem capacidade de receber $800 \mathrm{~m} 3 \mathrm{~d}-1$ de efluentes e combina processos físicos, químicos e biológicos para fazer o tratamento do efluente. A ETE/UFLA é composta por reatores anaeróbios do tipo UASB, seguidos de sistema aeróbio tipo FBAS (Filtro Biológico Aerado Submerso), tendo o filtro de areia e a cloração seguida de sistema de radiação ultravioleta para desinfecção. Durante a realização dos experimentos, os filtros de areia, bem como a cloração e a radiação ultravioleta, encontravam-se em manutenção. (FIALHO, 2018)

Figura 1 - Esquema de tratamento presente na ETE/UFLA.

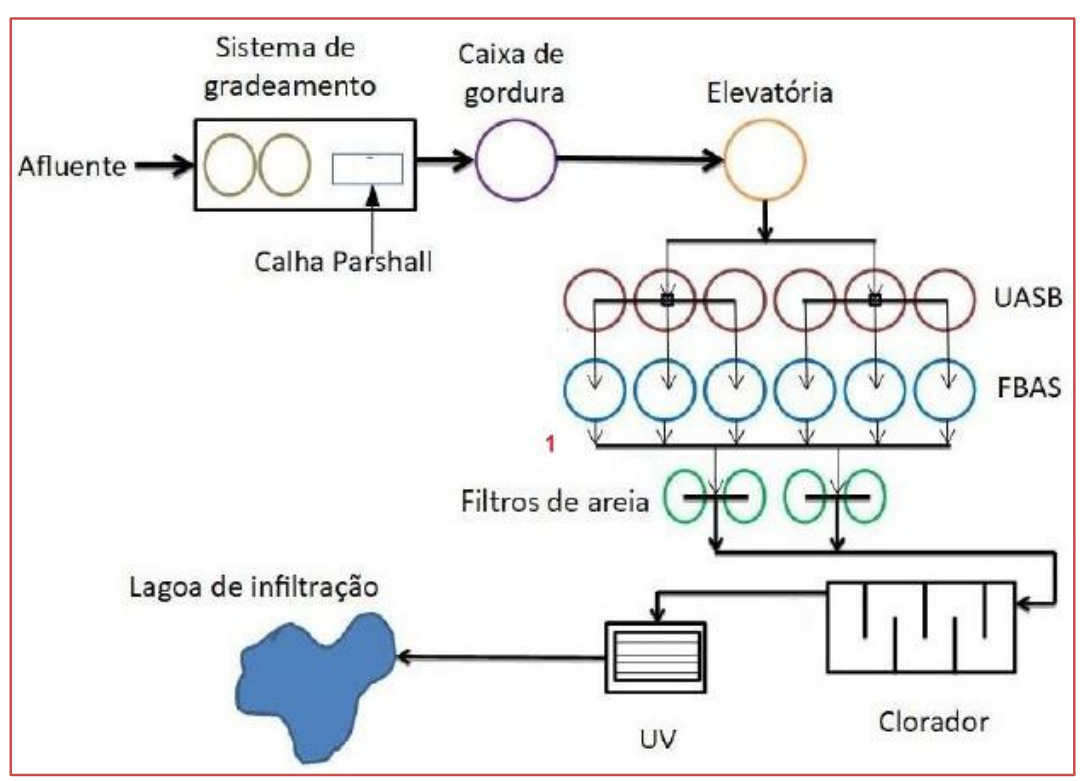

Fonte: adaptado de FIALHO, 2018

Assim, para o presente trabalho, os ensaios foram realizados com amostras coletadas depois da passagem do efluente pelo FBAS, no ponto 1, de acordo com a figura 1. Como o filtro de areia e a desinfecção ultravioleta estavam em manutenção, foram feitos reatores em escala de bancada simulando as condições de passagem do efluente pelas duas estruturas.Para simular as condições presentes na ETE/UFLA, levaram-se em consideração as dimensões e as configurações em escalas reais do filtro de areia e do reator de desinfecção UV da estação. Para tal, vale destacar que o filtro de areia possui comprimento de 1,55 m e área superficial de $2,4 \mathrm{~m}^{2}$, com capacidade de receber uma taxa de aplicação superficial (TAS) de $150 \mathrm{~m}^{3}$ $\mathrm{m}^{2} \mathrm{~d}-1$. Já a desinfecção UV é composta por um arranjo de 20 lâmpadas de $75 \mathrm{~W}$, cada qual revestida por um tubo de quartzo e disposta na horizontal, permitindo a entrada de fluxo contínuo.

\subsection{REATOR ULTRAVIOLETA}

Os ensaios experimentais de desinfecção por radiação ultravioleta foram realizados em um reator construído em escala de bancada. 0 reator foi produzido em PVC, com capacidade máxima de 7,8 L e as seguintes dimensões: 1 metro de altura e $100 \mathrm{~mm}$ de diâmetro. A lâmpada emissora de radiação UV foi acoplada na tampa do reator, dentro de um tubo de quartzo e ficou verticalmente submersa no efluente amostrado, possibilitando a entrada do fluxo por batelada e facilitando a conexão elétrica da lâmpada. Apesar de no reator da ETE/UFLA as lâmpadas estarem em posição horizontal, a lâmpada utilizada no reator de bancada era do mesmo comprimento que lâmina d'água, de forma que a radiação ultravioleta atingiu todo o efluente amostrado. Na parte externa do reator foi acoplada uma mangueira de nível e três torneiras de saída, sendo a primeira posicionada a $10 \mathrm{~cm}$ do fundo e as demais $30 \mathrm{~cm}$ umas das outras. Internamente, o reator foi completamente revestido de papel alumínio, com o intuito de simular as condições de reflexão presentes do reator da Estação de Tratamento de Efluentes da UFLA que é de aço inox. A lâmpada do reator de bancada foi idêntica à utilizada pela estação, da marca PHILIPS, modelo TUV36T5 HO 4P SE e potência de 75 W e comprimento de onda de $254 \mathrm{~nm}$. 
O experimento foi conduzido em três eventos, de forma que foram avaliados seis pontos, sendo eles: antes da passagem do efluente pela radiação UV e após o contato com lâmpada UV por 10 (tempo de projeto da ETE), 20, 30, 40 e 50 segundos. As amostras foram obtidas pela retirada do efluente da torneira em posição intermediária.

Figura 2 - Lâmpada Philips 75 W utilizada no experimento, acoplada ao reator de PVC, revestido internamente por papel alumínio

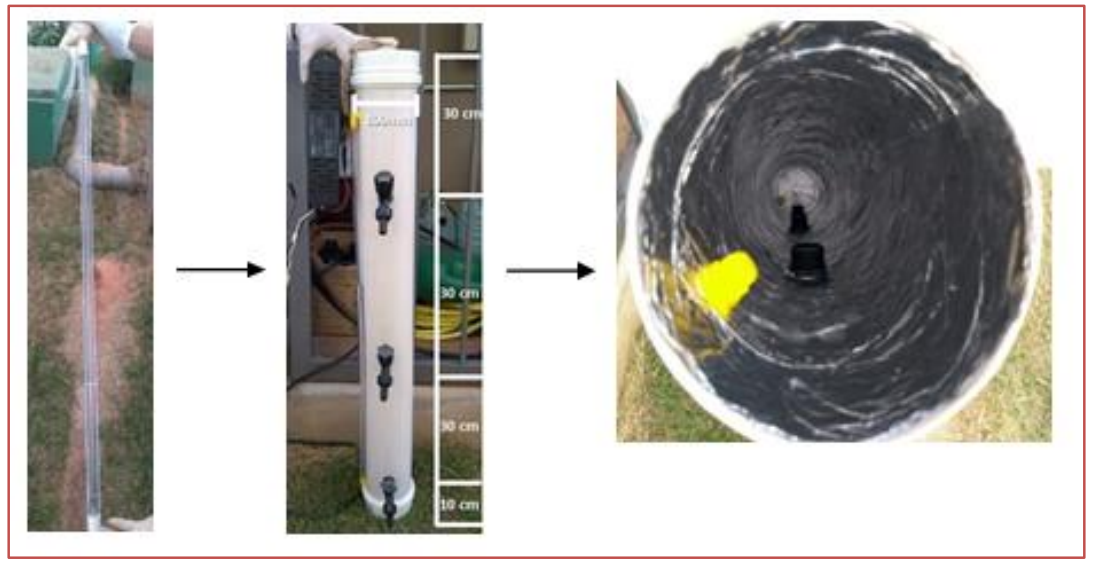

Fonte: Do autor.

\subsection{FILTRO DE AREIA}

Após esses primeiros ensaios, foram realizados outros dois ensaios nos quais o efluente passou previamente pelo filtro de areia. 0 dimensionamento do filtro em escala de bancada foi feito com base nas condições da caixa de filtração da ETE/UFLA, que, como mencionado anteriormente, possui altura de 1,55 $\mathrm{m}$, área superficial de 2,4 $\mathrm{m}^{2}$, com capacidade para TAS de $150 \mathrm{~m} 3 \mathrm{~m}-2 \mathrm{~d}-1$. Assim, para o presente estudo foi considerada uma porosidade de 0,4 (areia fina) e, através da equação 1 , foi possível encontrar o número de volume de poros de 242 .

$$
n V p=\frac{\varrho}{\text { Vporos }}(1)
$$

Encontrado o número de volume de poros, foi possível usá-lo para o dimensionamento do filtro em escala de bancada, por meio das equações 2 e 3, através das quais foram obtidos o volume útil de passagem do efluente e, em seguida, o volume total do reator de bancada.

$$
\begin{gathered}
n V p=\frac{Q}{V u ́ t i l}(2) \\
\text { Vtotal }=\frac{\text { Vútil }}{\text { porosidade }}(3)
\end{gathered}
$$

Realizados os cálculos, foi possível construir o filtro de areia em escala de bancada, em PVC, com as seguintes dimensões: $50 \mathrm{~cm}$ de altura e $100 \mathrm{~mm}$ de diâmetro.

Em relação ao material suporte e ao meio filtrante, foram adicionadas uma camada de $5 \mathrm{~cm}$ pedra britada de tamanho zero e uma camada de $25 \mathrm{~cm}$ de areia com granulometria fina (diâmetro do grão entre 0,05 e $0,3 \mathrm{~mm}$ ), respectivamente. 
No fundo do tubo de PVC foi adicionado um funil de $5 \mathrm{~cm}$ de altura e $100 \mathrm{~mm}$ de diâmetro para facilitar a coleta do afluente. A fim de reter pedregulhos e partículas sólidas brutas, foram inseridos dois ralos de cozinha, um ao final do filtro e outro ao final do funil.

O sistema de alimentação do filtro foi composto por uma bombona de 500 litros e por uma torneira que permitia a saída do efluente. Junto à tampa da bombona foi acoplado um tudo de PVC, caracterizando um Sistema de Mariotti, o que possibilitou manter constante a vazão do efluente pela torneira. Vale destacar que antes de se fazerem as coletas, o sistema de alimentação ficou ligado por uma semana para promover o desenvolvimento de atividade biológica no leito filtrante.

Dessa forma, foram realizados dois ensaios no filtro de bancada, a duas taxas de aplicação superficiais diferentes. No primeiro ensaio foi adotada uma TAS de $150 \mathrm{~m} 3 \mathrm{~m}-2 \mathrm{~d}-1$, tal qual o que determina o projeto da ETE/UFLA. Para o segundo ensaio, foi atribuída uma TAS de 7,2 m3m- 2d-1, de acordo com o recomendado em literatura para desinfecção de água bruta (MURTHA; HELLER, 2003).

Figura 3 - Bombona de alimentação do filtro (A),filtro em escala de bancada com as respectivas dimensões (B), internamente preenchido por uma camada de $5 \mathrm{~cm}$ de brita zero (C) e por uma camada de $25 \mathrm{~cm}$ de areia fina (D).

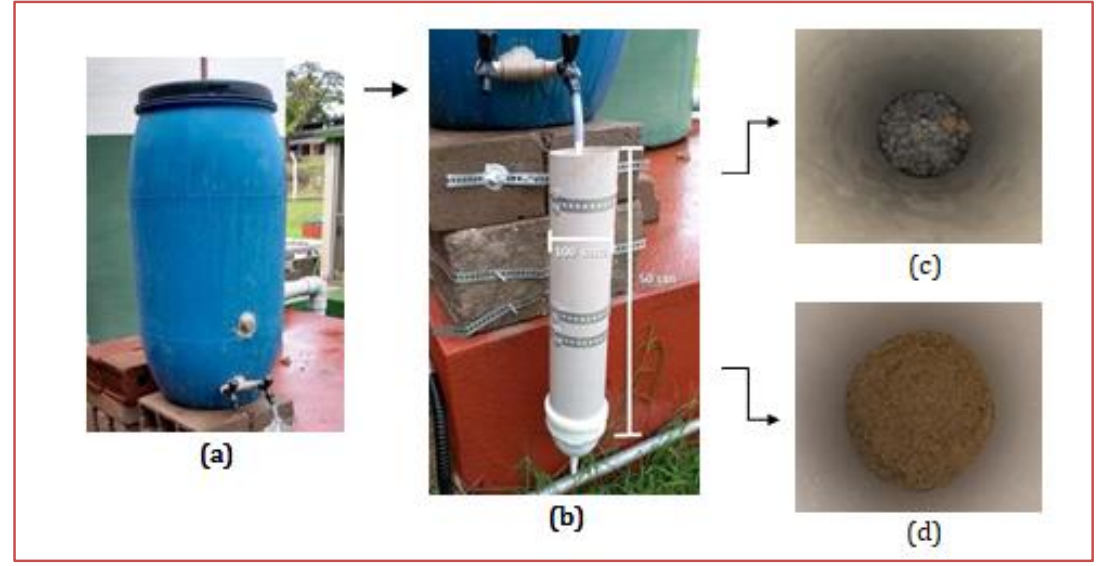

Fonte: Do autor

\subsection{ANÁLISE TÉRMICA}

A fim de verificar a influência da temperatura na inativação de coliformes, foi realizada uma análise térmica do reator ultravioleta com o auxílio de uma câmera termográfica da marca FLIR modelo E50. 0 estudo térmico foi realizado antes de o reator ser ligado, e ligado após 10, 20, 30, 40 e 50 segundos.

Figura 4 - Câmera termográfica FLIR modelo E50.

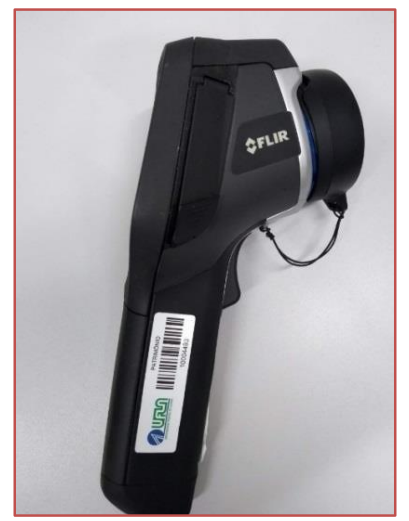

Fonte: Do autor. 


\subsection{ANÁLISES LABORATORIAIS}

Coletadas as amostras, foram feitas as análises de coliformes totais e termotolerantes, cor, turbidez e $\mathrm{pH}$, em laboratório. As análises e a quantificação de coliformes foram feitas de acordo com a metodologia descrita pelo "Standard Methods For The Examination of Water and Wastewater" (APHA,2005).

\subsection{ANÁLISES NO R}

Também foram realizadas análises de correlação entre as variáveis estudadas. Os dados foram tratados através de um ambiente de software livre para computação estatística e gráficos, o RStudio. A versão do R utilizada foi a 3.5.1, enquanto a do RStudio foi 1.1.456. As principais funções utilizadas foram "cor 0 ", “cor.test (0" e a "corrplot (0".

\section{RESULTADOS E DISCUSSÃO}

\subsection{ENSAIOS SEM O FILTRO DE AREIA}

Primeiramente, foram realizados três ensaios sem o filtro de areia antecedendo o reator ultravioleta. A redução logarítmica de coliformes foi estimada de acordo com o Modelo Chick Watson (NGUYEN et al., 2019), evidenciado pela equação 4:

$$
\text { Redução Logarítmica }=\log \left(\frac{C o}{C}\right)(4)
$$

Observando a Equação 4, C0 indica a concentração inicial de coliformes (após a passagem pelo FBAS e antes da passagem pelo reator ) e C a concentração final (após o tempo de contato de 10, 20, 30, 40 e 50 segundos). Realizadas as análises, obtiveram-se os seguintes resultados para coliformes totais e coliformes termotolerantes:

Tabela 1- Contagem de colifomes totais e termotolerantes (repetições 1, 2 e 3, e média geométrica \pm desvio padrão) remanescentes em NMP/100 mL e redução logarítmica (Log C0/C), com tempo de contato de $0,10,20,30,40$ e 50 segundos.

\begin{tabular}{|c|c|c|c|c|c|c|}
\hline \multicolumn{4}{|c|}{ CT (NMP/100 mL) } & \multicolumn{3}{|c|}{ CTerm (NMP/100 mL) } \\
\hline Tempo de contato & Repetições & Média \pm DP & $\log (\mathrm{C} 0 / \mathrm{C})$ & Repetições & Média \pm DP & $\log (\mathrm{C} 0 / \mathrm{C})$ \\
\hline \multirow[t]{3}{*}{ 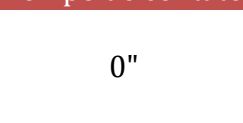 } & $17 \times 105$ & \multirow{3}{*}{$(11,6 \pm 6,1) \times 105$} & \multirow[t]{3}{*}{$\begin{array}{lll}0 & 0\end{array}$} & $2,2 \times 104$ & \multirow{3}{*}{$(2,93 \pm 0,64) \times 104$} & \\
\hline & $4,9 \times 105$ & & & $3,3 \times 104$ & & \\
\hline & $13 \times 105$ & & & $3,3 \times 104$ & & \\
\hline \multirow{3}{*}{$10 "$} & $4,6 \times 105$ & \multirow{3}{*}{$(2,4 \pm 1,9) \times 105$} & \multirow{3}{*}{0,7} & $1,7 \times 104$ & \multirow{3}{*}{$(0,81 \pm 0,84) \times 104$} & \multirow[t]{3}{*}{0,6} \\
\hline & $1,3 \times 105$ & & & $0,023 \times 104$ & & \\
\hline & $1,3 \times 105$ & & & $0,7 \times 104$ & & \\
\hline \multirow{3}{*}{$20 "$} & $0,46 \times 105$ & \multirow{3}{*}{$(0,4 \pm 0,075) \times 105$} & \multirow{3}{*}{1,5} & $0,094 \times 104$ & \multirow{3}{*}{$(0,30 \pm 0,42) \times 104$} & \multirow[t]{3}{*}{1,0} \\
\hline & $0,33 \times 105$ & & & $0,023 \times 104$ & & \\
\hline & $0,33 \times 105$ & & & $0,79 \times 104$ & & \\
\hline \multirow{3}{*}{$30 "$} & $1,3 \times 105$ & \multirow{3}{*}{$(0,7 \pm 0,52) \times 105$} & \multirow{3}{*}{1,2} & $1,1 \times 104$ & \multirow{3}{*}{$(0,53 \pm 0,56) \times 104$} & \multirow[t]{3}{*}{0,7} \\
\hline & $0,33 \times 105$ & & & $0,0045 \times 104$ & & \\
\hline & $0,49 \times 105$ & & & $0,49 \times 104$ & & \\
\hline \multirow{3}{*}{$40 "$} & $0,23 \times 105$ & \multirow{3}{*}{$(0,2 \pm 0,12) \times 105$} & \multirow{3}{*}{1,8} & $2,3 \times 104$ & \multirow{3}{*}{$(0,82 \pm 1,28) \times 104$} & \multirow[t]{3}{*}{0,6} \\
\hline & $0,079 \times 105$ & & & $0,002 \times 104$ & & \\
\hline & $0,33 \times 105$ & & & $0,17 \times 104$ & & \\
\hline \multirow{3}{*}{$50 "$} & $0,79 \times 105$ & \multirow{3}{*}{$(0,6 \pm 0,17) \times 105$} & \multirow{3}{*}{1,3} & $0,22 \times 104$ & \multirow{3}{*}{$(0,13 \pm 0,11) \times 104$} & \multirow[t]{3}{*}{1,4} \\
\hline & $0,49 \times 105$ & & & $0,0018 \times 104$ & & \\
\hline & $0,49 \times 105$ & & & $0,17 \times 104$ & & \\
\hline
\end{tabular}


Para os valores obtidos, observa-se que para coliformes totais, a remoção foi de 79,3\%, 96,6\%, 94,0\%, 98,3\% e 94,8\% para os tempos de 10, 20, 30, 40 e 50 segundos, respectivamente, com redução de 0,7; 1,5; 1,2; 1,8 e 1,3 log para os mesmos tempos. Já para coliformes termotolerantes, a remoção foi equivalente $72,4 \%, 89,8 \%, 81,9 \%, 72 \%$ e $95,6 \%$ para os tempos de 10, 20, 30, 40 e 50 segundos, com redução de 0,6; 1,$0 ; 0,7 ; 0,6$ e $1,2 \log$.

Bilotta e Daniel (2012) realizaram estudos nos quais encontraram reduções de 1,12 log e 1,30 log de Escherichia Coli e coligafos para tempos de contato de 60 e 120 segundos, em um arranjo de 6 lâmpadas de $15 \mathrm{~W}$ cada. Comparando os resultados, evidencia-se que o aumento do tempo de contato não corresponde necessariamente ao aumento da redução de coliformes na mesma proporção, visto que, nesse trabalho, para coliformes totais, a partir de 50 segundos a redução foi menor que para 40 segundos e algo semelhante foi observado por Bilotta e Daniel (2012), cuja diferença de 1 minuto de exposição resultou em uma redução de apenas 0,18 log da população de bactérias. Wen et al. (2019), também verificaram que, para Escherichia Coli, nos tempos de contato de 20, 40, 60, 80, 110, 140 e 180 segundos a remoção foi de $2,1,3,1,4,2$,

4,5, 6, 6, e $6 \mathrm{log}$, respectivamente, com destaque para os tempos de 110, 140 e 180 segundos, nos quais o aumento da dose não interferiu da taxa de inativação. 0 fenômeno descrito acima ocorre, provavelmente, devido à capacidade de fotorreativação das bactérias, de forma que a partir de uma determinada dose, a tendência é de constância da inativação por radiação UV, observando-se baixas ou nenhuma variação.

Para o tempo de projeto do reator ultravioleta da ETE que é de 10 segundos, observou- se a menor taxa de remoção de coliformes totais (de 79,3\% em relação ao tempo zero) e termotolerantes (de 72,4\% em relação ao tempo zero), provavelmente devido ao baixo tempo de exposição e, consequentemente, à baixa dose à qual os microrganismos ficam expostos, visto que para uma mesma lâmpada, a dose aumentará proporcionalmente ao aumento do tempo de contato.

A fim de avaliar os dados estatisticamente, com os resultados das populações remanescentes de coliformes totais e termotolerante, foram tiradas as medidas descritivas entre as repetições, sendo elas: mediana (segundo quartil), valor máximo, valor mínimo, primeiro quartil e terceiro quartil. Com tais medidas, foram plotados os seguintes gráficos tipo boxplot:

Figura 5 - Gráfico boxplot para a população remanescente de coliformes totais, nos tempos de 0, 10, 20, 30,40 e 50 segundos.

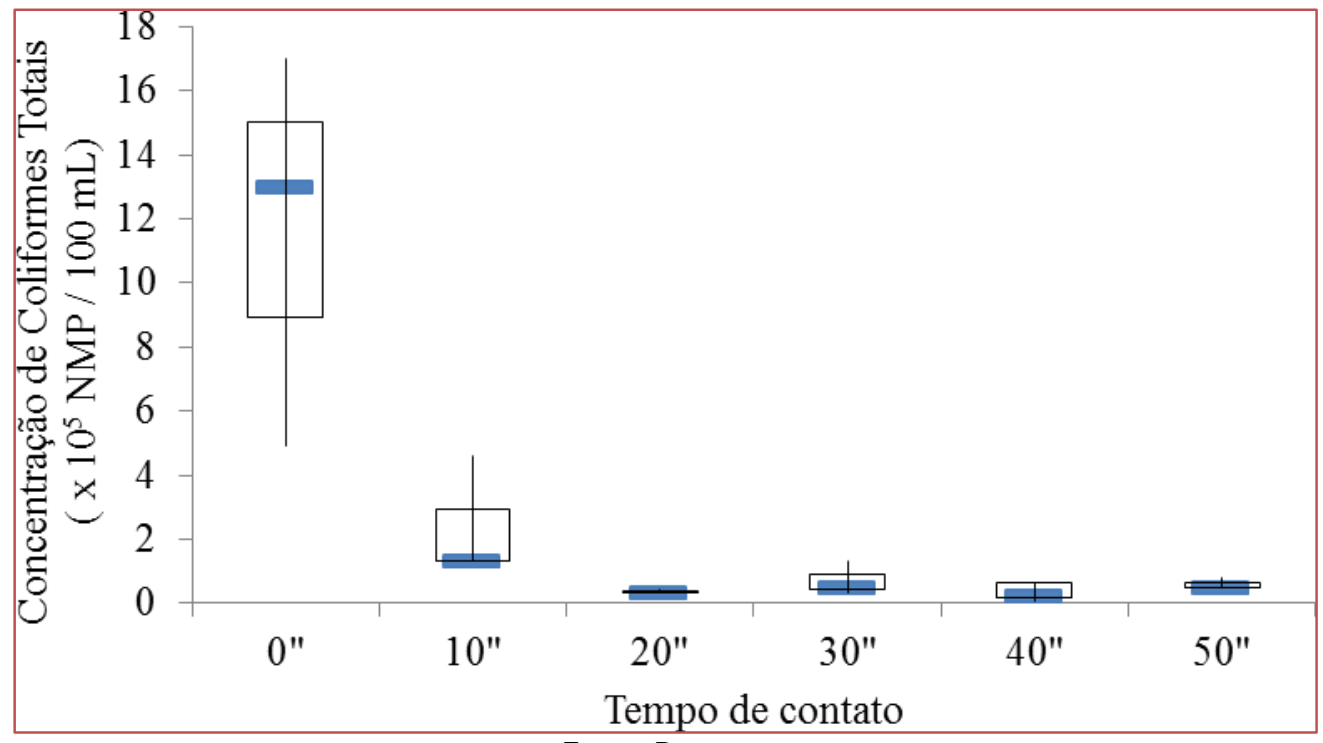

Fonte: Do autor. 
Figura 6 - Gráfico boxplot para a população remanescente de coliformes termotolerantes, nos tempos de $0,10,20,30,40$ e 50 segundos.

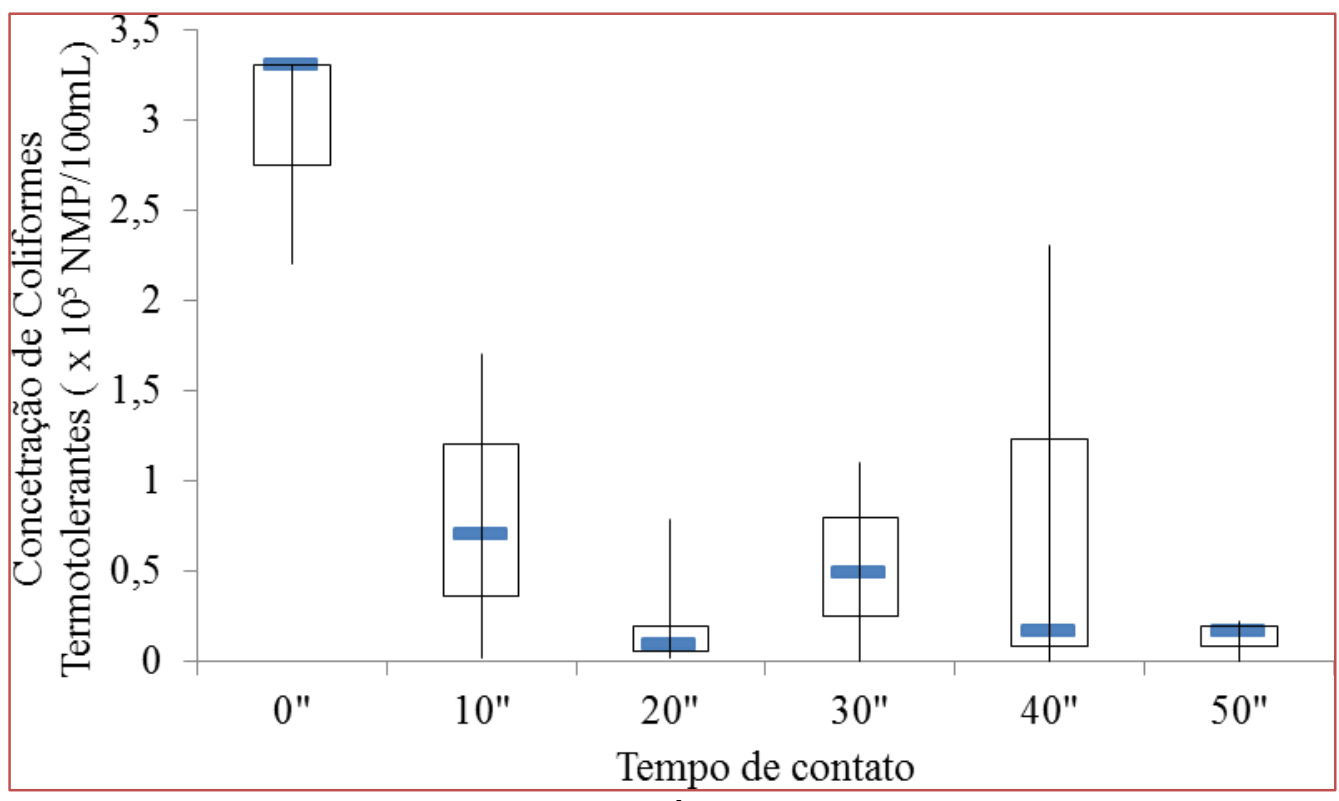

Fonte: do autor

Observando a Figura 5, nota-se que o tempo zero foi o que apresentou maior dispersão entre os valores, ou seja, maior quantidade de valores distantes do valor central (mediana), o que indica elevada variabilidade entre as repetições realizadas para esse tempo. Em relação aos tempos de 10, 20, 30, 40 e 50 segundos, a dispersão entre os valores foi menor, de forma que todos os valores ficaram aglomerados em um pequeno intervalo, indicando que os valores obtidosnas repetições foram próximos entre si, variando de 0 a 4 × $105 \mathrm{NMP} / 100 \mathrm{~mL}$ para 10 segundos e de 0 a 2 x $105 \mathrm{NMP} / 100 \mathrm{~mL}$ para os demais tempos de contato.

Por outro lado, ao analisar a Figura 6, percebe-se que nos tempos zero, 10, 30 e 40 segundos houve elevada dispersão entre os valores, o que permite inferir que as repetições variaram muito entre si. Em contrapartida, para os tempos de 20 e 50 segundos, a dispersão entre os valores foi baixa, que ficaram aglomerados no intervalor de 0 a 1 x 105 NMP/100 mL e de 0 a 0,5 x 105 NMP/100 mL, respectivamente.

Os casos em que se observaram elevadas variações entre as repetições elevado grau de dispersão) ocorreram, possivelmente, por se tratar de um estudo realizado com efluente sanitário e que, portanto, tem suas características alteradas constantemente. Outra possível explicação é atribuída ao fato do estudo ser realizado com bactérias e, logo, organismos vivos, cujo ciclo de vida, apesar de monitorado, não pode ser totalmente controlado.

Além dos gráficos boxplot, foi realizada a análise estatística, pelo teste de Tukey, utilizando três repetições e nível de $5 \%$ de significância $(\alpha)$, cujos resultados podem ser

conferidos na Tabela 2 .

Tabela 2- ANOVA do método de remoção de Coliformes Totais e Termotolerantes.

\begin{tabular}{|c|l|c|c|c|c|c|c|c|}
\hline \multicolumn{2}{|c|}{ Fonte de Variação } & GL & SQ & QM & Fc & Valor-P & CV (\%) & Média Geral \\
\hline \multirow{3}{*}{ CT } & Tratamentos & 6 & $3,12 \times 1012$ & $5,2 \times 1011$ & 8,039 & 0,0016 & 95,94 & 265272,22 \\
\cline { 2 - 10 } & Resíduos & 11 & $7,12 \times 1011$ & $6,47 \times 1010$ & & & & \\
\hline \multirow{2}{*}{ CTerm } & Total & 17 & $3,83 \times 1012$ & & & & & \\
\hline & Tratamentos & 6 & $1,72 \times 109$ & $2,8 \times 108$ & 6,351 & 0,0043 & 72,95 & 9215,72 \\
\cline { 2 - 10 } & Resíduos & 11 & $4,9 \times 108$ & $4,5 \times 107$ & & & & \\
\hline
\end{tabular}

Notas: ANOVA: análise de variância; GL: graus de liberdade; SQ: soma dos quadrados; QM: médias dos quadrados; CV: coeficiente de variação. 
De acordo com a Tabela 2, tanto para coliformes totais como para coliformes termotolerantes, $\mathrm{o}$ valor de $\mathrm{p}$ foi menor que o nível de significância adotado $(\mathrm{p}<\alpha)$ indicando que a diferença entre as médias são estatisticamente significativas, de forma que tanto para coliformes totais como para termotolerantes observou-se maior diferenciação no segundo tratamento. Tal pressuposto apenas confirma o que foi discutido nos gráficos boxplot, que os dados estão distribuídos em uma ampla faixa de valores, fato esse devido, provavelmente, por se tratar de um estudo feito com microrganismos vivos presentes em efluente sanitário ou às características físicas e químicas do efluente que permitiram uma abundância de microrganismos.Também foram plotadas as linhas de decaimento da população de coliformes ao longo do tempo. As tendências de redução das populações de coliformes totais e termotolerantes são destacadas nas Figuras 7 e 8:

Figura 7 - Tendência da redução da população de coliformes totais para os tempos de contato de 0, 10, 20, 30,40 e 50 segundos.

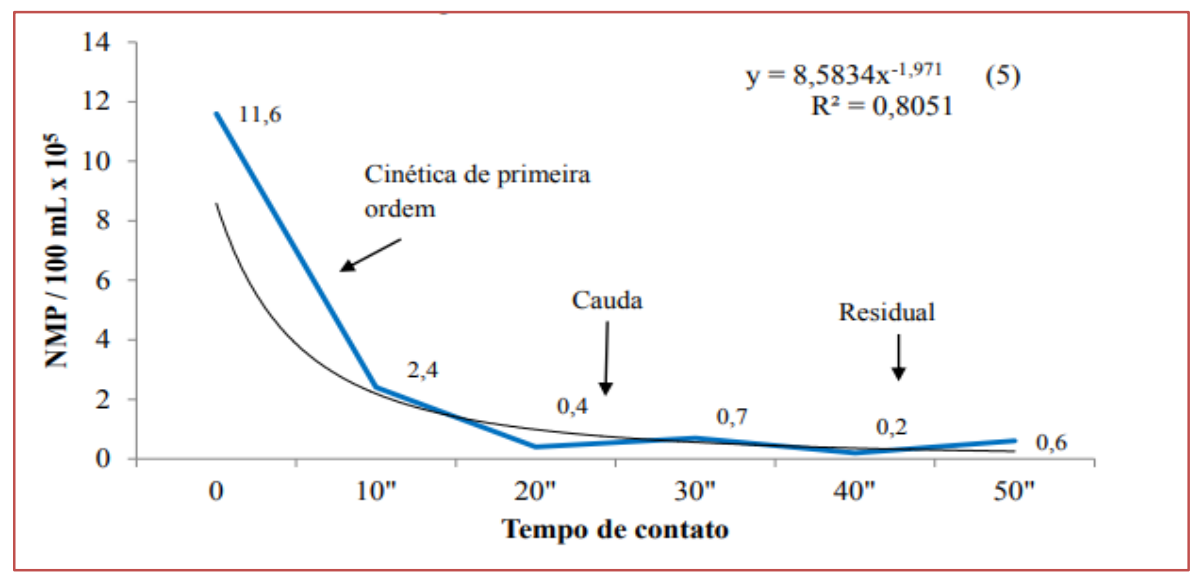

Fonte: Do autor.

Figura 8- Tendência da redução da população de coliformes termotolerantes para os tempos de contato de $0,10,20,30,40$ e 50 segundos.

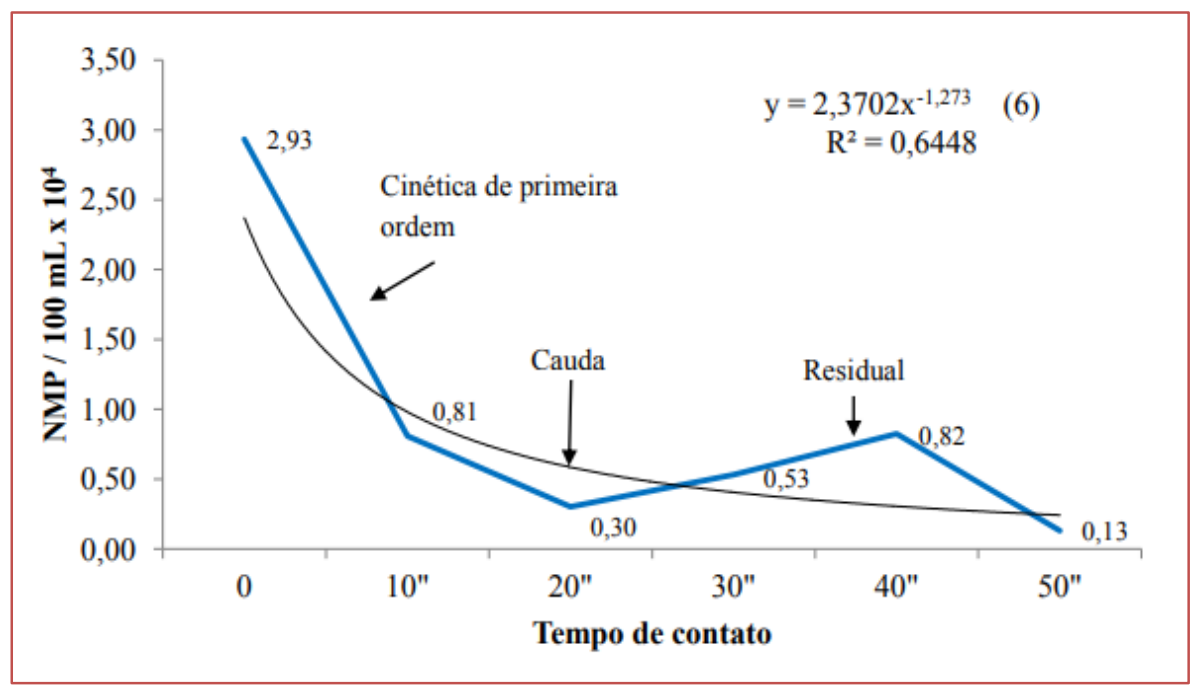

Fonte: Do autor.

Analisando as Figuras 7 e 8, confirma-se a relação direta entre redução da população de bactérias e aumento da taxa de inativação, de forma que, nos ponto em que são observadas as menores populações de coliformes totais e termotolerantes, também são observadas as maiores taxas de inativação desses grupos de microrganismos.

De acordo com o pontuado por Emerick et al. (1999), em doses baixas a inativação de coliformes se dá segundo Cinética de Primeira Ordem. Com o aumento da dose, ocorre um desvio da cinética de primeira 
ordem, na chamada região de Cauda. Elevando ainda mais a dose aplicada, a tendência da população de bactérias é atingir um patamar no qual a dose adicional de UV não interfere mais na inativação, que se mantém constante, essa última fase é denominada Concentração de Bactérias Coliformes Residuais. Assim, foi possível ajustar a equação cinética de primeira ordem (equações 5 e 6) e obter a constante de decaimento (k) para ambos os casos, de forma que, para coliformes totais a constante k assume o valor de 1,962 e, para coliformes termotolerantes, de 1,273. Emerick et al. (1999) também estudaram outros modelos matemáticos que ditam a relação entre coliformes remanescentes, sólidos suspensos, intensidade de UV, tempo de exposição e transmitância, encontrando valores para a constante $\mathrm{k}$ de 1,9, para uma vazão de 1900 m3d-1, e de 2,4 para uma vazão de 4500 m3d-1.

Nessa perspectiva, para o presente estudo, foram identificadas as três regiões mencionadas anteriormente, nas Figuras 7 e 8, de forma que para ambas as comunidades, tanto de coliformes totais quanto para termotolerantes, a Cinética de Primeira Ordem está presente até os primeiros 10 segundos, seguida pela região da Cauda de 10 a 20 segundos e por fim a região de Coliformes Residuais, de 20 a 50 segundos.

Além das análises bacteriológicas, também foram realizadas análises físicas e químicas de temperatura, $\mathrm{pH}$, turbidez e cor, destacadas na tabela abaixo.

Tabela 3- Valores obtidos para Temperatura $\left({ }^{\circ} \mathrm{C}\right), \mathrm{pH}$, Turbidez (UNT) e Cor (mg L-1 Pt/Co) para os tempos de contato de $0,10,20,30,40$, e 50 segundos.

\begin{tabular}{|c|c|c|c|c|}
\hline Tempo de contato $(\mathrm{s})$ & $\mathrm{T}\left({ }^{\circ} \mathrm{C}\right)$ & $\mathrm{pH}$ & Turbidez (UNT) & \multicolumn{2}{c|}{ Cor (mg L-1 Pt/Co) } \\
\hline $0 "$ & $23,4 \pm 3,19$ & $7,0 \pm 0,30$ & $4,4 \pm 1,22$ & $120,6 \pm 37,85$ \\
\hline $10 "$ & $23,8 \pm 3,35$ & $7,1 \pm 0,21$ & $4,3 \pm 0,83$ & $113,2 \pm 39,05$ \\
\hline $20 "$ & $24,1 \pm 3,35$ & $7,0 \pm 0,15$ & $4,6 \pm 1,89$ & $11,9 \pm 42,14$ \\
\hline $30 "$ & $24,4 \pm 4,00$ & $7,3 \pm 0,25$ & $4,5 \pm 1,34$ & $108,5 \pm 37,49$ \\
\hline $40 "$ & $24,7 \pm 3,70$ & $7,1 \pm 0,12$ & $4,4 \pm 1,47$ & $108,2 \pm 45,43$ \\
\hline $50 "$ & $24,8 \pm 3,81$ & $7,1 \pm 0,10$ & $4,5 \pm 1,12$ & $112,4 \pm 38,51$ \\
\hline
\end{tabular}

Fonte: Do autor.

Para as variáveis de Temperatura, $\mathrm{pH}$ e Turbidez, foi observada baixa variabilidade em relação aos tempos de contato. Assim, a Temperatura variou de $23,4 \stackrel{\circ}{\circ} \mathrm{C}$ (tempo zero) até $24,8 \stackrel{\circ}{\circ} \mathrm{C}$ (50 segundos), possibilitando inferir que, mesmo com a emissão de calor pela lâmpada ultravioleta, o tempo de exposição não foi suficiente para que ela esquentasse a água de maneira significativa, com diferença de apenas $1,4^{\circ} \mathrm{O} C$ entre os tempos de contato de zero e 50 segundos. Para o pH, a variação foi ainda menor, sendo a variação máxima equivalente a 0,3 unidades, indicando que durante a exposição do efluente à radiação UV não ocorreram processos que possibilitaram a alteração do pH. Já a cor, relacionada à presença de sólidos dissolvidos, foi o parâmetro que apresentou maior variabilidade, sendo observados valores na faixa de 108,2 até 120,6 mg L-1 de Pt/Co.

Outras variáveis importantes a serem destacadas são a turbidez e a concentração de sólidos suspensos, já que tais variáveis interferem diretamente na eficiência da desinfecção ultravioleta. Quanto à Turbidez, a literatura indica que valores até 5,0 UNT não reduzem a eficiência da inativação de patógenos por radiação UV (OLIVER;COSGROVE,1975), assim, para o presente estudo, cujos dados variaram de 4,3 a 4,6, a turbidez não representou um obstáculo à desinfecção. Como já esperado, a variabilidade foi baixa, pois não foi realizado nenhum tratamento físico que visasse à remoção de turbidez do efluente utilizado e, além disso, após os tratamentos anteriores, espera-se que o efluente já esteja com baixa turbidez. Em relação à concentração de sólidos suspensos, estudos realizados por Bilotta e Daniel (2012) indicam que concentrações de sólidos suspensos acima de $100 \mathrm{mg} \mathrm{L}-1$ tendem a causar efeitos adversos no tratamento ultravioleta, já a NBR 12.209/2011 (ABNT, 2011) recomenda que para que o tratamento UV seja eficaz, a concentração de sólidos suspensos deve ser menor que $40 \mathrm{mg}$ L-1. Segundo Fialho (2019), para o efluente final da UFLA, com o qual foi realizado o teste de desinfecção UV, a concentração de sólidos suspensos foi de 20,0 mg L-1, e, portanto, não representou um obstáculo para o estudo proposto, estando dentro dos padrões recomendados tanto pela literatura quanto pela norma nacional. 


\subsection{ENSAIOS COM O FILTRO DE AREIA}

Em um segundo momento, após a realização dos ensaios apenas com reator UV, foi acoplado, ao sistema, um filtro de areia, pelo qual o efluente passou previamente. Foram utilizadas duas taxas de aplicação superficial: $150 \mathrm{~m} 3 \mathrm{~m}-2 \mathrm{~d}-1$, de acordo com o projeto da ETE/UFLA, e 7,2 m3 m- 2 d-1, de acordo com o encontrado na literatura para desinfecção de água bruta (MURTHA; HELLER, 2003).

TAS $=150 \mathrm{~m}^{3} \mathrm{~m}^{-2} \mathrm{~d}^{-1}$

Para a TAS de $150 \mathrm{~m}^{3} \mathrm{~m}^{-2} \mathrm{~d}^{-1}$, foram obtidos os seguintes resultados:

Tabela 4 - Contagem de colifomes totais e termotolerantes remanescentes em NMP/100 mL, redução logarítmica (Log C0/C), Temperatura $\left({ }^{\circ} \mathrm{C}\right), \mathrm{pH}$, Turbidez (UNT) e Cor (mg L-1 Pt/Co) antes e depois da passagem pelo filtro de areia lento e para os tempos de contato de 10, 20, 30, 40 e 50 segundos e TAS $=150$ $\mathrm{m}^{3} \mathrm{~m}^{-2} \mathrm{~d}^{-1}$

TAS $=150 \mathrm{~m}^{3} \mathrm{~m}^{-2} \mathrm{~d}^{-1}$

\begin{tabular}{|c|c|c|c|c|c|c|c|c|}
\hline \multirow{2}{*}{ Ponto } & \multicolumn{2}{|c|}{ CT(NMP/100mL) } & \multicolumn{2}{|c|}{ CTerm(NMP/100mL) } & \multirow{2}{*}{$\mathrm{T}\left({ }^{\circ} \mathrm{C}\right)$} & \multirow{2}{*}{$\mathrm{pH}$} & \multirow{2}{*}{$\begin{array}{l}\text { Turbidez } \\
\text { (UNT) }\end{array}$} & \multirow{2}{*}{$\begin{array}{c}\text { Cor(mg L-1 } \\
\mathrm{Pt} / \mathrm{Co} \text { ) }\end{array}$} \\
\hline & $\mathrm{NMP} / 100 \mathrm{~mL}$ & $\log (\mathrm{CO} / \mathrm{C})$ & $\mathrm{NMP} / 100 \mathrm{~mL}$ & $\log (\mathrm{CO} / \mathrm{C})$ & & & & \\
\hline Antes do filtro & $33 \times 105$ & - & $13 \times 104$ & - & 24,5 & 6,9 & 6,44 & 163,8 \\
\hline $0 "$ & $9,4 \times 105$ & - & $4,9 \times 104$ & - & 24,2 & 6,9 & 4,95 & 140,5 \\
\hline $10 "$ & $3,5 \times 105$ & 0,42 & $4,9 \times 104$ & 0 & 24,2 & 6,9 & 4,46 & 141,5 \\
\hline $20 "$ & $2,3 \times 105$ & 0,61 & $4,9 \times 104$ & 0 & 24,5 & 6,9 & 4,58 & 135,5 \\
\hline $30 "$ & $2,3 \times 105$ & 0,61 & $4,9 \times 104$ & 0 & 24,5 & 6,9 & 4,51 & 136,5 \\
\hline $40 "$ & $0,49 \times 105$ & 1,28 & $0,79 \times 104$ & 0,79 & 24,9 & 6,9 & 3,97 & 128,4 \\
\hline $50 "$ & $0,49 \times 105$ & 1,28 & $4,2 \times 104$ & 0,07 & 24,8 & 7,0 & 4,14 & 133,4 \\
\hline
\end{tabular}

Ao analisar a Tabela 4, percebe-se que o filtro de areia proporcionou uma remoção de 71,5\% para a concentração de coliformes totais e de $62,3 \%$ para coliformes termotolerantes em relação ao efluente inicial.

Para coliformes totais, em relação ao tempo de contato zero, a remoção foi de $62,7 \%, 75.5 \%, 75,5 \%, 94,7 \%$ e 94,7\% nos tempos de 10, 20, 30, 40 e 50 segundos, respectivamente. A redução foi de 0,42, 0,61, 0,61, 1,28 e 1,28 log para os mesmos tempos, indicando a tendência da inativação alcançar a constância. Para coliformes termotelarantes, em relação ao tempo de contato zero, não houve decaimento da população até o tempo de 40 segundos, sendo que, a partir desse ponto, a remoção foi de 83,8\% e 14,3\% para os tempos de 40 e 50 segundos, respectivamente. Para os mesmos tempos, as reduções foram equivalentes a 0,79 e 0,07 unidades logarítmicas.

Em relação às demais variáveis, a temperatura e o pH foram os que apresentaram menor variabilidade, sendo observada uma variação de apenas $0,7 \stackrel{\circ}{\circ}$ para Temperatura e de 0,12 unidades para pH. Quanto à turbidez e à cor, a diferença observada foi maior, especialmente nos pontos antes e após a passagem pelo filtro, indicando a retenção de partículas sólidas. Apesar de maiores, as remoções de Turbidez e Cor foram de apenas $23 \%$ e $14,22 \%$, respectivamente, o que pode ser devido à elevada taxa de aplicação superficial utilizada.

Para a TAS de $150 \mathrm{~m} 3 \mathrm{~m}-2$ d-1 foi feita a análise de correlação entre as variáveis propostas, como é evidenciado na Figura 9: 
Figura 9 - Correlação entre as variáveis Coliformes Totais, Coliformes Termotolerantes, Turbidez, Cor, pH e Temperatura, para a TAS=150 m3m-2d-1.

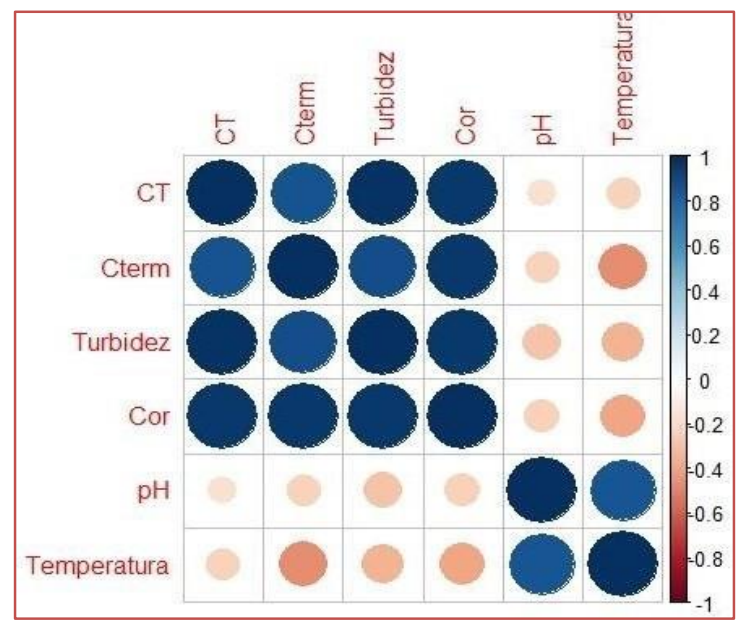

Fonte: Do autor.

De acordo com a Figura 9 é possível notar que há uma elevada correlação positiva entre turbidez e coliformes totais e termotolerantes, ou seja: quanto maior a turbidez, maior será a concentração de bactérias remanescentes, e o mesmo é válido para a correlação contrária: quanto menor a turbidez, menor será a concentração de bactérias remanescentes . Uma vez que a turbidez está diretamente relacionada à presença de sólidos suspensos, fica claro que o controle dessa variável através de processos físicos é fundamental para garantir a aplicabilidade e a eficácia do tratamento ultravioleta. Kumar et al. (2009) também realizaram estudos da correlação entre variáveis físicas, químicas e microbiológicas após tratamento com filtro lento de areia, encontrando uma correlação equivalente a 0.96539 entre turbidez e coliformes totais.

0 mesmo é observado para a cor: quanto menor a cor, menor a concentração de bactérias remanescentes, e vice-versa. Já as variáveis pH e temperatura não apresentaram nenhuma correlação significativa com outras variáveis, indicando que elas não interferem diretamente no tratamento ultravioleta.

TAS $=7,2 \mathrm{~m}^{3} \mathrm{~m}^{-2} \mathrm{~d}^{-1}$

Já para o ensaio com filtro de areia e TAS de $7,2 \mathrm{~m}^{3} \mathrm{~m}^{-2} \mathrm{~d}^{-1}$, os resultados obtidos foram os seguintes:

Tabela 5 - Concentração de Coliformes Totais e Termotolerantes remanescentes em NMP/100 mL, redução logarítmica (Log C0/C), Temperatura $\left({ }^{\circ} \mathrm{C}\right)$, pH, Turbidez (UNT) e Cor (mg L-1 Pt/Co) antes e depois da passagem pelo filtro de areia lento e para os tempos de contato de 10, 20, 30, 40 e 50 segundos e TAS $=7,2 \mathrm{~m} 3 \mathrm{~m}-2 \mathrm{~d}-1$.

TAS $=7,2 \mathrm{~m}^{3} \mathrm{~m}^{-2} \mathrm{~d}^{-1}$

\begin{tabular}{|c|c|c|c|c|c|c|c|c|}
\hline \multirow{2}{*}{ Ponto } & \multicolumn{2}{|c|}{ CT (NMP/100 mL) } & \multicolumn{2}{|c|}{ CTerm (NMP/100 mL) } & \multirow{2}{*}{$\mathrm{T}\left({ }^{\mathrm{o}} \mathrm{C}\right)$} & \multirow{2}{*}{$\mathrm{pH}$} & \multirow{2}{*}{$\begin{array}{l}\text { Turbidez } \\
\text { (UNT) }\end{array}$} & \multirow{2}{*}{$\begin{array}{l}\text { Cor(mg L } \\
-1 \mathrm{Pt} / \mathrm{Co})\end{array}$} \\
\hline & $\mathrm{NMP} / 100 \mathrm{~mL}$ & $\log (\mathrm{CO} / \mathrm{C})$ & $\mathrm{NMP} / 100 \mathrm{~mL}$ & $\log (\mathrm{CO} / \mathrm{C})$ & & & & \\
\hline Antes do filtro & $2,3 \times 105$ & - & $3,5 \times 104$ & - & 24,5 & 6,9 & 1,2 & 83,9 \\
\hline $0 "$ & $2,3 \times 105$ & - & $3,5 \times 104$ & - & 25,4 & 6,9 & 0,7 & 67,7 \\
\hline 10" & $0,49 \times 105$ & 0,67 & 1,4 x 104 & 0,40 & 25,5 & 7,1 & 0,9 & 77,8 \\
\hline $20 "$ & $0,22 \times 105$ & 1,02 & $0,35 \times 104$ & 1,00 & 25,3 & 7,1 & 0,9 & 71,8 \\
\hline $30 "$ & $0,11 \times 105$ & 1,32 & $0,11 \times 104$ & 1,50 & 25,4 & 7,1 & 0,9 & 66,7 \\
\hline $40 "$ & $0,33 \times 105$ & 0,84 & $0,92 \times 104$ & 0,58 & 25,7 & 7,1 & 1,2 & 71,8 \\
\hline $50 "$ & $0,049 \times 105$ & 1,67 & $0,079 \times 104$ & 1,65 & 26,9 & 7,1 & 1,0 & 74,8 \\
\hline
\end{tabular}

Fonte: Do Autor. 
De acordo com a Tabela 5, para a segunda TAS proposta, observa-se que não houve remoção de coliformes totais ou termotolerantes antes e após a passagem do efluente pelo filtro de areia. Tal resultado contraria o encontrado em literatura, pois de acordo com Murtha e Heller (2003), quanto menor a taxa de aplicação maior deveria ser a remoção de coliformes pelo leito filtrante, pois, nesse caso, há um maior tempo de contato entre o efluente e o schmutzdecke. Ellis (1987) também realizou um teste de desinfecção por filtro lento de areia a uma taxa de 7,0 m3m-2 d-1 para efluentes domésticos, e encontrou uma redução de 96\% da população de coliformes após a passagem pelo filtro. Frente a isso, uma possível hipótese para os resultados encontrados seria a não formação de uma camada biológica suficientemente rica acima do leito filtrante, visto que é nessa camada onde ocorre a maior taxa de remoção de coliformes, como aponta Murtha e Heller (2003).

Após a passagem pelo filtro, para coliformes totais, a remoção foi de 78,7\%, 90,43\%, 95,21\%, 85,6\% e $97,8 \%$, correspondente a uma inativação de $0,67,1,02,1,32,0,84$ e 1,67 log para os tempos de 10, 20, 30, 40 e 50 segundos, respectivamente. Para coliformes termotolerantes, a remoção foi de $60 \%$, $90 \%, 96,9 \%, 73,7 \%$ e 97,7\%, com inativação de 0,4,1, 1,5, 0,58 e 1,65 log, para os mesmos tempos.

Para as variáveis temperatura e $\mathrm{pH}$, foram observadas baixas variabilidades para os tempos de contato propostos, com diferenças de apenas $2,4 \stackrel{\circ}{\circ} \mathrm{C}$ e 0,23 unidades, respectivamente. Para turbidez, destacam-se os pontos antes e após a passagem do efluente pelo filtro, em que houve remoção de $40 \%$, o dobro do observado para a TAS de 150 m3 m-2 d-1, o mesmo vale para a cor, que apresentou uma redução de $19 \%$.

Para a TAS de 7,2 m3m-2 d-1 também foi feita a análise de correlação entre as variáveis propostas, de acordo com a figura abaixo:

Figura 10 - Correlação entre as variáveis Coliformes Totais, coliformes Termotolerantes, Turbidez, Cor, pH e Temperatura, para a TAS $=150 \mathrm{~m} 3 \mathrm{~m}-2 \mathrm{~d}-1$.

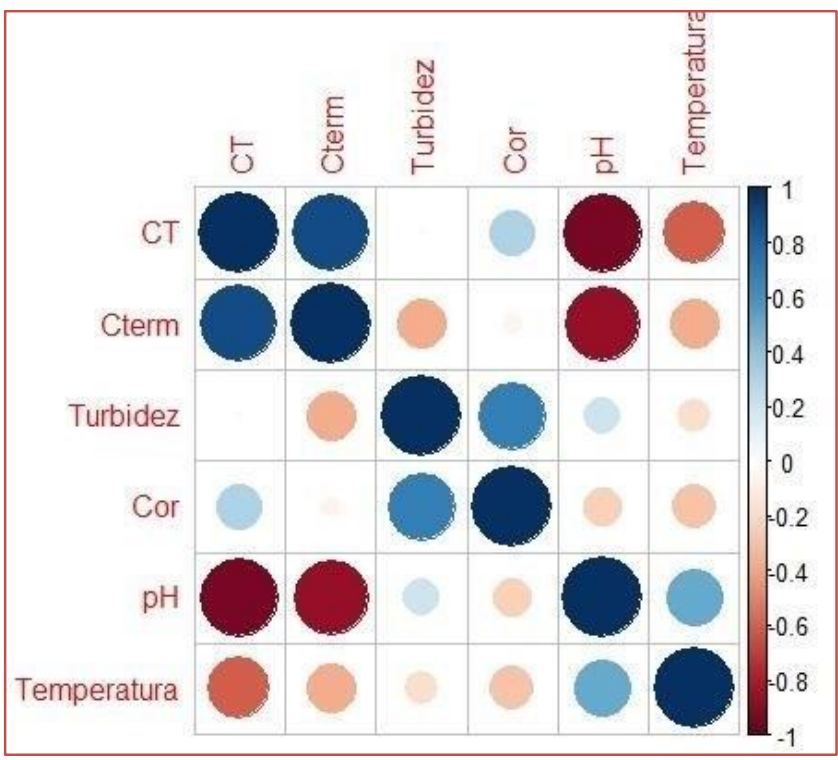

Fonte: Do autor.

Ao contrário do observado anteriormente, para a TAS superficial de 7,2 m3m-2 d-1, não foi observada correlação direta entre as variáveis turbidez, cor, coliformes totais e termotolerantes. Sob outra perspectiva, nesse caso, foi observada uma correlação indireta entre coliformes totais e termotolerantes e $\mathrm{pH}$, de forma que, quanto menor foi o $\mathrm{pH}$, maior foram as concentrações de bactérias remanescentes.

\subsection{ANÁLISES TÉRMICAS}

Com a câmera termográfica, foram obtidas imagens que possibilitaram a análisetérmica do reator ultravioleta. Assim, para a lâmpada desligada e ligada 10, 20, 3040 e 50 segundos, as temperaturas obtidas foram 23,$9 ; 23,1 ; 23,8 ; 24,2 ; 24,0$ e $24,8^{\circ} \mathrm{C}$, respectivamente. 
Figura 11 - Análise térmica do reator ultravioleta, com a lâmpada desligada e ligada 10, 20, 30, 40 e 50 segundos, respectivamente.
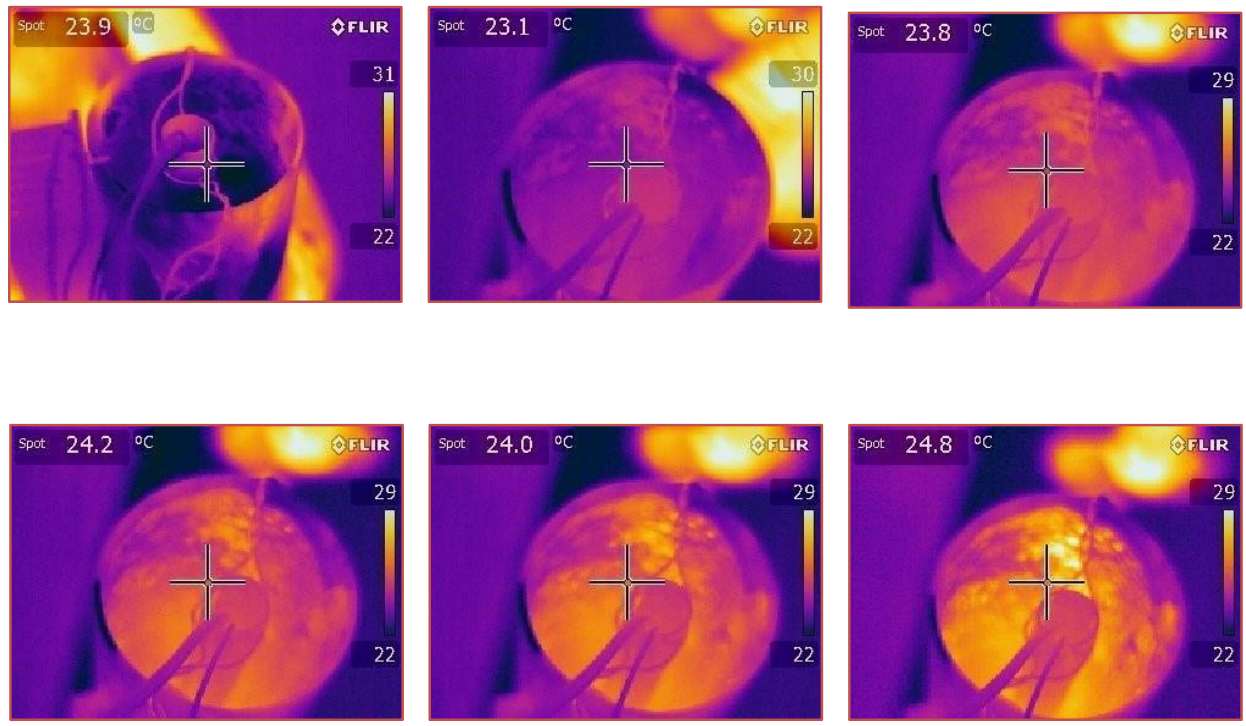

Fonte: Do autor.

Apesar de terem sido observadas mudanças de temperatura, para o tempo proposto, tais mudanças não foram significativas, de forma que não foi observada correlação direta entre o aumento da temperatura e a remoção da população de coliformes. Assim, apesar da lâmpada ultravioleta emitir calor, os tempos de contato estudados não foram suficientes para que o efluente esquentasse a temperaturas que provocassem a inativação de coliformes, visto que uma possível redução na concentração seria observada apenas a partir de $44,5^{\circ} \mathrm{C}$, o que provocaria a supressão de coliformes que não se enquadram no grupo de t ermotolerantes.

\section{CONCLUSÕES}

Através dos testes de inativação com reator ultravioleta, foi possível concluir que, para os tempos de contato propostos, o que apresentou maior remoção da população de coliformes totais foi o de 40 segundos, enquanto que, para coliformes termotolerantes, esse tempo sobe para 50 segundos. Mesmo com 50 segundos de contato, foi produzido um efluente que não pode ser classificado como classe 2 , inviabilizando seu lançamento em cursos d'água pertencentes a essa classe.

O tempo de 10 segundos, projetado para a ETE/UFLA, não mostrou reduções significativas das populações de coliformes t otais ou t ermotolerantes. Entretanto, apenas com o reator de bancada não é possível prever com segurança a eficiência da Estação da UFLA para a inativação de coliformes, visto que, para essa estação, a configuração projetada é de 20 lâmpadas e não foi realizado um estudo aprofundado sobre a relação entre inativação de bactérias e dose de radiação aplicada.

Acoplando-se o filtro de areia no sistema, a melhor combinação encontrada foi para taxa de aplicação superficial de 7,2 m3m-2 d-1 e o tempo de contato de 50 segundos, sendo que, nessas condições, foi produzido um efluente que não interfere na qualidade de corpos hídricos de classe 2. Tal resultado permite concluir a importância de se acoplar um tratamento físico previamente ao tratamento por radiação UV, visando à remoção de sólidos suspensos remanescentes e de turbidez, variáveis estas que afetam diretamente na eficiência do tratamento. 


\section{REFERÊNCIAS}

[1] AFSHARNIA, M. et al. Disinfection of dairy wastewater effluent through solar photocatalysis processes. Water Science and Engineering, v. 11, n. 3, p. 214-219, 2018.

[2] AMERICAN PUBLIC HEALTH ASSOCIATION. Standard Methods for the Examination of Water and Wastewater. 20th, Washington: APHA, 1998.

[3] ARASHIRO, L. T. et al. The effect of primary treatment of wastewater in high rate algal pond systems: Biomass and bioenergy recovery. Bioresource technology, v. 280, p. 27-36, 2019.

[4] ASSOCIAÇÃO BRASILEIRA DE NORMAS TÉCNICAS. NBR 13969/97: Tanques sépticos - Unidades de tratamento complementar e disposição final dos efluentes líquidos - Projeto, construção e operação: Rio de Janeiro, p. 60, 1997.

[5] ASSOCIAÇÃO BRASILEIRA DE NORMAS TÉCNICAS. NBR 12209/11: Elaboração deprojetos hidráulicosanitários de estações de tratamento de esgotos sanitários: Rio de Janeiro, p. 53, 2011.

[6] BILOTTA, P.; DANIEL, L. A. Utilização de Lâmpadas germicidas na desinfecção de esgoto sanitário. Revista Ambiente e Agua - An Interdisciplinary Journal of Applied Science , v. 7, n. 1, 2012.

[7] BRASIL. Lei № 8.080, de 19 de setembro de 1990, Art. 3o.Disponível em:<http://www.planalto.gov.br/ccivil_03/leis/l8080.htm>. Acesso em: 10 jun. 2019.

[8] BRASIL. Ministério das Cidades. Organização Pan-Americana da Saúde. Política e plano municipal de saneamento ambiental: experiências e recomendações. Programa de Modernização do Setor de Saneamento. Organização Panamericana da Saúde - Ministério das Cidades. Brasília, 2005.

[9] CAIRNCROSS, S. The public health benefits of urban sanitation in low and middle income countries. Utilities Policy, v. 51, p. 82-88, 2018.

[10] CAMPOS, J. R. et al. Tratamento de esgostos sanitários por processo anaeróbio e disposiçao controlada no solo. In: Tratamento de esgostos sanitários por processo anaeróbio e disposiçao controlada no solo. ABES, 1999.

[11] CARRÉ, E. et al. Impact of suspended particles on UV disinfection of activated-sludge effluent with the aim of reclamation. Journal of water process engineering, v. 22, p. 87-93, 2018.

[12] CARUSO, B. A. et al. SSM - Population Health The association between women's sanitation experiences and mental health: A cross-sectional study in Rural, Odisha India. SSM - Population Health, v. 5, p. 257-266, 2018.

[13] BRASIL, Resolução CONAMA n³57, de 17 de março de 2005. Classificação de águas, doces, salobras e salinas do Território Nacional. no. 053, p.58-63, 2005.

[14] CORCORAN, E., et al. Sick water? The central role of wastewater management in sustainable development - A rapid response assess ment. UNEP (United Nations Environment Programme), Nairobi, Kenia, 2010.

[15] DATASUS. Paraná: Saneamento traz saúde, produtividade e renda. Publicado em: 25 abr. 2014. Disponível em: <http://datasus.saude.gov.br/nucleos-regionais/parana/noticias- parana/438- parana-saneamento-traz-saudeprodutividade-e-renda>. Acesso em: 10 jun. 2019.

[16] DEILAMI, K. et al. Application of landscape epidemiology to assess potential public health risk due to poor sanitation. Journal of environmental management, v. 192, p. 124-133, 2017.

[17] DE MENDONÇA, M. J. C.; DA MOTTA, R. S. Saúde e Saneamento no Brasil. Instituto de Pesquisa Econômica Aplicada, 2005.

[18] DIMAPILIS, E. A. S. et al. Zinc oxide nanoparticles for water disinfection. Sustainable Environment Research, v. 28, n. 2, p. 47-56, mar. 2018.

[19] ELLIS, K. V. Slow sand filtration as a technique for the tertiary treatment of municipal sewages. Wate $r$ Research, v. 21, n. 4, p. 403-410, 1987.

[20] EMERICK, R. W. et al. Factors influencing ultraviolet disinfection performance part II: association of coliform bacteria with wastewater particles. Water environment research, v. 71, n. 6, p. 1178-1187, 1999.

[21] FIALHO, D. E. S. Emprego de tratamentos terciários para desinfecção de efluente sanitário: inativação de coliformes por UV e cloração e verificação de formação de trihalometanos. UFLA, 2019.

[22] FLORES, F. et al. O desenvolvimento do saneamento básico no Brasil e as consequências para a saúde pública. Revista Brasileira de Meio Ambiente, v. 251, p. 241-251, 2018.

[23] FRANCISCO, J. P. et al. Evaluation of the effect of the seed extract of Moringa oleifera Lam over the efficiency of organic filters in wastewater treatment of dairy cattle breeding. Engenharia Agrícola, v. 34, n. 1, p. 143-152, 2014. 
[24] GUO, M. et al. Comparison of low- and medium-pressure ultraviolet lamps : Photoreactivation of Escherichia coli and total coliforms in secondary effluents of municipal wastewater treatment plants. Wate r Research, v. 43, n. 3, p. 815-821, 2009.

[25] HAIG G. S. J. COLLINS R. L. DAVIES C. C. DOREA C. QUINCE. Biological aspects of slow sand filtration: past, present and future. Water science and technology: Water Supply, v. 11, n. 4, p. 379-503, 2011.

[26] HUISMAN, L.; WOOD, W. E. Slow Sand Filtration. World Health Organization - WHO, Geneva, Switzerland, 1974.

[27] IBRAHIM, M. M.; ASAL, S. Physicochemical and photocatalytic studies of Ln 3+ - ZnO for water disinfection and wastewater treatment applications. Journal of Molecular Structure , v. 1149, p. 404-413, dez. 2017.

[28] KOLOSOV, P.; PEYOT, M.; YARGEAU, V. Novel materials for catalytic ozonation of wastewater for disinfection and removal of micropollutants. Science of the Total Environment, v. 644, p. 1207-1218, 2018.

[29] LANGENBACH, K. et al. Modeling of slow sand filtration for disinfection of secondary clarifier effluent. Wate $r$ Research, v. 44, n. 1, p. 159-166, 2010

[30] LATRACH, L. et al. International Journal of Hygiene and Two-stage vertical fl ow multi-soil- layering ( MSL ) technology for e ffi cient removal of coliforms and human pathogens from domestic wastewater in rural areas under arid climate. International Journal of Hygiene and Environmental Health, v. 221, n. 1, p. 64-80, 2018.

[31] LIBÂNIO, P. A. C.; CHERNICHARO, C. A. L.; NASCIMENTO, N. O. A dimensão da qualidade de água: avaliação da relação entre indicadores sociais, de disponibilidade hídrica, de saneamento e de saúde pública. Engenharia Sanitária e Ambiental, v. 10, n. 3, p. 219- 228, 2005

[32] LONDE, L. DE R.; PATERNIANI, J. E. S. Filtração Lenta para Reutilização de Água em Irrigação. Irriga, v. 8, n. 1, p. 10-20, 2003.

[33] MALIK, O. A. et al. A global indicator of wastewater treatment to inform the Sustainable Development Goals (SDGs). Environmental Science \& Policy, v. 48, p. 172-185, 2015.

[34] MANOLI, K. et al. Detailed modeling and advanced control for chemical disinfection of secondary effluent wastewater by peracetic acid. Water research, v. 153, p. 251-262, 2019.

[35] MARRARA, D. A. F. Filtração lenta em areia, manta não tecida e carvão ativado como pós-tratamento de efluente s domesticos e reuso. 2005. 118p. Dissertação (mestrado) - Universidade Estadual de Campinas, Faculdade de Engenharia Civil, Arquitetura e Urbanismo, Campinas, 2005.

[36] MOTTERAN, F.; PEREIRA, E. L.; CAMPOS, C. M. M. Characterization of an acidification and equalization tank (AET) operating as a primary treatment of swine liquid effluent. Brazilian Archives of Biology and Technology, v. 56, n. 3, p. 485-494, 2013

[37] MURTHA, N. A.; HELLER, L. Avaliação da influência de parâmetros de projeto e das características da água bruta no comportamento de filtros lentos de areia. Engenharia sanitária e ambiental, v. 8, n. 4, p. 257-267, 2003.

[38] NDULINI, S. F.; SITHOLE, G. M.; MTHEMBU, M. S. Investigation of nutrients and faecal coliforms removal in wastewater using a hydroponic system. Physics and Chemistry of the Earth, p. 1, abr., 2018.

[39] NGUYEN, T. M. H. et al. Application of a novel, continuous-feeding ultraviolet light emitting diode (UV-LED) system to disinfect domestic wastewater for discharge or agricultural reuse. Wate r research, v. 153, p. 53-62, 2019.

[40] OLIVER, B. G.; COSGROVE, E. G. The desinfection of sewage treatment plant effluents using ultraviolet light. The Canadian Journal of Chemical Engineering, v. 53, p. 170-174, 1975.

[41] ORGANIZAÇÃO MUNDIAL DA SAÚDE - OMS. Constituição da Organização Mundial da Saúde, OMS/WHO, 1946.

[42] SANZ, E. N. et al. Modelling of reactivation after UV disinfection: effect of UV-C dose on subsequent photoreactivation and dark repair. Water research, v. 41, n. 14, p. 3141-3151, 2007.

[43] UFLA. Plano de desenvolvimento institucional pdi 2016-2020. Ministério Da Educação: Universidade Federal de Lavras, p. 283, 2016.

[44] PEDROSO, C. R.l et al. Inativação de microrganismos indicadores de contaminação fecal por radiação ultravioleta e avaliação dos fenômenos de fotorreativação e recuperação no escuro. Engenharia Sanitária e Ambiental, v. 23, n. 5,2018

[45] SALMERÓN, I. et al. Optimization of electrocatalytic H2O2 production at pilot plant scale for solarassisted water treatment. Applied Catalysis B: Environmental, v. 242, p. 327-336, 2019.

[46] SAKER, J. P. P. Saneamento básico e desenvolvimento. 2007. p. 145. Dissertação de mestrado em Direito Político e Econômico - Universidade Presbiteriana Mackenzie, São Paulo, 2007. 
[47] SISTEMA NACIONAL DE SANEAMENTO. Certificação e Manual de Melhores Práticas da Gestão da Informação sobre Saneamento. Disponível em: <http://www.snis.gov.br>. Acesso em: 10 jun. 2019.

[48] SOARES, S. R. A.; BERNARDES, R. S.; NETTO, O. M. C. Relações entre saneamento, saúde pública e meio ambiente: elementos para formulação de um modelo de planejamento em saneamento. Caderno de Saúde Pública, Rio de Janeiro, v. 18, n. 6, p. 1713-1724, 2002.

[49] OLIVEIRA, F. F.; SCHNEIDER, R. P. Slow sand filtration for biofouling reduction in seawater desalination by reverse osmosis. Water research, v. 155, p. 474-486, 2019.

[50] OMAR, K. B.; BARNARD, T. G. The occurrence of pathogenic Escherichia coli in South African wastewater treatment plants as detected by multiplex PCR. Water SA, v. 36, n. 2, p. 172-176, 2010.

[51] TRATA BRASIL. Saneamento - Principais estatísticas. Disponível em: < http://www.tratabrasil.org.br/saneamento/principais-estatisticas>. Acesso em: 10 jun. 2019.

[52] UNICEF; WORLD HEALTH ORGANIZATION-WHO. Progress on Sanitation and Drinking Water:. Update and MDG Assessment. WHO Press, 2015.

[53] UNICEF; WORLD HEALTH ORGANIZATION-WHO. Safely managed drinking water - thematic report on drinking water. WHO Press, 2017.

[54] WEN, G. et al. Photoreactivation of fungal spores in water following UV disinfection and their control using UV-based advanced oxidation processes. Water research, v. 148, p. 1-9, 2019.

[55] WORLD HEALTH ORGANIZATION - WHO. Guidelines for Drinking -water Quality. ed. 4, 2011. 


\section{Capítulo 5}

\section{Acompanhamento da aplicação de nitrogênio em cobertura em lavouras de trigo com aeronave remotamente pilotada}

\section{Fábio Leonardo Prante Bolfe}

Edivan Santin

Cristiano Reschke Lajús

Claudia Klein

André Sordi

Alceu Cericato

Resumo: Um dos fatores que possibilita a condição variável dentro da mesma cultura é conhecido como georreferenciamento agrícola para a criação de mapas e, mais recentemente, o uso de aeronave remotamente pilotada para aquisição de imagens com maior qualidade e de forma mais dinâmica e barata, porém, por ser uma tecnologia nova, carece de informações técnico-cientificas regionais. Os usos de aeronaves remotamente pilotadas auxiliam na descoberta de variáveis com o emprego de imagens de forma mais rápida possibilitando assim a identificação de fatores que possam interferir na produção e tomar medidas para corrigi-los. 0 objetivo deste estudo foi monitorar a adubação nitrogenada de cobertura em lavouras de trigo por aeronave remotamente pilotada (RPA). A adubação nitrogenada nas lavouras de trigo foi manejada da seguinte forma: manejo convencional e manejo via RPA. As variáveis respostas analisadas foram rendimento (kg/ha) e análise econômica. A análise de variância revelou efeito significativo do manejo da adubação nitrogenada e não significativo entre as lavouras em relação às variáveis respostas rendimento, receita, despesa e lucro, evidenciando a superioridade do manejo via RPA em relação ao convencional.

Palavras-chave: ecofisiologia vegetal; inovações tecnológicas; manejo da adubação nitrogenada. 


\section{INTRODUÇÃO}

Para Cirani e Moraes (2010) a Agricultura de Precisão (AP) é o gerenciamento da variabilidade da produção e dos fatores nela envolvidos, realizada por meio de tecnologias recentes adaptadas para o sistema agrícola, com o objetivo de possibilitar a otimização do uso de insumos e reduzir o impacto sobre o meio ambiente. Em virtude disto, a agricultura comercial tem sofrido profundas modificações nos últimos anos, desencadeadas principalmente pelo emprego da tecnologia no campo, direcionada à mecanização dos processos, utilização de insumos químicos, sistema de semeadura direta e biotecnologia.

O uso de sensores remotos possui infinidade de aplicações como, por exemplo, identificação de biomassa, índice foliar, doenças, pragas, estresse hídrico, previsão de rendimento, monitoramento das propriedades do solo e mapeamento. Análises químicas nas folhas, controle e gerenciamento de pragas e plantas daninhas, propriedades superficiais do solo, condições biológicas, parâmetros de clorofila, concentração de nitrogênio na folha, cobertura vegetativa, dentre outros fatores também podem ser monitorados (ZHANG e KOVACS, 2012).

O emprego destas técnicas consiste em aplicar quantidades variáveis de nutrientes em lavouras heterogêneas, dependendo das propriedades peculiares de cada parte da lavoura (GÓMEZ-CANDÓN et al., 2014).

Um dos fatores que possibilita essa condição variável dentro de uma mesma cultura é conhecido como georreferenciamento agrícola para a criação de mapas e, mais recentemente, o uso de aeronave remotamente pilotada (RPA) para aquisição de imagens com maior qualidade, mais dinâmica e barata, porém por ser uma tecnologia nova, carece de informações técnico-cientificas regionais.

Para Primicerio (2015) os usos de aeronaves remotamente pilotadas auxiliam na descoberta de variáveis com o emprego de imagens de forma mais rápida, possibilitando assim a identificação de fatores que possam interferir na produção e tomar medidas para corrigi-los.

O presente trabalho tem como objetivo monitorar a adubação nitrogenada de cobertura em lavouras de trigo por aeronave remotamente pilotada. Seu desenvolvimento busca comparar a utilização aeronave remotamente pilotada com o manejo convencional realizado pelos agricultores da região, analisando e apresentando propostas que possam otimizar o uso de nutrientes nas lavouras.

\section{MATERIAL E MÉTODOS}

0 monitoramento foi realizado em duas lavouras de trigo (1 e 2) situadas na região Oeste de Santa Catarina, localizadas na linha Araçá, interior do município de Maravilha/SC, 2017.

Segundo o sistema de classificação de Köppen, o clima é do tipo Cfa (MENDONÇA; DANNI-OLIVEIRA, 2007).

Os principais sistemas meteorológicos responsáveis pelas chuvas no estado são as frentes frias, a convecção tropical, a ZCAS (Zona de Convergência do Atlântico Sul) e a circulação marítima. Nas regiões mais próximas às encostas de montanhas, as precipitações são mais abundantes, pois a elevação do ar úmido e quente favorece a formação de nuvens cumuliformes, resultando no aumento do volume de precipitação local (MONTEIRO, 2001).

As condições meteorológicas (temperatura e precipitação) foram obtidas no INMET (2018) (Figura 1).

O solo é classificado como CAMBISSOLO háplico (EMBRAPA, 2013).

As lavouras de trigo foram conduzidas com manejo localizado (georreferenciamento) e o mapeamento da área foi realizado com auxílio de um RPA JunoTM Series Trimbleß de navegação, com o qual se demarcou os vértices da área, para geração do mapa e da malha de amostragem. Adotou-se uma malha quadrangular totalizando pontos amostrais, de forma a configurar uma melhor distribuição espacial dos pontos na área.

A malha de amostragem utilizada caracterizou um ponto (amostra) por hectare, o qual foi determinado e georreferenciado através do software Farm Work Office ${ }^{\circledR}$.

As imagens foram obtidas no estádio do afilhamento do trigo, através do emprego de um RPA DJIß Phatom 2 vision, através de uma câmera embarcada, seu payload, que não possibilita calibração da entrada de luz, pois possui abertura fixa de focal ratio 2.8G, com distância focal de $5 \mathrm{~mm}$, deste modo, optou-se por capturar imagens em formato de vídeo, com lente $140^{\circ}$ de Field Of View (FOV) (HARRIS, 
2015) e resolução de $1280 \times 720$ pixels, com o sensor CCD de 1/2.3', ou seja, de 6,16mm x 4,62mm, em um vôo a altura aproximada de 2 metros do solo com GSD de 1,92mm.

Figura 1 - Condições meteorológicas ocorridas durante o experimento

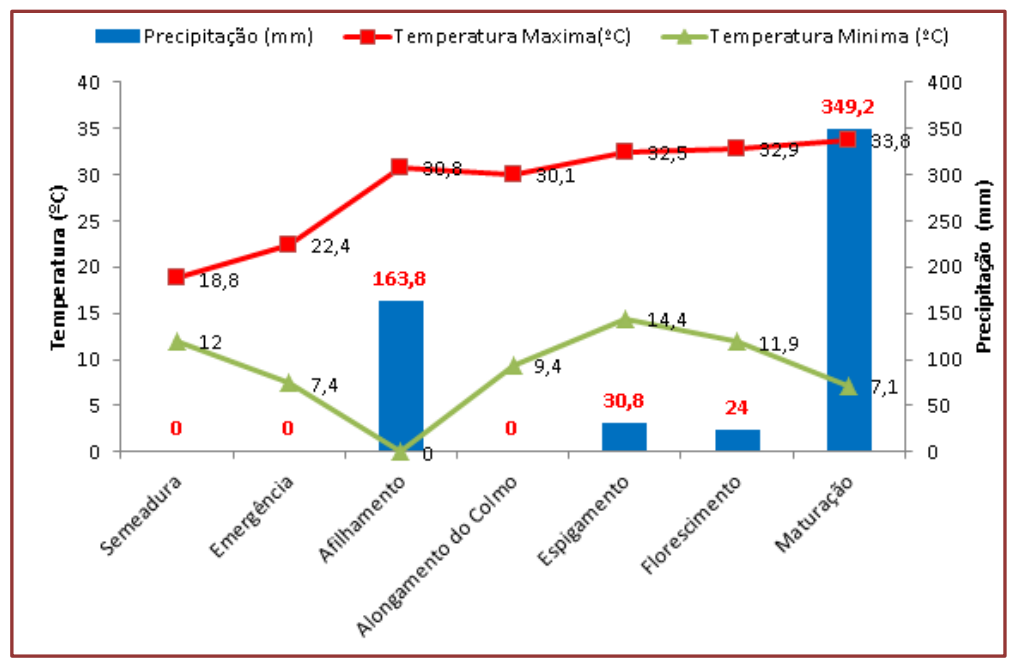

Fonte: elaborado pelos autores.

Na safra 2016, com a pesquisa intitulada "Monitoramento da adubação nitrogenada em cobertura na cultura do trigo de duplo propósito via REMONTELY-PYLOTED AIRCRAFT (RPA) - Edital: no28/UNOESCR/2016, Resolução normativa do CNPq no17/CNPq/2016 e resolução no203/CONSUN/2011", buscou-se a criação do algoritmo de análise computacional, o qual foi validado na safra 2017 nas respectivas lavouras de trigo.

As lavouras de trigo em relação à adubação nitrogenada foram manejadas da seguinte forma: manejo convencional (CQFS-RS/SC, 2016) e manejo via RPA.

No manejo convencional a adubação nitrogenada foi de $15 \mathrm{~kg} /$ hectare na semeadura da cultura, mais aplicação única de $67,5 \mathrm{~kg}$ de nitrogênio no estádio de perfilhamento. Ainda na linha de semeadura foram distribuídos $30 \mathrm{~kg}$ de $\mathrm{P}_{2} \mathrm{O}_{5}$ e $30 \mathrm{~kg}$ de $\mathrm{K}_{2} \mathrm{O}$ por hectare, a formulação $\mathrm{N}, \mathrm{P}, \mathrm{K}$ utilizada em semeadura foi 10:20:20.

A semeadura do cultivar foi realizada no dia 01 de julho de 2017 com um espaçamento entre linhas de $17 \mathrm{~cm}$ e 51 sementes por metro linear, o índice de germinação, e pureza da semente é respectivamente de: $92 \%$ e $98 \%$, totalizando um estande de 270 plantas germinadas por metro quadrado.

Foi realizado o controle de plantas infestantes, moléstias e pragas durante o desenvolvimento da cultura.

A colheita foi feita quando o trigo se encontrava em maturação plena e com umidade de 13\%. Utilizou-se de um quadrado de $25 \mathrm{~cm}$ x $25 \mathrm{~cm}$ totalizando $0,0625 \mathrm{~m}^{2}$ por amostra. Em cada uma das propriedades foram coletadas 10 amostras que posteriormente foram debulhadas manualmente, pesadas em balança analítica na UNOESC, e submetidas a análises de umidade e PH, com os devidos descontos.

No manejo via RPA foi aplicado $15 \mathrm{~kg}$ por hectare de nitrogênio na linha de semeadura, duas aplicações aéreas nos estádios de perfilhamento $(34,5 \mathrm{~kg}$ de $\mathrm{N}$ por hectare) e alongamento de colmo $(5,17 \mathrm{~kg}$ de $\mathrm{N}$ por hectare). Ainda na linha de semeadura foram distribuídos $30 \mathrm{~kg}$ de $\mathrm{P}_{2} \mathrm{O}_{5}$ e $30 \mathrm{~kg}$ de $\mathrm{K}_{2} \mathrm{O}$ por hectare, a formulação N, P, K utilizada em semeadura foi 10:20:20.

A semeadura do cultivar foi realizada no dia 01 de julho de 2017 com um espaçamento entre linhas de $17 \mathrm{~cm}$ e 51 sementes por metro linear, o índice de germinação, e pureza da semente é respectivamente de: $92 \%$ e $98 \%$, totalizando um estande de 270 plantas germinadas por metro quadrado.

Os demais tratos culturais (tratamentos fitossanitários, colheita, análises de PH e umidade) destas lavouras foram os mesmos das lavouras cultivadas em sistema convencional.

As práticas culturais foram realizadas conforme as indicações técnicas da cultura do trigo (EMBRAPA, 2014).

0 cultivar semeada nas lavouras de trigo foi TBIO TORUK ${ }^{\circledR}$. Com caraterísticas interessantes para esta região produtora, com ciclo médio, com estatura das plantas baixas, boa tolerância a moléstias, além disso 
apresenta bom perfilhamento e espigas de trigo uniforme, ainda tendo boa resistência ao acamamento, sua exigência quanto a fertilidade do solo é média/alta (BIOTRIGO, 2014).

As variáveis respostas analisadas foram rendimento ( $\mathrm{kg} / \mathrm{ha}$ ), pelo método proposto pelo MAPA (2009) e análise econômica, utilizando a metodologia de capital ilimitado baseado no preço do kg do fertilizante nitrogenado (ureia) e no preço do kg de grão da cultura do trigo (MATUELLA e SIMIONI, 2015). Os dados coletados foram submetidos a Análise de Variância pelo Teste de $\mathrm{F}$ e as diferenças entre as médias foram comparadas pelo Teste de Tukey $(\mathrm{P} \leq 0,05)$, com auxílio do Software Sisvar 5.0 (FERREIRA, 2010).

\section{RESULTADOS E DISCUSSÃO}

A análise de variância revelou efeito significativo $(P \leq 0,05)$ do manejo da adubação nitrogenada e não significativo para as lavouras em relação à variável resposta rendimento (Tabelas 1 e 2).

Tabela 1 - Rendimento do experimento em relação ao manejo da adubação nitrogenada (Maravilha/SC Safra 2017)

\begin{tabular}{|c|c|}
\hline Manejo da adubação nitrogenada & Rendimento \\
\hline Manejo do produtor & --o---(SC/ha) ------ \\
\hline Manejo via RPA & 48,64 b \\
\hline CV (\%) & 18,04 \\
\hline
\end{tabular}

Médias seguidas de mesma letra não diferem entre si pelo teste de Tukey $(\mathrm{P} \leq 0,05)$.

Fonte: elaborado pelos autores.

Tabela 2 - Rendimento do experimento em relação as lavouras (Maravilha/SC - Safra 2017)

\begin{tabular}{|c|c|}
\multicolumn{1}{|c}{ Local } & Rendimento \\
\hline Lavoura 1 & $41,02 \mathrm{a}$ \\
\hline Lavoura 2 & $40,68 \mathrm{a}$ \\
\hline CV (\%) & 18,04 \\
\hline
\end{tabular}

Médias seguidas de mesma letra não diferem entre si pelo teste de Tukey $(\mathrm{P} \leq 0,05)$.

Fonte: elaborado pelos autores.

A análise de variância revelou efeito significativo $(P \leq 0,05)$ do manejo da adubação nitrogenada e não significativo para as lavouras em relação às variáveis respostas receita, despesa e lucro (Tabelas 3 e 4).

Tabela 3 - Receita, despesa e lucro do experimento em relação ao manejo da adubação nitrogenada (Maravilha/SC - Safra 2017)

\begin{tabular}{|c|c|c|c|}
\multirow{2}{*}{$\begin{array}{c}\text { Manejo da adubação } \\
\text { nitrogenada }\end{array}$} & Receita & Despesa & Lucro \\
\cline { 2 - 4 } Manejo do produtor & $1110,20 \mathrm{~b}$ & $186,00 \mathrm{~b}$ & $924,20 \mathrm{~b}$ \\
\hline Manejo via RPA & $1609,78 \mathrm{a}$ & $139,50 \mathrm{a}$ & $1470,28 \mathrm{a}$ \\
\hline CV (\%) & 17,94 & 5,00 & 20,38 \\
\hline
\end{tabular}

Médias seguidas de mesma letra não diferem entre si pelo teste de Tukey $(\mathrm{P} \leq 0,05)$.

Fonte: elaborado pelos autores.

Tabela 4 - Receita, despesa e lucro do experimento em relação as lavouras (Maravilha/SC - Safra 2017)

\begin{tabular}{|c|c|c|c|}
\hline Local & Receita & $\begin{array}{l}\text { Despesa } \\
-(\mathrm{R} \$ / \mathrm{ha})\end{array}$ & Lucro \\
\hline Lavoura 1 & $1377,50 \mathrm{a}$ & $162,75 \mathrm{a}$ & $1214,75 a$ \\
\hline Lavoura 2 & $1342,49 a$ & $162,75 \mathrm{a}$ & $1179,73 \mathrm{a}$ \\
\hline CV (\%) & 17,94 & 5,00 & 20,38 \\
\hline
\end{tabular}

Médias seguidas de mesma letra não diferem entre si pelo teste de Tukey $(\mathrm{P} \leq 0,05)$.

Fonte: elaborado pelos autores. 
Conforme observado na Tabela 1, o rendimento da cultura do trigo manejada via RPA foi significativamente maior devido ao parcelamento das aplicações nitrogenadas, pois quando fracionadas as doses de $\mathrm{N}$ em perfilhamento e elongação de colmo, ocorre a definição dos componentes de rendimento, ou seja, o manejo georreferenciado via RPA envolve a obtenção e processamento de informações detalhadas sobre determinada área de cultivo de trigo, permitindo à definição de estratégias de manejo mais eficientes, em especial, no uso racional de insumos (adubação nitrogenada) de acordo com a sua ecofisiologia (EMBRAPA 2014).

0 rendimento não apresentou diferenças entre as lavouras (Tabela 2), pelo fato das mesmas estarem situadas dentro das mesmas condições edafoclimáticas (FIGURA 1).

No que diz respeito à dose de nitrogênio, a recomendação está relacionada, principalmente, à cultura anterior, teor de matéria orgânica do solo, condições climáticas, cultivar, dentre outros (FLOSS, 2011).

Como observado na Tabela 3, para a variável receita, o manejo via RPA (R \$ 1609,78 por hectare) diferiu significativamente do convencional ( $\mathrm{R} \$ 1110,20$ por hectare. Rendimentos em lavouras de trigo, e de outras culturas, são dependentes do manejo e das condições edafoclimáticas (FLOSS, 2011).

Em relação as despesas (TABELA 3) é possível perceber que o manejo via RPA apresenta significativamente os menores valores (R\$) quando comparado ao convencional. A leitura do teor de clorofila via RPA (leitura $S P A D$ ) é uma ferramenta tecnológica que proporciona ao agricultor, subsídio para verificar o desempenho da cultura do trigo (e outras), com adubação nitrogenada correlacionada com os seus estádios ontogênicos. 0 uso do SPAD viabiliza com rapidez e facilidade os resultados, permitindo ao agricultor aplicar apenas o exigido pela referida cultura, articulando aspectos técnicos, ecológicos, sociais e ambientais, proporcionando assim, a sustentabilidade do respectivo sistema de produção vegetal (HURTADO et al., 2008).

Como apresentado na Tabela 3, o lucro significativamente maior foi obtido no manejo via RPA, quando comparado ao convencional, pois neste manejo, a receita foi maior e a despesa foi menor em relação ao manejo convencional, obtendo uma diferença de $\mathrm{R} \$ 546,08$ a mais. Tal explicação deve-se ao manejo por RPA (índice $S P A D$ ), proporcionando uma melhor otimização do adubo nitrogenado (HURTADO et al., 2008).

Com base nos resultados técnicos e econômicos da respectiva pesquisa, pode-se perceber que em um determinado ambiente, a manifestação fenotípica é o resultado da ação do genótipo sob influência do ambiente. Entretanto, quando se considera uma série de ambientes, detecta-se, além dos efeitos de genótipos e de ambientes, um efeito adicional, proporcionado pela interação dos mesmos. Essa interação quantifica o comportamento diferenciado dos genótipos diante das variações ambientais e é denominada interação genótipos x ambientes (GxA) (CRUZ e REGAZZI, 1997; CRUZ e CARNEIRO, 2003).

\section{CONCLUSÃO}

Com este estudo, pode-se concluir que o manejo georreferenciado com RPA é mais eficaz em relação ao manejo convencional, considerando algumas tecnologias que permitem aplicar a quantidade necessária de nitrogênio, evitando desperdícios, obtendo assim mais eficiência das plantas na absorção deste nutriente ao longo do ciclo.

Pode-se concluir também que o manejo com RPA obteve maior lucratividade comparado ao manejo convencional, pelo fato de ter obtido menor despesa com adubação nitrogenada.

\section{AGRADECIMENTOS}

Programa PIBITI do Conselho Nacional de Iniciação Científica (CNPq), cotas 2017/2018.

\section{REFERÊNCIAS}

[1] Biotrigo. TBIO TORUK. 2014. Disponível em: <http://www.biotrigo.com.br/cultivares/internaCultivar.php?empresa=1\&id=32>. Acesso em: 06 jun. 2018.

[2] Cirani, C. B. S., Moraes, M. A. F. D. Inovação na Indústria Sucroalcooleira Paulista: Os Determinantes da Adoção das Tecnologias de Agricultura de Precisão. Disponível em: <http://www.scielo.br/pdf/resr/v48n4/a03v48n4.pdf >. Acesso em: 03 jul. 2018. 
[3] Comissão de Química E Fertilidade do Solo - CQFS - RS/SC. Manual de calagem e adubação para os Estados do Rio Grande do Sul e de Santa Catarina, 2016.

[4] Cruz, C. D.; carneiro, P. C. S. Modelos biométricos aplicados ao melhoramento genético. Viçosa: UFV, v. 2, 2003.

[5] Cruz, C. D.; Regazzi, A. J. Modelos biométricos aplicados ao melhoramento genético. 2. ed. Viçosa: UFV, 1997.

[6] Empresa Brasileira de Pesquisa Agropecuária - EMBRAPA. Sistema brasileiro de classificação de solos. 3.ed. Brasília, 2013.

[7] Empresa Brasileira de Pesquisa Agropecuaria - EMBRAPA. Influência do nitrogênio na qualidade do trigo. 2014. Disponível em: <https://www.embrapa.br/busca-de-noticias/-/noticia/2085244/influencia-do-nitrogenio-naqualidade-do-trigo>. Acesso em: 03 jul. 2018.

[8] Ferreira, D. F. Sisvar - Sistema de análise de variância. Versão 5.3. Lavras-MG: UFLA, 2010.

[9] Floss, E. L. Fisiologia das plantas cultivadas: o estudo do que está por trás do que se vê. 5. ed. Passo Fundo: UPF, 2011.

[10] Gómez-Candón, D. et al. Assessing the accuracy of mosaics from unmanned aerial vehicle (UAV) imagery for precision agriculture purposes in wheat. Precision Agriculture, v. 15, n. 1, p 44-56, fev. 2014. Disponível em: <http://link.springer.com/article/10.1007\%2Fs11119-013-9335-4>. Acesso $\quad$ em: $07 \quad$ jul. 2018. http://dx.doi.org/10.1007/s11119-013-9335-4.

[11] Hurtado, S. M. C. et al. Agricultura de Precisão: possibilidades de manejo da adubação nitrogenada para o milho no Cerrado. Embrapa, Planaltina, v. 1, n. 214, p. 9-37, maio, 2008 . Disponível em: <http://www.infoteca.cnptia.embrapa.br/handle/doc/556775>. Acesso em: 03 jul. 2018.

[12] Instituto Nacional de Meteorologia - INMET. Estações e Dados, 2018. Disponível em: < http://www.inmet.gov.br/portal/> Acesso em: 10 jun. 2018.

[13] Mattuella, D.; Simioni, S. P. Eficiência agronômica da cultura do trigo (Triticum aestivum L.) submetida a doses de nitrogênio em diferentes estádios ontogênicos. 2015. 59 f. Trabalho de Conclusão de Curso (Graduação em Agronomia), Universidade do Oeste de Santa Catarina (Unoesc), São José do Cedro, 2015.

[14] Ministério da Agricultura, Pecuária e Abastecimento - MAPA. Regras para Análise de Sementes, 2009.

[15] Monteiro, M. A. Caracterização climática do estado de Santa Catarina: uma abordagem dos principais sistemas atmosféricos que atuam durante o ano. Geosul, Florianópolis, v. 16, n. 31, p. 69-78, jan./jun. 2001.

[16] Mendonça, Francisco; Danni-Oliveira, Inês Moresco;. Climatologia noções básicas e climas do Brasil. São Paulo: Oficina de Textos, 2007.

[17] Mundstock, C. M. Quando aplicar o nitrogênio em trigo, cevada e aveia. 2005. Disponível em: <file://C:/Users/Fabio/Downloads/folder_trigo.pdf>. Acesso em: 06 jun. 2018.

[18] Primicerio, J. et al. A flexible unmanned aerial vehicle for precision agriculture. Precision Agriculture, v. 13, n. 4, p. 517-523, jan, 2012. Disponível em: < http://link.springer.com/article/10.1007\%2Fs11119-012-9257-6>. Acesso em: 06 jun. 2018.

[19] Zhang, C.; Kovacs, J. M. The application of small unmanned aerial systems for precision agriculture: a review. Precision Agriculture, v. 13, n. 6, p. 693-712, jul. 2012. Disponível em:

<http://link.springer.com/article/10.1007\%2Fs11119-012-9274-5>. Acesso em: 29 fev. 2018.

http://dx.doi.org/10.1007/s11119-012-9274-5. 


\title{
Capítulo 6
}

\section{Manejo da fertirrigação nitrogenada na cultura do alho-poró}

\author{
Karoline Kovaleski Bertoldo Drehmer \\ Cristiane Dalagua Paier \\ Guilherme Augusto Bíscaro \\ Luciano Oliveira Geisenhoff \\ Gabriel Queiroz de Oliveira \\ Alice Rodrigues de Souza \\ Luciana Aparecida Maurício da Silva \\ Paulo Sergio Vieira Filho
}

Resumo: 0 trabalho teve como objetivo verificar o efeito das doses de nitrogênio (N), aplicadas em fertirrigação sobre a produtividade da cultura do alho-poró. 0 estudo foi realizado na Faculdade de Ciências Agrárias da Universidade Federal da Grande Dourados, sob um Latossolo Vermelho distroférrico. 0 experimento foi realizado entre os meses de abril e setembro de 2017. Os tratamentos foram constituídos de quatros doses de N, zero, 100, 200 e $300 \mathrm{~kg} \mathrm{ha}^{-1}$ aplicados em fertirrigação nos 15, 30 e 45 dias após o transplantio das mudas (DAT). 0 delineamento experimental utilizado foi o de blocos casualizados, com oito repetições. A cultivar utilizada foi "Carentan" e o transplantio ocorreu 61 dias após semeadura e a colheita 103 DAT. As variáveis analisadas foram: produtividade total de matéria fresca e seca e a produtividade do pseudocaule fresco e seco. Os dados foram submetidos à análise de variância $(p \leq 0,05)$, e à análise de regressão para verificar o efeito do $\mathrm{N}$ nas características avaliadas. A aplicação de $\mathrm{N}$ em fertirrigação mostra-se significativa em relação à produtividade do alho-poró. Todos os parâmetros avaliados ajustam-se ao modelo de regressão linear crescente, no entanto, não se obteve maior produtividade com as doses testadas.

Palavras-chave: Allium ampeloprasum L., umidade do solo; gotejamento. 


\section{INTRODUÇÃO}

O alho-poró (Allium ampeloprasum L.) também conhecido como alho-porro ou alho-francês pertence ao grupo das hortaliças de bulbos e à família das Aliáceas, a mesma do alho, cebola e cebolinha. É cultivada em praticamente todo o planeta e no Brasil tem a produção concentrada nos Estados da região Sul e Sudeste (Embrapa, 2010).

Cada espécie de hortaliça tem uma diferente parte comercializada e consumida, podendo dividi-las em grupos. Nos grupos de hortaliças de bulbos e subterrâneas, a parte comercializada e consumida são bulbos, caules e raízes, dessa maneira a produção de todas as diferentes espécies de hortaliças, que normalmente são feitas sob condições de cultivo intensivo, existe a necessidade de adequado suprimento de nutrientes desde o estádio de plântula até a colheita, haja vista que, o desequilíbrio nutricional, seja por carência ou excesso de nutrientes, é fator estressante para a planta (Furlani; Purquerio, 2010).

A nutrição mineral de plantas é a área do conhecimento envolvida com o estudo dos elementos químicos necessários à planta para complementar o seu ciclo e, a raiz adquire, absorve, regula e transporta os nutrientes de forma integrada com a parte aérea, em processos extremamente bem coordenados, mas ainda pouco conhecidos (Fontes, 2014).

$\mathrm{O}$ nitrogênio $(\mathrm{N})$ é um dos nutrientes essenciais para as plantas, por ser constituinte de compostos bioquímicos na célula vegetal, importante na formação de proteínas, aminoácidos e de outros compostos importantes no metabolismo das plantas (Kunz et al., 2009). Segundo Biscaro (2014), quando uma planta está bem suprida de $\mathrm{N}$ ela apresenta coloração verde escura (devido à maior presença de clorofila), maior quantidade de galhos e folhas e maior brotação. Na deficiência de $\mathrm{N}$, a planta apresenta menor desenvolvimento vegetativo e sintomas de clorose (estado da planta no qual as folhas não produzem clorofila suficiente), com as folhas apresentando uma coloração verde pálida ou mesma amarelada. No entanto, se aplicado em excesso, o $\mathrm{N}$ pode ocasionar o retardamento na manutenção e um crescimento exagerado da planta.

Por ser do mesmo gênero da cebola o sistema de irrigação que melhor se adapta ao alho-poró é a irrigação por gotejamento por possuir as melhores condições de proporcionar alto controle e alta uniformidade na aplicação de água sob diferentes condições agroclimáticas, garantindo qualidade e bons rendimentos (Pérez-Ortolá et al., 2015). Existem diversas formas para realizar a adubação, no entanto, quando se faz uso de irrigação por gotejamento, a maneira de melhor emprego é a fertirrigação, na qual se realiza a aplicação de fertilizante (solúveis ou líquidos) na água de irrigação, em substituição à adubação convencional, com o objetivo de aumentar a eficiência no fornecimento de nutrientes para as plantas através de práticas de parcelamentos e reduzir os custos com mão de obra e fertilizantes (Biscaro, 2014).

0 uso da fertirrigação no cultivo de hortaliças tem trazido aumentos em produtividade e melhoria das características comerciais e de qualidade dos produtos. Entretanto, para que estes resultados sejam mantidos ao longo dos anos, é necessário que a fertirrigação seja praticada de forma tecnicamente segura, levando em consideração todos os fatores que influenciam a fisiologia e a nutrição das plantas, e a fertilidade do solo, a fim de se obter sucesso agronômico, sem riscos ambientais, como a salinização e a contaminação dos recursos hídricos (Embrapa, 2004).

Visando contribuir com informações sobre manejo da adubação com $\mathrm{N}$ na cultura do alho-poró, em consequência da carência de estudos, este trabalho teve como objetivo verificar o efeito das doses de $\mathrm{N}$, aplicadas em fertirrigação, na produtividade da cultura do alho-poró.

\section{MATERIAL E MÉTODOS}

0 trabalho foi realizado entre os meses de abril e setembro de 2017, na área experimental de Irrigação e Drenagem da Faculdade de Ciências Agrárias da Universidade Federal da Grande Dourados, localizado a latitude de $-22^{\circ} 13^{\prime} 16^{\prime \prime}$, longitude de -54ำ17'01" e altitude de $430 \mathrm{~m}$.

O clima, segundo Köppen, é do tipo Cwa, ou seja, mesotérmico úmido com precipitações e temperaturas médias anuais variando entre 1250 a $1500 \mathrm{~mm}$ e $20{ }^{\circ} \mathrm{C}$ a $24{ }^{\circ} \mathrm{C}$ (FIETZ et al., 2017). Os dados meteorológicos foram coletados da estação automática do Instituto Nacional de Meteorologia (INMET) no município de Dourados, MS. As temperaturas máximas e mínimas e a umidade relativa do ar ocorridas no período do experimento, bem como a precipitação pluviométrica estão apresentadas na Figura 1. 
Figura 1. Dados climáticos entre o período 11/06/2017 a 23/09/2017.

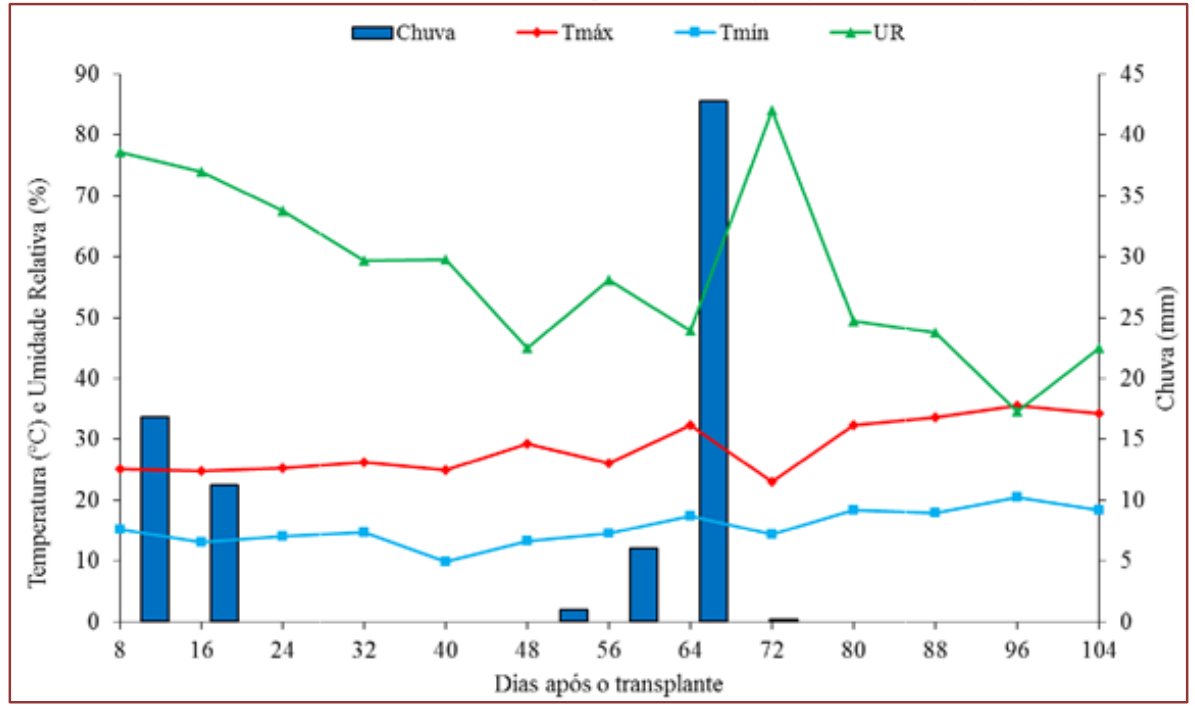

O solo da área experimental é classificado como Latossolo Vermelho distroférrico (Emprapa, 2013). Para a determinação das características químicas do solo, foram coletadas amostras em profundidades de 0-20 cm, conforme a metodologia da Embrapa (2017) (Tabela 1).

Tabela 1. Análise química do solo da área experimental para a camada de 0-20 cm.

\begin{tabular}{|c|c|c|c|c|c|c|c|c|c|c|c|}
\hline $\mathrm{pH}^{*}$ & $\begin{array}{c}\mathrm{P} \\
\mathrm{mg} \mathrm{dm}^{-3}\end{array}$ & $\begin{array}{c}\mathrm{M} . \mathrm{O} \\
\mathrm{g} \mathrm{dm}^{-3}\end{array}$ & $\mathrm{~K}$ & $\mathrm{Al}$ & $\mathrm{Ca}$ & $\mathrm{Mg}$ & $\mathrm{H}+\mathrm{Al}$ & $\mathrm{SB}$ & $\mathrm{T}$ & $\mathrm{V}$ \\
$\mathrm{cmolc} \mathrm{dm}-3$ & & & \\
\hline 5,8 & 31,1 & 26,7 & 4,15 & 0,0 & 6,95 & 2,6 & 4,0 & 13,7 & 17,7 & 78 \\
\hline
\end{tabular}

A adubação da cultura baseou-se no resultado da análise de solo e seguindo as recomendações de Raij (2011). A calagem foi realizada 30 dias antes da semeadura, para elevar para $80 \%$ a saturação por bases, utilizando o calcário dolomítico com PRNT 75\%.

A semeadura do alho-poró, cultivar "Carentan" foi realizada no dia 11 de abril, em bandejas de isopor com 128 cavidades cada, preenchidas com substrato comercial (Seixos Terra Nova ${ }^{\circledR}$ ), mantidas em casa de vegetação e regadas diariamente.

Os canteiros com dimensões de $16 \mathrm{~m}$ de comprimento e $1 \mathrm{~m}$ de largura cada foram preparados com enxada rotativa. 0 tamanho das parcelas foi de $2 \times 1 \mathrm{~m}$. 0 transplantio foi realizado dois meses após a semeadura, de acordo com a recomendação feita por Filgueira (2013), com espaçamento de 0,20 m entre linha e $0,20 \mathrm{~m}$ entre plantas. Realizou-se a amontoa três vezes durante o ciclo (50,100 e 150 dias) para provocar o estiolamento do pseudocaule comestível, para torná-lo branco.

0 delineamento experimental utilizado foi o de blocos casualizados com oito repetições. Os tratamentos foram constituídos por quatro doses de nitrogênio $\left(0,100,200\right.$ e $\left.300 \mathrm{~kg} \mathrm{ha}^{-1}\right)$, cujo a fonte foi a ureia (45\%), aplicadas de forma parcelada via fertirrigação aos 15, 30 e 45 dias após o transplantio (DAT). Considerou-se como área útil de cada parcela, a linha central e como bordadura as duas linhas externas.

0 sistema de irrigação adotado foi por gotejamento, com fitas gotejadoras da marca Petrodrip ${ }^{\circledR}$, modelo Manari, com espaçamento de 0,20 m entre emissores, vazão de 1,5 $\mathrm{L} \mathrm{h}^{-1}$, com pressão de serviço de $10 \mathrm{~m}$ c.a. sendo instalada três linhas por canteiro, juntamente com as linhas de cultivo. 0 manejo da irrigação foi realizado com turno de rega de dois dias, com o auxílio do sensor de umidade volumétrica, o "Hidrofarm" (Falker, 2010; Gomes et al., 2013) que possibilita a determinação do teor de água através da impedância do solo e alta frequência.

A lâmina de irrigação foi calculada conforme a Equação 1. 


$$
L L=(\theta c c-\theta a) Z
$$

Onde:

LL- Lâmina líquida (mm); $\theta \mathrm{cc}$ - Umidade do solo na capacidade de campo $\left(0,3896 \mathrm{~cm}^{3} \mathrm{~cm}^{-3}\right.$; potencial mátrico: $10 \mathrm{kPa})$; $\theta \mathrm{a}$ - umidade atual $\left(\mathrm{cm}^{3} \mathrm{~cm}^{-3}\right)$ fornecida pelo Hidrofarm e Z - profundidade do sistema radicular.

0 tempo de irrigação foi baseado na lâmina bruta, considerando o sistema de gotejamento com eficiência de $90 \%$ (Bernardo et al., 2006).

A colheita foi realizada aos 164 dias após a semeadura (DAS). Avaliou-se seis plantas centrais por parcela e as seguintes variáveis, produtividade total de matéria verde (folhas e pseudocaule) e a produtividade do pseudocaule.

Os dados foram submetidos a análise de variância $(\mathrm{p} \leq 0,05)$, e à análise de regressão para verificar o efeito do N nas características avaliadas, utilizando-se o programa estatístico Sisvar, versão 5.6 (Ferreira, 2011).

\section{RESULTADOS E DISCUSSÃO}

A lâmina líquida total foi de aproximadamente $1.366 \mathrm{~mm}$ (irrigação e chuva), sendo que, 73,5 mm foi referente a chuva do período descrito na Figura 1.

Conforme os dados apresentados na análise de variância (Tabela 2), pode-se observar que houve efeito significativo de doses de nitrogênio via fertirrigação para as variáveis produtividade total e produtividade do pseudocaule.

Tabela 2. Resumo da análise de variância da produtividade total de matéria fresca (PTF), produtividade do pseudocaule fresco (PPF), produtividade total de matéria seca (PTS) e produtividade do pseudocaule seco (PPS) do alho-poró.

\begin{tabular}{|l|c|c|c|c|}
\multicolumn{1}{c|}{ Fonte de Variação } & PTF & PPF & PTS & PPS \\
\hline Nitrogênio & $58330^{*}$ & $5110^{*}$ & $571^{*}$ & $71^{*}$ \\
\hline Bloco & 1890 & 1990 & 30 & 5 \\
\hline Resíduo & 1530 & 129 & 30 & 3 \\
\hline CV (\%) & 20,22 & 21,16 & 26,94 & 25,83 \\
\hline Média & 6119 & 1699 & 646 & 225 \\
\hline
\end{tabular}

Significativo a $5 \%$ de probabilidade pelo teste F., CV - coeficiente de variação.

Verifica-se na Figura 2A, que a variável produtividade total ajustou-se ao modelo de regressão linear em relação ao aumento das doses de $\mathrm{N}$, possibilitando o aumento de $11.235 \mathrm{~kg} \mathrm{ha}^{-1}$ para $35.392 \mathrm{~kg} \mathrm{ha}^{-1}$, cujo incremento foi de $215 \%$ com a adição de $300 \mathrm{~kg} \mathrm{ha}^{-1}$ de N. Não se pôde aferir a maior produtividade total de matéria verde através das doses de nitrogênio testadas, no entanto, com a equação do modelo de regressão, verifica-se o aumento de $84,213 \mathrm{~kg} \mathrm{ha}^{-1}$ de produtividade total para cada quilograma de $\mathrm{N}$ aplicado em fertirrigação.

Rezende e Souza (2001) observaram aumento na produtividade total de alho em função a aplicação de doses crescentes de $\mathrm{N}$, correlacionando de maneira quadrática, sendo a dose de $\mathrm{N}$ de $149,2 \mathrm{~kg} \mathrm{ha}^{-1}$ foi a que proporcionou a maior produtividade total de bulbos de alho, entretanto, Macêdo et al. (2009) em estudo realizado no município de Lavras, estudando o efeito do nitrogênio com dose máxima de $180 \mathrm{~kg}$ ha${ }^{1}$ para a cultura do alho observaram aumento linear na produtividade de alho em função a aplicação de doses crescentes de $\mathrm{N}$.

A produtividade do pseudocaule fresco aumentou de forma linear com o aumento das doses de $\mathrm{N}$ (Figura 2B). Observou-se acréscimos de $2.529,6.546$ e $6.937 \mathrm{~kg} \mathrm{ha}^{-1}$ na produtividade comercial de matéria verde com o uso de 100, 200 e $300 \mathrm{~kg} \mathrm{ha}^{-1}$ de $\mathrm{N}$, respectivamente, comparado com o tratamento sem $\mathrm{N}$. Do mesmo modo que a produtividade total, não se pôde verificar a maior produtividade, contudo, a dose de $300 \mathrm{~kg} \mathrm{ha}^{-1}$ de N proporcionou a produtividade do pseudocaule na ordem de $10.013 \mathrm{~kg} \mathrm{ha}^{-1}$. 
Kiffo et al. (2016) verificaram que a produtividade total e do pseudocaule do alho-poró foram influenciados pelas doses de $\mathrm{N}$, sendo que a produtividade total mostrou tendência crescente com aumento com as doses de $\mathrm{N}$, com produtividade na ordem de $48.630 \mathrm{~kg} \mathrm{ha}^{-1}$ com aplicação de $138 \mathrm{~kg} \mathrm{ha}^{-1}$ de N. O nitrogênio é o principal componente de muitos compostos vegetais essenciais e é necessário para formar clorofila, proteínas, aminoácidos e muitas outras moléculas essenciais para o crescimento das plantas e outros componentes críticos das plantas e ácidos nucleicos (Taiz; Zeiger, 2013).

Figura 2. Produtividade total de massa fresca do pseudocaule fresco de alho-poró submetido a adubação nitrogenada por fertirrigação
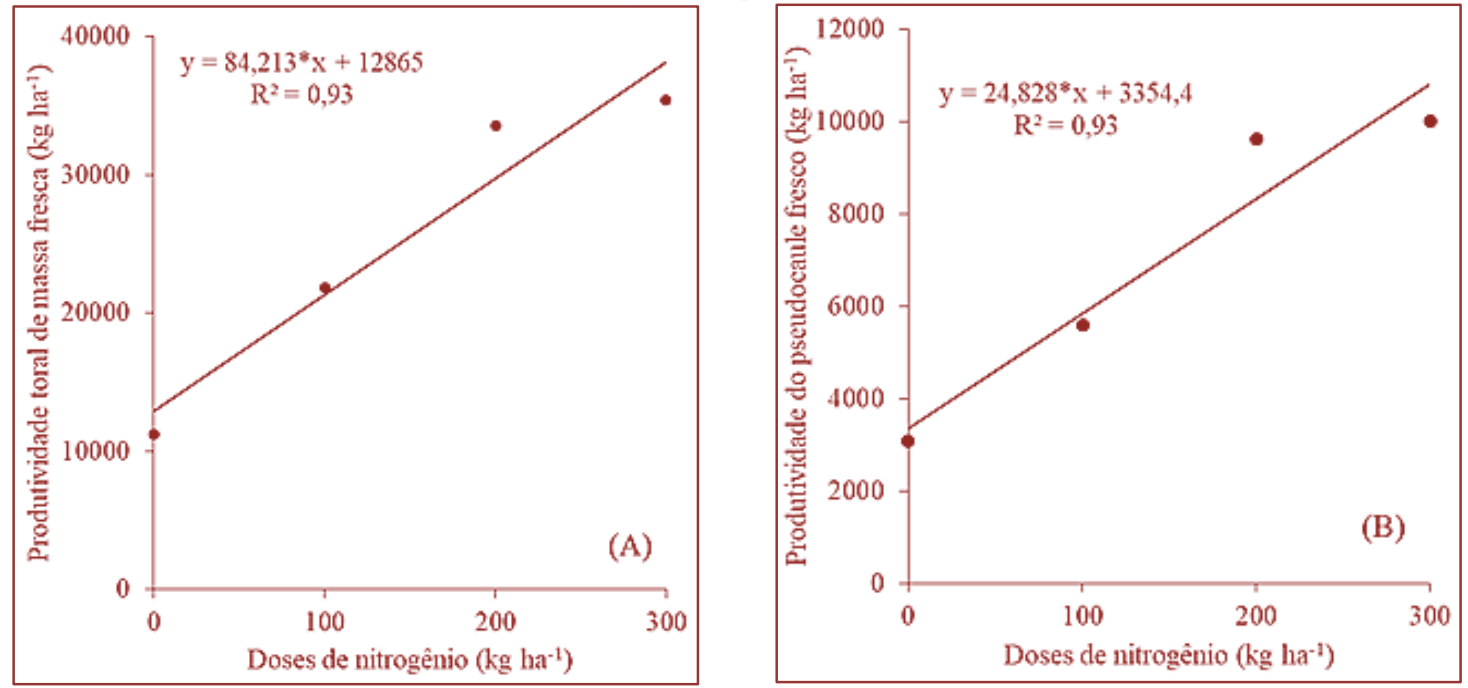

Segundo Nielsen e Thorup-Kristensen (2001), as raízes de alho-poró podem crescer rapidamente a uma profundidade de cerca de 0,4 $\mathrm{m}$, com uma alta densidade de raízes diretamente abaixo da linha de alhoporó, e ainda os autores salientaram que os resultados mostram ser possível estabelecer a cultura o alhoporó, minimizando o risco de lixiviação de $\mathrm{N}$, sem que o rendimento da cultura possa ser comprometido.

A produtividade total de massa seca ajustou-se ao modelo de regressão linear em função da adubação nitrogenada (Figura 3A). As doses de 100, 200 e $300 \mathrm{~kg}$ ha-1 de N proporcionaram incrementos de 1.017, 2.177 e $2.404 \mathrm{~kg}$ ha-1, comparado com a dose sem N. Diante disso do modelo de regressão pode aferir que produtividade total de matéria seca aumenta na ordem de 8,37 kg para cada quilograma de $\mathrm{N}$ aplicado. Dessa maneira estima-se que a maior produtividade total de massa seca foi de $3.946 \mathrm{~kg} \mathrm{ha-1}$

Figura 3. Produtividade total de massa seca do pseudocaule seco de alho-poró submetido a adubação nitrogenada por fertirrigação. * Significativo a 5\% de probabilidade pelo teste $t$.
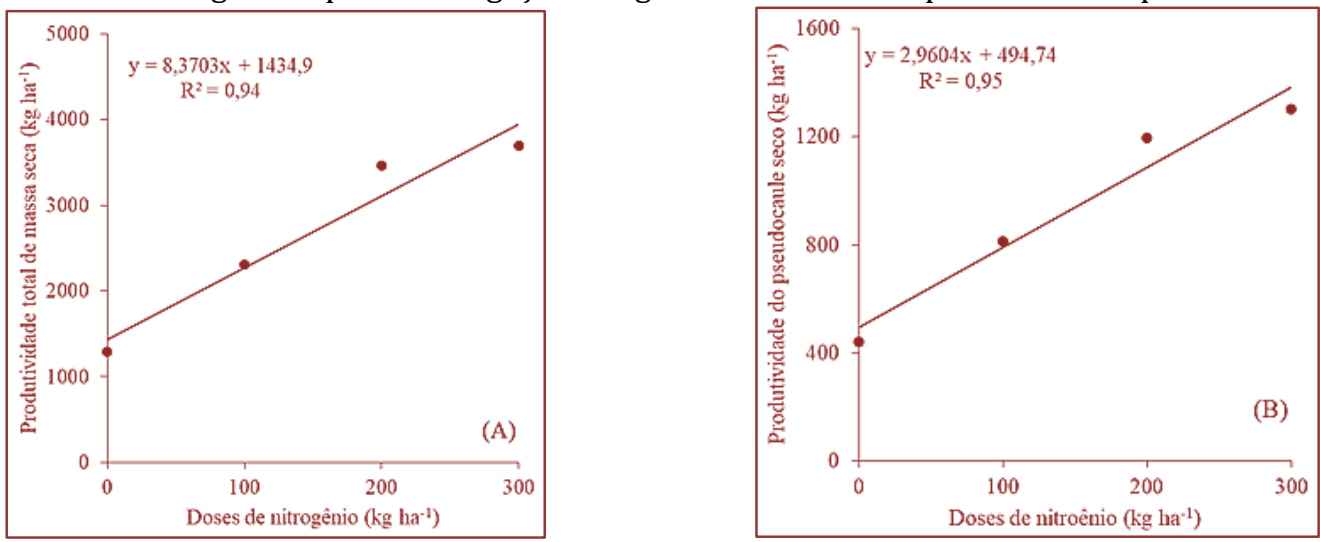
A produtividade do pseudocaule seco ajustou-se ao modelo de regressão linear com o aumento das doses de N (Figura 3B). Com as doses de 100, 200 e $300 \mathrm{~kg} \mathrm{ha}^{-1}$ de N, observou-se acréscimos de 373, 756 e 859 kg ha-1 respectivamente, comparado com a área sem acréscimo de N. Da mesma forma, Raupp (2005) indicou que a fertilização nitrogenada não afetou o teor de matéria seca do pseudocaule. 0 mesmo foi relatado por Kiffo et al. (2016), onde as doses de nitrogênio aplicadas (dose máxima de $138 \mathrm{~kg}^{\mathrm{ha}}{ }^{-1}$ ) não tiveram efeito significativo no teor de matéria seca do alho-poró. Apesar disso, os mesmos relataram tendência para o teor de matéria seca diminuir levemente à medida que o nível de $\mathrm{N}$ foi aumentado e apontaram que uma taxa mais alta de fertilizantes nitrogenados tendem a diminuir o teor de matéria seca nos vegetais.

Segundo Souza e Casali (1986), o N é o constituinte de importantes compostos bioquímicos da célula vegetal, como os nucleotídeos que formam a estrutura dos ácidos nucleicos e os aminoácidos que formam as proteínas (Taiz; Zeiger, 2013).

Cecílio Filho et al. (2009) salientaram que plantas não adubadas com N apresentaram taxas de acúmulo de matéria seca crescentes até a colheita, ou seja, taxas de 37,7; 51,8 e 63,2 mg por planta por dia nos períodos de 40 a 80, 80 a 120 e 120 a 150 dia após a semeadura (DAS) e verificaram que houve significância da matéria seca a partir 110 DAS. Isso se deve pelo fato da cebola apresentar crescimento lento até próximo à metade do ciclo (Vidigal et al., 2002).

\section{CONCLUSÃO}

A produtividade do alho-porró é influenciada significativamente pelas doses de nitrogênio em fertirrigação.

A adubação nitrogenada aumenta a produtividade total de massa fresca e seca, bem como a produtividade de massa fresca e seca de pseudocaule.

\section{REFERÊNCIAS}

[1] Bernardo, S.; Soares, A. A; Mantovani, E. C. Manual de irrigação. 8. ed. Viçosa: Editora UFV, 2006. 625p.

[2] Biscaro, G.A. Sistema de Irrigação Localizada. 1o ed. Editora UFGD, Dourados, 2014. 256p.

[3] Cecílio Filho AB; May A; Pôrto DRQ; Barbosa JC. 2009. Crescimento da cebola em função de doses de nitrogênio, potássio e da população de plantas em semeadura direta. Horticultura Brasileira 27: 049-054.

[4] Embrapa. Manual de métodos de análise de solo. 3ª̣ ed. Brasília. Embrapa Solos. 577 p. 2017.

[5] Embrapa. Fertirrigação de hortaliças. Brasília. 13 p, 2004 . Disponível em: <https://www.infoteca.cnptia.embrapa.br/bitstream/doc/778699/1/ct32.pdf>. Acesso em: 25 de agosto de 2019.

[6] Embrapa - Centro Nacional de Pesquisa de Solos. Sistema brasileiro de classificação de solos. 3. ed. Rio de Janeiro: Embrapa Solos, 2013. 353 p.

[7] Embrapa. Catálogo Brasileiro de Hortaliças: Saiba como plantar e aproveitar 50 das espécies mais comercializadas no país. Brasília. Embrapa Hortaliças. 60 p, 2010 . Disponível em:< http://www.ceasa.gov.br/dados/publicacao/Catalogo\%20hortalicas.pdf >. Acesso em: 24 de fevereiro de 2019.

[8] Falker. Quais as diferenças do Hidrofarm para sensores como o Watermark, 2011. Disponível em:<http://www.falker.com.br/base/article/AA-00327>. Acesso em: 24 de fevereiro de 2019.

[9] Ferreira, D. F.Sisvar: um sistema computacional de análise estatística. Ciência e Agrotecnologia, v.3, 2011. Disponível em: <http://www.scielo.br/scielo.php? script=sci_arttext\&pid=S1413-70542011000600001>. Acesso em: 25 de outubro de 2018.

[10] Fietz, C. R.; Fisch, G. F.; Comunello, é. Flumignan, D. L. O Clima da Região de Dourados, MS. 3o Edição. Dourados, MS: Embrapa Agropecuária Oeste, 2017.31p. (Documentos / Embrapa Agropecuária Oeste).

[11] Filgueira,F. A. R. Novo manual de Olericultura: Agrotecnologia moderna na produção e comercialização de hortaliças. 3 ed. Viçosa: UFV. 421p, 2013.

[12] Fontes, P.C.R. Nutrição mineral de hortaliças: horizontes e desafios para um agrônomo. Horticultura Brasileira, v. 32, n. 3, p. 247-253, $2014 . \quad$ Diponivel em <http://www.scielo.br/scielo.php?script=sci_arttext\&pid=S010205362014000300247\&lng=en\&nrm=iso>. Acesso em: 21 de setembro de 2019. http://dx.doi.org/10.1590/S0102-05362014000300002. 
[13] Furlani, P.R.; Purquerio, L.F.V. 2010. Avanços e desafios na nutrição de hortaliças.Disponívelem:<http://www.abhorticultura.com.br/biblioteca/arquivos/Download/ biblioteca/Desafios_2010.pdf >. Acesso em: 25 de novembro de 2018.

[14] Gomes, E.P.; Oliveira, G.Q. de; Schwerz, F.; Silva, P.A. da; Biscaro, G.A.; Couto, R.S. Avaliação do medidor eletrônico de umidade do solo "Hidrofarm" em Latossolo vermelho distroférrico. Revista Brasileira de Agricultura Irrigada v.7, n.1, 2013. Disponível em:<http://www.inovagri.org.br/revista/index.php/rbai/article/view/140/ pdf_126>. Acesso em 23 de fevereiro de 2019.

[15] Kiffo, B.L.; Tsadik, K.W.; Tana, T. Yield and yield components of leek (Allium ampeloprasum var. porrum L.) as influenced by levels of nitrogen fertilizer and population density at Areka, Southern Ethiopia. Journal of Biology, Agriculture and Healthcare, v. 6, n. 15, p. 21-33, 2016.

[16] Kunz, V.L.; Sirtoli LF, Furlan L.; Poletti, L.; Primo, M.A.; Rodrigues, J. D. Produtividade de cebola sob diferentes fontes e modos de aplicação de adubos nitrogenados em cobertura. Revista Biodiversidade, v.8, n.1, 31-37, 2009.

[17] Macêdo, F.S.; Souza, R.J.; Carvalho, J.G.; Santos, B.R.; Leite, L.V.R. Produtividade de alho vernalizado em função de doses de nitrogênio e molibdênio. Bragantina, v. 68, n. 3, p.657-663, 2009.

[18] Nielsen, K.L.; Thorup-Kristensen, K. Root growth and nitrogen utilization of a leek crop and an undersown catch crop. In: Horst W.J. et al. (eds) Plant Nutrition. Developments in Plant and Soil Sciences, v. 92. p. 1010-1011, 2002. Springer, Dordrecht

[19] Pérez-Ortolá, M.; Daccache, A.; Hess, T.M.; KNOX, J.W. Simulating impacts of irrigation heterogeneity on onion (Allium cepa L.) yield in a humid climate. Irrigation Science, v. 33, n. 1, p. 1-14, 2015.

[20] Raij, B. Fertilidade do solo e manejo de nutrientes. Piracicaba: Internacional Plant Nutrion Institute (IPNI). 2011. 420p.

[21] Raupp, J. Fertilization effects on products quality and examination of parameters and methods for quality assessment. Darmstadt, 2000. Disponível em:<http://http://www.edis.ifas.ufl.edu. Acesso em 07 de agosto de 2019.

[22] Resende GM; Souza RJ. 2001. Doses e épocas de aplicação de nitrogênio sobre a produtividade e características comerciais de alho. Horticultura Brasileira 19: 126-129.

[23] Souza, R.J.; Casali, V.W.D. Pseudoperfilhamento - uma anormalidade genéticofisiológica em alho. Informe Agropecuário, v.12, p. 36-41, 1986.

[24] Taiz, L.; Zeiger, E. Fisiologia vegetal. Porto Alegre, Artmed, 918 p, 2013.

[25] Vidigal, S.M.; Pereira, P.R.G.; Pacheco, D.D. Nutrição mineral e adubação de cebola. Informe Agropecuário, v. 23 , n. 218, p. 36-50, 2002. 


\section{Capítulo 7}

Análise do carbono orgânico no solo em lote irrigado com repolho na Região Agreste de Pernambuco-PE

\section{Eduardo Silva dos Santos}

Abelardo Antônio de Assunção Montenegro

Luiz Guilherme Medeiros Pessoa

Job Teixeira de Oliveira

Plinio Antonio Guerra Filho

Carlos Augusto Alves Cardoso Silva

Eduardo Arouche da Silva

Ana karla da Silva Oliveira

Resumo: 0 objetivo do trabalho foi analisar o quantitativo de Carbono Orgânico Total (COT) e Estoque de Carbono Orgânico Total (ECOT) do solo cultivado com repolho em lote irrigado no semiárido. 0 estudo foi realizado no município de Pesqueira, região Agreste de Pernambuco. Os tratamentos foram arranjados em delineamento de blocos ao acaso, em esquema $4 \times 2$, correspondendo a quatro fontes de adubação e dois tipos de cobertura do solo (ausência de cobertura morta e presença com densidade de $9 \mathrm{t} \mathrm{ha}^{-1}$ ), com quatro repetições. As quatro adubações foram: adubação organomineral (Takamix OM); adubação mineral (Uréia, Superfosfato simples e cloreto de potássio); adubação orgânica (20 t ha-1 de esterco de curral) e sem adubação (testemunha). Foi realizada duas amostragens de solo, aos 19 e 79 dias após transplante (DAT), nas profundidades de 0-0,20 e 0,20-0,40 m para a determinação do COT e ECOT. Os dados foram analisados com base nas significâncias das análises de variância, pelo teste $\mathrm{F}$ e das médias comparadas pelo teste $\mathrm{t}$ a $5 \%$ de probabilidade. Só houve efeito significativo para as profundidades analisadas, aos 19 DAT a média do COT foi de 11,1 e $8,8 \mathrm{~g} \mathrm{~kg}^{-1}$ e aos 79 DAT esta média foi de 10,2 e 7,7 $\mathrm{g} \mathrm{kg}^{-1}$, para as profundidades de 0-0,2 e 0,2-0,4 m, respectivamente. Para ECOT, nas profundidades avaliadas, houve redução de 20,89 e $24,92 \%$ aos 19 e 77 DAT, respectivamente.

Palavras-Chave: Materia orgânica, Produção, Manejo. 


\section{INTRODUÇÃO}

O repolho (Brassica oleracea var. capitata) é uma hortaliça herbácea, com folhas arredondadas e cerosas, formando uma cabeça compacta. Ao longo do tempo, foram obtidas cultivares adaptadas a temperaturas elevadas, ampliando consequentemente os períodos de plantio e de colheita (FILGUEIRA, 2008).

No tocante, Santos et al (2016) avaliando a produção de um híbrido de repolho em condições edafoclimáticas de região semiárida, verifiram produções médias do peso de cabeça e produção do repolho da ordem de 1247,88 g e 62,39 t ha-1 ${ }^{-1}$ demostrando uma alta adaptabilidade as condições locais para a cultura.

O carbono orgânico do solo (COS) é o principal componente da matéria orgânica do solo (MOS), recebendo grande atenção por sua importância na fertilidade e demais atributos do solo, bem como por seu potencial como mitigador parcial de emissões antropogênicas de CO2 (LAL, 2008). Entretanto, o estudo do COS é complexo devido à sua ampla variação no ambiente, pois sua quantidade e qualidade são funções de fatores externos (relevo, clima, vegetação e uso da terra) e internos ao solo, como textura, mineralogia e estrutura (RESCK et al., 2008).

Essa variabilidade também é acrescida pelo fato de que teores e composição funcional do COS variam muito em profundidade (RUMPEL \& KÖGEL-KNABNER, 2011), refletindo o balanço entre quantidades de C aportado e estabilizado.

Apesar da importância do carbono no solo, há escassez generalizada de dados sobre o comportamento dos teores de COS ao longo do perfil do solo dificultando a estimativa de estoques regionais de COS e a compreensão da sorção de íons na zona de vadosa, entre outros processos. Nesse sentido, o trabalho objetivou-se em analisar o quantitativo de Carbono orgânico total (COT) e Estoque de carbono orgânico total (ECOT) do solo cultivado com repolho em lote irrigado no semiárido Pernambucano.

\section{MATERIAL E MÉTODOS}

O estudo foi realizado no município de Pesqueira, região Agreste de Pernambuco, no Assentamento Rural

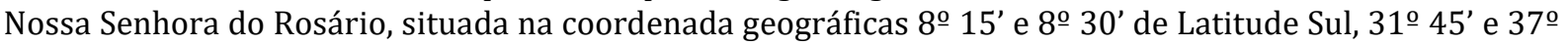
00 ' de Longitude Oeste de Greenwich. 0 clima é semiárido muito quente (Bsh), segundo Köppen. A precipitação média anual é de $607 \mathrm{~mm}$, a temperatura média é de $23^{\circ} \mathrm{C}$ e a evapotranspiração potencial é de cerca de $2.000 \mathrm{~mm}$ por ano (MONTENEGRO \& MONTENEGRO, 2006). 0 solo é caracterizado como Neossolo Flúvico, cujos valores da granolometria, densidade, umidade na capacidade de campo e no ponto de murcha permanente encontram-se na Tabela 1.

Tabela 1. Composição da granulometria e densidade do solo nas camadas de 0-0,20 e 0,20-0,40 m

\begin{tabular}{ccc|c|c|c|c|c|}
$\begin{array}{c}\text { Profundidade } \\
(\mathrm{m})\end{array}$ & Argila & $\begin{array}{c}\text { Silte } \\
\left(\mathrm{g} \mathrm{kg}^{-1}\right)\end{array}$ & Areia & Classe textural & $\begin{array}{c}\text { Ds } \\
\left(\mathrm{g} \mathrm{cm}^{-3}\right)\end{array}$ & $\begin{array}{c}\Theta_{\mathrm{cc}} \\
\left(\mathrm{cm}^{3} \mathrm{~cm}^{-3}\right)\end{array}$ \\
\hline $0-0,20$ & 149,68 & 515,39 & 334,83 & Franco siltoso & 1,52 & 0,27 & 0,12 \\
\hline $0,20-0,40$ & 169,79 & 492,10 & 345,28 & Franco & 1,49 & 0,25 & 0,11 \\
\hline
\end{tabular}

Occ - Umidade na capacidade de campo; $\theta p p$ - Umidade no ponto de murcha permanente

O preparo da área experimental consistiu em operação de aração e gradagem mecanizada. Cultivou-se um híbrido de repolho denominado 'Midore' no espaçamento de 0,5 x 0,4 $\mathrm{m}$. As mudas foram transplantadas quando apresentaram de 3 a 4 folhas definitivas, aos 21 dias após semeio.

Os tratamentos foram arranjados em delineamento de blocos ao acaso, em esquema fatorial $4 \times 2$, correspondendo a quatro níveis de adubação e dois níveis de cobertura do solo (ausência e presença de cobertura morta, com densidade de $9 \mathrm{t} \mathrm{ha}^{-1}$ ), com quatro repetições. Cada bloco possuía $18 \mathrm{~m}$ de comprimento e $15 \mathrm{~m}$ de largura. As quatro adubações foram: adubação organomineral (Takamix OM); adubação mineral (Uréia, Superfosfato simples e cloreto de potássio); adubação orgânica (20 t ha-1 de esterco de curral) e sem adubação (testemunha).

A adubação orgânica, organomineral e mineral foi realizada dois dias antes do transplante. A formulação para adubação com organomineral e mineral foi calculada com base na análise de solo para a camada de 0- 
0,2 m (Tabela 2), que corresponderam às quantidades de 159, 222,22 e 66,67 kg ha-1 de nitrogênio, fósforo e potássio, respectivamente e seguindo as necessidades da cultura, conforme as recomendações para a cultura do repolho no Estado de Pernambuco (CAVALCANTE, 2008).

Com relação à adubação orgânica (esterco de curral), abriram-se covas e adubou-se com uma quantidade de $400 \mathrm{~g}$ de esterco, correspondente a $20 \mathrm{t} \mathrm{ha}^{-1}$ para uma densidade de plantio de 50.000 plantas ha $^{-1}$. Utilizou-se também cobertura morta que foi adicionada 15 dias após transplante (DAT), utilizando capim elefante triturado, da variedade "Roxo de Botucatu", cobrindo toda área útil.

Tabela 2. Análise de fertilidade do solo na camada de $0-0,2 \mathrm{~m}$

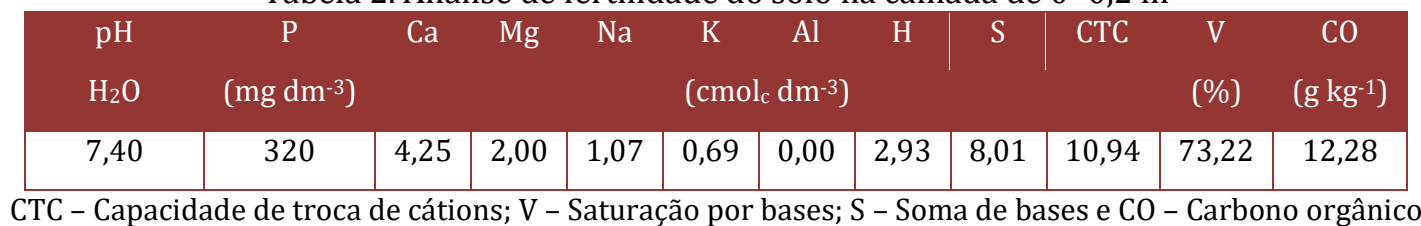

0 método de irrigação utilizado foi do tipo microaspersão, com $100 \%$ da área molhada, adotando um turno de irrigação diário. As lâminas de irrigação adotadas foram baseadas na evapotranspiração da cultura (ETc), estimada a partir de leituras diárias em Tanque Classe A, conduzidas pelo próprio agricultor, utilizando coeficiente de tanque de acordo com condições locais de vento, umidade relativa e bordadura, igual a 0,75, e coeficientes de cultura (Kc) segundo Doorenbos \& Kassan (1986).

O estudo conduziu-se na realização de duas amostragens de solo, aos 19 e 79 dias após transplante, nas profundidades de 0-0,20 e 0,20-0,40 m para avaliar o carbono orgânico total. 0 carbono orgânico total do solo (COT) foi quantificado de acordo com o método Walkley-Black (YEOMANS; BREMNER, 1988). Com os teores de carbono foi determinado o estoque de carbono nas profundidades avaliadas de acordo com a

$$
\text { Equação } 1 \text { (BERNOUX et al., 2002).ECOT }=\mathrm{D}_{\mathrm{S}} \times \mathrm{A} \times \mathrm{Q}
$$

em que:

ECOT - é o estoque de C do solo convertido em hectare $\left(\mathrm{Mg} \mathrm{ha}^{-1}\right)$; Ds - densidade do solo $\left(\mathrm{g} \mathrm{cm}^{-3}\right)$;

A - a espessura da camada amostrada (cm); Q - teor de C do solo (\%).

Os dados foram analisados no sistema computacional SAS (1998) e interpretados com base nas significâncias das análises de variância, pelo teste $\mathrm{F}$, sendo as médias comparadas pelo teste t a $5 \%$ de probabilidade.

\section{RESULTADOS E DISCUSSÃO}

De acordo com analise de variância para os parâmetros avaliados carbono orgânico total (COT) e estoque de carbono orgânico total no solo (ECOT) pode-se verificar que só houve efeito significativo para as profundidades avaliadas ao nível de probabilidade de $5 \%$ (Tabela 3). 
Tabela 3. Análise de variância para os dados de carbono orgânico total (COT) e estoque de carbono orgânico total do solo (ECOT) com nível de probabilidade 5\%.

\begin{tabular}{|c|c|c|c|c|}
\hline \multirow{3}{*}{ FV } & \multicolumn{4}{|c|}{$\operatorname{Pr}>\mathrm{F}$} \\
\hline & 19 DAT & & & \\
\hline & COT & ECOT & COT & ECOT \\
\hline A & $0,489^{\mathrm{NS}}$ & $0,4825^{\mathrm{NS}}$ & $0,4922^{\mathrm{NS}}$ & $0,5030^{\mathrm{NS}}$ \\
\hline $\mathrm{C}$ & $0,6783^{N S}$ & $0,6735^{\mathrm{NS}}$ & $0,4084^{N S}$ & $0,4410^{\mathrm{NS}}$ \\
\hline $\mathrm{P}$ & $<, 0001^{\mathrm{S}}$ & $<, 0001^{\mathrm{S}}$ & $0,0001^{S}$ & $0,0001^{S}$ \\
\hline$A \times C$ & $0,1514^{\mathrm{NS}}$ & $0,1458^{\mathrm{NS}}$ & $0,1347^{\mathrm{NS}}$ & $0,1299^{\mathrm{NS}}$ \\
\hline$A \times P$ & $0,9552^{\mathrm{NS}}$ & $0,9602^{\mathrm{NS}}$ & $0,6089^{N S}$ & $0,6036^{\mathrm{NS}}$ \\
\hline $\mathrm{C} \times \mathrm{P}$ & $0,5979^{\mathrm{NS}}$ & $0,5917^{\mathrm{NS}}$ & $0,9884^{N S}$ & $0,9807^{\mathrm{NS}}$ \\
\hline$A \times C \times P$ & $0,7536^{\mathrm{NS}}$ & $0,7715^{\mathrm{NS}}$ & $0,8810^{\mathrm{NS}}$ & $0,8835^{\mathrm{NS}}$ \\
\hline
\end{tabular}

NS - não significativo; S - significativo; A - adubação; C - cobertura; P - profundidade; FV - Fontes de variação

Na Figura 1A observa-se a diferença das médias para o carbono orgânico total do solo nas profundidades de 0-0,2 e 0,2-0,4 m aos 19 dias após transplante das mudas de repolho e três dias após a aplicação da cobertura morta de $9 \mathrm{t} \mathrm{ha}^{-1}$ de capim elefantetriturado.

Aos 19 DAT a média do COT foi de 11,1 e 8,8 $\mathrm{g} \mathrm{kg}^{-1}$ e aos 79 DAT esta média foi de 10,2 e 7,7 $\mathrm{g} \mathrm{kg}^{-1}$, para as profundidades de 0-0,2 e 0,2-0,4 m, respectivamente, ocorrendo uma redução de 20,72 e 24,50\% para os 19 e 79 DAT, respectivamente. Verificou-se um coeficiente de variação de 15,24\% e 21,99\% para os 19 e 79 DAT, respectivamente, indicando que houve uma média e alta variação dos dados.

Figura 1. Média dos teores de carbono orgânico total (A) e estoque de carbono orgânico total do solo (B) da área experimental.

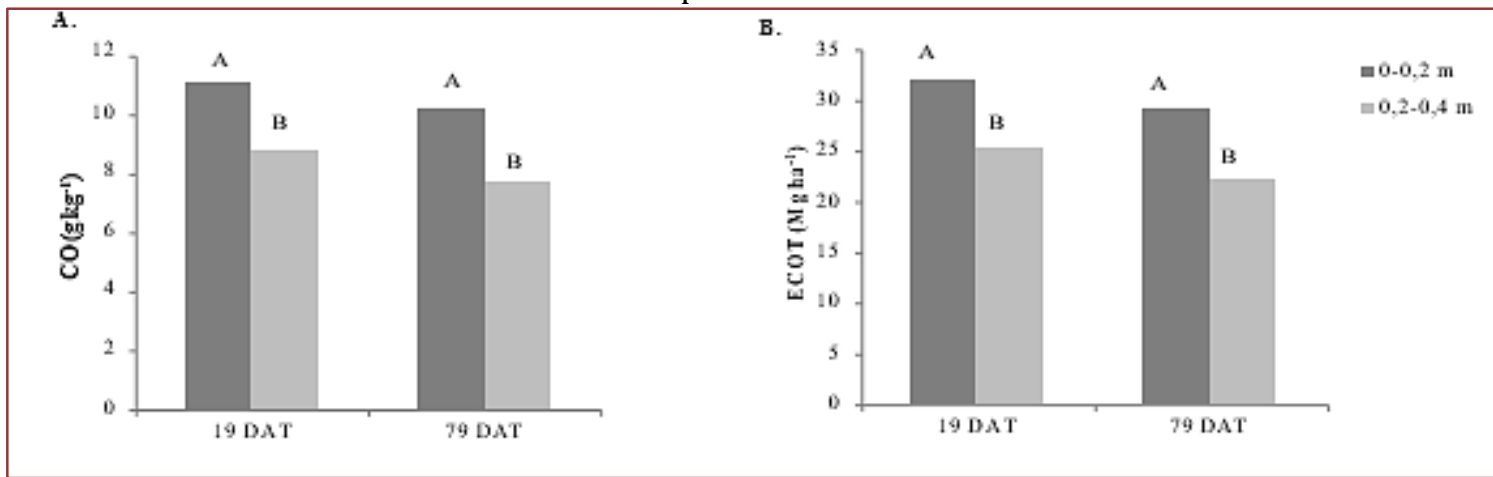

Letras maiúsculas diferentes diferem estatisticamente pelo teste $t(p<0,05)$ nas profundidades em cada período avaliado.

Para o estoque de carbono orgânico total nas profundidades avaliadas, a média foi de 32,08 e 25,38 $\mathrm{Mg} \mathrm{ha}^{-}$ 1 aos 19 DAT e 29,31 e 22,19 $\mathrm{Mg}$ ha $^{-1}$ aos 79 DAT para as profundidades de 0-0,2 e 0,2-0,4 m (Figura 1B). Houve uma redução no ECOT de 20,89 e 24,92\% aos 19 e 79 DAT.

Segundo Hickmann e Costa (2012), em um experimento conduzido por 23 anos sob sistema de plantio direto, verificaram-se uma redução no ECOT no perfil de 0 a $40 \mathrm{~cm}$ com variação de 9,23 a 5,59 $\mathrm{Mg} \mathrm{ha}^{-1}$, sendo estes valores baixos dos encontrados nesta pesquisa. De acordo com os teores de CO encontrados, podem ser classificados como médios para a amostragem realizada aos 19 e 79 DAT para a profundidade de 0-0,20 $\mathrm{m}$ e baixos teores para a profundidade de 0,2-0,4 $\mathrm{m}$.

Dantas et al. (2012), sob diferentes usos e manejos no Perímetro Irrigado Jaguaribe/Apodi - CE, também verificaram reduções nos teores de carbono orgânico total (COT) nos primeiros $5 \mathrm{~cm}$ de profundidade. 
Ainda esses mesmos autores verificaram que para a área com cultivo perene irrigado com banana, verificaram que entre $0-5 \mathrm{~cm}$ de profundidade houve redução de $19 \%$ do COT em relação à vegetação natural próxima à banana irrigada. Na área de cultivo irrigado com milho/soja esta redução chegou a $40 \%$ quando comparada com vegetação natural próxima ao milho irrigado.

De acordo com Fialho et al. (2006), o decrescimento do COT no solo esta relacionado com o aumento do quociente microbiano em áreas cultivadas. A redução do COT com o cultivo tem efeito negativo sobre a qualidade do solo, refletindo na ciclagem de nutrientes e atividade da biota (LEITE et al., 2010).

\section{CONCLUSÃO}

Houve uma redução na quantidade de carbono orgânico total (COT), como também no estoque de carbono orgânico total do solo (ECOT), nas diferentes profundidades 0-0,2 e 0,2-0,4 nos 19 DAT e 79 DAT

As diferentes adubações não proporcionaram diferença entre o carbono orgânico total e o estoque de carbono total do solo para o período de avaliação.

\section{REFERÊNCIAS}

[1] Bernuox, M.; Carvalho, M. C. S.; Volkoff, B.; Cerri, C. C. Brazil's soil carbon

[2] stocks. Soil Scienci Society of America Journal, v.66, p.888-896, 2002.

[3] Cavalcante, F. J. A. Recomendações de adubação para o Estado de Pernambuco: 2ª aproximação. 3. ed. rev. Recife: Instituto Agronômico de Pernambuco, 2008. 212 p.

[4] Doorenbos, J., Kassam, A. H. Yield response to water. Rome: FAO, Irrigation and Drainage Paper, 33. 1986.

[5] Dantas, A. N.; Oliveira, T. S.; Mendonça, E. S.; Assis, C. P. Qualidade de solo

[6] sob diferentes usos e manejos no Perímetro Irrigado Jaguaribe/Apodi, CE. Revista Brasileira de Engenharia Agrícola e Ambiental, v.16, p.18-26, 2012.

[7] Fialho, J. S.; Gomes, V. F. F.; Oliveira, T. S.; Silva Júnior, J. M. T. Indicadores da qualidade do solo em áreas sob vegetação natural e cultivo de bananeiras na Chapada do Apodi-CE. Revista Ciência Agronômica, v.37, p.250-257, 2006.

[8] Filgueira, F. A. R. Novo Manual de Olericultura: agrotecnologia moderna na produção e comercialização de hortaliças. Viçosa: UFV, 2008. 402p.

[9] Hickmann, C.; Costa, L. M. Estoque de carbono no solo e agregados em Argissolo sob diferentes manejos de longa duração. Revista Brasileira de Engenharia Agrícola e Ambiental, v.16, p.1055-1061, 2012.

[10] Leite, L. F. C.; Galvão, S. R. S.; Holanda Neto, M. R.; Araújo, F. S.; Iwata, B. F. Atributos químicos e estoques de carbono em Latossolo sob plantio direto no cerrado do Piauí. Revista Brasileira de Engenharia Agrícola e Ambiental, v.14, p. 1273-1280, 2010.

[11] Lal, R. Sequestration of atmospheric $\mathrm{CO} 2$ in global carbon pools. Energy Environmental Science, v.1, p.86$100,2008$.

[12] Montenegro, A. A. A.; Montenegro, S. M. G. L. Variabilidade espacial de classes de textura, salinidade e condutividade hidráulica de solos em planície aluvial. Revista Brasileira de Engenharia Agrícola e Ambiental, v.10, p.30-37, 2006.

[13] Resck, D. V. S.; Ferreira, E. A. B.; Figueiredo, C. C.; Zinn, Y. L. Dinâmica da

[14] matéria orgânica no Cerrado. In: Santos, G. A.; Silva, L. S.; Canellas, L. P.; Camargo, F. A. O., eds. Fundamentos da matéria orgânica do solo: Ecossistemas tropicais e subtropicais. 2.ed. Porto Alegre, Metrópole, 2008. p.359-417.

[15] Rumpel, C.; Kögel-Knabner, I. Deep soil organic matter - A key but poorly understood component of terrestrial C cycle. Plant Soil, 338:143-158, 2011.

[16] Yeomans, J. C.; Bremner, J. M. A rapid and precise method for routine determination of organic carbon in soil. Communications in Soil Science and Plant Analysis, v.19, p.1467- 1476, 1988. 


\section{Capítulo 8}

\section{Estudo do manejo de irrigação via solo e via clima na cultura do milho}

\section{Ana Rita Costenaro Parizi \\ Gideon Ujacov Silva \\ Otávio Pivoto \\ Monique Denis Cabral \\ Chaiane Guerra da Conceição \\ Ana Carla dos Santos Gomes}

Resumo: 0 objetivo do estudo foi avaliar o efeito do manejo da irrigação via solo e via clima sob a cultura do milho conduzida na região de Alegrete, RS. 0 experimento foi constituído de um delineamento inteiramente casualizado com três tratamentos (manejos de irrigação): via solo (T1), via clima (T2) e precipitação pluviométrica (T0) e 3 repetições, sendo repetido durante três safras consecutivas. A semeadura da cultura do milho foi realizada no mês de outubro, sendo irrigado por aspersão. Ao final do ciclo foram avaliados os componentes de produção de grãos. A lâmina total aplicada de água durante o ciclo da cultura, na última safra estudada ficou dentro da necessidade da cultura, já nas duas primeiras safras o volume total foi superior á necessidade da cultura. Concluiu-se que os três anos de estudo, foram anos chuvosos na época de cultivo, com exceção do último ano, por esta razão os resultados com o uso da irrigação não foram expressivos, refletindo nos parâmetros avaliados. No entanto, ocorreram períodos de necessidade hídrica, exigindo irrigações suplementares, tornando o manejo de irrigação via solo mais eficiente por utilizar volume menor de água, sendo este recomendado, em razão do menor número de irrigações.

Palavras-Chave: tensiômetro, tanque classe A, produtividade 


\section{INTRODUÇÃO}

A cultura do milho necessita de uma quantidade de água estimada entre 500 e $600 \mathrm{~mm}$, e o consumo diário varia dependendo da temperatura e estágio de desenvolvimento da planta (CRUZ et al., 2010). Observam-se altas taxas de variações no rendimento da cultura, decorrente de instabilidades no regime de chuvas, período conhecido como déficit hídrico. No estado do Rio Grande do Sul, períodos de instabilidade são recorrentes, o volume precipitado, seria suficiente para atender a demanda hídrica da cultura, porém ocorrem longos períodos de estiagem, o que justifica a prática da irrigação suplementar. Para Mourelli et al. (2017), por manejo de água de irrigação, entende-se em determinar o momento adequado para irrigar as plantas e a lâmina de água a ser reposta ao solo em cada irrigação. A resposta para tais perguntas é dependente de vários fatores, como do tipo de solo, das condições climáticas, da espécie cultivada e da fase de desenvolvimento da cultura. 0 momento ideal para a irrigação deve ser aquele quando as plantas tenham utilizado toda a água toda a água facilmente disponível. A quantidade de água a ser aplicada deve ser equivalente àquela evapotranspirada desde a última irrigação, descontando-se possíveis chuvas significativas, e ser suficiente para que o solo retorne à sua condição de capacidade de campo.

Desta forma, o objetivo deste trabalho foi avaliar o efeito do manejo da irrigação via solo e via clima sob a cultura do milho em três safras consecutivas na região fronteira oeste do Rio Grande do Sul.

\section{MATERIAL E MÉTODOS}

O trabalho foi desenvolvido em área experimental do Instituto Federal Farroupilha - Campus de Alegrete/RS.. O solo da área experimental utilizado para a pesquisa é classificado como Argissolo Vermelho Distrófico arênico (EMBRAPA, 2005). O clima da região é classificado como Cfa subtropical úmido sem estação seca e com temperaturas variando de $14,3^{\circ} \mathrm{C}$ no inverno a $26,3^{\circ} \mathrm{C}$ no verão, com média de precipitações anuais de $1400 \mathrm{~mm}$ (MORENO, 1961).

0 experimento foi constituído de um delineamento experimental inteiramente casualizado com 3 tratamentos (manejos de irrigação): Precipitação (T0), Via clima (T1) e Via solo (T2) (figura 1) com três repetições cada tratamento. Cada repetição foi constituída, de uma área de $8 \times 24 \mathrm{~m}$, totalizando $576 \mathrm{~m}^{2} /$ tratamento, os quais foram configurados conforme a disposição do sistema de irrigação do tipo aspersão convencional utilizado. Na aplicação do T1 as irrigações foram aplicadas com base nas leituras diárias de evaporação do Tanque Classe A. Para a obtenção das lâminas de irrigação foi aplicada a seguinte fórmula: $\mathrm{ETc}=\mathrm{EV} \times \mathrm{Kp} \times \mathrm{Kc}$, Em que: ETc é evapotranspiração de referência (mm), EV é a evaporação do Tanque Classe A (mm), Kp é coeficiente do tanque classe A e Kc é coeficiente de cultura. Os valores de Kp e Kc, foram obtidos de acordo com Büchele e Silva (1992). A lâmina de irrigação foi reposta em turno de rega fixo a cada 4 dias, onde foi realizado o somatório da ETc do período e subtraído em caso de precipitação pluviométrica.Na aplicação do T2 foi utilizada a equação: $L i=(U c c-M I) \times p) / E a$, onde: $L i$ é a lâmina de irrigação (mm), Ucc é a umidade correspondente a capacidade de campo, $M I$ é a umidade correspondente a tensão crítica $\left(\mathrm{cm}^{3} / \mathrm{cm}^{3}\right), p$ é profundidade efetiva do sistema radicular $(\mathrm{mm})$ e $E a$ é a eficiência de aplicação do sistema, conforme Bernardo (1989). Para determinação de Ucc foi realizada a calibração de tensiômetros do tipo vacuômetro metálico tipo Bourdon e para a obtenção da $M I$, foi realizado um cálculo utilizando a função gerada pelo gráfico da curva de retenção, sendo que esse valor foi calculado quando a tensão dos tensiometros estivam próxima a $400 \mathrm{mmhg}$. A determinação do $p$ foi realizada quinzenalmente, onde foram abertas três pequenas trincheiras ao lado da planta, de maneira que possibilitou verificar a profundidade que se encontram cerca de $80 \%$ das raízes efetivas (VIEIRA, 1996).A produtividade da cultura foi avaliada no final do ciclo, quando foram coletadas as espigas de milho em 15 metros lineares dentro de cada tratamento, sendo três repetições de 5 metros lineares, coletadas em lugares distintos dentro da mesma parcela. Foram determinados os seguintes componentes de produção: número de espigas por planta, número de grãos por espiga e peso de mil dos grãos. Para interpretação dos resultados foi realizada a análise da variância. Caso houver significância, as médias serão comparadas entre si pelo Teste de Tukey ao nível de 5\% de probabilidade de erro. Foi utilizado o programa computacional Assistat 7.7 Beta.

\section{RESULTADOS E DISCUSSÃO}

Durante a condução dos experimentos ocorreram as seguintes precipitações: ano 2014/2015: 829,60mm de chuva; 89,25 mm de irrigação (T1); 29,20mm de irrigação (T2); ano 2015/2016: 952,60mm de chuva; 97,52 mm de irrigação (T1); 54,62mm de irrigação (T2); ano 2016/2017: 495,16mm, 91,35 mm de irrigação (T1); 31,58mm de irrigação (T2). 
A Tabela 01 apresenta os valores relativos aos componentes de rendimento obtidos ao final do ciclo da cultura do milho durante os três anos de experimento.

Tabela 01: Valores médios de número de espigas.planta-1 (NEP), número de grãos.espiga-1 (NGE), peso médio do grão (PMG) e produção de grãos em sc.ha-1.

\begin{tabular}{|c|c|c|c|c|}
\hline Tratamento & NEP & NGE & PMG (g) & $\begin{array}{l}\text { Produtividade } \\
\text { (sc.ha-1) }\end{array}$ \\
\hline \multicolumn{5}{|c|}{ Safra 2014/2015 } \\
\hline T0 & $1,00 \mathrm{a}$ & $621,20 a$ & $0,332 \mathrm{a}$ & $208,96 b$ \\
\hline T1 (via clima) & $1,00 \mathrm{a}$ & $679,90 \mathrm{a}$ & $0,323 a$ & $214,13 b$ \\
\hline T2 (via solo) & $1,00 \mathrm{a}$ & $694,38 a$ & $0,315 a$ & $257,48 a$ \\
\hline Média & 1 & 665,16 & 0,32 & 226,86 \\
\hline CV (\%) & 0 & 9,1 & 8,8 & 6,19 \\
\hline \multicolumn{5}{|c|}{ Safra $2015 / 2016$} \\
\hline T0 & $1,00 a$ & $472,91 a$ & $0,30 \mathrm{a}$ & $147,15 a$ \\
\hline T1 (via clima) & $1,00 \mathrm{a}$ & $528,00 \mathrm{a}$ & $0,31 a$ & $205,01 a$ \\
\hline T2 (via solo) & $1,00 \mathrm{a}$ & $500,19 a$ & $0,30 a$ & $177,25 a$ \\
\hline Média & 1 & 500,37 & 0,31 & 190,97 \\
\hline CV (\%) & 0 & 29,32 & 8,65 & 35,83 \\
\hline \multicolumn{5}{|c|}{ Safra $2016 / 2017$} \\
\hline T0 & $1,00 \mathrm{a}$ & $427,10 a$ & $0,28 \mathrm{a}$ & $251,77 a$ \\
\hline T1 (via clima) & $1,00 \mathrm{a}$ & $433,43 a$ & $0,25 a$ & $286,86 a$ \\
\hline T2 (via solo) & $1,00 a$ & $452,17 a$ & $0,27 \mathrm{a}$ & \\
\hline Média & 1 & 437,57 & 0,27 & 264,59 \\
\hline CV (\%) & 0 & 25,42 & 6,03 & 8,42 \\
\hline
\end{tabular}

Na tabela pode-se observar que não ocorreram diferenças estatísticas nas variáveis que foram analisadas, com exceção do primeiro ano para a variável produção de grãos, em que o T2 se deferiu T0 e do T1, produzindo 257,48 sc.ha-1. No primeiro ano o NEP não apresentou diferenças, já o NGE e a produção de grãos foram maior no T2, obtendo 694,38 grãos e 257,48 sc.ha-1 respectivamente e o PMG apresentou o maior peso no T0, com 0,332g. No ano 2 o NEP também não apresentou resultados diferentes, já o NGE, PMG e a produção de grãos apresentaram melhores resultados no T1, apresentando resultados de 528 grãos, 0,3186 g e 205,011 sc.ha-1 respectivamente. Já no último ano o NEP também não apresentou resultados diferenciados, porém o NGE apresentou o maior numero de grãos no T2, com 452,17 grãos, já o PMG teve o maior peso no T0, com $0,281 \mathrm{~g}$, e por último a produção de grãos teve o melhor resultado no T1, com 286,861 sc.ha-1.

Soares et al. (2012), trabalhando com a viabilidade da irrigação de precisão na cultura do milho com o cultivar BM 1120, encontrou resultados semelhantes, sendo que o NEP foi exatamente igual, já o NGE a autora obteve um valor médio de 415,80 grãos.espiga- ${ }^{-1}$, e no PMG o valor encontrado foi de 0,31g. A produtividade média de 230,2 sc.ha $^{-1}$ de grãos, sendo que, em algumas seções do pivô central os resultados semelhantes ao presente trabalho.

Já Parizi (2007) avaliando o efeito de diferentes estratégias de irrigação na cultura do milho verificou que o maior número de grãos.espiga ${ }^{-1}$ foi obtido no tratamento com suplementação de $100 \%$ da ETc $(64,0$ $\mathrm{mm}$ ) com uma média de 411,52 grãos.espiga-1 e o menor número foi no tratamento sem irrigação com média de 340,60 grãos.espiga-1.

\section{CONCLUSÕES:}

Apesar dos volumes de chuva terem sido elevados ocorreram períodos de necessidade hídrica, exigindo irrigações suplementares, tornando o manejo de irrigação via solo mais eficiente por utilizar volume menor de água, sendo este recomendado, em razão do menor número de irrigações. 


\section{REFERÊNCIAS:}

[1] Bernardo, S. Manual de irrigação. 8. Ed. Viçosa: UFV, imprensa Universitária, 2006.51-68p.

[2] Cruz, J. C.; Filho, I. A. P.; Alvarenga, R. C.; Neto, M. M. G.; Viana, J. H. M. V.; Oliveira, M. F.; Matrangolo, W. J. R.; Filho, M. R. A. Cultivo do Milho. Embrapa Milho e Sorgo Sistemas de Produção, 2. ISSN 1679-012X Versão Eletrônica - 6 a edição Set./2010.

[3] Empresa Brasileira de Pesquisa Agropecuária - Embrapa. Centro Nacional de Pesquisa de Solos. Sistema brasileiro de classificação de solos. Brasília, 1999. 412p.

[4] Marouelli, W. A., Silva, H. R., Silva, W. L. C... Irrigação por aspersão em hortaliças : qualidade da água, aspectos do sistema e método prático de manejo. 4 ed. Brasília, DF : Embrapa, 2017. 200 p. :

[5] Moreno, J. A. 1961. Clima do Rio Grande do Sul. Secretária da Agricultura, Porto Alegre, Brasil, 42pp.Vieira, D.B.; Genovez, A.M.; Gomes, E.M. Determinação da profundidade efetiva do sistema radicular do milho (Zea mays L.) irrigado. In: Congresso Nacional de Irrigação e Drenagem, 11., 1996, Campinas. Anais. Campinas: ABID, 1996. p.95106.

[6] Parizi, A. R. C. Efeito de diferentes estratégias de irrigação sob as culturas de feijão (Phaseolus vulgaris l.) e milho (Zea mays l.) na região de Santiago, RS. 2007. 124 f. Dissertação (Mestrado em Engenharia Rural) - Universidade Federal de Santa Maria, Santa Maria, 2007.

[7] Soares, F. C.; Peiter, M. X.; Robaina, A. D.; Parizi, A. R. C.; Vivan, G. A. Resposta da cultura do milho à variabilidade hídrica em solo Sob pivô central. Revista Irriga, Botucatu, v. 17, n. 2, p. 220 - 233, abril-junho, 2012.

[8] Vieira, D.B.; Genovez, A.M.; Gomes, E.M. Determinação da profundidade efetiva do sistema radicular do milho (Zea mays L.) irrigado. In: Congresso Nacional de Irrigação e Drenagem, 11., 1996, Campinas. Anais. Campinas: ABID, 1996. p.95-106. 


\section{Capítulo 9}

\section{Atributos físicos de um latossolo vermelho-amarelo submetido a diferentes sistemas de manejo}

\section{Luiz Fernando Costa Ribeiro Silva \\ Letícia Almeida \\ Alberto Carvalho Filho}

Resumo: É preconizado que a boa qualidade física do solo é fundamental para um adequado desenvolvimento das plantas e obtenção de maior produtividade das culturas. 0 adensamento e a compactação do solo estão entre os principais problemas associados à menor produtividade das culturas e à degradação de solos agrícolas. Objetivou-se com este trabalho avaliar o efeito dos equipamentos de preparo convencional do solo na resistência mecânica do solo à penetração (RMSP), umidade do solo, densidade do solo e seus efeitos na produtividade da cultura do feijão. 0 experimento foi implantado na Universidade Federal de Viçosa, Campus Rio Paranaíba. 0 solo do local é classificado como LATOSSOLO VERMELHO-AMRELO Distrófico, com $42 \%$ de argila. Os tratamentos de preparo convencional de solo foram: arado de discos; grade aradora intermediária; escarificador; enxada rotativa. Não foi observada diferença entre os equipamentos de preparo de solo para a RMSP e umidade do solo. No entanto, na camada de 0,0-0,1 m, de todos os tratamentos, por ter sofrido mobilização, apresentou menor valor de resistência se comparada à camada subsuperficial. Não houve diferença significativa na densidade do solo para os tratamentos de preparo de solo em nenhuma camada de solo avaliada, no entanto, ao longo do perfil do solo foram verificados valores distintos de densidade do solo. 0 preparo de solo efetuado por distintos equipamentos não influenciou a produtividade do feijão, a população final de plantas, o número de vagens por planta e o número de grãos por vagem.

Palavras-chave: Penetrômetro de impacto; Phaseolus vulgaris L.; Trado de Uhland 


\section{INTRODUÇÃO}

É preconizado que a boa qualidade física do solo é fundamental para um adequado desenvolvimento das plantas e obtenção de maior de produtividade das culturas. Ao se tratar de compactação do solo, é importante salientar que este é um dos principais problemas associados à menor produtividade das culturas e degradação de solos agrícolas. Isso está relacionado à diminuição dos espaços porosos do solo, acarretando no aumento de sua resistência à penetração, aumento da densidade do solo, redução da infiltração de água e diminuindo a capacidade de penetração das raízes e também a capacidade destas absorverem água e nutrientes com eficiência. Com base nisto, é necessário que o manejo e preparo do solo devem contribuir para melhoria e/ou manutenção de suas qualidades. Porém sabe-se que este preparo, muitas vezes, é feito sem embasamento científico, o que pode gerar problemas para a estrutura do solo ao longo do tempo (Silva, 2015).

As plantas apresentam certo grau de tolerância à compactação do solo, mas a partir de valores críticos elas respondem negativamente ao efeito o que compromete seu desenvolvimento (Silva et al., 2000). Deve-se a isto o fato das raízes novas terem seu desenvolvimento prejudicado em solos compactados e assim não absorverem adequadamente água e nutrientes (Queiroz-voltan et al., 2000).

Estudos como o de Collares et al. (2008), demonstram que a produtividade da cultura do feijão em sistema de plantio direto (SPD) com compactação adicional reduziu em 17\% quando comparado ao SPD sem compactação. Já de acordo com Valadão et al. (2017), a compactação proporcionou redução da produtividade de soja e redução da eficiência da adubação fosfatada. Dados que corroboram com o apresentado por Freddi et al. (2009), onde avaliaram as respostas de duas cultivares de milho com características genéticas distintas em um Latossolo Vermelho em seis diferentes valores de compactação, e verificaram que a produtividade dos dois híbridos foi significativamente menor quando o valor de resistência à penetração atingiu a 2,15 MPa, na tensão de água do solo de $100 \mathrm{hPa}$.

Plantas em solos compactados apresentam o sistema radicular mais superficial (Müller et al., 2001). Isso pode proporcionar menor eficiência da planta em absorver nutrientes que são mais propensos à lixiviação, além de serem mais frágeis a estresses hídricos, predispostas ao tombamento, ataque de pragas e doenças e, por fim, diminuição da produtividade. Segundo Marschner (1995), em solo compactado seco, ocorre maior resistência física ao crescimento das raízes e o potencial de água é menor, e, em solo úmido, há falta de oxigênio, elevadas concentrações de etileno na zona radicular, proveniente da menor aeração. Além disso, em solo compactado úmido pode ocorrer maior taxa de perda de nitrogênio por desnitrificação.

O manejo do solo influencia diretamente na ocorrência de compactação. No preparo convencional do solo ocorre o revolvimento de camadas superficiais para reduzir a compactação, incorporação de corretivos e fertilizantes, aumento dos espaços porosos e, assim, elevar a permeabilidade e o armazenamento de ar e água (Santiago \& Rossetto, 2007).

Existem diversos equipamentos para realizar o preparo convencional do solo, e, de acordo com Sá (1998), cada equipamento apresenta um próprio sistema de trabalho no solo, alterando de maneira distinta suas propriedades químicas, físicas e biológicas. 0 arado de discos é uma máquina que pode ser utilizado para o preparo periódico primário do solo. Este equipamento trabalha melhor em condições mais adversas, a leiva é invertida em inclinações menores, proporciona um efeito de esboroamento do solo maior, os resíduos vegetais são incorporados a uma menor profundidade e são bastante misturados ao solo, se comparado ao arado de aivecas (Falleiro et al., 2003).

A influência do manejo e a sua magnitude nas propriedades físicas do solo não somente depende da classe textural do solo, mas, também, das condições climáticas, sistemas de cultura utilizados, tempo de uso dos diferentes sistemas de manejo e umidade do solo que são realizadas as operações de campo (Costa et al., 2003). Por isso há diversos estudos relacionados ao sistema de manejo e propriedades físicas do solo.

Para visualizar a compactação do solo podem-se utilizar diversos meios de análises, como aberturas de trincheiras para observação do perfil do solo, aspectos visuais da superfície do solo (marcas do rodado de equipamentos agrícolas, propensão do solo à erosão, etc), crescimento e desenvolvimento das plantas, desenvolvimento das raízes, entre outros. Por outro lado, diversos trabalhos apontam que a densidade do solo e a resistência mecânica do solo à penetração (RMSP) são os parâmetros mais utilizados (Carvalho Filho et al., 2007).

A densidade do solo e a resistência à penetração são diretamente influenciadas pelo preparo convencional do solo. Assim, Aratani et al. (2009) afirmam que o preparo convencional favorece o aumento da densidade do solo e RMSP em subsuperfície. Isso pode ser explicado pelo fato dos órgãos ativos dos equipamentos utilizados no preparo convencional do solo causar uma camada compactada, chamada "pé 
de arado", "pé de grade", ou "soleira", logo abaixo à camada mobilizada. Essa camada subsuperficial compactada está entre as principais causas de degradação da estrutura do solo (Campos et al., 1995), e essa degradação está associada à redução do desenvolvimento vegetal e predisposição do solo à erosão hídrica (Stone et al., 2001).

A RMSP é utilizada para expressar o impedimento do solo à penetração radicular. Para Canarache (1990), o valor de RMSP de 2,5 MPa é considerado crítico para o crescimento radicular. Tormena et al. (1998) apontam que o valor crítico é de 2,0 MPa. Porém para Beutler \& Centurion (2004), que avaliaram o efeito da compactação no desenvolvimento radicular e produtividade da soja, perceberam que a produtividade de grãos de soja sofreu decréscimo a partir do valor de RMSP de 0,85 MPa. De acordo Silva et al. (2004) os valores de RMSP entre 3,5 e 6,5 MPa são apontados como mais corretos para considerar o solo com impedimento à penetração. Esses valores diferem muito na literatura, pois é necessário avaliar outros fatores, como a umidade do solo em que a RMSP foi avaliada, devido esta apresentar relação inversa com a resistência à penetração; a textura, estrutura e mineralogia do solo avaliado, por exemplo, considerando se a mesma ordem de solos, os mais argilosos tendem a apresentar maior valor de RMSP quando comparados aos mais arenosos, para uma mesma umidade; entre outros.

A densidade do solo identifica as camadas compactadas e é diretamente utilizada para a avaliação da intensidade de compactação. Bertol et al. (2004) observaram menor valor de densidade do solo no preparo convencional em relação a semeadura direta, considerando que a média da profundidade do solo estudada foi até 0,3 m. Collares et al. (2006), em um Argissolo, apontaram que o valor de densidade de 1,75 g cm-3 (baseada no índice hídrico ótimo - IHO) é crítico para menor produtividade na cultura do feijoeiro. Para Freddi et al. (2009) o valor crítico na camada de 0,0 a 0,3 m foi de 1,46 g cm-3 para a cultura do milho implantada num Latossolo Vermelho. Bowen (1981) considera crítico os valores de 1,55 g cm-3 e 1,85 g cm-3 para solos argilosos e arenosos, respectivamente, a partir desses valores há restrição do desenvolvimento radicular. Entretanto, não existe na literatura um valor definido com crítico de densidade para cada classe do solo, então é preciso cuidado ao considerar um valor absoluto como referência para concluir se um solo está ou não compactado.

O problema de compactação do solo impõe certa importância no planejamento agrícola, visto que, além de perdas significantes de produtividade por parte das culturas instaladas em solos com esse problema, o custo para a reversão do processo de compactação é alto. Sabendo disso, Carvalho Filho et al. (2007), afirmam que esse processo de reversão exige equipamentos específicos, máquinas de potências altas, o que resulta em um aumento no custo de produção por unidade de área. Então, o objetivo deste trabalho foi avaliar o efeito dos equipamentos de preparo convencional do solo em alguns atributos físicos e na produtividade da cultura do feijão (Phaseolus vulgaris L.).

\section{MATERIAL E MÉTODOS}

\subsection{CARACTERIZAÇÃO DA ÁREA}

O trabalho foi realizado durante a safra de 2018/2019 na área experimental da Universidade Federal de Viçosa, Campus Rio Paranaíba, no município de Rio Paranaíba (MG), que possui média de $1.100 \mathrm{~m}$ de altitude. 0 solo do local é classificado como LATOSSOLO VERMELHO-AMRELO Distrófico, com $42 \%$ de argila, o relevo é considerado plano e a área é manejada com os mesmos sistemas de preparo de solo desde o ano 2014 para a produção de grãos.

O delineamento utilizado foi inteiramente casualizado (DIC), com quatro tratamentos e quatro repetições, totalizando 16 unidades experimentais. Os tratamentos de preparo convencional de solo foram: arado de discos; grade aradora intermediária; escarificador; enxada rotativa. As unidades experimentais apresentavam área de $100 \mathrm{~m} 2$, sendo estas espaçadas por carreadores, também com área de $100 \mathrm{~m} 2$, destinados a manobras e regulagens dos equipamentos.

\subsection{PREPARO DO SOLO}

Para realizar o preparo de solo foi utilizado o trator New Holand TL85E, com a rotação de 2000 rpm, marcha terceira reduzida e velocidade média de trabalho de 5,0 km h-1. Os tratamentos foram: T1 - Arado de discos, marca BALDAN $\AA$, modelo AF-3, com três discos côncavos lisos, trabalhando a uma profundidade média de 0,3 m; T2 - Grade aradora intermediária, marca KÖHLER®, modelo GAC300, equipada com 14 discos e com profundidade média de ação de 0,2 m; T3 - Escarificador, marca JAN, modelo Jumbo Matic Hidráulico, equipado com discos de corte, cinco hastes parabólicas e ponteiras sem 
asa, a largura de trabalho foi dois metros e a profundidade média de ação do equipamento 0,2 m; T4 Enxada rotativa, marca MEC-RUL®, modelo ERP200B, equipada com oito flanges e 48 lâminas, trabalhando a uma profundidade média de $0,1 \mathrm{~m}$. Todos os equipamentos utilizados foram fornecidos pela Universidade Federal de Viçosa, Campus Rio Paranaíba.

Com exceção do T4, após o preparo primário do solo foi feita duas passadas de uma grade destorroadoraniveladora para realizar o preparo secundário do solo. As operações de preparo de solo foram feitas utilizando o mesmo trator, sendo elas realizadas um mês antecedendo a semeadura da cultura do feijão. A umidade do solo no dia do preparo foi de $35 \%$ e a semeadura do feijão foi realizada no dia oito de janeiro de 2019 pelo produtor arrendatário do local. A cultura instalada foi do feijão BRS estilo, que apresenta ciclo médio de 100 dias e para a semeadura utilizou-se o trator Massey Ferguson 4292, 1600 rpm, terceira marcha reduzida, trabalhando em uma velocidade média de 5,0 km h-1. Devido ao intervalo de tempo entre o preparo do solo e o plantio, efetuou-se o controle de plantas daninhas com a passagem de uma grade aradora seguida de uma niveladora, manejo adotado pelo produtor que arrendou a área. Após 80 dias do preparo convencional do solo foram realizadas as avaliações de densidade do solo, resistência mecânica do solo à penetração e umidade do solo.

\subsection{ATRIBUTOS FÍSICOS E AGRONÔMICOS}

A densidade do solo foi determinada utilizando o método de amostra indeformada de solo do anel volumétrico (Embrapa, 1997). Portanto, a coleta foi realizada com o trado tipo Uhland, utilizando anéis com volume conhecido, da camada de 0,0 - 0,1 $\mathrm{m}$ até a profundidade de 0,5 - 0,6 $\mathrm{m}$, realizando a coleta a cada $0,1 \mathrm{~m}$. Foram coletados três pontos distintos em cada parcela e a média dos valores correspondentes a cada camada foi utilizada como representativa para a unidade experimental.

As amostras indeformadas de solo coletadas foram identificadas e levadas para secagem utilizando o método da estufa pelo período de 24 horas a uma temperatura de $105^{\circ} \mathrm{C}$ a 110 으. Após 24 horas as amostras secas foram pesadas, utilizando uma balança com 0,01 g de precisão, e foi retirado o peso do anel volumétrico para a obtenção da massa de solo seca e, em seguida, foi determinada a densidade daquela amostra de solo.

Para avaliar a RMSP, utilizou-se o penetrômetro de impacto modelo IAA/Planalsucar-Stolf. Foram avaliados três pontos aleatórios dentro de cada unidade experimental, sendo a avaliação feita ao longo do perfil do solo da camada de 0,0 - 0,1 $\mathrm{m}$ até a camada 0,5 - 0,6 m e os impactos registrados a cada 0,1 m. 0 valor médio de cada camada foi utilizado como representativo para a unidade experimental. Os valores obtidos na avaliação são registrados em impactos dm-1, que posteriormente foram transformados em unidade de pressão (MPa) de acordo com o proposto por Stolf (1990).

A determinação da umidade do solo foi feita utilizando as mesmas amostras indeformadas coletadas para avaliação da densidade do solo. Sendo assim, as amostras foram coletadas, identificadas e pesadas para a obtenção da massa úmida. Em seguida as amostras foram secas e pesadas novamente para a obtenção da massa seca.

A colheita do feijão foi realizada de forma manual, sendo, também, determinada a população final, número de vagens por planta, número de grãos por vagem e produtividade em grãos. A umidade dos grãos foi ajustada para $13 \%$ para determinar a produtividade.

\subsection{ANÁLISES ESTATÍSTICAS}

Os dados foram tabulados e submetidos à análise de variância, sendo que foi verificado o atendimento aos pressupostos como a homocedasticidade e a normalidade dos resíduos. Quando significativo, a diferença entre as médias foi avaliada através do teste Tukey, ao nível de $5 \%$ de probabilidade. Para a realização das análises estatísticas foi utilizado o programa SPEED Stat (Carvalho \& Mendes, 2017).

\section{RESULTADOS E DISCUSSÃO}

Os resultados obtidos na Tabela 1 demonstram que não houve diferença estatística entre os equipamentos de preparo de solo para a RMSP e umidade do solo nas camadas avaliadas ao longo do perfil do solo. Mas a camada de 0,0 - 0,1 m, de todos os tratamentos, por ter sofrido mobilização e devido ao maior volume de raízes, observado visualmente, apresentou menor valor de resistência se comparada à camada 
subsuperficial. Este resultado corrobora com o encontrado por Carvalho Filho et al. (2007), Ortigara et al. (2014), Silva (2015), Valente et al. (2019).

Tabela 1. Desdobramento da relação dos sistemas de preparo de solo e profundidade para a resistência mecânica do solo à penetração (RMSP) e umidade do solo

\begin{tabular}{|c|c|c|c|c|c|}
\hline \multirow[b]{2}{*}{ Profundidade (m) } & \multicolumn{5}{|c|}{ Sistemas de preparo } \\
\hline & $\mathrm{AD}$ & GA & ES & ER & CV (\%) \\
\hline \multicolumn{6}{|c|}{ 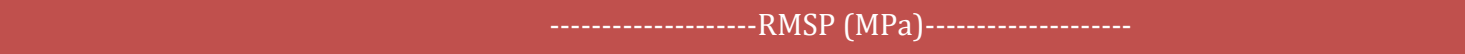 } \\
\hline $0,0-0,1$ & $0,72 \mathrm{cA}$ & $0,83 \mathrm{cA}$ & $0,70 \mathrm{bA}$ & $0,83 \mathrm{bA}$ & 35,81 \\
\hline $0,1-0,2$ & $2,24 \mathrm{abA}$ & $2,07 \mathrm{abA}$ & $2,24 \mathrm{aA}$ & $2,63 \mathrm{aA}$ & 21,15 \\
\hline $0,2-0,3$ & $2,63 \mathrm{aA}$ & $2,47 \mathrm{aA}$ & $2,46 \mathrm{aA}$ & 2,86 aA & 13,58 \\
\hline $0,3-0,4$ & $2,01 \mathrm{bA}$ & $2,41 \mathrm{aA}$ & $2,41 \mathrm{aA}$ & $2,69 \mathrm{aA}$ & 19,23 \\
\hline $0,4-0,5$ & $1,96 \mathrm{bA}$ & $1,96 \mathrm{abA}$ & $1,84 \mathrm{abA}$ & 2,13 aA & 14,90 \\
\hline $0,5-0,6$ & $1,73 \mathrm{bA}$ & $1,73 \mathrm{bA}$ & $1,73 \mathrm{abA}$ & $2,01 \mathrm{aA}$ & 17,52 \\
\hline CV (\%) & 13,59 & 12,06 & 24,29 & 21,43 & \\
\hline \multicolumn{6}{|l|}{$\mathrm{m}$} \\
\hline $0,0-0,1$ & $31,72 \mathrm{aA}$ & 32,82 aA & $34,22 \mathrm{aA}$ & $30,91 \mathrm{aA}$ & 10,8 \\
\hline $0,1-0,2$ & $31,69 \mathrm{aA}$ & $31,11 \mathrm{aA}$ & $30,88 \mathrm{bcA}$ & $30,96 \mathrm{aA}$ & 7,91 \\
\hline $0,2-0,3$ & 31,33 aA & 31,48 aA & $30,69 \mathrm{cA}$ & $30,76 \mathrm{aA}$ & 8,39 \\
\hline $0,3-0,4$ & $31,77 \mathrm{aA}$ & 31,42 aA & 31,68 abcA & $31,84 \mathrm{aA}$ & 8,09 \\
\hline $0,4-0,5$ & $33,22 \mathrm{aA}$ & 33,62 aA & $32,60 \mathrm{abcA}$ & $33,02 \mathrm{aA}$ & 5,67 \\
\hline $0,5-0,6$ & $34,65 \mathrm{aA}$ & 34,02 aA & $33,75 \mathrm{abA}$ & $33,80 \mathrm{aA}$ & 5,21 \\
\hline CV (\%) & 8,34 & 7,72 & 4,11 & 9,73 & \\
\hline
\end{tabular}

Médias seguidas por mesma letra minúscula na coluna e maiúscula na linha não diferem entre si pelo teste Tukey a 5\% de probabilidade. AD: Arado de discos; GA: Grade aradora intermediária; ES: Escarificador; ER: Enxada rotativa.

A RMSP aumenta ao longo do perfil do solo para todos os equipamentos de preparo convencional do solo, demonstrando que deve haver um manejo adequado para que esses valores mais altos não se tornem, ao longo do tempo, prejudiciais para a produtividade das culturas. Resultados similares foram encontrados por Pereira et al. (2002), Silva et al. (2017), Theodoro et al. (2018), Valente at al. (2019). Sendo afirmado que este maior valor é causado pela ação das máquinas e implementos. Entretanto, o valor de resistência à penetração diminui abaixo dos 0,4 m seguindo o demonstrado por Gamero \& Benez (1990), onde afirmam que abaixo dessa profundidade o efeito dos órgãos ativos dos equipamentos é diluído para a RMSP.

Para o arado de discos a camada de 0,2 - 0,3 $\mathrm{m}$ diferiu das demais e, tomando como base que não houve diferença para a umidade ao longo do perfil, pode-se afirmar que esta camada apresenta maior compactação (Tabela 1). Este tipo de observação é comumente encontrado em diversos trabalhos (Silva, 2015; Valente et al., 2019), e pode-se atribuir a isto o fato de ocorrer a formação de uma soleira, ou camada compactada, logo abaixo à ação dos órgãos ativos dos equipamentos agrícolas, comumente chamada de "pé de arado".

A grade aradora intermediária proporcionou menor valor de RMSP na camada 0,0 - 0,1 m se comparada com a camada abaixo de 0,1 m (Tabela 1). Isto pode ser explicado pelo fato da mobilização do solo realizada por este equipamento acontecer até a profundidade onde foi observado menor valor de resistência. Corroborando com o apresentado, Nagahama et al. (2016), observaram que a grade de discos de 0,56 m apresentou maior valor de RMSP na camada de 0,2 - 0,3 m se comparado aos demais equipamentos avaliados e, segundo os autores, este resultado é devido a menor profundidade de trabalho do equipamento. 
A camada de 0,0 - 0,1 $\mathrm{m}$ do preparo do solo realizado com o escarificador apresentou menor valor de RMSP se comparado com a camada 0,3-0,4 m, onde para ambas, o valor de umidade não diferiu (Tabela 1). 0 preparo de solo efetuado com o escarificador não promove compactação, entretanto a diferença apresentada pode ter sido pelo maior volume de raízes observado, efeito do preparo secundário ou do controle das plantas invasoras (realizada com a gradagem), onde a operação com esse equipamento proporciona a movimentação lateral do solo. Essa movimentação pode ter reduzido a resistência do solo à penetração na profundidade até $0,1 \mathrm{~m}$. Torres et al. (2015) encontraram maior valor de RMSP nas camadas abaixo da camada de 0,0 - 0,1 m para o preparo de solo realizado com o arado escarificador e afirmam que o valor encontrado é consequência da profundidade de ação do equipamento. No entanto, os valores encontrados estão abaixo de 2,5 MPa (Tabela 1), valor crítico, sugerido pela literatura, para o impedimento ao crescimento e desenvolvimento das raízes (Sene et al., 1985, Canarache, 1990, Camargo \& Alleoni, 1997).

0 uso do escarificador acarretou em maiores valores de resistência do solo à penetração na profundidade de 0,1 a 0,3 m se comparado à camada de 0,0 - 0,1 m, no entanto essas camadas não podem ser comparadas visto que o valor de umidade apresentou diferença significante (Tabela 1). A ocorrência de uma camada do solo menos úmida proporciona maior valor de RMSP em comparação com uma camada mais úmida, demonstrando a relação inversa entre a resistência à penetração e a umidade do solo. Tormena et al. (2004), observaram que o preparo de solo realizado com o escarificador trabalhando na profundidade de $0,3 \mathrm{~m}$ seguido de gradagem niveladora proporcionou maiores valores de RMSP na camada superficial se comparada com a camada subsuperficial, onde os autores explicam o ocorrido através do secamento do solo em superfície em relação ao solo em subsuperfície, ou seja, indicando a relação inversa.

A enxada rotativa mobiliza o solo intensamente, porém promove o preparo de solo em apenas uma operação (Torres et al., 2015). Devido essa mobilização intensa é esperado que a camada de solo em que ocorre o preparo apresente menor valor de RMSP e que abaixo a esta não ocorra diferença, como é apresentado na Tabela 1.

Pelos dados da Tabela 2 observa-se que não houve diferença significativa na densidade do solo para os tratamentos de preparo de solo em nenhuma camada de solo avaliada (como a RMSP), sendo o resultado característico para este tipo de estudo. Silva (2015), avaliando o efeito de cinco equipamentos de preparo de solo, sendo eles arado de discos, arado de aivecas, grade aradora intermediária, escarificador e enxada rotativa também não encontrou diferença significativa para a densidade do solo. Carvalho Filho et al. (2007) estudando diferentes sistemas de preparo de solo (plantio direto, escarificador, grade aradora, arado de discos e arado de aivecas) na interação com a densidade do solo obteve resultado semelhante para esta variável.

Tabela 2. Densidade do solo sob influência de diferentes métodos de preparo do solo em diferentes profundidades de avaliação ( $\mathrm{g} \mathrm{cm}-3$ )

\begin{tabular}{|c|c|c|c|c|c|}
\hline \multirow[b]{2}{*}{ Profundidade (m) } & \multicolumn{5}{|c|}{ Sistemas de preparo } \\
\hline & $\mathrm{AD}$ & GA & ES & ER & CV $(\%)$ \\
\hline $0,0-0,1$ & 1,05 с A & $1,10 \mathrm{~b} \mathrm{~A}$ & 1,09 с A & $1,02 \mathrm{~b} \mathrm{~A}$ & 3,94 \\
\hline $0,1-0,2$ & 1,24 a $\mathrm{A}$ & 1,23 a $A$ & 1,25 a $A$ & 1,21 a $\mathrm{A}$ & 3,90 \\
\hline $0,2-0,3$ & 1,25 a $A$ & 1,22 a $A$ & $1,22 \mathrm{ab} A$ & 1,21 a $A$ & 3,87 \\
\hline $0,3-0,4$ & 1,22 a $A$ & 1,20 a $A$ & $1,22 \mathrm{ab} A$ & 1,17 a $A$ & 2,96 \\
\hline $0,4-0,5$ & $1,18 \mathrm{ab} A$ & $1,15 \mathrm{ab} A$ & $1,18 \mathrm{ab} A$ & 1,14 a $\mathrm{A}$ & 3,05 \\
\hline $0,5-0,6$ & $1,12 \mathrm{bc} \mathrm{A}$ & $1,16 \mathrm{ab} A$ & $1,17 \mathrm{bc} \mathrm{A}$ & 1,15 a $\mathrm{A}$ & 3,41 \\
\hline CV $(\%)$ & 3,54 & 3,41 & 3,21 & 4,01 & \\
\hline
\end{tabular}

Médias seguidas de letras iguais minúsculas na coluna e maiúsculas na linha não diferem entre si pelo teste Tukey a 5\% de probabilidade. AD: Arado de discos; GA: Grade aradora intermediária; ES: Escarificador; ER: Enxada rotativa. 
Os equipamentos de preparo convencional do solo causaram diferentes valores de densidade ao longo do perfil do solo, sendo a camada de 0,0 - 0,1 m a que apresentou menor valor (Tabela 2). A partir da profundidade de 0,1 m é possível notar o aparecimento dos efeitos do preparo de solo, devido à ação dos órgãos ativos dos equipamentos agrícolas que por sua vez mobilizam a camada superficial de solo, reduzindo a densidade. A ocorrência de alterações na densidade do solo, e outros atributos físicos do solo, são comuns em ambientes agrícolas, independente do sistema de preparo de solo adotado (Costa et al., 2003).

O preparo periódico convencional promove a mobilização da camada superficial do solo, sendo assim os valores de densidade dessa camada são menores em comparação às camadas subsuperficiais. Além disso, Sales et al. (2016), afirmam que o sistema de plantio convencional promove menor compactação na camada superficial do solo em relação ao sistema de plantio direto na palha.

Todos os equipamentos causaram diferenças nos valores de densidade entre as camadas avaliadas (Tabela 2), porém o preparo de solo com o escarificador não causa compactação. Assim como a RMSP, o surgimento de uma camada de maior densidade pode ser relacionado com o controle de plantas daninhas ou com o preparo secundário do solo, efetuado com a grade destorroadora - niveladora, que ao executar a movimentação lateral do solo pode ter influenciado diretamente no valor encontrado na camada de 0,0 0,1 m. Cabral et al. (2015), avaliando o efeito do preparo de solo para a reforma de um canavial nos atributos físicos de um Neossolo Quartzarênico órtico, observaram que a subsolagem em área total apresentou menor valor de densidade do solo quando comparada a subsolagem em área total mais a gradagem niveladora, para a camada de 0,15 - 0,25 $\mathrm{m}$. De acordo com os autores isso é devido ao intenso revolvimento do solo provocado pelo segundo sistema de manejo, reduzindo, assim, a eficiência do rompimento da compactação quando comparado com o sistema de apenas uma operação.

Prevedello et al. (2013) também observaram menor valor de densidade na camada de 0,0 - 0,1 m se comparado com a camada $0,2-0,3 \mathrm{~m}$, para o preparo de solo realizado com o escarificador. Os autores afirmam que este resultado ocorreu pela mobilização do solo causada pelos equipamentos e incorporação dos resíduos vegetais que favoreceu a atividade da microbiota do solo e diminuiu o impacto do peso das máquinas. No entanto, de acordo com a Tabela 2, essa primeira camada de solo $(0,0-0,1 \mathrm{~m})$ avaliada não diferiu da última camada $(0,5-0,6 \mathrm{~m})$, profundidade onde os efeitos dos sistemas de preparo de solo são menores, conforme afirmam Gamero \& Benez (1990).

O fato da primeira camada de solo apresentar menor valor de densidade (Tabela 2) pode ser consequência de uma recuperação do solo aos efeitos de compactação nesta profundidade. Isso é explicado por Gubiani et al. (2015), onde afirmam que a contração e expansão do solo causada pela variação do teor de água promovem, de forma gradativa, reversão dos processos de compactação, redução da densidade do solo, e assim redução da compactação superficial. Corroborando com o apresentado, Cavichiolo (2005), Prevedello et al. (2013), afirmam que a recuperação da estrutura do solo na camada de 0,0 - 0,1 m é facilitada pela maior regularidade dos processos de secagem e umedecimento nesta profundidade. Além da ocorrência do maior volume de raízes das plantas.

A resistência à penetração e a densidade do solo demonstraram valores correspondentes, sendo que para ambas as variáveis não houve influência do sistema de preparo de solo. A primeira camada de solo avaliada apresentou menor valor tanto de RMSP, quanto de densidade do solo. Logo abaixo a ação dos equipamentos agrícolas ocorreu aumento dos valores das duas variáveis e abaixo da profundidade de 0,4 m, 0,5 m ocorreu uma redução.

Assim como a densidade e a RMSP, o preparo de solo efetuado por distintos equipamentos não influenciou a produtividade do feijão, a população final de plantas, o número de vagens por planta e o número de grãos por vagem (Tabela 3). Em valores absolutos, a produtividade, em todos os tratamentos, foi superior a 1,0 t ha-1, valor médio da safra brasileira para 2017/2018 (CONAB, 2019). A não interferência do preparo de solo na produtividade da cultura também foi observado por Bento (2004) e Carvalho Filho et al. (2007), sendo que para os autores o resultado poderia ser explicado pelo trabalho ter sido realizado em apenas um ano agrícola, contrapondo ao exposto neste trabalho, onde o cultivo de grãos é feito com os mesmos sistemas de preparo há cinco anos na área. 
Tabela 3. Produtividade em grãos, população final, número de vagens por planta e número de grãos por vagem da cultura do feijão

\begin{tabular}{|c|c|c|c|c|c|}
\hline \multirow{2}{*}{ Variáveis } & \multicolumn{5}{|c|}{ Sistemas de preparo de solo } \\
\hline & $\mathrm{AD}$ & GA & ES & ER & CV $(\%)$ \\
\hline $\begin{array}{l}\text { Produtividade } \\
\text { (kg/ha) }\end{array}$ & $1.572,52 \mathrm{a}$ & $1.757,22 \mathrm{a}$ & $2.131,60 \mathrm{a}$ & $1.417,61 \mathrm{a}$ & 24,82 \\
\hline $\begin{array}{l}\text { População final } \\
\text { (plantas/ha) }\end{array}$ & $240.000 \mathrm{a}$ & $217.500 \mathrm{a}$ & $260.000 \mathrm{a}$ & $212.500 \mathrm{a}$ & 12,75 \\
\hline $\begin{array}{c}\text { Número de } \\
\text { vagens/planta }\end{array}$ & $8,03 \mathrm{a}$ & 10,67 a & $10,90 \mathrm{a}$ & 9,05 a & 9,92 \\
\hline $\begin{array}{l}\text { Número de } \\
\text { grãos/vagem }\end{array}$ & $4,71 \mathrm{a}$ & 5,09 a & 5,07 a & $4,62 \mathrm{a}$ & 10,77 \\
\hline
\end{tabular}

Médias seguidas de mesma letra na linha não diferem entre si pelo teste Tukey (5\%). AD: Arado de discos; GA: Grade aradora intermediária; ES: Escarificador; ER: Enxada rotativa.

O número médio de vagens por planta e o número de grãos por vagem não variou em função do preparo de solo (Tabela 3). Stone \& Moreira (2000) avaliando os sistemas de preparo de solo nos componentes de produção do feijoeiro também não verificaram diferença entre os equipamentos utilizados no preparo convencional do solo. Porém, os autores encontraram diferença em relação ao plantio direto e convencional e explicam o fato pelo primeiro sistema proporcionar maior quantidade de cobertura morta e maior disponibilidade de água no solo. Silva (2015) avaliando o efeito do preparo do solo, também não verificou diferença para a produtividade, população final e número de vagens da cultura da soja.

\section{CONCLUSÕES}

Não foi observado efeito do preparo do solo na RMSP, densidade do solo e atributos agronômicos da cultura do feijão. No entanto, ao longo do perfil do solo foram verificados valores distintos de RMSP e densidade do solo, sendo que esses valores são menores na camada mobilizada pelo equipamento e aumenta na camada logo abaixo à mobilizada. Em maiores profundidades não é observado o efeito do preparo do solo nas variáveis físicas avaliadas. Os valores de RMSP são inferiores aos níveis críticos citados na literatura não influenciando, portanto, no desenvolvimento e produtividade do feijão. 0 intenso revolvimento do preparo secundário do solo pode reduzir a eficiência da descompactação realizada pelo escarificador.

\section{REFERÊNCIAS}

[1] ARATANI, R.G.; FREDDI, O.S.; CENTURION, J.F.; ANDRIOLI, I. Qualidade física de uma LATOSSOLO VERMELHO ACRIFÉRRICO sob diferentes sistemas de uso e manejo. Revista Brasileira de Ciência do Solo, 33:677-687, 2009.

[2] BENTO, E.O. Efeitos da compactação do solo na cultura da soja (Glycine max L.) sob diferentes sistemas de preparo. Ituverava: FEI/FAFRAM, 2004. 47 p. Trabalho de Conclusão de Curso (Graduação em Agronomia). Faculdade "Dr. Francisco Maeda", Fundação Educacional de Ituverava.

[3] BERTOL, I.; ALBUQUERQUE, J.A.; LEITE, D.; AMARAL, A.J.; ZOLDAN JUNIOR, W.A. Propriedades físicas do solo sob preparo convencional e semeadura direta em rotação e sucessão de culturas, comparadas às do campo nativo. Revista Brasileira de Ciência do Solo, v.28, p.155-163, 2004. 
[4] BEUTLER, A.N.; CENTURION, J.F. Compactação do solo no desenvolvimento radicular e na produtividade de soja. Pesquisa agropecuária brasileira, Brasília, v.39, n.6, p.581-8, 2004.

[5] BOWEN, H. D. Alleviating mechanical impedance. In: ARKIN, G. F. \& TAYLOR, H. M., (Ed.). Modifying the root environment to reduce crop stress. Michigan. p.18-57. 1981.

[6] CABRAL, M.C.M.; CARVALHO, L.A.; NOVAK, E.; SCHICARELLI, C.D.S. Sistema de preparo de solo em área de reforma de canavial e as alterações físicas do solo. Revista Agrarian, v.8, n.30, p.376-386, Dourados, 2015.

[7] CAMARGO, O.A.; ALLEONI, L.R.F. Compactação do solo e o desenvolvimento das plantas. Piracicaba: Escola Superior de Agricultura “Luiz de Queiroz”, Universidade de São Paulo, p.132, 1997.

[8] CAMPOS, B.C.; REINERT, D.J.; NICOLODI, R.; RUEDELL, J.; PETRERE, C. Estabilidade estrutural de um Latossolo Vermelho-Escuro distrófico após sete anos de rotação de culturas e sistemas de manejo de solo. Revista Brasileira de Ciência do Solo, 19:121-126, 1995.

[9] CANARACHE, A.P.A generalized semi-empirical model estimating soil resistance to penetration. Soil \& Tillage Research, Amsterdam, v.16, n.1, p.51-70, 1990.

[10] CARVALHO, A.M.X.; MENDES, F.Q. SPEED Stat: a minimalist and intuitive spreadsheet program for classical experimental statistics. Anais da 62 ${ }^{a}$ Reunião Anual da Região Brasileira da Sociedade Internacional de Biometria, 2017. 333pp.

[11] CARVALHO FILHO, A.; SILVEIRA, M.E.G.; SILVA, R.P.; CORTEZ, J.W. E CARVALHO, L.C.C. Efeitos de sistemas de preparo nas propriedades físicas de um Latossolo Vermelho acriférrico cultivado com milho. Scientia Agraria Paranaensis, v.6, n.1/2: p.31- 39, 2007.

[12] CAVICHIOLO, S.R. et al. Modificações nos atributos físicos de solos submetidos a dois sistemas de preparo em rebrota de Eucalyptus saligna. Revista Árvore, Viçosa, v. 29, n. 4, p. 571-577, jul./ ago. 2005.

[13] COLLARES, G.L.; REINERT, D.J.; REICHERT, J.M.; KAISER, D.R. Compactação de um LATOSSOLO induzida pelo tráfego de máquinas e sua relação com o crescimento e produtividade de feijão e trigo. Revista Brasileira de Ciência do Solo, v.32, p.933-942, 2008.

[14] COLLARES, G.L.; REINERT, D.J.; REICHERT, J.M.; KAISER, D.R. Qualidade física do solo na produtividade da cultura do feijoeiro num Argissolo. Pesquisa agropecuária brasileira, Brasília, v.41, n.11, p.1663-1674, nov. 2006.

[15] CONAB. Acompanhamento da safra brasileira de grãos. Disponível em: <file:///C:/Users/38551169/Downloads/GrosZabrilZ2019_completo.pdf>. Acesso em 8 abr. de 2019. 2019.

[16] COSTA, F.S.; ALBUQUERQUE, J.A.; BAYER, C.; FONTOURA, S.M.V.; WOBETO,C. Propriedades físicas de um LATOSSOLO BRUNO afetadas pelos sistemas plantio direto e preparo convencional. Revista Brasileira de Ciência do Solo, 27:527-535, 2003.

[17] EMBRAPA. EMPRESA BRASILEIRA DE PESQUISA AGROPECUÁRA. Manual de métodos de análise do solo. EMBRAPA/CNPSO. 212p. 1997.

[18] FALLEIRO R.M.; SOUZA, C.M.; SILVA, C.S.W.; SEDIYAMA, C.S.; SILVA, A.A.; FAGUNDES, J.L. Influência dos sistemas de preparo nas propriedades químicas e físicas do solo. Revista Brasileira de Ciência do Solo, 27:1097-1104, 2003.

[19] FREDDI, O.S.; CENTURION, J.F.; DUARTE, A.P. \& LEONEL, C.L. Compactação do solo e produção de cultivares de milho em Latossolo Vermelho. I-Características de planta, solo e índice S. Revista Brasileira de Ciência do Solo, 33:793-803, 2009.

[20] GAMERO, C.A.; BENEZ, S.H. Avaliação da condição do solo após a operação de preparo. In: SILVEIRA, G.M. IV Ciclo de estudos sobre mecanização agrícola. Jundiaí: Fundação Cargill, p.12-21. 1990.

[21] GUBIANI, P.I.; LIER, Q.J.V.; DRESCHER, M.S.; MEZZOMO, H.C.; VEIGA, C.M.C. Relação entre densidade do solo e conteúdo de água em repetidos ciclos de contração e expansão em um latossolo. Revista Brasileira de Ciência do Solo, Viçosa, 39:100-108, 2015.

[22] MARSCHNER, H. Mineral nutrition of higher plants. 2.ed. London, Academic Press, p.508-536, 1995.

[23] MÜLLER, M.M.L.; CECCON, G. \& ROSOLEM, C.A. Influência da compactação do solo em subsuperfície sobre o crescimento aéreo e radicular de plantas de adubação verde de inverno. Revista Brasileira de Ciência do Solo, 25:531$538,2001$.

[24] NAGAhAMA, H.J.; CORTEZ, J.W.; PIMENTA,W. A.; PATRocíniO FILHO, A.P.; SOUZA, E.B. de. Sistemas de preparo e velocidade de deslocamento de conjuntos mecanizados em atributos do solo. Revista Agrarian, v.9, n.34, p. 357-364, Dourados, 2016.

[25] ORTIGARA, C.; KOPPE, E.; LUZ, F.B.; BERTOLLO, A.M.; KAISER, D.R.; SILVA, V.R. Uso do solo e propriedades físico-mecânicas de Latossolo Vermelho. Revista Brasileira de Ciência do Solo, v. 38, p. 619-626, 2014. 
[26] PEREIRA, J.O.; SIQUEIRA, J.A.C., URIBE-OPAZO, M.A.; SILVA, S.L. Resistência do solo resistência do solo à penetração em função à penetração em função do sistema de cultivo do sistema de cultivo e teor de água do solo. Revista Brasileira de Engenharia Agrícola e Ambiental, v. 6, n. 1, p. 171-174, 2002.

[27] PREVEDELLO, J., KAISER, D.R., REINERT, D.J., VOGELMANN, E.S., FONTANELA, E., \& REICHERT, J.M. (2013). Manejo do solo e crescimento inicial de Eucalyptus grandis Hill ex Maiden em Argissolo. Ciência Florestal, Santa Maria, 23 (1), 129-138.

[28] QUEIROZ-VOLTAN, R.B.; NOGUEIRA, S.S.S.; MIRANDA, M.A.C. Aspectos da estrutura da raiz e do desenvolvimento de plantas de soja em solos compactados. Pesquisa agropecuária brasileira, Brasília, v.35, p.929-938, 2000.

[29] SÁ, J.C.M. Reciclagem de nutrientes dos resíduos culturais, e estratégia de fertilização para a produção de grãos no sistema plantio direto. In: SEMINÁRIO SOBRE O SISTEMA PLANTIO DIRETO NA UFV, 1., Viçosa, 1998. Resumo das palestras. Viçosa, Universidade Federal de Viçosa, 1998. p.19-61.

[30] SALES, R.P.; PORTUGAL, A.F.; MOREIRA, J.A.A.; KONDO, M.K.; PEGORARO, R.F. Qualidade física de um Latossolo sob plantio direto e preparo convencional no semiárido. Revista Ciência Agronômica, v. 47, n. 3, p. 429-438, jul-set, 2016

[31] SANTIAGO, A.D.; ROSSETTO, R. (2007). Preparo Convencional. AGEITEC, Agência Embrapa de Informação Tecnológica. Disponível em: < http://www.agencia.cnptia.embrapa.br/gestor/cana-deacucar/arvore/CONTAG01_84_22122006154841.html\#> Acesso em 02 abr. 2019.

[32] SENE, M. et al. Relationships of soil texture and structure to corn yield response to subsoiling. Soil Science Society of America Journal, Madison, v.49, n.2, p.422-427, 1985.

[33] SILVA, F.J.; OLIVEIRA, C.A.A.; ALMEIDA, L. S.; LIMA, L.P.; GUIMARÃES, E.C. Variabilidade espacial da resistência do solo à penetração e produtividade do milho. Revista de Agricultura Neotropical, Cassilândia-MS, v. 4, n. 3, p. 77-84, jul./set. 2017.

[34] SILVA, R.B.; DIAS JÚNIOR, M.S.; SANTOS, F.L.; FRANZ, C.A.B. Resistência ao cisalhamento de um Latossolo sob diferentes usos e manejos. Revista Brasileira de Ciência do Solo, v.29, n.1, p.165-173, 2004.

[35] SILVA, Urbano Teixeira Guimarães. Efeito do sistema de preparo em algumas propriedades físicas do solo e na cultura da soja. 2015. 91f. Dissertação (Mestrado em Agronomia - Produção Vegetal) - Universidade Federal de Viçosa, Rio Paranaíba. 2015.

[36] SILVA, V.R.; REINERT, D.J.; REICHERT, J.M. Densidade do solo, atributos químicos e sistema radicular do milho afetados pelo pastejo e manejo do solo. Revista Brasileira de Ciência do Solo, vol. 24, núm. 1, 2000, pp. 191-199, 2000.

[37] STOLF, R. Fórmulas de transformação dos dados de penetrômetro de impacto em força/unidade de área. In: CONGRESSO BRASILEIRO DE ENGENHARIA AGRÍCOLA, 19, 1990, Piracicaba. Anais... Piracicaba: Sociedade Brasileira de Engenharia Agrícola, 1990. Vol. II, p. 823-37.

[38] STONE, L.F., MOREIRA, J.A.A. Resposta do feijoeiro ao nitrogênio em cobertura, sob diferentes lâminas de irrigação e preparo do solo. In: REUNIÃO NACIONAL DE PESQUISA DE FEIJÃO, 6, 2000, Anais...Salvador.

[39] STONE, L.F.; SILVEIRA, P.M. Efeitos do sistema de preparo e da rotação de culturas na porosidade e densidade do solo. Revista Brasileira de Ciência do Solo, vol. 25, №. 2, pp. 395-401, 2001.

[40] THEODORO, G.F.; GOLIN, H.O.; REZENDE, R.P.; ABREU, V.L.S.; SILVA, M.S. Influência de sistemas de preparo na manutenção da palhada e resistência do solo à penetração. Revista de Agricultura Neotropical, v. 5, n. 2, p. 25-30, 2018.

[41] TORMENA, C.A.; FRIEDRICH, R.; PINTRO, J.C.; COSTA, A.C.S.; FIDALSKI, J. Propriedades físicas e taxa de estratificação de carbono orgânico num latossolo vermelho após dez anos sob dois sistemas de manejo. Revista Brasileira de Ciência do Solo, 28:1023-1031, 2004.

[42] TORMENA, C.A.; SILVA, A.P.; LIBARDI, P.L. Caracterização do intervalo hídrico ótimo de um Latossolo Roxo sob plantio direto. Revista Brasileira de Ciência do Solo, v.22, p.573-581, 1998.

[43] TORRES, J.L.R.; NETTO, A.A.; SOUZA, Z.M.; ASSIS, R.L. Alterações causadas nos atributos físicos após preparo do solo com arado escarificador e enxada rotativa. Magistra, Cruz das Almas - BA, v. 27, n. 3/4, p. 316-325, Jul./Dez.2015.

[44] VALADÃO, F.C.A.; WEBER, O.L.S.; VALADÃO JÚNIOR, D.D.; SANTN, M.F.M.; SCAPINELLI, A. Teor de macronutrientes e produtividade da soja influenciados pela compactação do solo e adubação fosfatada. Revista de Ciências Agrárias, v.40(1), p.183-195, 2017.

[45] VALENTE, G.F.; SILVA, V.F.A.; SILVA, J.N. da; PINTO, D.R.S; GALVÃO, J.R. Resistência mecânica à penetração em sistemas de manejo do solo. Revista Verde, v.14, n.1, p.140-145, 2019. 


\section{Capítulo 10}

\section{Regionalização do vigor de plantas através do uso de séries históricas de imagens orbitais}

\section{Leandro Maria Gimenez \\ Davi Gabriel Azevedo Besson}

Resumo: A variabilidade espacial das lavouras pode levar a dificuldades no manejo e em última análise a perdas de produtividade. Diversas técnicas podem ser empregadas para caracterizar variabilidade espacial do desempenho das culturas, merecendo destaque os monitores de colheita embarcados nas colhedoras e que permitem obter mapas de produtividade. Em muitas circunstâncias não há disponibilidade dessas informações e uma alternativa é o uso de imagens orbitais. Estas devem, entretanto, ser corretamente selecionadas e processadas para que possam contribuir à compreensão da variabilidade espacial. Para a definição de estratégias de manejo da variabilidade espacial é interessante estabelecer unidades que apresentem comportamento semelhante ao longo das safras, ou seja, sem variabilidade temporal. 0 emprego de estratégias para delimitação de grupos pode ser aplicado às imagens orbitais, havendo métodos supervisionados e não supervisionados. Este capítulo visa descrever uma metodologia passo a passo para obtenção de grupos homogêneos a partir de imagens orbitais. Tais grupos podem constituir as denominadas unidades de manejo, de grande valor para a agricultura de precisão por permitirem melhor compreensão acerca dos fatores que causam a variabilidade.

Palavras-chave: Agricultura de precisão, análise de agrupamento, unidade de manejo. 


\section{INTRODUÇÃO}

Diversos fatores influenciam o desempenho das culturas ao longo das áreas de produção, sendo recorrente a presença de variabilidade espacial. Essa variação ao longo de uma lavoura, é resposta da interação entre fatores físicos, químicos e fisiológicos, tanto da planta como do ambiente onde a cultura se desenvolve (DAINESE et al., 2006). O desconhecimento sobre a variabilidade leva a tratamentos uniformes, comprometendo a produtividade.

A agricultura de precisão (AP) é uma forma de gestão da lavoura que considera a sua heterogeneidade e visa tirar proveito disso. 0 mapa de produtividade, obtido através de equipamentos instalados nas colhedoras, pode ser o ponto de partida dos usuários e pesquisadores que buscam caracterizar a variabilidade espacial das lavouras. Apesar da sua importância, a coleta adequada de dados para gerar mapas de produtividade não ocorre na maior parte das vezes.

Nesse sentido é importante empregar alternativas para caracterizar a variabilidade espacial da cultura. 0 sensoriamento remoto através de imagens orbitais, permite realizar análises não-destrutivas e de baixo custo que podem complementar e auxiliar na tomada de decisão para manejo das culturas (SHIRATSUCHI et al., 2014). Um dos produtos do sensoriamento remoto que tem sido utilizado na previsão de safra e produtividade de culturas é o índice de vegetação por diferença normalizada (IVDN) ou mais comumente NDVI - Normalized Difference Vegetation Index), determinado através de relações de refletância do dossel da vegetação para as bandas do vermelho e do infravermelho (MOTTA et al., 2003). Atualmente, o NDVI pode ser obtido de imagens provenientes do sensor OLI (Operational Land Imager) a bordo do satélite Landsat 8, com resolução espacial de 30 m (USGS, 2013). Uma gama de imagens que permitem a obtenção do NDVI foi gerada por versões anteriores desta mesma família de satélites havendo também outros satélites capazes de fornecer estes produtos.

Diversos índices de vegetação têm sido propostos na literatura, com objetivo de explorar as propriedades espectrais da vegetação, especialmente na região do visível e infravermelho próximo. Estes índices são relacionados a parâmetros biofísicos da cobertura vegetal, como biomassa e índice de área foliar (IAF), além de minimizarem os efeitos de iluminação da cena, declividade da superfície e geometria de aquisição que influenciam os valores de refletância da vegetação. (PONZONI \& SHIMABUKURO, 2007).

Embora na maior parte das vezes haja uma relação entre o vigor de plantas expresso através do NDVI e a produtividade das culturas, eventos atmosféricos, principalmente a nebulosidade, ocorridos no estágio fenológico da cultura que deve ser imageada comprometem esta relação, devendo ser utilizados dados históricos para atenuar este efeito, impedindo o uso da informação para tomada de decisão em curto prazo. DIKER et al. (2004) estudando a variabilidade da produção de milho em dois campos demonstraram que apesar da distribuição espacial ter se modificado durante as três safras, a análise da repetitividade da produtividade de cada ano permitiu identificar três regiões em relação à média da produtividade temporal. Por outro lado, estudos desenvolvidos para compreender os padrões da variabilidade espacial e perceber como esta é afetada pela variabilidade temporal, como aquele de GRIFO e SILVA (2013), verificaram que situações alternadas de anos secos e úmidos alteram a distribuição espacial da produção ao longo dos anos, devido à diferente disponibilidade de água.

Existe uma persistência na variabilidade do desempenho das culturas agrícolas, sendo vários os fatores que ocorrem dentro do campo de produção contribuintes para que isso ocorra como, relevo, exposição solar, profundidade dos horizontes, textura, capacidade de armazenagem de água, entre outras, que sendo atreladas ao clima podem dificultar um desempenho homogêneo da área como descrito em SCHEPERS et al. (2005) e SCHWALBERT et al. (2014). Nestas áreas com grande dinâmica temporal, através de um respaldo dos dados do sensoriamento remoto (SR), pode-se obter uma regionalização robusta do vigor das plantas nos campos de produção (THENKABAIL, 2003), que se constitui em informação básica para definir a necessidade de investimentos no manejo da variabilidade espacial, evitando gastos desnecessários com amostragens sistemáticas e equipamentos.

Considerando a importância da variabilidade espacial sobre o desempenho das culturas e a disponibilidade de informações históricas de sensores orbitais que permitem inferir sobre este fator, o objetivo desse capítulo é apresentar o processo de obtenção de indicadores sobre o número mínimo de imagens a serem utilizadas para a regionalização do vigor de plantas de soja. São apresentados estudos de caso de duas regiões com características de solo e clima distintas. Após a obtenção e processamento das imagens é demonstrada uma metodologia de análise de agrupamento para obtenção de classes de vigor. 


\section{DESENVOLVIMENTO}

Foram utilizadas imagens oriundas de glebas com histórico de cultivo de soja ou milho, há pelo menos 15 anos. Como requisito, as áreas não podem ter recebido práticas de manejo regionalizadas que acabariam por alterar a variabilidade espacial, inviabilizando avaliação da estabilidade temporal. Dados de época de semeadura e colheita das culturas devem ser obtidos do histórico de produção das fazendas, bem como informações adicionais como a ocorrência de eventos climáticos anormais.

Para a utilização de uma imagem multiespectral, deve ser considerado que a radiação eletromagnética captada por sensores remotos é influenciada pelos gases e aerossóis quando de sua trajetória pela atmosfera no percurso fonte - alvo - sensor. Assim, para se obter valores de refletância e radiância de superfícies vegetais, a partir dos números digitais (NDs) de uma imagem, a variabilidade nas condições atmosféricas também deve ser considerada (MACHAD0, 2003). Além disso, não se pode comparar NDs de bandas diferentes, tanto para um mesmo sensor quanto para sensores diferentes, pois cada banda de cada sensor possui um critério próprio para discriminar os valores de radiância medidos na escala específica de sua resolução radiométrica.

Dessa forma, a transformação de NDs de uma imagem multiespectral em valores físicos, radiância ou refletância, é um processo importante para a caracterização espectral de objetos e em operações matemáticas entre diferentes bandas ou sensores, como na criação dos índices de vegetação. Após os processos de tratamento das imagens, a correção atmosférica permite obter imagens cujos pixels têm seus atributos expressos em Refletância de superfície (R superfície), sendo possível a caracterização espectral dos alvos de interesse na superfície terrestre (SCHOWENGERDT, 2006).

As imagens orbitais ou arquivos raster são formados por uma matriz de pixels (também chamados de células), cada uma contendo um valor que representa uma condição da área coberta por essa célula. A utilização de arquivos raster é muito utilizada para representar grandes áreas com mudança de valores contínua, ou seja, a variabilidade temporal e espacial dos atributos da área (cobertura vegetal, solo, etc.). 0 tamanho dos pixels determina a resolução espacial e o número de bandas espectrais que compõem a imagem determina a resolução espectral, sendo as imagens compostas por várias bandas denominadas de multiespectrais (PONZONI \& SHIMABUKURO, 2007).

As imagens raster utilizadas neste trabalho foram obtidas nos portais do serviço geológico norte americano (USGS) e do Instituto Nacional de Pesquisas Espaciais (INPE) correspondentes ao sensor TM (Thematic Mapper) e OLI (Operational Land Imager) embarcados nos satélites Landsat 5 e 8, respectivamente. Foi selecionada uma cena para cada safra em cada talhão, em período próximo ao estágio de máximo desenvolvimento vegetativo, mas pelas dificuldades de encontrar imagens sem nebulosidade, houve a necessidade de optar por imagens com uma variação dentro do ciclo. As imagens foram tratadas realizando a correção radiométrica e georeferenciamento para realizar o cálculo do NDVI, conforme proposto por ROUSE et al. (1973).

A partir das imagens de refletância nas bandas do vermelho e infravermelho corrigidas foi obtido o plano de informação do NDVI e os processamentos para extração de classes de agrupamentos.

Proposto por ROUSE et al. (1973), o índice de vegetação da diferença normalizada (NDVI), para alvos terrestres no limite inferior aproxima-se de zero (0) e em seu limite superior aproximadamente 0,80. 0 cálculo para normalização é realizado através da equação 1:

$$
\mathrm{NDVI}=(\rho \mathrm{IVP}-\rho \mathrm{V}) /(\rho \mathrm{IVP}+\rho \mathrm{V})
$$

Em que:

$\mathrm{IVP}=$ refletância no infravermelho próximo

$\rho \mathrm{V}=$ refletância no vermelho

Trata-se de um índice amplamente utilizado para acompanhar o perfil sazonal e fenológico, duração do período de crescimento, pico de crescimento, entre outros. Vale salientar, que apesar do sucesso de sua aplicação em vegetação, para sua interpretação devem ser levadas em consideração limitações como o ponto de saturação que se manifesta de forma diferenciada para as bandas do vermelho e infravermelho próximo, interferência atmosférica, posicionamento do centro e largura de cada banda (vermelho e infravermelho próximo) que varia entre sensores. Destaca-se que a saturação dos valores de refletância na 
região do vermelho e infravermelho próximo durante o desenvolvimento da vegetação limita fortemente o comportamento esperado do índice em relação a densidade da cobertura vegetal, sendo a refletância de dosséis vegetais nessas bandas influenciada por sombras, além de parâmetros biofísicos da cultura. Dessa forma, a relação esperada entre o NDVI e a biomassa, por exemplo, pode não ser identificada para alguns tipos de cobertura vegetal ou ângulos de observação e de iluminação, conforme relatado em (PONZONI \& SHIMABUKURO, 2007).

Para o desenvolvimento da metodologia, arquivos de dados raster foram obtidos a partir de cada imagem de uma gleba em Chapadão do Céu - GO e uma em Nova Mutum - MT. Optou-se pelo milho para garantir a disponibilidade de imagens, dado que no período de desenvolvimento desta cultura, em segunda safra após a safra principal de soja, ocorre menor cobertura de nuvens.

Realizou-se a análise estatística descritiva e a remoção de valores discrepantes, considerados aqueles acima da média adicionada ou subtraída de três desvios padrão.

Os arquivos da mesma área foram unidos em uma planilha eletrônica e os valores de NDVI foram normalizados dentro de cada safra e talhão utilizando a equação abaixo:

$$
X_{\text {norm }}=\frac{X-X \min }{X \max -X \min } \times 100
$$

Em que:

$$
\begin{aligned}
& X_{\text {norm }}=\text { valor do pixel normalizado } \\
& X=\text { valor atual } \\
& X \min =\text { menor valor } \\
& X \max =\text { maior valor }
\end{aligned}
$$

Um número mínimo de imagens deve ser empregado para estabelecer quatro regiões através da classificação apresentada na Tabela 1, calculada para cada pixel da imagem, gerando um plano de informação referência de classe de vigor para cada unidade.

A título de exemplificar a importância de um número adequado de imagens a mesma classificação foi realizada empregando 2, 3, 4 e 5 imagens com três repetições para cada combinação, sendo cada combinação formada por imagens tomadas aleatoriamente dentre 6 imagens totais do banco de informação, Tabela 1.

Tabela 1. Classes de vigor de plantas em cada pixel de imagens orbitais do NDVI normalizado por safra e local

\begin{tabular}{|l|c|c|}
\multicolumn{1}{c}{ Classe } & \multicolumn{1}{c|}{ Média* $^{*}$} & $\begin{array}{c}\text { Coeficiente de } \\
\text { Variação* }\end{array}$ \\
\hline Instável & Indiferente & Acima de 15\% \\
\hline Maior Vigor & Maior que 80 & Menor que 15\% \\
\hline Vigor Intermediário & Entre 50 e 80 & Menor que 15\% \\
\hline Menor Vigor & Menor que 50 & Menor que 15\% \\
\hline \multicolumn{2}{|c|}{${ }^{*}$ Calculado a partir de 6 imagens. } \\
\hline
\end{tabular}

Os dados de NDVI normalizados utilizados para a classificação através de valores médios e do coeficiente de variação devem ser submetidos à análise por meio de algoritmos de agrupamento, ou cluster. Segundo FRIDGEN et al. (2004), a análise de agrupamento classifica indivíduos distintos em classes diferentes. No processo de classificação foi utilizado o algoritmo Fuzzy k-means. O processo de agrupamento realizado pelos algoritmos começa com médias arbitrárias sendo estabelecidas, pelo programa para cada agrupamento. Como dados de entrada indicou-se 2 e 8 respectivamente, para o número mínimo e máximo de agrupamentos a serem criados, sendo uma escolha arbitrária assumindo-se que 8 classes seria um limite máximo para classes de vigor com alguma aplicabilidade. Em seguida definiu-se o número máximo de interações (300), o expoente fuzzy (1,3), o critério de encerramento da análise $(0,0001)$ e o tipo de 
distância utilizada entre as observações e o centroide de cada classe (euclidiana), (CASTRO, 2004). A informação resultante dessa análise, obtida com o auxílio do software FuzME (MINASNY\&MCBRBRATNEY, 2000), é utilizada para criar os mapas de superfície com os agrupamentos estabelecidos. Para a determinação do número ótimo de classes de agrupamentos, são utilizados o índice de desempenho Fuzzy (FPI : " Fuzziness Performance Index") e a partição da entropia modificada (MPE: "Modified Partition Entropy"), sendo o número ideal de classes aquele em que esses índices atingem o mínimo (FRIDGEN et al., 2000).

\section{RESULTADOS}

Conforme apresentado na Tabela 2, após a transformação radiométrica dos dados observa-se alteração dos valores de NDVI demonstrand0 a importância de se realizar a correção radiométrica quando se faz análises quantitativas, como por exemplo, a utilização dos índices de vegetação para predizer produtividade, estádio de desenvolvimento das plantas, IAF (PONZONI \& SHIMABUKURO, 2007).

Tabela 2. Estatística descritiva dos valores de NDVI com e sem correção radiométrica, obtida da safra 2008 em Chapadão do Céu - GO.

\begin{tabular}{|l|c|c|}
\multicolumn{2}{c}{ Estatística } & \multicolumn{2}{c|}{ Índice de Vegetação, NDVI } \\
\hline Média & 0,531 & 0,670 \\
\hline Mediana & 0,517 & 0,662 \\
\hline Mínimo & 0,091 & 0,260 \\
\hline Máximo & 0,757 & 0,850 \\
\hline Desvio Padrão & 0,1 & 0,1 \\
\hline Assimetria & $-0,0$ & $-0,2$ \\
\hline Curtose & 0,0 & 0,3 \\
\hline Coef. de variação \% & 18,7 & 12,4 \\
\hline
\end{tabular}

No histograma da Figura 1, observa-se uma distribuição próxima àquela característica de uma distribuição normal dos dados de NDVI. Os dados são oriundos da safra de 2008 da produção de soja localizada em Chapadão do céu - GO, e apresentam uma pequena assimetria negativa.

Figura 1. Histograma dos dados de NDVI com e sem correção radiométrica.

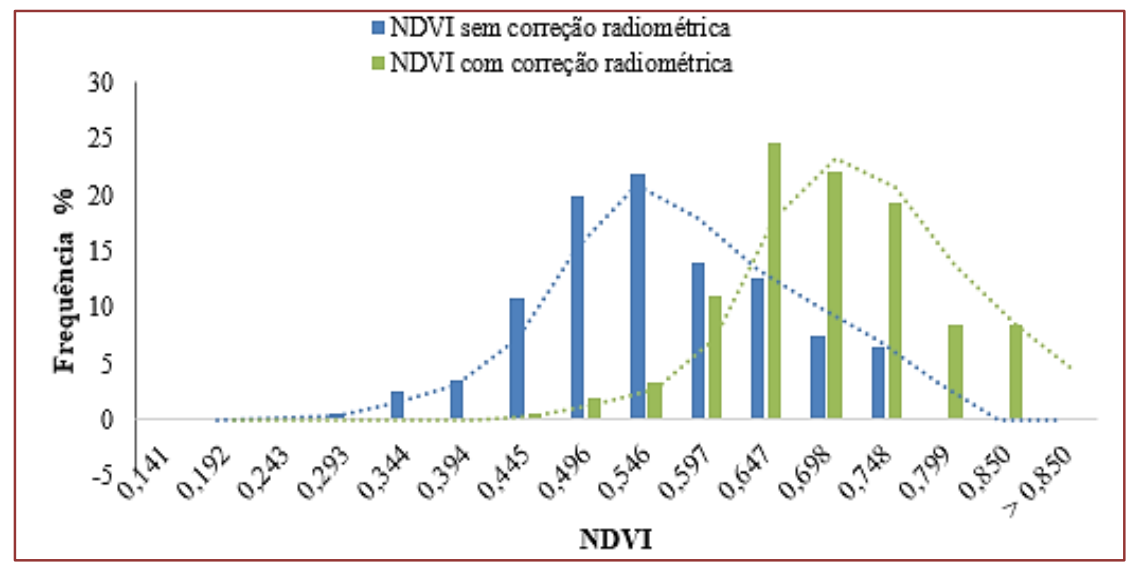

Nas Tabelas 3 e 4 são apresentados os resumos estatísticos para a variável NDVI de com os brutos e aqueles com filtragem e normalização, respectivamente, sendo os dados de NDVI obtidos através de imagens do mês de maio de uma área de produção de milho segunda safra, localizada em Nova Mutum MT e os dados discrepantes, foram considerados como aqueles valores adicionados ou subtraídos de três desvios em relação à média, dentro de cada safra/imagem. 
Tabela 3. Estatística descritiva dos dados de NDVI antes do processamento.

\begin{tabular}{|l|c|c|c|c|c|c|}
\hline \multicolumn{1}{c}{ Estatística } & \multicolumn{6}{c|}{ Valores para os índices de vegetação NDVI em função da safra } \\
& 2007 & 2008 & 2009 & 2010 & 2014 & 2015 \\
\hline № de pixels & 4560 & 4560 & 4560 & 4560 & 4560 & 4560 \\
\hline Mínimo & 0,426 & 0,473 & 0,494 & 0,537 & 0,393 & 0,465 \\
\hline Máximo & 0,806 & 0,825 & 0,841 & 0,842 & 0,865 & 0,850 \\
\hline Média & 0,756 & 0,792 & 0,810 & 0,810 & 0,843 & 0,819 \\
\hline Mediana & 0,759 & 0,796 & 0,815 & 0,815 & 0,850 & 0,824 \\
\hline Assimetria & $-3,4$ & $-5,2$ & $-5,7$ & $-5,0$ & $-7,0$ & $-5,2$ \\
\hline Curtose & 24,0 & 35,6 & 47,4 & 33,8 & 63,3 & 53,1 \\
\hline Variância & 0,0006 & 0,0007 & 0,0005 & 0,0006 & 0,0009 & 0,0006 \\
\hline Desvio Padrão & 0,0 & 0,0 & 0,0 & 0,0 & 0,0 & 0,0 \\
\hline Coef. de variação \% & 3,3 & 3,3 & 2,8 & 3,0 & 3,6 & 2,9 \\
\hline
\end{tabular}

Observando o resumo estatístico das Tabelas 3 e 4, percebe-se que a normalização e filtragem dos dados aumentou a amplitude e variância além do coeficiente de variação, que vai de 13,8 \%, considerado médio, até $23,4 \%$, valor considerado alto (GOMES, 2000). A normalização e filtragem auxiliam na identificação de classes de vigor dentro do talhão.

Tabela 4. Estatística descritiva dos dados de NDVI após o processamento.

\begin{tabular}{|l|c|c|c|c|c|c|}
\hline \multirow{2}{*}{ Estatística } & \multicolumn{7}{c|}{ Valores para os índices de vegetação NDVI filtrados e } \\
& \multicolumn{7}{c|}{$\begin{array}{c}\text { normalizados } \\
\text { em função da safra }\end{array}$} \\
\cline { 3 - 8 } & 2007 & 2008 & 2009 & 2010 & 2014 & 2015 \\
\hline № de pixels & 4479 & 4451 & 4458 & 4461 & 4480 & 4501 \\
\hline Mínimo & 0,0 & 0,0 & 0,0 & 0,0 & 0,0 & 0,0 \\
\hline Máximo & 100,0 & 100,0 & 100,0 & 100,0 & 100,0 & 100,0 \\
\hline Média & 61,4 & 73,4 & 71,7 & 72,5 & 83,6 & 71,2 \\
\hline Mediana & 62,4 & 74,8 & 73,4 & 75,4 & 86,4 & 75,2 \\
\hline Curtose & 0,8 & 8,9 & 6,4 & 7,2 & 12,0 & 2,3 \\
\hline Assimetria & $-0,7$ & $-2,4$ & $-1,9$ & $-2,3$ & $-2,8$ & $-1,5$ \\
\hline Variância & 196,8 & 142,1 & 134,8 & 177,8 & 133,8 & 277,0 \\
\hline Desvio Padrão & 14,0 & 11,9 & 11,6 & 13,3 & 11,6 & 16,6 \\
\hline Coef. de variação \% & 22,9 & 16,2 & 16,2 & 18,4 & 13,8 & 23,4 \\
\hline
\end{tabular}

Uma média 530 de pixels foram removidos das seis safras, representando 2,0 \% da quantidade total, o que promoveu uma diminuição na assimetria e curtose, com maior aproximação da distribuição normal para todas as safras. Para a discriminação dos dados em classes é recomendável manter o mesmo número de dados em todas as safras, assim, além da eliminação dos valores discrepantes de uma safra, os dados com mesma localização das outras safras devem ser removidos. Dessa forma, cada pixel classificado é obtido a partir de seis pixels com valores de NDVI.

Na Figura 2 são ilustrados 6 mapas de NDVI, de milho cultivado em segunda safra na área utilizada para a apresentação da metodologia, em Nova Mutum, estado do Mato Grosso. Não é possível visualizar variabilidade expressiva no vigor das plantas dentro de cada safra, sendo um dos motivos a insensibilidade do índice de vegetação NDVI em mostrar essa variabilidade em função da quantidade de biomassa que leva à saturação do índice. Outra possibilidade é que a área apresenta naturalmente uma baixa variabilidade espacial e temporal. Comparando a variabilidade de vigor entre as safras, percebe-se um menor vigor para a safra de 2007 e um maior vigor para 2014, tendo no restante das safras um comportamento intermediário. 
Figura 2. Imagens raster de NDVI obtido em talhão com $2^{a}$ safra de Milho localizado em Nova Mutum - MT.

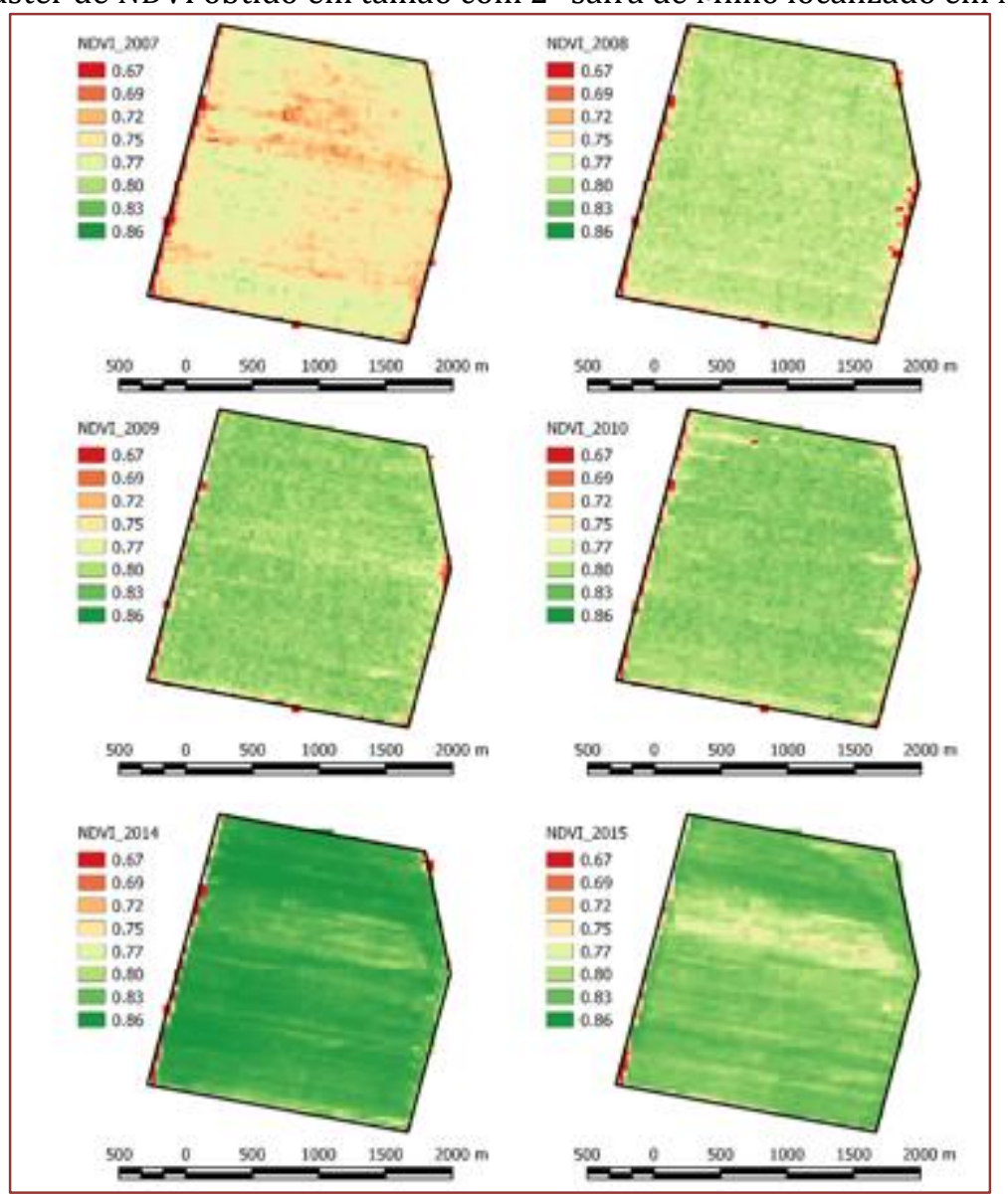

A Figura 3 ilustra o resultado da junção dos 6 mapas disponíveis, sendo formado o plano de informação referência para a cultura do milho na unidade experimental de Nova Mutum. Nesse mapa não houve pixels classificados como "menor vigor", pois esses pixels apresentaram coeficiente de variação acima de 15\%, assim foram classificados como fazendo parte da classe instável. A maior parte do talhão foi classificada na classe instável $(44,7 \%$ da área total), seguida da classe de vigor intermediário com 32,2 \%, 23,1 \% para a classe de maior vigor não sendo identificadas porções na classe considerada de menor vigor. Os valores com menor vigor apresentaram coeficiente de variação elevado devido à alta variabilidade temporal nesses locais do talhão.

Com a ressalva de que o universo amostral é baixo, ou seja, apenas 6 imagens, o resultado dos sorteios demonstrou que com o aumento do número de imagens na combinação, aumentou o número de pixels classificados corretamente. Os sorteios com duas imagens apresentaram desde, 58\% e 60\% de acerto, até $29 \%$ de acertos, mostrando grande inconstância e não repetitividade dos resultados. A partir da combinação de 3 imagens, o percentual médio de acertos situa-se próximo a 70\%, oferecendo maior consistência e confiança na utilização de 3, 4 e 5 imagens. Na Figura 3 são apresentados os mapas de classes de vigor para os sorteios. 
Figura 3. Mapa de classes de vigor para cada sorteio.

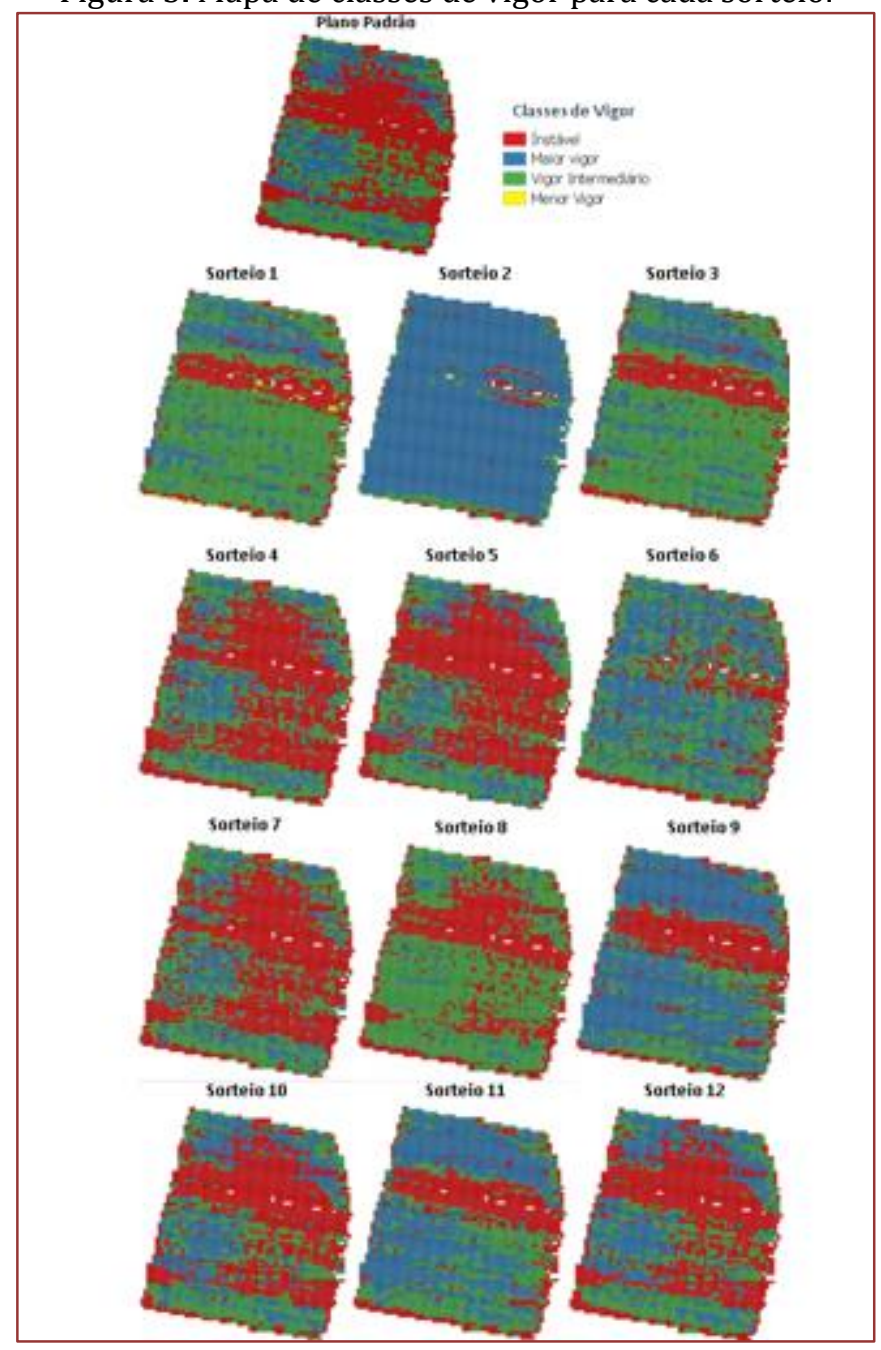

Para exercitar a classificação para a cultura da soja foram obtidas imagens de dois talhões no estado de São Paulo (Talhão C e Talhão Asfalto), nos municípios de Itararé e dois no Estado da Bahia (Talhão 8 e Talhão Frente) em Luis Eduardo Magalhães. Foram levantadas imagens disponíveis para os meses de interesse para imageamento, considerando os períodos de novembro a fevereiro para região sudeste e de dezembro a março para região nordeste. Essa busca demonstrou que embora para os talhões da Bahia, houvesse um histórico de 15 anos de cultivo de soja, apenas em quatro safras foram obtidas imagens sem cobertura de nuvens. Da mesma forma, para os talhões do estado de São Paulo, do histórico de 10 anos rastreados apenas 3 imagens foram utilizadas.

Dentre os fatores que impossibilitam o uso de imagens estão as condições de nebulosidade no período de interesse no imageamento e problemas operacionais ou de manejo, como datas de plantio diferentes no mesmo talhão e uso de culturas ou cultivares diferentes em pequenas porções das áreas. Algumas safras que apresentaram esses problemas são apresentadas na Figura 4. 
Figura 4. Ilustração de imagens com problemas que inviabilizaram sua utilização para os talhões de São Paulo (A) e talhões da Bahia (B).
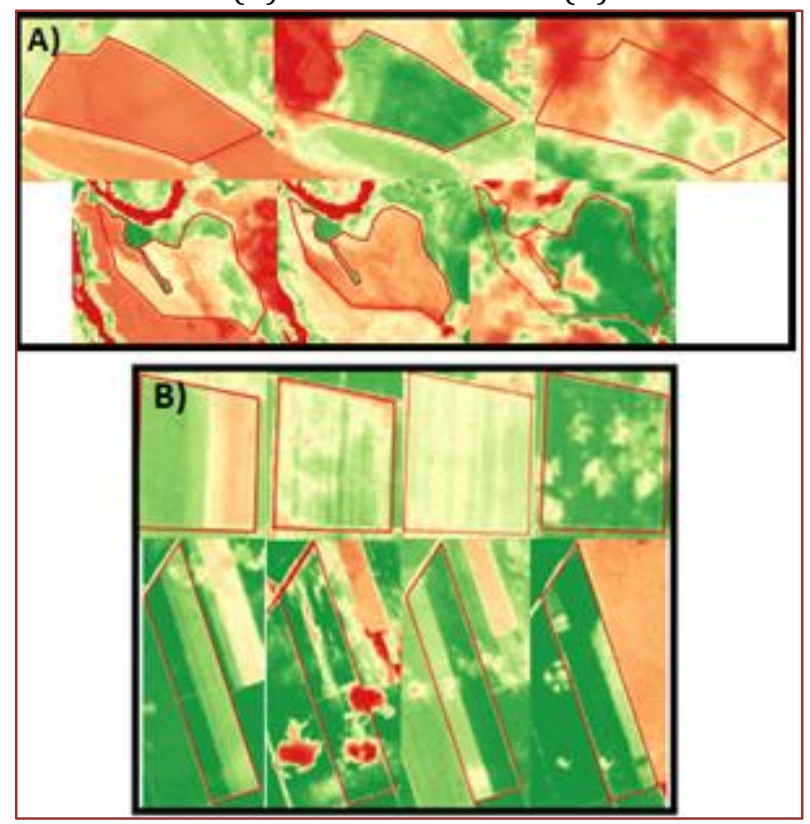

Contudo, ainda foi possível obter três mapas de NDVI para cada talhão, com ausência de nuvens ou qualquer tipo de interferência no manejo da área que impedisse de ser utilizada. Com esses mapas foram realizados a comparação de agrupamento entre os métodos classificação não supervisionada e supervisionada, neste último com classes de vigor definidas arbitrariamente.

Figura 5. Mapas de NDVI para os talhões de São Paulo.

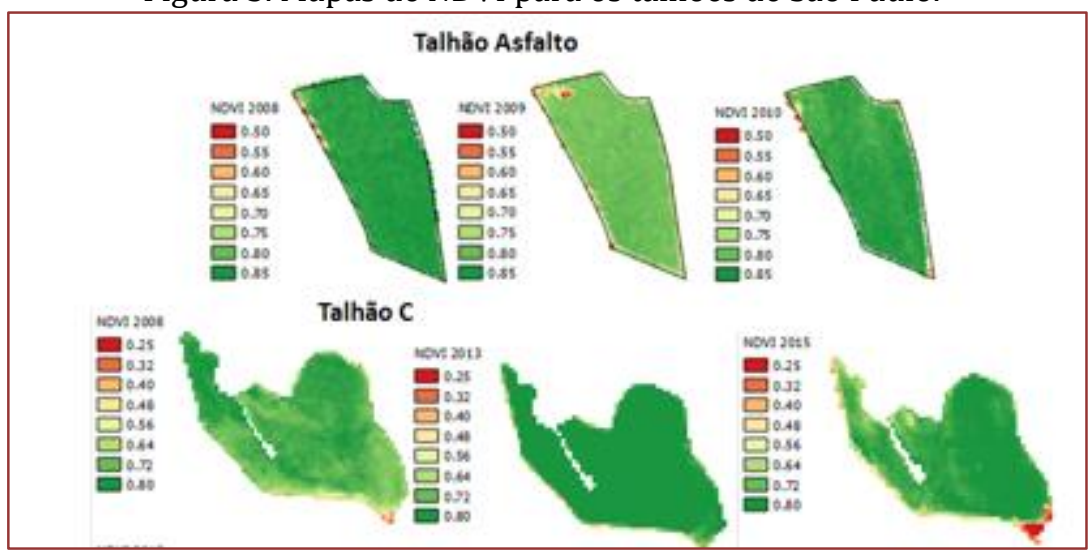

As Figuras 5 e 6 mostram os mapas de NDVI que foram utilizados para a análise de comparação das metodologias. 
Figura 6. Mapas de NDVI para os talhões da Bahia.

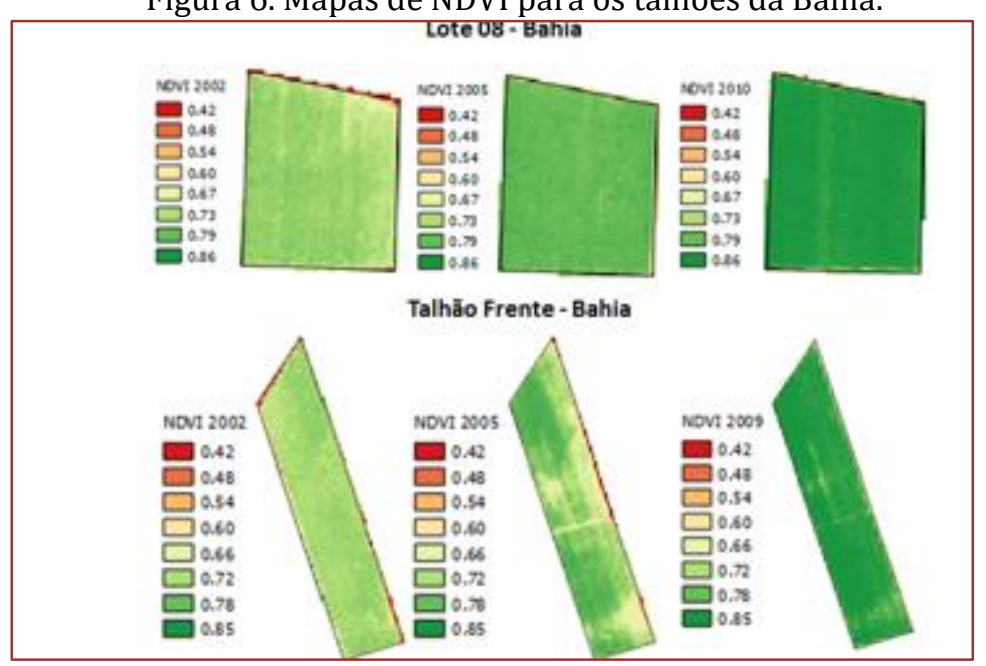

Na comparação entre a classificação pelos distintos métodos foram calculados o número de pixels obtidos pelo método não supervisionado dentro de cada classe definida no método supervisionado. Os valores são apresentados nas Tabelas 5 a 8.

Tabela 5. Número e percentual de pixels classificados pelo método não supervisionado dentro de cada classe obtida pelo método supervisionado no Talhão Frente, município de Luís Eduardo de Magalhães -

BA.

\begin{tabular}{|l|c|c|c|c|}
\hline \multicolumn{1}{|c}{ Classes vigor } & Cluster 1 & Cluster 2 & Cluster 3 & Cluster 4 \\
\hline Instável & $70(3 \%)$ & $62(2 \%)$ & $191(8 \%)$ & $0(0 \%)$ \\
\hline Maior vigor & $0(0 \%)$ & $28(1 \%)$ & $0(0 \%)$ & $854(34 \%)$ \\
\hline Vigor Intermediário & $18(1 \%)$ & $981(39 \%)$ & $65(3 \%)$ & $257(10 \%)$ \\
\hline Menor vigor & $1(0 \%)$ & $0(0 \%)$ & $6(0 \%)$ & $0(0 \%)$ \\
\hline
\end{tabular}

Nas Tabelas 5 e 6 das áreas da Bahia, para o Talhão Frente, nota-se boa classificação simultânea entre as duas metodologias, sendo possível relacionar em pares um cluster para uma classe de vigor. Para o Talhão 8, mais de um cluster teve grande percentagem de pixels classificados simultaneamente com uma única classe de vigor, resultado de maior instabilidade dos dados de vigor das plantas para esse talhão. 0 método não supervisionado demonstrou maior capacidade em demonstrar diferenças que o método supervisionado, que possui intervalos de classes definido arbitrariamente. Os Talhões Asfalto e C não tiveram boa correlação entre métodos, sendo classificado mais de um cluster para uma mesma classe de vigor.

Tabela 6. Número e percentual de pixels classificados pelo método não supervisionado dentro de cada classe obtida pelo método supervisionado para o Talhão 8, município de Luís Eduardo de Magalhães - BA.

\begin{tabular}{|l|c|c|c|c|}
\multicolumn{1}{|c}{ Classes de vigor } & Cluster 1 & Cluster 2 & Cluster 3 & Cluster 4 \\
\hline Ínstável & $41(3 \%)$ & $1(0 \%)$ & $7(0 \%)$ & $52(4 \%)$ \\
\hline Maior Vigor & $0(0 \%)$ & $231(16 \%)$ & $0(0 \%)$ & $1(0 \%)$ \\
\hline Vigor intermediário & $5(0 \%)$ & $736(51 \%)$ & $1(0 \%)$ & $339(24 \%)$ \\
\hline Menor Vigor & $24(2 \%)$ & $0(0 \%)$ & $0(0 \%)$ & $0(0 \%)$ \\
\hline
\end{tabular}

Tabela 7. Número e percentual de pixels classificados pelo método não supervisionado dentro de cada classe obtida pelo método supervisionado para o Talhão Asfalto, município de Itararé- SP.

\begin{tabular}{|l|c|c|c|c|}
\hline \multicolumn{1}{|c|}{ Classes de vigor } & Cluster 1 & Cluster 2 & Cluster 3 & Cluster 4 \\
\hline Ínstável & $29(3 \%)$ & $8(1 \%)$ & $17(2 \%)$ & $0(0 \%)$ \\
\hline Maior Vigor & $0(0 \%)$ & $0(0 \%)$ & $0(0 \%)$ & $349(38 \%)$ \\
\hline Vigor intermediário & $8(1 \%)$ & $0(0 \%)$ & $252(28 \%)$ & $245(27 \%)$ \\
\hline Menor Vigor & $0(0 \%)$ & $2(0 \%)$ & $0(0 \%)$ & $0(0 \%)$ \\
\hline
\end{tabular}


Tabela 8. Número e percentual de pixels classificados pelo método não supervisionado dentro de cada classe obtida pelo método supervisionado para o Talhão C, município de Itararé - SP.

\begin{tabular}{|l|c|c|c|c|}
\multicolumn{1}{|c}{ Classes de vigor } & Cluster 1 & Cluster 2 & Cluster 3 & Cluster 4 \\
\hline Ínstável & $6(1 \%)$ & $111(9 \%)$ & $155(13 \%)$ & $7(1 \%)$ \\
\hline Maior Vigor & $159(13 \%)$ & $0(0 \%)$ & $1(0 \%)$ & $185(16 \%)$ \\
\hline Vigor intermediário & $242(20 \%)$ & $2(0 \%)$ & $111(9 \%)$ & $206(17 \%)$ \\
\hline Menor Vigor & $0(0 \%)$ & $6(1 \%)$ & $0(0 \%)$ & $0(0 \%)$ \\
\hline
\end{tabular}

Para cada área foram obtidos números ótimos de clusters ou grupos que definissem a variabilidade espacial dos dados de vigor de plantas. As figuras que seguem representam os gráficos dos valores de índices FPI e MPE indicadores do número ótimo de clusters ou agrupamento para os dados NDVI.

Figura 7. Gráfico dos valores de índices FPI e MPE em função do número de classes na área do Talhão 8 BA.

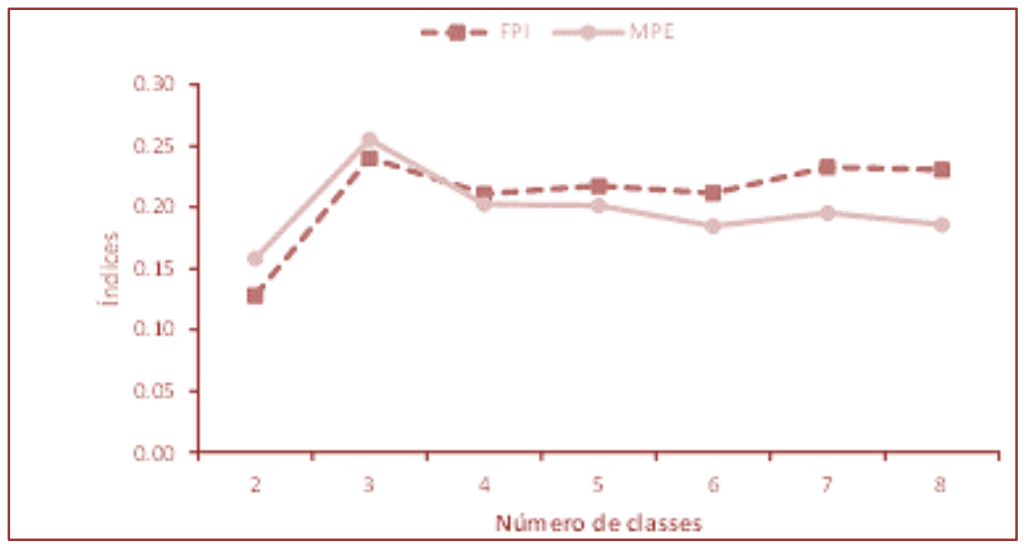

Figura 8. Gráfico dos valores de índices FPI e MPE em função do número de classes na área do Talhão Frente - BA.

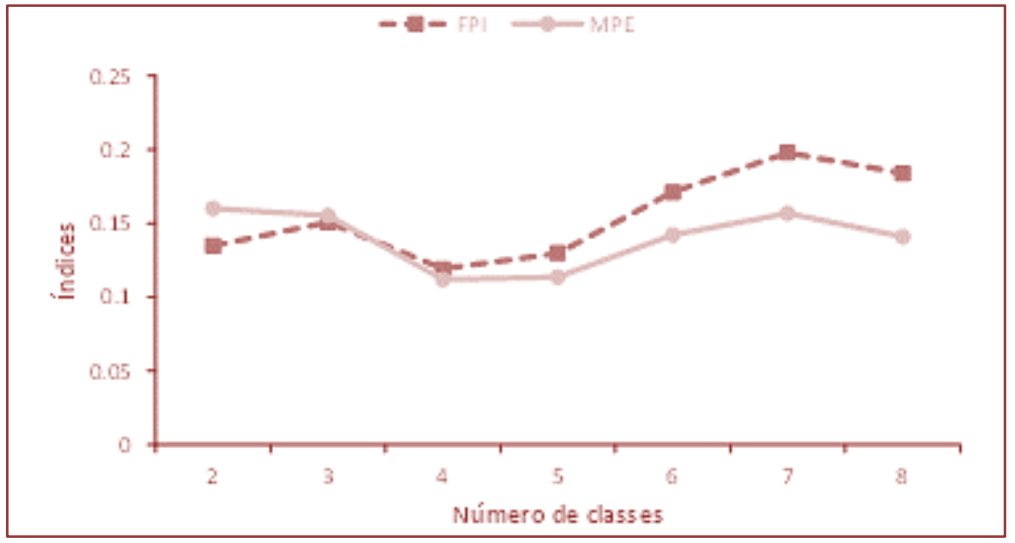

Para as áreas da Bahia, no Talhão 8 e Talhão Frente, ilustrados nas Figuras 7 e 8 foram definidos como número ótimo de clusters ou unidade de gerenciamento 2 e 4 respectivamente. 
Figura 9. Gráfico dos valores de índices FPI e MPE em função do número de classes na área do Talhão C SP.

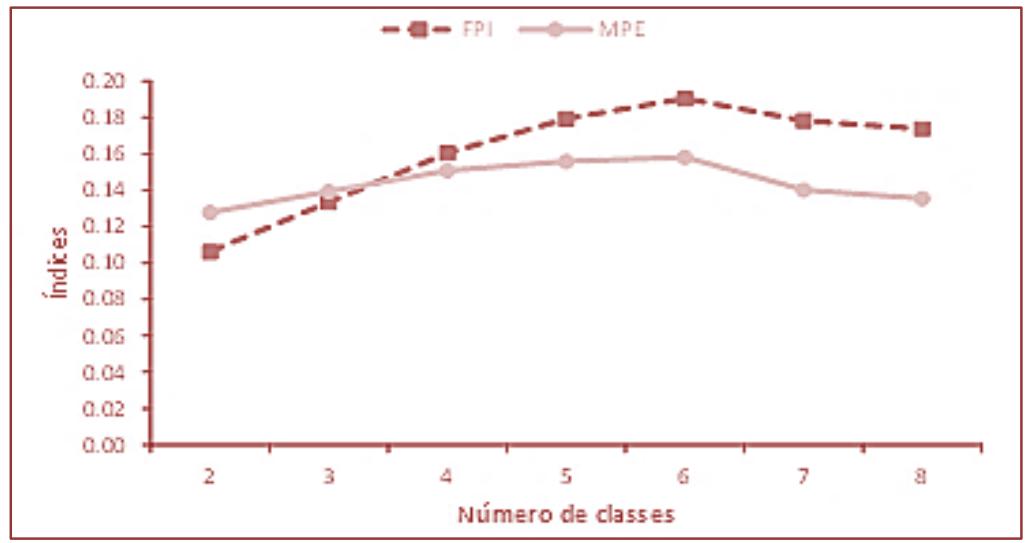

Figura 10. Gráfico dos valores de índices FPI e MPE em função do número de classes na área do Talhão Asfalto - SP.

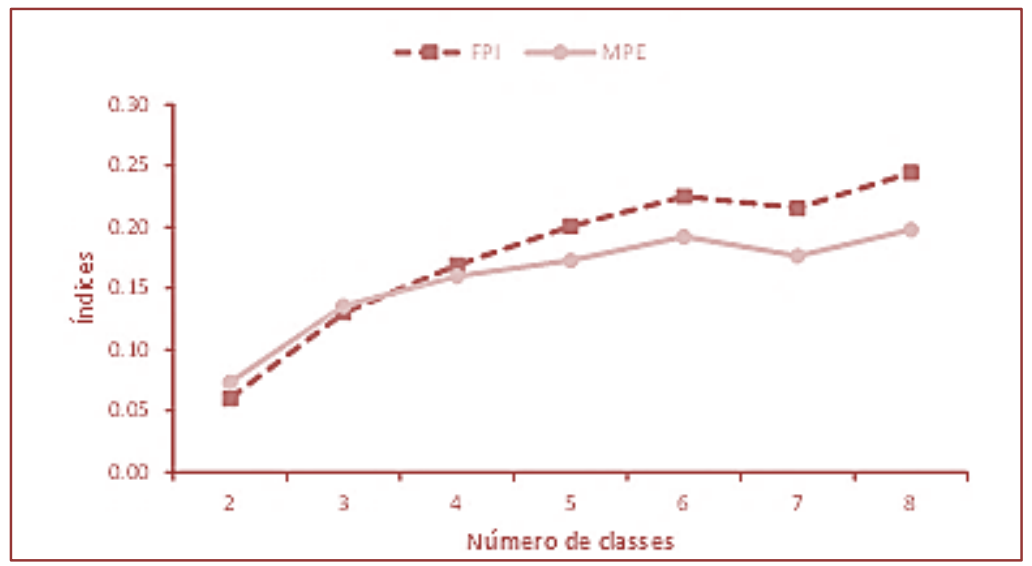

Para as áreas de São Paulo, nos Talhões C e Asfalto, representados pelas Figuras 9 e 10, foi definido o número ótimo 2 de clusters para as duas áreas. Fica evidenciado que são necessárias novas classificações para áreas distintas, pois o número de cluster ótimos diferiu entre áreas.

\section{REFERÊNCIAS}

[1] Castro, C. N. Definição de unidades do solo por meio da sua condutividade elétrica e variáveis físico-químicas. 2004. 131p. Dissertação (Mestrado em Engenharia e Sistemas Agrícolas) - Escola Superior de Agricultura "Luiz de Queiroz", Universidade de São Paulo, Piracicaba, 2004.

[2] Dainese, R. C.; Moreira, M. A.; Molin, J. P. Imagens landsat para mapeamento de variabilidade de produtividade de soja e milho em agricultura de precisão. In: Congresso Brasileiro de Agricultura de Precisão ConBAP, 2006. Anais... São Pedro - SP, 2006.

[3] Diker, K; Heermann, D. F. e Brodahl, M. K. Frequency Analysis of Yield for Delineating Yield Response Zones. Precision Agriculture, v. 5, p 435-444, 2004.

[4] Fridgen, J. J.; Kitchen, N. R.; Sudduth, K. A. Drummond, S. T.; Wiebold, J.; Fraisse, C. W. Management zone analyst (MZA): software for subfield management zone delineation. Agronomy Journal, v. 96, p. 100-108, 2004.

[5] Gomes, F. P. Curso de estatística experimental. 14a ed. Piracicaba, Degaspari. 477p.

[6] Grifo, A.\& Silva, J. M. Análise espacial e temporal da produção de milho. Revista da Unidade de Investigação do Instituto Politécnico de Santarém (Uiips), v. 2, p. 48-65, 2013. 
[7] Machado, H. M.; et al. Estudo da variação de parâmetros atmosféricos necessários para correção atmosférica de imagens de satélite. In: Simpósio Brasileiro Sensoriamento Remoto, 11, 2003, Belo Horizonte. Anais XI SBSR, Belo Horizonte: Inpe. p. 2537 - 2539, 2003.

[8] Minasny, B.; Macbratney, A. B. FuzMe version 2.1. Australian Centre for Precision Agriculture, The University the Sydney. 2002. http://www.usyd.edu.au/su/agri/acpa.

[9] Motta, J. L. G.; Fontana, D. C.; Weber, E. Evolução temporal do Ndvi/Noaa em área cobertas por pixels com proporções variáveis de soja. Revista Brasileira de Agrometeorologia, Santa Maria, v. 11, n. 2, p. 353 - 369, 2003.

[10] Schepers, A. R.; Shanahan, J. F.; Liebig, M. A.; Schepers, J. S.; Johnson, S. H.; Luchiari, A. Appropriateness of management zones for characterizing spatial variability of soil properties and irrigated corn yields across years. Agronomy Journal, v. 96, n. 1, p. 195-203, 2005.

[11] Ponzoni, F.J.; Shimabukuro, Y.E. Sensoriamento Remoto no Estudo da Vegetação. São José dos Campos, SP. Editor Parêntese, 144p. 2007.

[12] Rouse, J. W; HAAS, R. H.; Schell, J. A. Deering, D.W. Monitoring vegetation systems in the great plains with Erts, In: Earth Resources Technology Satellite -1 Symposium 3, 1973. Proceedings. Washington, 1973, v.1, Sec. A, p. 309-317.

[13] Schwalbert, R. A.; Amado, T. J. C.; Gebert, F. H.; Santi, A. L.; Tabaldi, F. Zonas de Manejo: atributos de e planta visando a sua delimitação e aplicação na agricultura de precisão. Revista Plantio Direto, ed. 140 , 2014.

[14] Shiratsuchi, L. S.; Brandão, Z. N.; Vivente, L; E.; Victoria, D. C.; Ducati, J. R.; Oliveira, R. P.; Vilela, M. F. Sensoriamento Remoto: Conceitos básicos e aplicações na Agricultura de Precisão. In: Agricultura de precisão: resultados de um novo olhar. 1. ed. Brasília: Embrapa, 2014. p. 58 - 73.

[15] Schowengerdt, R. A. Remote Sensing:models and methods for image processing. V.3. London: Academic Press, 522p., 2006.

[16] Thenkabail, P. S. Biophysical and yield information for precision farming from near-real-time and historical Landsat TM images. International Journal of Remote Sensing, v.24, n.14, p.2879-2904, 2003.

[17] United States Geological Survey (Usgs). Landsat Project Description. Disponível em: <http://landsat.usgs.gov/about_project_descriptions.php> Acesso em: 31 mar. 2015. 


\section{Capítulo 11}

\section{Contribuições para metodologia de avaliação de imagens termográficas de equinos}

\section{Juliana Sarubbi}

Vitor Inácio Hoelscher

Saionara Pereira Xavier

Diego Henrique dos Santos

Gabriela Cavalheiro Croda

Resumo:

A termografia de infravermelho é uma ferramenta de mensuração da temperatura de superfície de determinado corpo, utilizada na medicina humana e veterinária. Trata-se de um exame por imagem não-invasivo, sem contato com a superfície corpórea e indolor. Com relação ao seu emprego em equinos, é uma técnica útil para auxílio ao diagnóstico de problemas locomotores, de doenças infecciosas e para acompanhamento de tratamentos. Encontra ainda aplicações na detecção de doping e práticas ilícitas, na compreensão da capacidade de termorregulação e em testes de reação vacinal (local e sistêmica), além de várias contribuições relacionadas à mensuração do estado de estresse. Está ainda presente em avaliações relacionadas a reprodução animal, em acompanhamento em provas e treinamentos, em ajustes para equipamentos e apetrechos usados para cavalos como selas, embocaduras ou ferramentas de equitação e doma. Ainda pode ser utilizada para colaborar com a eficácia de técnicas terapêuticas, tais como a acupuntura termoguiada ou a fisioterapia. Porém, em razão do mau uso da ferramenta, a termografia para uso em animais tem caído em descrédito. Dando suporte à estas lucubrações, a ciência anda a passos não tão largos quanto à difusão equivocada da técnica e sua difamação. Assim, este capítulo tem por objetivo levantar problemas práticos da utilização da termografia infravermelha, tanto a campo quanto em pesquisa, discutindo possíveis contribuições experimentais que podem ser realizadas para reverter este quadro apresentado.

Palavras-chave: Bem-estar animal, termorregulação de equinos, diagnóstico em equinos, temperatura superficial 


\section{INTRODUÇÃO}

A termografia de infravermelho é uma ferramenta de mensuração da temperatura de superfície de determinado corpo. Utilizada desde a Segunda Guerra Mundial para a detecção de inimigos, é hoje amplamente empregada na medicina humana e veterinária. Trata-se de um exame por imagem nãoinvasivo, sem contato com a superfície corpórea, indolor. Pode ser realizada em um animal individualmente ou de um grupo de animais, simultaneamente. A imagem gerada pela termografia digital por infravermelho possibilita a visualização da temperatura da superfície corporal, identificando aumento ou diminuição da temperatura em pontos ou áreas, auxiliando no diagnóstico da origem da variação de temperatura.

Com relação ao seu emprego em equinos, é uma técnica útil para auxílio ao diagnóstico de problemas locomotores, de doenças infecciosas e para acompanhamento de tratamentos. Encontra ainda aplicações na detecção de doping e práticas ilícitas, na compreensão da capacidade de termorregulação e em testes de reação vacinal (local e sistêmica). Está ainda presente em avaliações relacionadas a reprodução animal, em acompanhamento em provas e treinamentos, em ajustes para equipamentos e apetrechos usados para cavalos como selas, embocaduras ou ferramentas de equitação e doma. Ainda pode ser utilizada para colaborar com a eficácia de técnicas terapêuticas tais como a acupuntura termoguiada ou a fisioterapia. Avaliações específicas relacionadas ao bem-estar animal, como ocorre com a avaliação da temperatura da carúncula lacrimal, também são corriqueiras.

Porém, em razão do mau uso da técnica, a termografia para uso em animais tem caído em descrédito. Dando suporte à estas lucubrações, a ciência anda a passos não tão largos quanto à difusão equivocada da técnica. Assim, este capítulo tem o objetivo de levantar problemas práticos da utilização da termografia, tanto a campo quanto em pesquisa, discutindo possíveis contribuições experimentais que podem ser realizadas para reverter este quadro.

\section{A TERMOGRAFIA COMO FERRAMENTA PARA AVALIAÇÃO DO BEM-ESTAR ANIMAL}

Considerando o bem-estar como o estado no qual o animal tem suas necessidades físicas e mentais atendidas, saúde, ausência de dor e estresse, conforto térmico e manutenção da homeostasia são aspectos importantes a serem considerados. Em todos eles, a termografia infravermelha pode fazer sua colaboração como ferramenta de avaliação.

Segundo Graciano et al., (2012) novas ferramentas e técnicas têm sido introduzidas na produção animal para ajudar na tomada de decisões, tanto para a parte nutricional, reprodutiva e especialmente para promover a saúde/conforto do animal, podendo assim controlar de maneira mais eficaz as variáveis ambientais e fisiológicas. A termografia infravermelha é um exemplo de ferramenta que pode ser utilizada para estudos dessas variáveis com precisão.

A ampla aplicação das câmeras termográficas em animais e seus grandes benefícios e praticidade faz com que o interesse por essa biotecnologia venha aumentando e que seja utilizada cada vez mais na rotina dos profissionais de diversas áreas (CHACUR, 2017).

Segundo Stewart et al., (2005), a termografia infravermelha pode detectar alterações no fluxo sanguíneo periférico, podendo ser uma ferramenta útil para avaliar o estresse em animais. Knízková et al., (2007) citam que a câmera termográfica é capaz de detectar variações mínimas de temperatura com precisão. Bouzida et al. (2009) relata que a utilização da análise de termografia infravermelha torna possível a identificação de pontos de valores distintos de temperatura radiante e tem sido valiosa para o reconhecimento de eventos fisiológicos em animais.

A medida da temperatura superficial pode ser uma importante ferramenta para medir a temperatura corporal dos animais sem aumentar as condições de estresse (SARUBBI et al., 2010). A duração do estresse térmico pode ocasionar um fracasso no mecanismo fisiológico de termorregulação, numa tentativa de compensar os efeitos do estresse, podendo ocasionar desde decréscimo no ganho de peso, até a prostração e óbito. (BORGES et al., 2003)

Os animais utilizam a vasodilatação periférica, ou seja, o aumento do fluxo sanguíneo para a superfície corporal, como um processo para a manutenção da homeotermia, ocasionando aumento na temperatura da superfície animal (RIBEIRO et al., 2008). Esta vasodilatação facilita a troca de calor do animal com o meio ambiente por processos sensíveis e a eficácia deste depende do gradiente térmico entre o corpo do animal e a temperatura ambiente (McCUTCHEON E GEOR, 2008). 0 fluxo sanguíneo é a principal via para a transferência de calor por convecção, direcionando o calor produzido no músculo para a pele e sistema 
respiratório. A capacidade de modificar a irrigação dos diferentes órgãos, se ajustando a diferentes necessidades, faz do sistema cardiovascular o mais eficiente executor da termoregulação. Os ajustes termorregulatórios da circulação sanguínea são tão eficientes, que a estabilidade térmica em ambientes termoneutros pode ser mantida pelo balanço entre vasoconstrição e vasodilatação periférica (McCONAHGY, F.F. et al., 1996). Por esta razão, a termografia é uma aliada em estudos relacionados à homeostasia e à termorregulação.

Há ainda aplicações indiretas relacionadas ao estresse térmico. Medeiros et al (2010) com o uso de uma câmera termográfica Thermal Imager da marca Testo 880 avaliou a temperatura de superfície de estruturas de galpões de suínos criados em sistema "wean to finish" e observou diferença significativa para a temperatura superficial do forro e da parede dentro do galpão que separa as baias, nos diferentes tratamentos, constatando que a diferença de temperatura, nas diferentes regiões internas do galpão pode ter sido influenciada pela temperatura externa do ambiente, em volta do galpão, também pode ser devido aos diferentes horários avaliados e a alguns fatores externos. Souza et al. (2008), trabalhando com avaliação a adaptação de caprinos leiteiros e conforto térmico das instalações considerou que com a aplicação da técnica da termografia de infravermelho será possível fazer: o mapeamento da distribuição térmica das estruturas construtivas e dos animais; a caracterização das diferentes tipologias de instalações zootécnicas, quanto aos tipos de materiais, e o balanço térmico; a verificação da qualidade de trocas térmicas quanto às sombras disponíveis aos animais e a identificação das melhores raças e tipos zootécnicos leiteiros, com maior grau de adaptação às condições climáticas do semiárido. Desta forma, a termografia contribui com a avaliação indireta do conforto térmico.

A aferição da temperatura de superfície ajuda a compreender estes ajustes da circulação sanguínea. Em estudos envolvendo animais, a termografia apresenta diferentes aplicabilidades, como por exemplo, aspectos relacionados a saúde, termorregulação escrotal e infertilidade em touros, conforto térmico de bovinos e estimativa do peso corporal (NUNES, 2011).

Na prática, a termografia é muito utilizada como auxílio ao diagnóstico. Nogueira et al. (2013) apresentam que a ferramenta permitiu identificar diferenças de temperaturas entre as metades mamárias saudáveis ou com mastite subclínicas daquelas com mastite clínica em estágio crônico de ovelhas e em diversas outras espécies.

\section{APLICAÇÕES DA TERMOGRAFIA EM EQUINOS}

Oliveira Filho et al. (2012), administrando $10 \mathrm{ml}$ de FCA (adjuvante Completo de Freund) no músculo serratus cervicis de equinos, concluiu que o exame termográfico foi eficaz e seguro na detecção da inflamação local. Nos casos de lombalgias, a termografia possui sua maior utilidade no mapeamento das possíveis lesões presentes na região toraco lombar (ALVES et al., 2007).

Como detecta o status fisiológico da região examinada, a termografia é útil na verificação do significado clínico de lesões encontradas no exame radiográfico e ultra-sonográfico (ALVES et al., 2007). Em razão da frequência de lesões musculoesqueléticas essa técnica é de suma importância para um possível diagnóstico antes que o animal desenvolva complicações anatômicas.

Em equinos atletas com alta exigência de desempenho, a termografia pode incrementar o treinamento destes animais, avaliando-se as injúrias musculoesqueléticas originadas de uma rotina de exercícios intensa, esta técnica pode prove informações úteis ao médico veterinário e treinadores para a preparação dos animais para competições (FIGUEIREDO et al., 2012).

Figueiredo et al. (2012) demonstraram através do relato de quatro casos clínicos de afecções locomotoras distintas que a termografia beneficiou no diagnóstico clínico de claudicações. Os sinais clínicos observados nos equinos com afecções locomotoras nem sempre são evidentes, podendo não se observar a claudicação ou alteração visível. Os autores sugeriram também o emprego do exame termográfico demonstrando sua eficácia para detecção de abscesso solar pela presença de calor proeminente principalmente quando se compara o membro com a afecção ao membro sadio.

Neste contexto, o exame termográfico permite a diferenciação de lesões e das regiões envolvidas, pelas alterações de temperatura demonstradas.

Os principais benefícios da termografia infravermelha em equinos estão relacionados aos seguintes fatos:

- Não ser um exame radioativo ou invasivo 
- Colaborar com a eleição da técnica a ser utilizada para o diagnóstico definitivo (radiografia ou ultrassonografia, por exemplo),

- Tornar possível a localização exata da lesão com a intenção de direcionar as outras técnicas de diagnóstico quando o exame físico gera dúvidas (por exemplo: onde devo radiografar? Em posição mais proximal ou mais distal?).

\section{CONSIDERAÇÕES PRÁTICAS SOBRE O DESCRÉDITO DA TERMOGRAFIA EM EQUINOS A CAMPO}

É importante ressaltar, portanto, que se trata de uma técnica de auxílio ao diagnóstico e que possui suas limitações, tais como: nem sempre consegue localizar lesões profundas, nem sempre localiza lesões crônicas, possui alto custo e sofre bastante com influências externas

Interessante é considerar que a termografia é uma técnica utilizada amplamente por engenheiros, e que vem sendo introduzida na rotina de Médicos Veterinários e Zootecnistas. Assim, é inevitável que muitas dúvidas surjam a respeito da técnica para ambos os lados.

Na prática, muitos equívocos têm sido cometidos. Um deles é a utilização dos termógrafos não adequados para a prática. Há profissionais "diagnosticando" com termovisores de smartphones, o que certamente interfere nos resultados e contribui para a banalização da técnica. A precisão do equipamento é fundamental para a aplicação correta da técnica. Em nossa prática de campo, temos percebido que resoluções menores que para 76,800 pixels (320 x 240) dificultam um bom trabalho.

No que tange aos procedimentos de captura das imagens, há bastante variação de acordo com a marca e o modelo do termógrafo. Há termógrafos, por exemplo, que recomendam ajustes para a captura das imagens de acordo com as faixas de temperatura do ambiente. Mas nem todos fazem estas recomendações.

Alguns termógrafos não possuem ajuste automático de foco, o que pode prejudicar a qualidade da imagem. Outros não determinam a distância adequada do termovisor até o objeto. É certo que tudo isso é calculável e há vários embasamentos físicos há para estes cálculos. Porém, dificilmente o aplicador Médico Veterinário ou Zootecnista fará estes ajustes sem orientação. Recomenda-se, portanto, termografar sempre à mesma distância.

Na teoria, os programas computacionais dos termógrafos deveriam, ao serem inseridos os dados de temperatura e umidade relativa do ar, fazerem ajustes. Porém é importante salientar que em alguns casos, essa inserção de dados não provoca alteração na temperatura superficial obtida pela imagem termográfica. Portanto, o aplicador deve estar atento. Para colaborar neste sentido, há metodologias que propõem a possibilidade da termografia em diferentes condições de temperatura. Uma metodologia interessante é a proposta por Basile (2012). 0 método Pad Temp corrige a temperatura obtida pela câmera por meio do procedimento que segue descrito. A temperatura ambiente da primeira avaliação (Tamb0) será o denominador de todas as equações de cálculo de $\theta i$ subsequentes. Durante as avaliações posteriores, deve ser coletada a temperatura ambiente do local (Tambi), valores os quais serão os numeradores da equação de $\theta$ i. Utiliza-se então a equação:

$$
\theta i=\frac{\text { Tambi }}{\text { Tamb0 }}
$$

Onde: Tamb0 - Temperatura ambiente no primeiro dia de avaliação, em Kelvin e Tambi - Temperatura ambiente em cada um dos dias subsequentes, em Kelvin.

Em seguida, realiza-se a padronização da temperatura da lesão dos dias subsequentes, dividindo-se a temperatura lida da lesão (ou local de avaliação)pelo valor calculado de $\theta$ i.

$$
\text { Tlesãoicorr }=\frac{\text { Tlesão }}{\theta \mathrm{i}}
$$

Onde: Tlesãoi - Temperatura da lesão lida diretamente da termografia, em Kelvin e

Tlesãoi_corr - Temperatura corrigida resultante, em Kelvin. 
Em análises comparadas, recomenda-se realizá-las sempre no mesmo horário, minimizando as alterações orgânicas circadianas que possam ocorrer.

Ainda é importante aplicar a técnica em locais livres de correntes de vento, sombras ou umidade. Em análises comparadas ainda ressalta-se a importância da fonte luminosa no local de captura da imagem. Em suínos, há descrições da influência da fonte luminosa na temperatura superficial de pele obtida pela termografia infravermelha (SANTOS et al., 2019).

Basile (2012) recomenda que não sejam aplicadas pomadas e que o último banho do animal deve ter ocorrido $12 \mathrm{~h}$ antes da realização do exame termográfico. 0 animal deve ser limpo com rasqueadeira, escova ou limpador de casco 60 minutos antes do exame. Umidade, sujidades, áreas sem pelos ou tricotomizadas podem interferir nas análises.

Um outro problema corriqueiro é a pouca literatura que padroniza as temperaturas normais dos animais termografados. Em geral, são comparados membros ou estruturas contralaterais e, clinicamente, $1^{\circ} \mathrm{C}$ de diferença entre os membros é considerado significativo. No entanto, diagnósticos de problemas que aumentam a temperatura dos dois membros ou dos quatro membros, por exemplo, como aconteceria em um quadro de laminite nos quatro membros, dificultaria o diagnóstico. 0 grupo de pesquisas do Laboratório de Ambiência e Bem-Estar Animal da UFSM tem realizado estudos para padronizar estas temperaturas em diferentes condições de ambiente, para diferentes raças, idade e pelagens de equinos, por meio do projeto $\mathrm{CNPq}$ - Contribuições para o uso da termografia infravermelha como ferramenta para a avaliação do bem-estar de equinos e suínos.

Outra consideração de aplicação prática é a de que no momento da análises das imagens é necessário alterar a emissividade do programa computacional. Para materiais biológicos, a emissividade considerada na literatura é de 0,95 a 0,98 . Para esta questão, sugerem-se estudos específicos para equinos, visto que a temperatura superficial de saída do software altera-se de acordo com a emissividade considerada, inclusive dentro desta faixa entre 0,95 e 0,98 .

A simplificação demasiada da análise termográfica parece ser um problema. Quando possível, analisar as imagens de diferentes formas, com diferentes paletas de cores, buscando melhores indicativos de locais onde a temperatura se diferencia. Às vezes é possível analisar estatisticamente médias da temperatura de diferentes pontos em um membro que nem sempre parecem diferentes quando se analisam poucos pontos "a olho". Inclusive, análises estatísticas podem colaborar de outras formas, como, por exemplo, os dados relativos aos desvios-padrões das áreas estudadas podem nos dar indícios de que devem ser procurados pontos mais específicos de aumento de temperatura da região estudada.

Ainda, transferir as imagens para o programa computacional do termógrafo é fundamental para evitar equívocos não visualizados no momento da captura da imagem.

\section{LUCUBRAÇõES SOBRE METODOLOGIA DE CAPTURA DE IMAGENS E ANÁLISE DAS IMAGENS TERMOGRÁFICAS}

Muitas ponderações podem ser realizadas no questionamento da técnica em questão. Por exemplo, fontes luminosas influenciam nos resultados da termografia? Índices climáticos ou fatores meteorológicos isolados influenciam na temperatura superficial de pele e de que forma as ferramentas disponíveis dariam suporte à estas influências? Cores de cascos ou pelagens diferentes merecem ponderações diferenciadas de análise?

Dando suporte às lucubrações, a ciência anda a passos não tão largos quanto à difusão equivocada da técnica. Alguns grupos de pesquisa vêm se empenhando neste sentido.

Um exemplo são os estudos que ponderam diferentes fontes de luminosidade. Considerando a hipótese de que o espectro luminoso emitido pela fonte de iluminação a qual o animal está submetido poderia interferir na detecção do infravermelho pelo termógrafo e que a temperatura superficial de suínos obtida por termografia é diferente em razão da fonte luminosa (SANTOS et al., 2019), acredita-se que a fonte luminosa interfira nos resultados da termografia de equinos.

Para suínos, os dados apresentados por Santos et al. (2019) mostraram diferenças nas temperaturas superficiais de imagens termográficas obtidas sob lâmpadas de LED e lâmpadas de vapor de mercúrio $(\mathrm{p}=0,003)$. Ambas as tecnologias apresentaram resultados iguais às lâmpadas fluorescentes. Sendo assim, quando se pretende comparar resultados, sugere-se termografar os animais sob fonte luminosa fluorescente. 
Porém, para equinos, dados preliminares da termografia do flanco de animais da raça crioula de diferentes pelagens os resultados, não obtiveram a mesma tendência quando comparadas as seguintes fontes luminosas: LED fria, LED quente, Fluorescente e sem fonte luminosa (escuro) (Tabela 1).

Tabela 1. Efeito de diferentes tipos de lâmpadas sobre a temperatura de superfície do flanco (TSF) de equinos da raça crioula.

\begin{tabular}{|c|c|}
\hline \multicolumn{2}{|c|}{ Tipo de Lâmpada } \\
\hline Escuro & $33,22(+2,13)$ \\
\hline Fluorescente fria & $33,27(+2,11)$ \\
\hline FL & $33,24(+2,08)$ \\
\hline LED & $33,29(+2,11)$ \\
\hline P. Valor & 0,99 \\
\hline
\end{tabular}

De acordo com estes dados, é possível obter que as fontes luminosas em questão (LED fria, LED quente, Fluorescente e escuro) não influenciaram na temperatura do flanco de equinos Crioulos de diferentes pelagens. Porém, acredita-se que mais estudos a este respeito devem ser realizados.

As imagens termográficas podem ser avaliadas de diferentes maneiras para verificar a temperatura média de uma região considerada. A maioria dos autores que trabalharam com imagens termográficas utilizaram-se da metodologia dos pontos aleatórios, procurando pontos de temperatura mais elevada, especialmente quando precisaram localizar pontos de inflamação em animais.

Porém, a avaliação da temperatura média da região é importante quando se trabalha com a termorregulação. A metodologia dos pontos aleatórios, que consiste em escolher pontos na área avaliada, de forma aleatória, não é a única possível de ser aplicada, segundo Chacur, (2017) apesar de já existir aplicação em vários modelos animais é de grande importância a atenção na padronização da análise dos termogramas para que os resultados sejam precisos e dessa forma, seja um parâmetro além de promissor, necessário e auxiliar.

O quadro 1 apresenta alguns trabalhos de termografia e suas metodologias para tratamento das imagens.

Quadro 1 - Metodologias empregadas na literatura para tratamento das imagens termográficas.

\begin{tabular}{|c|l|l|}
\hline \multicolumn{2}{|c|}{ Autor } & \multicolumn{2}{c|}{ Avaliação } & Metodologia Utilizada \\
\hline Oliveira Filho et al (2012) & $\begin{array}{l}\text { Inflamação induzida com administração } \\
\text { de FCA no músculo serratos cervicis. }\end{array}$ & $\begin{array}{l}\text { Análise da área em que a temperatura } \\
\text { encontrava-se diferente da } \\
\text { fisiologicamente esperada (Pontos } \\
\text { Aleatórios) }\end{array}$ \\
\hline Alves et al (2007) & Diagnóstico de Lombalgias. & $\begin{array}{l}\text { Análise da área em que a temperatura } \\
\text { encontrava-se diferente da } \\
\text { fisiologicamente esperada (Pontos } \\
\text { Aleatórios) }\end{array}$ \\
\hline Figueiredo et al(2012) & $\begin{array}{l}\text { Avaliação do boleto de equinos, avaliação } \\
\text { termográfica da palma dos casco, } \\
\text { avaliação da concentração de calor nos } \\
\text { membros posteriores na região peitoral, } \\
\text { avaliação de inflamação na coluna } \\
\text { vertebral. }\end{array}$ & $\begin{array}{l}\text { Análise da área em que a temperatura } \\
\text { encontrava-se diferente da } \\
\text { fisiologicamente esperada (Pontos } \\
\text { Aleatórios) }\end{array}$ \\
\hline Fantini (2010) & $\begin{array}{l}\text { Avaliação toracolombar em equídeos de } \\
\text { tração. }\end{array}$ & $\begin{array}{l}\text { Análise da área em que a temperatura } \\
\text { encontrava-se diferente da } \\
\text { fisiologicamente esperada (Pontos } \\
\text { Aleatórios) }\end{array}$ \\
\hline Autio et al (2006) & $\begin{array}{l}\text { Efeito da temperatura ambiente sobre a } \\
\text { perda de calor; efeito do tipo de cavalo } \\
\text { para perda de calor. }\end{array}$ & $\begin{array}{l}\text { Análise de imagem termográfica } \\
\text { através da delimitação de área }\end{array}$ \\
\hline
\end{tabular}


Quadro 1 - Metodologias empregadas na literatura para tratamento das imagens termográficas.

(continuação...)

\begin{tabular}{|c|c|c|}
\hline Autor & Avaliação & Metodologia Utilizada \\
\hline Sarubbi et al (2010) & $\begin{array}{l}\text { Avaliação da temperatura superficial de } \\
\text { leitões após vacinação com vacina } \\
\text { comercial. }\end{array}$ & $\begin{array}{l}\text { Delimitação de área: foi traçado um } \\
\text { polígono de modo a abranger as regiões } \\
\text { do pescoço, flanco (direito ou esquerdo, } \\
\text { por conveniência, evitando a contenção } \\
\text { dos animais) e pernis dos leitões. Desta } \\
\text { região foi extraída a média de } \\
\text { temperatura superficial (de pele) do } \\
\text { perfil esquerdo de cada leitão. }\end{array}$ \\
\hline Medeiros (2010) & $\begin{array}{l}\text { Avaliou a temperatura de superfície de } \\
\text { estruturas de galpões de suínos criados } \\
\text { em sistema "wean to finish" }\end{array}$ & $\begin{array}{l}\text { Análise de imagem termográfica } \\
\text { através da delimitação de área }\end{array}$ \\
\hline Souza (2015) & $\begin{array}{l}\text { Avaliou a temperatura de superfície da } \\
\text { bolsa escrotal de bovinos da raça nelore } \\
\text { afim de verificar se existe relação da } \\
\text { qualidade espermática com a } \\
\text { temperatura de superfície da bolsa } \\
\text { escrotal dos bovinos }\end{array}$ & $\begin{array}{l}\text { Análise feita através de pontos pré } \\
\text { determinados nos locais que os } \\
\text { pesquisadores julgaram mais } \\
\text { importantes anatomicamente. }\end{array}$ \\
\hline Da Silva (2017) & $\begin{array}{l}\text { Avaliou a adaptabilidade de caprinos } \\
\text { leiteiros com auxílio da precisão } \\
\text { termográfica nas condições ambientais } \\
\text { do semiárido brasileiro. }\end{array}$ & $\begin{array}{l}\text { Análise através de } 10 \text { regiões } \\
\text { delimitadas no corpo do animal por } \\
\text { meio de marcadores (focinho, olho, } \\
\text { pescoço, costado, tronco, garupa, coxa, } \\
\text { canela, flanco e ventre) - Delimitação de } \\
\text { área }\end{array}$ \\
\hline Faquin (2017) & $\begin{array}{l}\text { Avaliou a capacidade de dissipação da } \\
\text { temperatura do pé de um atleta por meio } \\
\text { do cabedal de um tênis de futsal }\end{array}$ & $\begin{array}{l}\text { Análise realizada através de dois pontos } \\
\text { pré determinados no tênis do atleta. }\end{array}$ \\
\hline
\end{tabular}

Todos os trabalhos citados no Quadro 1 apresentam somente um avaliador. Este fato reforça a teoria de que os autores acreditam não haver diferenças entre os resultados encontrados quando a análise é realizada por diferentes avaliadores.

Para tanto, o teste denominado Análise de metodologias utilizadas na avaliação de imagens termográficas de equinos propõe uma discussão sobre a possibilidade da repetibilidade da metodologia, bem como sobre formas de tratamento das imagens.

As imagens foram adquiridas em condição de campo, no Planalto Central do Rio Grande do Sul, com altitude de $180 \mathrm{~m}$ acima do nível do mar. As imagens termográficas foram capturadas com a temperatura ambiente média de $20^{\circ} \mathrm{C}(+1,1)$, na parte da manhã e $27,6^{\circ}(+1,5) \mathrm{C}$ na parte da tarde. A umidade relativa média do ar pela manhã foi de 71,4\%, e na parte da tarde de 58,8\%. Foram utilizadas 15 éguas da raça Crioula com idade entre 3 e 4 anos. Os dados foram submetidos à análise de variância ANOVA $(\mathrm{P}<0,05)$, através do programa estatístico Statgraphics plus®. Quatro imagens termográficas foram capturadas de cada animal estudado em dois períodos distintos manhã e tarde. Uma primeira imagem foi obtida antes do exercício e a segunda foi capturada logo após ser realizado exercício controlado por 15 minutos. 0 primeiro animal foi fotografado às $10 \mathrm{~h}$ e os outros subsequentemente. Na parte da tarde o procedimento foi repetido e a primeira imagem do primeiro cavalo foi obtida as $15 \mathrm{~h}$. Para a obtenção das imagens termográficas foi utilizada uma câmera Thermal Imager (Testo 870-1@) com variação de $\pm 0,1^{\circ} \mathrm{C}$ e

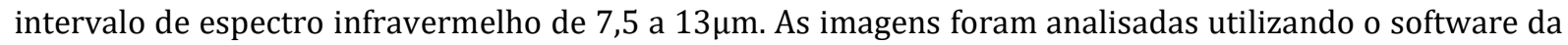
câmera (Testo IR soft Software), com a escala definida na opção paleta ferro com emissividade de 0,95. A temperatura de superfície (TS) foi calculada considerando uma área pré-determinada no flanco direito do animal com o intuito de abranger grande parte do animal, por meio de três métodos avaliativos, sendo eles: M1 - Consiste em obter a temperatura média da área circundada (figura 1a), M2 - Consiste obter a temperatura média de 17 pontos marcados de forma aleatória em forma de "X", na mesma área considerada para M1 do animal (figura 1b), M3 - Consiste em obter a temperatura média de 17 pontos marcados de forma aleatória, sem seguir padrão, na área pré-determinada em M1 (figura 1c). Para a M2 e 
M3 foram considerados 17 pontos pois foi possível observar que esta quantia de marcadores de temperatura abrangiam de forma satisfatória a área pré-determinada.

Figura 1. Ilustração das metodologias comparadas para a análise da temperatura superficial média do flanco de equinos.

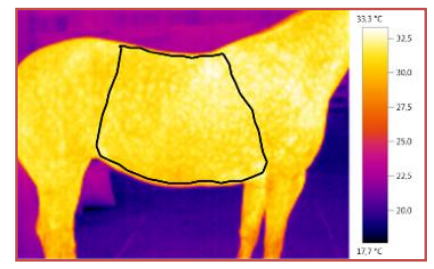

a) Exemplo da metodologia de delimitação da área em flanco direito de equino (M1).

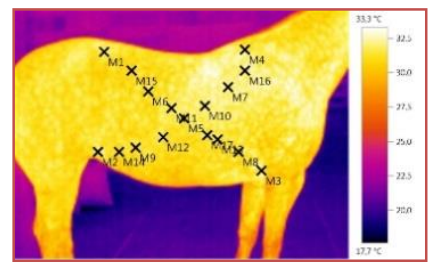

b) Exemplo de metodologia de pontos aleatórios em " $\mathrm{X}$ " em flanco direito de equino (M2).

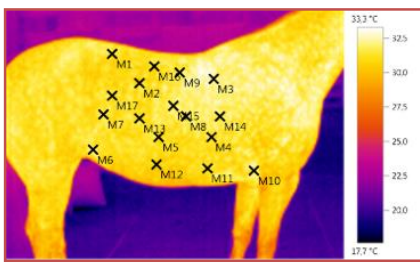

c) Exemplo de metodologia de pontos aleatórios sem padrão em flanco direito de equino (M3).

Com o intuito de avaliar a confiabilidade das metodologias empregadas e verificar a sua repetibilidade por outros avaliadores as imagens obtidas foram analisadas por três avaliadores, sendo eles: dois acadêmicos do curso de Zootecnia do Campus de Palmeira das Missões e o terceiro avaliador uma aluna do ensino médio, sendo que cada avaliador realizou a avaliação por meio das três metodologias propostas (3x3), importante ressaltar que todos os avaliadores receberam o mesmo treinamento.

Analisando os resultados gerados pode-se observar que não houve diferença estatística $(p<0,05)$ em relação as metodologias utilizadas para analisar as imagens. Também não ouve diferença significativa em relação a utilização de um ou mais avaliadores, tão pouco houve interação entre metodologias utilizadas em relação aos avaliadores utilizados neste experimento. Conforme tabela 2.

Tabela 2- Temperaturas Medias $\left({ }^{\circ} \mathrm{C}\right)$ encontradas nas análises de cada avaliador nas diferentes metodologias.

\begin{tabular}{|l|c|c|c|}
\hline \multicolumn{2}{|c|}{ Avaliador 1 } & Avaliador 2 & Avaliador 3 \\
\hline Pontos em X & 30,09 & 30,05 & 30,04 \\
\hline Área determinada & 29,94 & 30,06 & 30,08 \\
\hline Pontos aleatórios & 30,042 & 30,02 \\
\hline P-valor Metodologias & & 0,76 \\
\hline P-valor Avaliadores & & 0,73 \\
\hline $\begin{array}{l}\text { P-Valor Metodologias } x \\
\text { Avaliadores }\end{array}$ & & 0,99 \\
\hline
\end{tabular}

*Médias não significativas pela ANOVA $(\mathrm{P}<0,05)$.

Estes resultados obtidos neste estudo podem ser devido ao fato de todos os avaliadores terem recebido treinamento antes de analisarem as imagens. Assim, é importante ponderar o treinamento da equipe.

Este estudo concluiu que metodologias de pontos em X, pontos aleatórios e delimitação de área, podem ser utilizadas com eficácia e não apresentam diferença estatística entre si, fato este que reforça a ideia que indiferente da metodologia utilizada no tratamento das imagens, é possível obter dados confiáveis da temperatura de superfície dos equinos. 
Com relação à repetibilidade das metodologias aqui propostas conclui-se que a quantidade de avaliadores utilizados na análise das imagens termográficas não interferiu na qualidade e veracidade dos dados obtidos, podendo assim validar e corroborar com trabalhos já realizados por outros autores, os quais na ocasião usaram somente um avaliador.

\section{CONSIDERAÇÕES FINAIS}

0 uso da termografia infravermelha na espécie equina exige muito estudo e trocas de experiências entre profissionais usuários desta ferramenta, por se tratar de uma técnica difundida em diversas áreas, mas com aplicações relativamente recente em animais. Esta troca de informações aliada aos estudos científicos de suporte farão com que a ferramenta seja utilizada com a credibilidade e o respeito que ela merece por seus inúmeros benefícios à saúde e ao bem-estar dos animais.

\section{AGRADECIMENTOS}

A equipe de trabalho agradece ao Conselho Nacional de desenvolvimento Científico e Tecnológico - CNPq e ao Fundo de Incentivo à Pesquisa da UFSM que fomentaram este projeto.

\section{REFERÊNCIAS}

[1] ALVES, A. L. G. et al. Lombalgia em Eqüinos. Brazilian Journal Of Veterinary Research And Animal Science. São Paulo, p. 191-199. 07 fev. 2007.

[2] AUTIO, E. et al. Measuring the Heat Loss in Horses in Different Seasons by Infrared Thermography. Journal of Applied Animal Welfare Science. Kuopio, p. 211-221. ago. 2006.

[3] BASILE R.C. Metodologia de avaliação e análise de termografia em equinos. Universidade Estadual Paulista, Faculdade de Ciências Agrárias e Veterinárias- Campus Jaboticabal-SP, 2012: 13-91

[4] BOUZIDA, N.; BENDADA, A.; MALDAGUE, X.P. Visualization of body thermoregulation by infrared imaging. Journal of Thermal Biology, Oxford, v.34, n.3, p.120-126, 2009.

[5] BORGES, S.A.; MAIORKA, A.; SILVA, A.V.F. Fisiologia do estresse calórico e a utilização de eletrólitos em frangos de corte. Ciência Rural, Santa Maria, v. 33, n. 5, set-out, 2003.

[6] CHACUR, M.G.M. et al. Aplicações da termografia por infravermelho na reprodução animal e bem-estar em animais domésticos e silvestres. Revista Brasileira de Reprodução Animal, [S.l.], v. 40, n. 3, p. 88-94, may 2017. ISSN 1809-3000. Disponível em: <http://revistas.bvs-vet.org.br/rbra/article/view/37031/41623>. Acesso em: 25 jan. 2018.

[7] DA SILVA, E.M.N. et al. Avaliação da adaptabilidade de caprinos leiteiros com auxílio da precisão termográfica no semiárido brasileiro. Brazilian Journal of Veterinary Medicine, v. 36, n. 2, p. 231-237, 2017

[8] FAQUIN, A; DA FONSECA, F.F. Avaliação da dissipação de calor radiante em calçado de Futsal através de análise termográfica. Revista Brasileira de Futsal e Futebol, v. 9, n. 33, p. 138-143, 2017.

[9] FANTINI, P. Avaliação Toracolombar em Equideos de Tração: Estudo Clínico, Termográfico e Ultrassonográfico. 2010.125.f. Dissertação (Mestrado) Curso de Medicina veterinária, Universidade Federal de Minas Gerais, Minas Gerais, 2010

[10] FIGUEIREDO, T. et al. A Importância do Exame Termográfico na Avaliação do Aparato Locomotor em Eqüinos Atletas. Revista Científica Eletrônica de Medicina Veterinária, Garça, v. 18, n. 9, p.1-15, jan. 2012. Semestral.

[11] FREITAS, Eduardo Villela Villaça. Variáveis Fisiológicas em Equinos Submetidos a Dietas com Adição de Óleo Vegetal e a Exercício Físico de Longa Duração. 2007. 69 f. Tese (doutorado) - Universidade Estadual Paulista, Faculdade de Ciências Agrárias e Veterinárias, Jaboticabal, 2007,

[12] GRACIANO, DANIELA E. Aplicações da termografia infravermelha na produção animal. 2012. Dissertação (Mestrado) - Faculdade de Ciências Agrárias, Universidade Federal da Grande Dourados, 2012.

[13] KNÍŽKOVÁ, I.; KUNC, P.; GÜRDÍL, G.A.K.; PINAR, Y.; SELVÍ, K.Ç. Applications of infrared thermography in animal production. Journal of the Faculty of Agriculture, Kyushu, v.22, n.3, p.329-336, 2007

[14] McCUTCHEON, L. J.; GEOR, R. J. Chapter 6.3: Thermoregulation and exercise associated heat stress. First Edit ed. [s.l.] Elsevier Ltda, 2008. p. 382-396

[15] MEDEIROS, B.B.L. ; MASSARI, J.M. ; MAIA, A.P.A. ;SARUBBI, J.; MOURA, D. J. Termografia Infravermelha para avaliação da temperatura de superfície de estruturas de galpão de suínos criados em sistema. In: Paula, M.O. et al. 
(Org.). Construções Rurais E Ambientes Protegidos: Inovações Tecnológicas e Ambiência na Produção Animal Sustentável em Condições de Clima Quente. 1ed.Viçosa: UFV, 2012, v. , p. 364-368.

[16] NOGUEIRA, F. R. Botão et al. Termografia Infravermelha: Uma Ferramenta Para Auxiliar no Diagnóstico e Prognóstico de Mastite em Ovelha. Revista Brasileira de Medicina Veterinária, Sousa, v. 35, n. 3, p.289-297, set. 2013.

[17] NUNES, M. L. A. Bem-estar de Matrizes Suínas em Gestação: Estimativa da Condição de Conforto Térmico, Análise Comportamental e Produtiva no Alojamento Coletivo com Uso de Cama. 2011. 154 f. Tese (Doutorado) - Curso de Zootecnia, Universidade de São Paulo, Piracicaba, 2011.

[18] OLIVEIRA FILHO, J. P. DE. et al. Avaliação Termográfica em Equinos com Inflamação Experimental Induzida Pela Administração de Adjuvante Completo de Freund.2012. Disponível em: <http://www.itarget.com.br/newclients/abraveq2012/down/2012/59.pdf>. Acesso em: 11 jun. 2018.

[19] RIBEIRO, N.L. et al. Avaliação dos índices de conforto térmico, parâmetros fisiológicos e gradiente térmico de ovinos nativos. Revista de Engenharia Agrícola, Jaboticabal, v.28, n.4, p.614-623, 2008

[20] SANTOS, D.H., XAVIER, S.P., BORILLE, R., SARUBBI, S. Temperatura superficial de leitões por meio de termografia em diferentes condições de luminosidade. In: 34a Jornada Acadêmica Integrada. 2019.

[21] SARUBBI J.; BORDIN E. L; OLIVEIRA F.; DELVECCHIO A.; JOISEL F. Safety evaluation of Sprintvac® by measure of piglet's body temperature in a commercial farm in Brazil. In: International Pig Veterinary Society (IPVS) Congress, 21, 2010, Vancouver. Proceedings. Vancouver: IPVS, 2010. 1 CD-ROM

[22] SOUZA, Camila Dutra de et al. Termografia digital por infravermelho no estudo de características reprodutivas de touros nelore (Bos taurus indicus). Dissertação (Mestrado) - Universidade do Oeste Paulista. 2015.

[23] SOUZA, B. B.; SOUZA, E. D.; CEZAR, M. F. et al. Temperatura superficial e índice de tolerância ao calor de caprinos de diferentes grupos raciais no semi-árido nordestino. Ciência e Agrotecnologia. v.32, n.1, p.275-280,2008

[24] STEWART, M. et al. Infrared thermography as a non-invasive tool to study animal welfare. Animal Welfare, v. 14, n. 4 , p. $319-325,2005$. 


\section{Capitulo 12}

\section{Desenvolvimento do protótipo de uma semeadora conservacionista para agricultura familiar}

\section{Rafaela Paula Melo \\ Daniel Albiero \\ Max César de Araújo \\ Iury Alberto Mota de Lima \\ Luís Gustavo Chaves da Silva}

Resumo: Os agricultores familiares do semiárido cearense convivem com uma situação peculiar no que se refere aos níveis de tecnologias adotadas no sistema de produção. Portanto, é necessário realizar a inclusão de tecnologias que contribuam com a elevação da qualidade do trabalho agrícola familiar. 0 objetivo do trabalho foi desenvolver um protótipo de uma semeadora puncionadora para a agricultura familiar e avaliar a distribuição de sementes do mesmo. Utilizou-se a análise de sistemas técnicos conhecidos e a função síntese para desenvolver a concepção do protótipo. Os desenhos detalhados do protótipo foram feitos por meio do software Solid Edge ST6 ${ }^{\circledR}$ e o Autodesk Fusion $360{ }^{\circledR}$. Os espaçamentos da distribuição longitudinal de sementes foram classificados como duplos, aceitáveis ou falhos. 0 ensaio de simulação de tensão permitiu a percepção dos pontos críticos do projeto e a análise de tensão do protótipo auxiliou de forma significativa, pois forneceu informações relevantes que foram levadas em consideração para realizar melhorias na estrutura do protótipo. 0 protótipo da semeadora puncionadora obteve ótimo índice de distribuição de sementes, pois na distribuição longitudinal de sementes obteve 94,28 \% de espaçamentos aceitáveis.

Palavras-Chave: Distribuição de Semente, Punção, Projeto de Máquinas. 


\section{INTRODUÇÃO}

Os equipamentos disponíveis para os agricultores familiares, em sua maioria, possuem problemas relacionados ao custo de aquisição, inadequação ou a falta de equipamentos para as condições da agricultura familiar, além de apresentarem baixa qualidade de operação (MELO, 2017).

Portanto, faz-se necessário o desenvolvimento de máquinas e equipamentos voltados para agricultura familiar, utilizando-se tecnologias que possam contribuir com a elevação da qualidade do trabalho e produtividade (ALBIERO, 2010).

Os solos cearenses em geral são pouco profundos o que contribui para que os mesmos sejam suscetíveis a processos erosivos, sendo assim há uma preocupação em relação à utilização de práticas conservacionistas aliadas ao uso de máquinas adaptadas às condições destes solos (LIMA et al., 2002).

Desta forma, o uso de tecnologias que busque um modelo de produção agrícola onde prevaleça a conservação apresenta-se como uma solução viável para as regiões semiáridas, sendo assim as semeadoras que possuem sistema puncionador podem ser uma alternativa para agricultura familiar cearense, pois possibilitam o menor revolvimento do solo. Estas semeadoras semeiam de forma pontual o que aumenta a possibilidade de elevar à produtividade de culturas sensíveis a uniformidade de distribuição entre plantas, além de promover maior precisão no posicionamento das sementes no solo e menor revolvimento solo o que diminui os processos erosivos (TEXEIRA, 2008).

Diante do exposto, buscou-se desenvolver um protótipo de uma semeadora puncionadora para a agricultura familiar e avaliar a distribuição de sementes do mesmo.

\section{MATERIAL E MÉTODOS}

Para a elaboração da concepção do protótipo foi utilizada a análise de sistemas técnicos conhecidos para encontrar soluções como ponto de partida para novas variantes conforme as recomendações de Pahl et al., (2005).

A função síntese também foi utilizada como método para o desenvolvimento do protótipo da semeadora. 0 software Autodesk Fusion $360^{\circledR}$ foi utilizado para a elaboração para realizar análise de tensões e deformações do protótipo pelo método dos elementos finitos.

Para realizar o estudo da simulação de tensões foi definido todas as propriedades dos materiais utilizados na construção do protótipo. As principais características dos materiais empregados para realizar a simulação foram: coeficiente de Poisson de 0,28; densidade do material de $7.833 \mathrm{~kg} \mathrm{~m}^{-3}$, módulo de elasticidade de $206.800 \mathrm{MPa}$; tensão de escoamento de $393 \mathrm{MPa}$ e tensão de ruptura de $469 \mathrm{MPa}$.

Para a simulação das tensões que atuam no protótipo o software foi alimentado com os seguintes valores: força de atrito em cada pneu de $3.271,51 \mathrm{~N}$ e a força que atua no sistema puncionador foi de 89,15 $\mathrm{N}$. Todas as possibilidades de forças que poderiam atuar sobre o protótipo foram levadas em consideração, e para verificar as forças que atuam no sistema puncionador considerou-se a o valor máximo de tensão de $0,5 \mathrm{MPa}$ em todos os gráficos gerados.

Foi utilizada a metodologia recomendada por Kurachi et al., (1989) para a avaliação dos espaçamentos entre sementes. Por meio desta metodologia os espaçamentos coletados da distribuição longitudinal de sementes foram avaliados e classificados como duplos, aceitáveis ou falhos. 0 protótipo da semeadora foi regulado para depositar de 6 a 7 sementes por metro e para obter profundidade de $50 \mathrm{~mm}$.

\section{RESULTADOS E DISCUSSÃO}

Observa-se na Figura 1 os valores de tensão que levam o material a falhar, constata-se que em nenhuma região da estrutura as tensões excedem o limite do material de $588 \mathrm{MPa}$, no entanto verifica-se que alguns pontos da barra de tração e do eixo cames já estão sofrendo stress a partir da tensão de $125 \mathrm{MPa}$, deste modo o material já começa a sofrer deformações. 
FIGURA 1. Análise de tensões no chassi do protótipo da semeadora puncionadora.

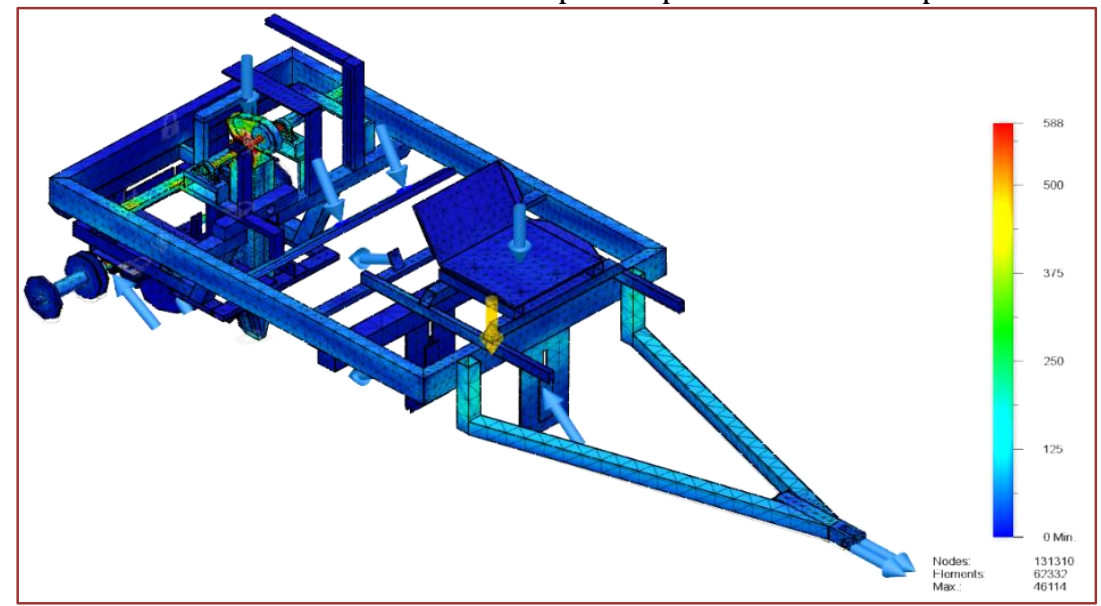

A Figura 2 apresenta a análise de tensões no puncionador, verifica-se que algumas zonas do puncionador excedem o limite do material de $588 \mathrm{MPa}$, sendo assim, observa-se que o puncionador começa a sofrer deformação a partir de $262 \mathrm{MPa}$, nota-se que existem 3 pontos críticos no sistema, ou seja, 3 pontos que apresentam risco eminente de ruptura, este fato é decorrente de estarem localizados nas áreas onde as forças envolvidas para acionar o puncionador atuam diretamente. Os pontos que se encontram mais suscetíveis à ruptura são a zonas de contato entre o mecanismo puncionador e o cames.

FIGURA 2. Análise de tensões do sistema puncionador para deposição de sementes.

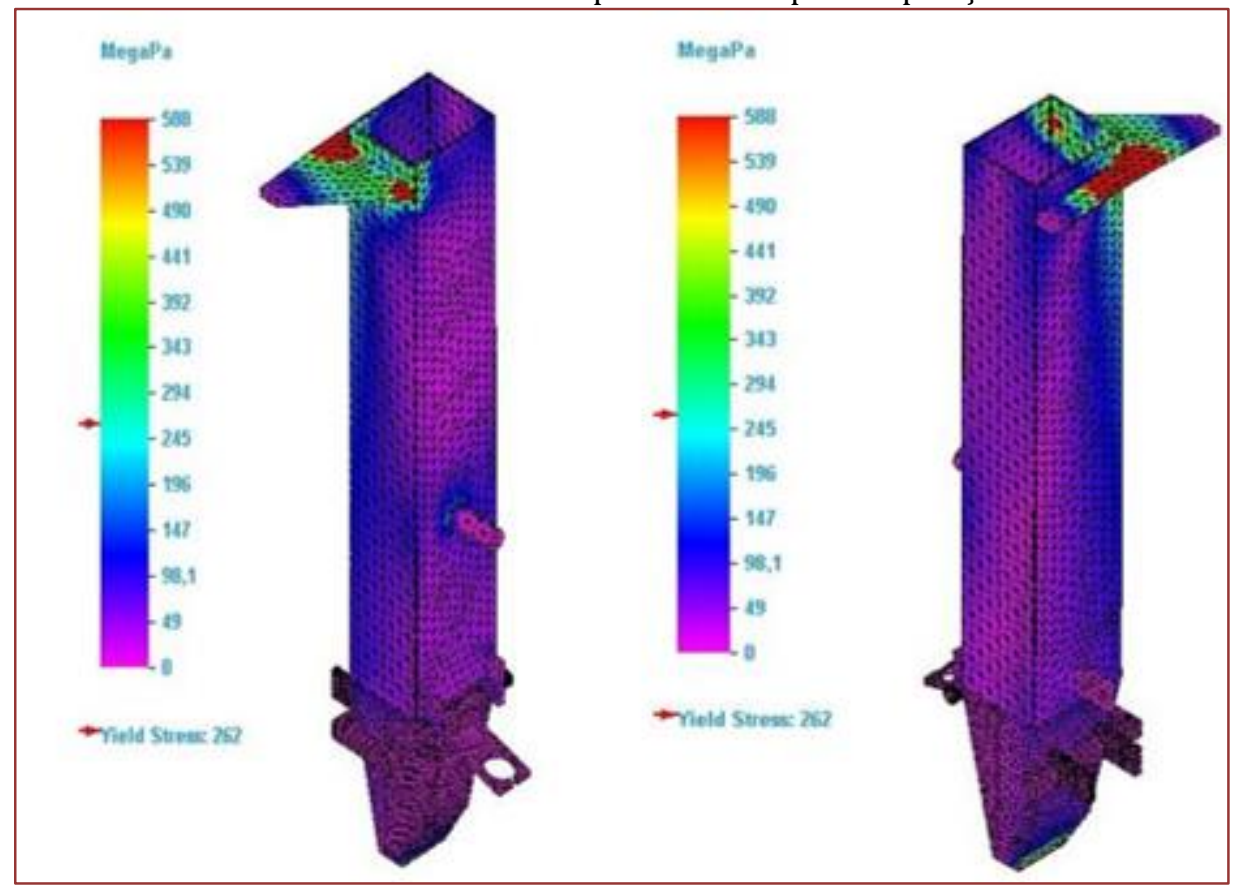

Observa-se na Figura 3 o protótipo da semeadora que foi construído para realizar a avaliação da distribuição de sementes de milho em campo e os resultados do teste realizado encontra-se na tabela 3. 
FIGURA 3. Protótipo da semeadora puncionadora utilizado para os ensaios em campo.

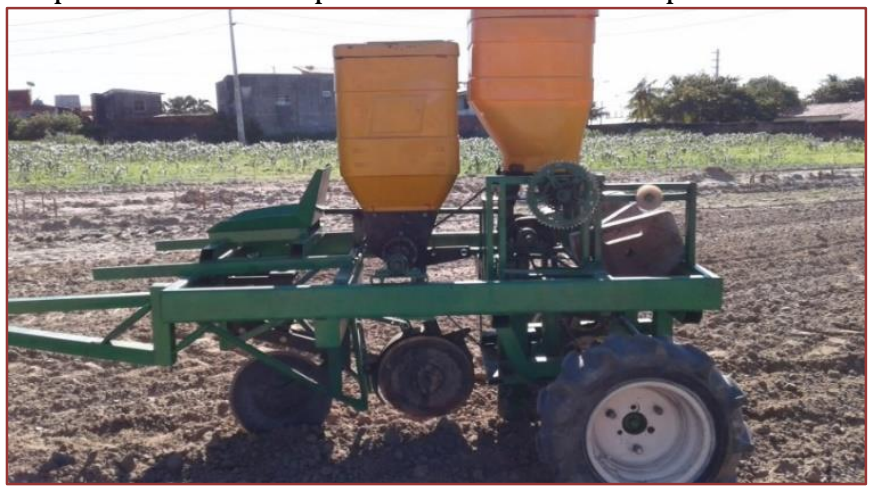

Verifica-se que o protótipo da semeadora puncionadora obteve 5,71\% de espaçamentos duplos e 94,28\% de espaçamentos aceitáveis, sendo assim o protótipo da semeadora puncionadora obteve ótimo índice de distribuição de sementes, já que 94,28 \% das sementes encontram-se dentro dos limites estabelecidos por Kurachi (1989).

TABELA 1. Avaliação de espaçamentos duplos, falhos, aceitáveis da semeadora puncionadora.

\begin{tabular}{|c|c|c|}
\hline Duplos & Aceitáveis & Falhos \\
\hline $4(5,71 \%)$ & $66(94,28 \%)$ & $0(0 \%)$ \\
\hline
\end{tabular}

Resultados semelhantes foram obtidos por Frabetti et al., (2011) ao avaliarem o desempenho do protótipo de uma semeadora puncionadora trabalhando na velocidade de $4 \mathrm{~km} . \mathrm{h}^{-1}$ obtiveram regularidade de distribuição de 95,08\%. Sendo assim a semeadora avaliada apresentou desempenho ótimo, já que Torino e Klingensteiner (1983) consideram como desempenho ótimo as semeadoras que distribuem de 90 a $100 \%$ das sementes na faixa de espaçamentos aceitáveis, bom desempenho as que distribuem de $75 \%$ a $90 \%$, regular de $50 \%$ a $75 \%$ e insatisfatório abaixo de $50 \%$.

\section{CONCLUSÃO}

O protótipo apresentou ótimo índice de distribuição de sementes comprovando a eficiência do sistema puncionador para a elevação da qualidade do trabalho agrícola familiar e a análise de tensão do protótipo auxiliou de forma significativa, pois forneceu informações relevantes que foram levadas em consideração para realizar melhorias na estrutura do protótipo.

\section{REFERÊNCIAS}

[1] Albiero, D. Desenvolvimento e avaliação de máquina multifuncional conservacionista para a agricultura familiar. 2010. 244 f. Tese (Dourado em Engenharia Agrícola) - Universidade Estadual de Campinas, São Paulo, 2010.

[2] Frabetti, D. R.; Resend, R. C.; Queiroz, D. M.; Fernandes, H. C; Solza, C.M. Desenvolvimento e avaliação do desempenho de uma semeadora puncionadora para plantio direto de milho. Revista Brasileira de Engenharia Agrícola e Ambiental, v. 15, n. 2, p.199-204, 2011.

[3] Kurachi, S. A. H.; Costa, J. A. S.; Bernardi, J.A. et. al. Avaliação tecnológica de semeadoras e/ou adubadoras: tratamento de dados de ensaios e regularidade de distribuição longitudinal de sementes. Bragantia, Campinas, v. 48, n. 2, p. 249-262, 1989.

[4] Lima, A.A.C.; Oliveira, F.N.S.; Aquino, A.R.L. de. Limitações do uso dos solos do Estado do Ceará por suscetibilidade à erosão. Fortaleza: Embrapa Agroindústria Tropical, 2002. 19p. (Embrapa Agroindústria Tropical. Documentos, 54).

[5] Melo, R. P. Desenvolvimento e avaliação do protótipo de uma semeadora puncionadora para agricultura familiar. 2017. 134 f. Tese (Doutorado em Engenharia Agrícola) - Universidade Federal do Ceará.

[6] Pahl, G. et. al. Projeto na Engenharia: Fundamentos do desenvolvimento eficaz de produtos métodos e aplicações. São Paulo: Edgard Blucher, 2005.

[7] Teixeira, S. S. Projeto conceitual de uma semeadora de milho e feijão voltada para a agricultura familiar de base ecológica. 2008. 113 f. Dissertação (Mestrado em Ciências) - Universidade Federal de Pelotas, Pelotas, 2008. 


\section{Capítulo 13}

\section{Acidentes com tratores agrícolas na Região do Alto Vale do Itajaí - SC}

\section{Gabriel Ganancini Zimmermann}

\section{Fabrício Campos Masiero}

Ricardo Kozoroski Veiga

João Célio de Araújo

Djeimes Luiz Sadowski Celante

José Carlos Kusma

Adelino do Amaral

Resumo: Os acidentes de trabalho com máquinas agrícolas tornaram-se mais frequentes nas últimas décadas, principalmente em propriedades de agricultura familiar, fazendo necessário a identificação destes para que se possa implementar medidas preventivas. Desta forma buscou-se examinar a natureza e gravidade dos riscos de acidentes com máquinas agrícolas na região do Alto Vale do Itajaí, no Estado de Santa Catarina, em relação aos preceitos estabelecidos pela Norma Regulamentadora (NR) 31. Os dados foram obtidos a partir de um compilado de informações de acidentes em meios de comunicação regional, ocorridos no período de 2012 a 2018, totalizando 20 notícias a quais foram aplicadas ao método quantitativo. Os resultados apresentaram que as principais causas de acidentes são por capotamento e colisões com veículos em estradas públicas, como também a operação de condução do trator agrícola sem carga dentro da propriedade. A ocorrência de danos físicos graves prevaleceu em indivíduos do sexo masculino, com idade média de 29 anos, pertencente a cidades de Ituporanga e Agronômica, no período de 2017. Portanto foram alcançados avanços nas informações de acidentes com máquinas agrícolas na região, construindo futuramente o banco de dados para conhecimento e conscientização dos produtores rurais as medidas de segurança. 


\section{INTRODUÇÃO}

As atividades rurais são consideradas como as mais perigosas que existem para os trabalhadores, apresentando fatores negativos com relação à segurança. Os acidentes de trabalho, bem como as doenças profissionais, constituem-se em flagelos que atingem todos os países, originando como consequência a redução da capacidade física dos trabalhadores e perdas de vidas humanas (Araripe et al., 2012).

Nas atividades agrícolas, as operações mecanizadas são as que oferecem maiores riscos de acidentes. Isso porque elas pressupõem não somente o emprego de máquinas, mas a interferência do homem, formando um sistema homem-máquina, quando esse conjunto não é eficiente, ocorre o acidente (Fernandes et al., 2014).

A norma regulamentadora (NR) 31 compreende estabelecer os preceitos a serem observados na organização e no ambiente de trabalho, de forma a tornar compatível o planejamento e o desenvolvimento das atividades da agricultura, pecuária e silvicultura (MTE, 2018). Tais normas técnicas são comumente desrespeitadas por operadores e outros trabalhadores, levando a ocorrência de diversos tipos de acidentes, que em alguns casos repentinos podem levar a óbito.

0 objetivo desta pesquisa no que diz respeito ao estudo dos riscos profissionais na agricultura, foi examinar a natureza e gravidade dos riscos de acidentes com máquinas agrícolas na região do Alto Vale do Itajaí, no Estado de Santa Catarina, em relação aos preceitos estabelecidos pela NR 31. Contudo foi necessário analisar os meios capazes de combater as causas diminuindo ou eliminando tais riscos.

\section{MATERIAL E MÉTODOS}

0 presente estudo foi realizado no Instituto Federal Catarinense (IFC), no Laboratório de Mecanização Agrícola (LabMec), situado município de Rio do Sul-SC.

Os dados de pesquisas foram obtidos a partir de um compilado de informações de acidentes em meios de comunicação regional, ocorridos no período de 2012 a 2018, totalizando 20 notícias a quais foram aplicadas ao método quantitativo.

Para mensuração dos dados obtidos, utilizou-se o método quantitativo de processamento, adotando discussões de informações em modelo numérico, auxiliando na tomada racional de decisões gerenciais, e substituindo as disposições empíricas utilizadas em grande escala conforme Bachini \& Chicarino, (2018).

Analisou-se os motivos dos acidentes com tratores agrícolas em relação a desobediência das normas regulamentadoras especificas para tais atividades NR 31, elaborando a listagem das notícias.

A adoção do método de indicadores de acidentes do trabalho, possui função de mensurar a exposição dos trabalhadores aos níveis de risco inerentes à atividade econômica, permitindo o acompanhamento das flutuações e tendências históricas dos acidentes e seus impactos nas empresas e na vida dos trabalhadores (Corrêa et al., 2005).

Dentre os aspectos importantes nos indicadores de acidentes do trabalho, existem duas variáveis consideráveis. A taxa de incidência é um indicador da intensidade com que acontecem os acidentes do trabalho, e a taxa de mortalidade mede a relação entre o número total de óbitos decorrentes dos acidentes do trabalho verificados no ano e a população exposta ao risco de se acidentar.

Assim com estes métodos serão coletados os dados para o desenvolvimento da pesquisa, porém existe outras ferramentas para o auxílio da avaliação quantitativa, sendo este o cálculo da probabilidade de ocorrência de acidentes.

O risco (R) é a multiplicação da gravidade de um efeito pela frequência de uma causa. Em análises de segurança a frequência de uma causa é definida através da probabilidade de ocorrência da causa (P), enquanto a gravidade do efeito causado é quantificada em termos do dano causado (D), conforme Eq. 1:

$$
\mathrm{R}=\mathrm{D} \times \mathrm{P}
$$

O dano pode ser estimado quantitativamente, como por exemplo o número de pessoas feridas por capotamento do trator agrícola, e suas probabilidades de ocorrência são tratadas como frequências ou 
probabilidades. Em caso de haver mais de uma provável causa ou mais de um dano causado pela mesma causa, o risco total é calculado como a perda estimada (Schlosser et al., 2002).

Contudo a análise quantitativa de riscos fornece medidas numéricas do risco das operações entorno dos trabalhadores ou equipamentos. Desta forma é importante considerar os resultados históricos de vários acidentes, o porquê do descumprimento da NR 31, quais os tipos, e qual operação ocorreu maior número de acidentes.

\section{RESULTADOS E DISCUSSÃO}

\subsection{ANÁLISE DA CAUSA DOS ACIDENTES}

As principais causas de acidentes com máquinas agrícolas (Figura 1) na região do Alto Vale do Itajaí ocorreram em grande parte por capotamento e colisões com veículos em estradas, ambos correspondendo a $70 \%$ dos casos, e outros $30 \%$ são divididos em atropelamento e perda de direção.

Figura 1. Causas específicas dos acidentes

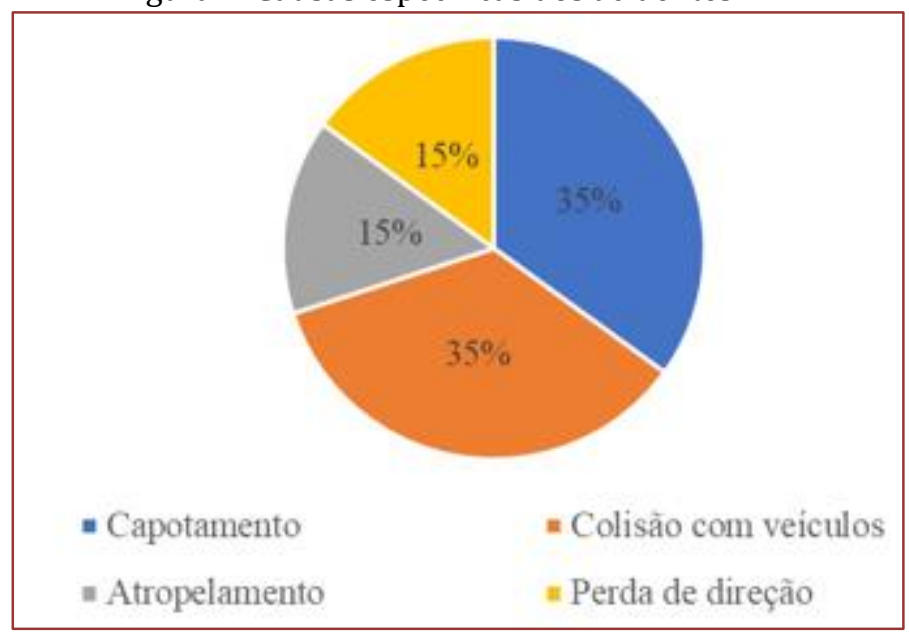

Em relação a NR 31 estes acidentes enquadraram no parágrafo §31.12.1, onde as máquinas e implementos devem ser utilizados segundo as especificações técnicas do fabricante e dentro dos limites operacionais e restrições por ele indicados, e operados por trabalhadores capacitados, qualificados ou habilitados para tais funções.

\subsection{ANÁLISE DAS ATIVIDADES MECANIZÁVEIS}

A predominância da agricultura familiar na região engloba atividades comuns para manutenção das propriedades, como o transporte de carretas e serviços gerais (Figura 2). Segundo pesquisas a condução do trator agrícola sem carga dentro da propriedade foi a que apresentou maiores índices de acidentes com $45 \%$ dos casos, seguido pela condução sem carga em rodovias, resultando em colisões frontais com outros veículos somando 35\%, e por último a condução com carga (carreta) dentro da propriedade finalizando os $20 \%$ respectivamente. 
Figura 2. Atividades mecanizáveis

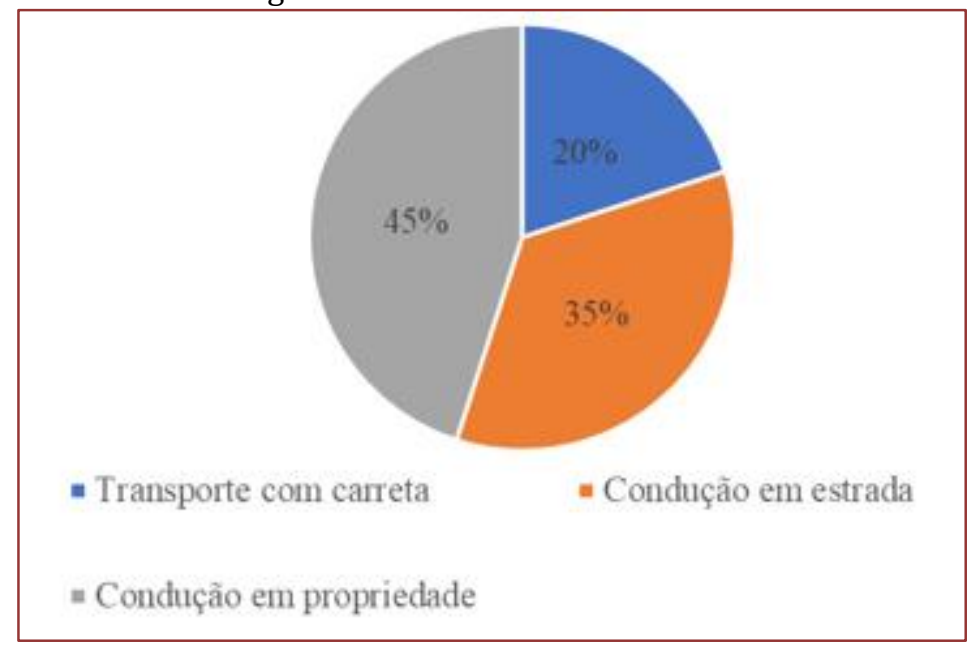

\subsection{MAGNITUDE DOS DANOS FÍSICOS}

Os danos físicos (Figura 3) resultados dos acidentes foram em maior quantidade de ferimentos graves 45\%, óbitos 30\%, ferimentos leves 30\% e ferimentos médios com 5\% respectivamente. Os ferimentos graves são aqueles que lesionam o corpo de forma permanente como amputação e escoriações. Os ferimentos médios e leves resultam em lesões não tão graves e de fácil controle.

Figura 3. Danos físicos

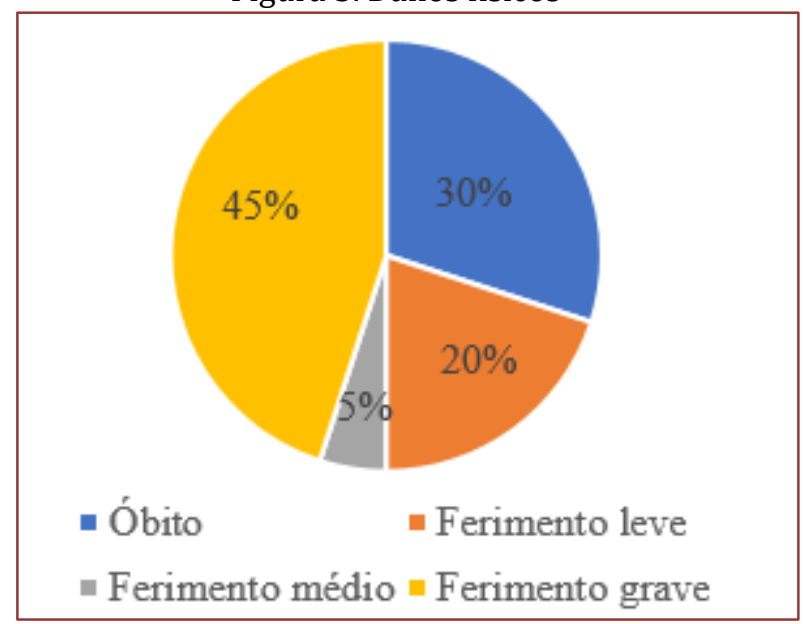

\subsection{SEXO E IDADE}

A mecanização agrícola desde seus primórdios é destinada a trabalho masculino, não sendo diferente nas pesquisas relacionadas aos acidentes agrícolas, onde os homens possuem o total de $100 \%$ de envolvimento como operador do trator nos casos, conforme a Figura 4a.

Em relação a idade dos operadores (Figura 4b), foi realizada a média e desvio padrão de 29 anos e 18,09. A faixa de idade de 26 a 58 anos apresentou os maiores acidentes, devido ser a amplitude de idade comum de trabalhadores rurais na agricultura familiar da região. 
Figuras 4a e 4b. Sexo e idades dos operadores
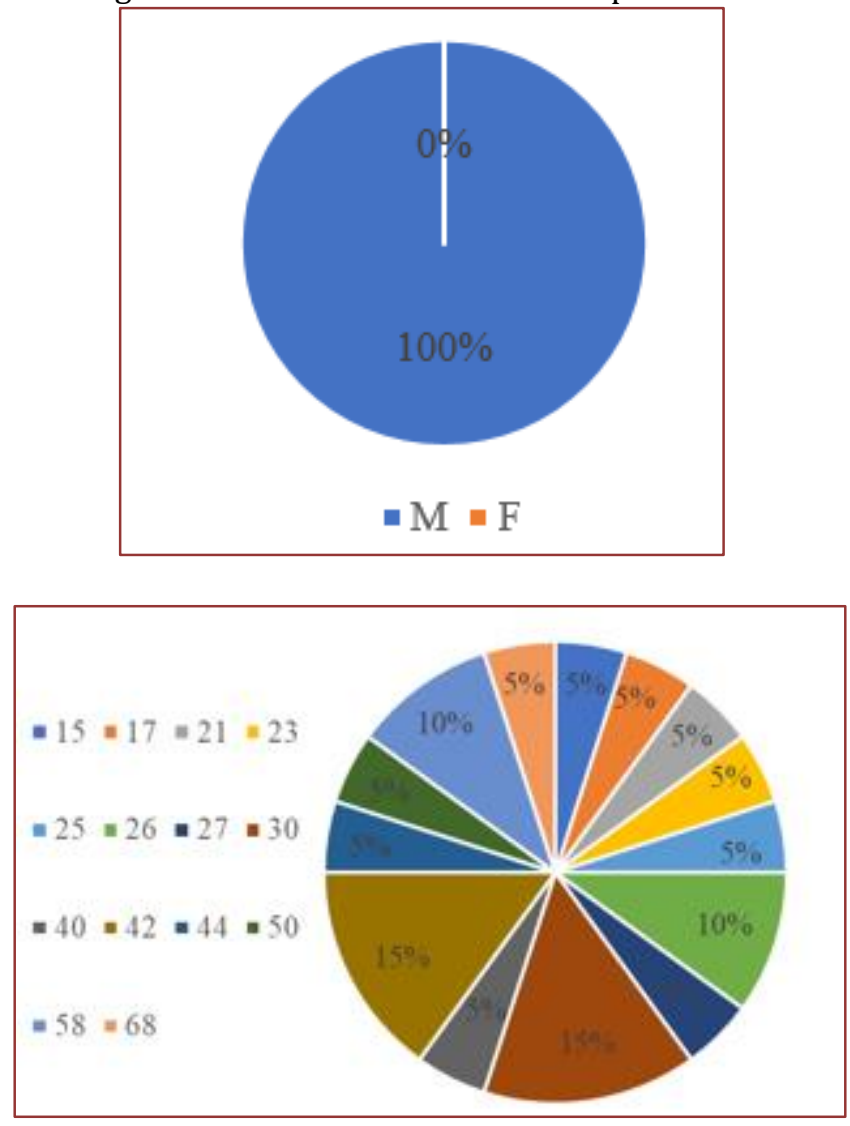

\subsection{ENQUADRAMENTO DAS CIDADES}

Grande parte das cidades do Alto Vale do Itajaí possui como fonte econômica principal a agricultura familiar, possuindo grande número de pequenas propriedades e maquinários agrícolas, predominantemente microtratores. As cidades de Ituporanga, Presidente Getúlio e Agronômica possuem os maiores índices de acidentes com tratores agrícola, seja dentro da propriedade ou em estradas (Figura 5). Isto ocorre pela grande movimentação produtiva local e a falta de conhecimento dos operadores em conhecer as normas de segurança de maneira geral.

Figura 5. Relação das cidades do Alto Vale do Itajaí-SC

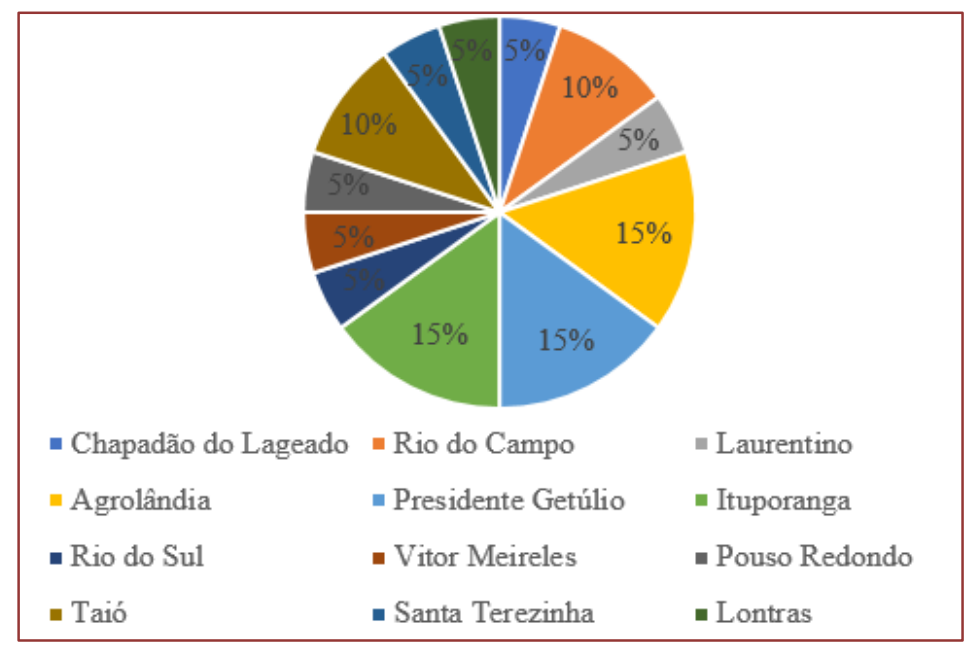




\subsection{AVALIAÇÃO DOS ANOS DE ACONTECIMENTO}

0 trabalho buscou trazer informações dos acidentes que estivessem arquivados nos meios de informações locais, porém com a limitação dos dados encontrou-se informações a partir do ano de 2012 até 2018 (Figura 6). O ano de 2017 ocorreu maior número de acidentes em relação aos anos avaliados, correspondendo a $45 \%$ respectivamente.

Figura 6. Relação dos anos ocorridos

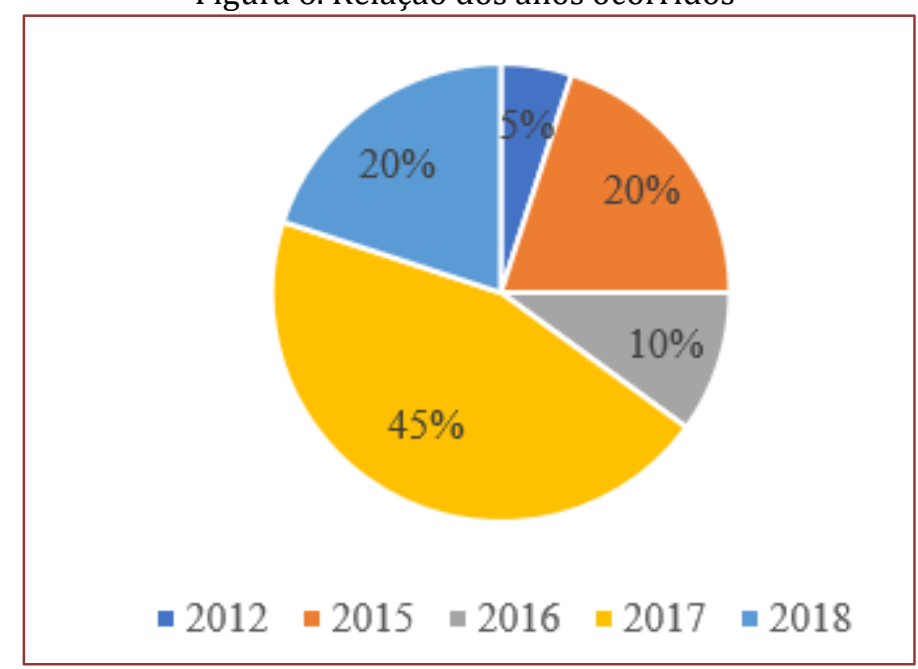

\section{CONCLUSÃO}

Mediante o exposto claramente observa-se a magnitude dos acidentes envolvendo tratores agrícolas no Alto Vale do Itajaí, satisfazendo as hipóteses e objetivos iniciais. A maior causa do acidentes reportados foram o capotamento e colisão com veículos com aproximadamente $70 \%$ dos casos. 0 trabalho grandiosamente agregou informações inéditas, contribuindo para o conhecimento das principais infrações em relação a NR 31, alcançando grandes avanços na busca de dados nos meios de comunicações regionais. O não uso do cinto de segurança em tratores e não atendimento as normas de segurança no deslocamento com as máquinas são a maioria dos atos inseguros cometidos.

AGRADECIMENTO: Conselho Nacional de Desenvolvimento Científico e Tecnológico (CNPq) pela bolsa concedida para realização dest trabalho.

\section{REFERÊNCIAS}

[1] Araripe, P. et al. (2012) Segurança no trabalho com máquinas agrícolas. Piracicaba: Pro-jepec, 20 p.

[2] Bachini, N.; Chicarino, T. S. (2018) Os métodos quantitativos, por cientistas sociais brasileiros: entrevistas com Nelson do Valle Silva e Jerônimo Muniz. Sociedade e Estado, v. 33, n. 1, p.251-279. http://dx.doi.org/10.1590/s0102-699220183301010.

[3] Corrêa, M. I.; Yamashita, Y. R.; Franco, A. V. F.; Ramos, H. H. (2005) Verificação de requisitos de segurança de tratores agrícolas em alguns municípios do Estado de São Paulo. rev. Bras. Saúde ocup. V. 30.

[4] Fernandes, H. C.; Madeira, N. G.; Teixeira, M. M.; Cecon, P. R.; Leite, D. M. (2014) Acidentes com Tratores Agrícolas: Natureza, Causas e Consequências. Engenharia na agricultura. Viçosa. v.22, n.4, 361-371 p.

[5] Ministério do Trabalho e Emprego (MTE). NR 31: NR 31 - Segurança e saúde no trabalho na agricultura, pecuária silvicultura, exploração florestal e aquicultura. Brasília: Brasil, 2018. 53 p.

[6] Schlosser, J. F.; Debiasi H.; Parcianello G.; Rambo L. (2002) Caracterização dos acidentes com tratores agrícolas. Ciência Rural, v.32, n.6. 


\section{Capítulo 14}

\section{Avaliação econômica da influência dos tipos de rodado}

no consumo de combustível em trator agrícola

\section{Aldir Carpes Marques Filho \\ Jefferson Sandi \\ Murilo Battistuzzi Martins \\ Maura Seiko Tsutsui Esperancini \\ Kléber Pereira Lanças}

Resumo: Pneus agrícolas possuem características construtivas diferenciadas, com detalhes específicos de desenho e matéria prima que podem influenciar significativamente o consumo de combustível e a compactação do solo. 0 objetivo deste trabalho foi avaliar o desempenho econômico de três conjuntos de pneus agrícolas diagonais R1, R2 e R3 com características distintas de fabricação, sob o ponto de vista de consumo de combustível e compactação de solo. Verificou-se que o conjunto R3 apresentou o melhor resultado nos ensaios de campo e de laboratório, bem como seu custo de operação foi o mais baixo dentre os conjuntos avaliados, porém seu valor de mercado foi o mais elevado, concluindo-se que o valor baixo de mercado não é parâmetro confiável para a tomada de decisão para aquisição de pneus.

Palavras-Chave: pneus agrícolas, consumo de combustível, compactação do solo. 


\section{INTRODUÇÃO}

A correta escolha do tipo de pneu a ser instalado nas máquinas agrícolas é uma decisão de difícil equacionamento. Feitosa et al. (2015), afirmaram que a pressão de inflação do pneu de um trator, a velocidade de trabalho e as características construtivas do rodado afetam diretamente a compactação do solo. Os pneus agrícolas possuem características construtivas diferenciadas, com detalhes específicos de desenho e matéria prima que podem influenciar significativamente o consumo de combustível e a compactação do solo durante as operações agrícolas. Um dos principais fatores que as empresas agrícolas e produtores rurais, detentores de frotas volumosas de máquinas e equipamentos levam em consideração no momento da decisão por qual modelo de pneus utilizar nas atividades produtivas é o preço de mercado dos pneus.

Torna-se necessário investigar se pneus com tecnologias construtivas mais elaboradas e por conseguinte maior preço final de mercado podem realmente incrementar a produtividade das culturas, reduzir a compactação ou mesmo reduzir o consumo de combustível dos conjuntos motomecanizados. Berisso et al. (2013) afirmaram que ensaios realizados com penetrômetros em transepto na faixa de interação rodadosolo fornecem informações confiáveis referente à distribuição de cargas no solo.

Objetivou-se avaliar economicamente a performance operacional de três conjuntos de pneus de construção diagonal, com mesma dimensão, porém com características construtivas diferenciadas em ensaio de barra de tração em pista indeformável (concreto) de acordo com normatização internacional.

\section{MATERIAL E MÉTODOS}

0 ensaio foi realizado na Faculdade de Ciências Agronômicas da UNESP, campus Botucatu. 0 primeiro ensaio foi conduzido em pista de concreto padronizada de acordo com as normas constantes no código 2 da Organização para Cooperação e Desenvolvimento Econômico (OCDE) e em laboratório na Unidade Fixa de Ensaios de Pneus (UFEP). O procedimento adotado consistiu em realizar frenagens controladas na Unidade Móvel de Ensaios na Barra de Tração (UMEB) para aplicação de cargas controladas ao trator, iniciando-se com o trator em movimento, até estabilização da velocidade e com máxima rotação do motor, realizando-se então a coleta dos dados em um trecho de deslocamento de $25 \mathrm{~m}$.

Foi utilizado para os ensaios em pista um trator com potência máxima disponível no motor de 70,6 kW a $2300 \mathrm{rpm}$ (ISO/NBR 1585), 4 cilindros e $4400 \mathrm{~cm}^{3}$ de cilindrada no motor com sistema de admissão turbo alimentado. A massa do trator com tanque cheio foi determinada através de pesagem individual dos rodados em contato com uma balança de solo, totalizando $5240 \mathrm{~kg}$ incluindo operador e lastros sólido e líquido. Todos os conjuntos de pneus foram ensaiados com a mesma distribuição de massa no trator, sendo $65 \%$ no eixo traseiro e 35\% no eixo dianteiro conforme recomendado por MIALHE (1996).

Foram ensaiados três conjuntos de rodados pneumáticos de construção diagonal de fabricantes e modelos distintos, sendo eles R1, R2 e R3 respectivamente. Cada conjunto completo formado por quatro pneus, sendo dois com dimensões 18.4-34 instalados nos rodados traseiros e dois com dimensões de 14.9-24 instalados nos rodados dianteiros.

As avaliações dos rodados foram feitas em duas velocidades V1 $\left(3 \mathrm{~km} \cdot \mathrm{h}^{-1}\right)$ e V2 $\left(5 \mathrm{~km} \cdot \mathrm{h}^{-1}\right)$ em pista de concreto. As pressões de inflação do rodado R1 foi de $62 \mathrm{kPa}$ nos rodados dianteiros e $83 \mathrm{kPa}$ nos rodados traseiros. Em R2 a pressão de inflação dos rodados dianteiros foi de $55 \mathrm{kPa}$ e $97 \mathrm{kPa}$ nos traseiros, e em R3 os rodados dianteiros foram calibrados com $69 \mathrm{kPa}$ de pressão e os rodados traseiros foram calibrados com $83 \mathrm{kPa}$.

Foram utilizados dois medidores de fluxo volumétrico Flowmate Oval MIII LSF-41, sendo o primeiro instalado na linha de alimentação de combustível e o segundo na linha de retorno do combustível para o tanque. Utilizou-se um scanner automatizado munido com trena laser analógica modelo 96M ODS/V5070-421 para coleta dos dados de profundidade de decalque do pneu sobre o solo para obter uma imagem em três dimensões da área de contato do pneu com o solo.

0 penetrômetro eletro-mecânico utilizado foi constituído de um motor elétrico e uma haste de aço padronizada contendo uma ponteira cônica de ângulo sólido de $30^{\circ}$, com diâmetro de $20,27 \mathrm{~mm}$ e área $323 \mathrm{~mm}^{2}$, de acordo com as características estruturais e operacionais definidas por norma da ASABE (2011), e uma célula de carga com capacidade de $500 \mathrm{kgf}$ trabalhando na velocidade de penetração de 30 $\mathrm{mm} \mathrm{s}^{-1}$. Os mapas de compactação do solo com cada tecnologia de pneu utilizada forma gerados com auxílio do software Surfer 11.0. 
A metodologia para análise de custo, depreciação, taxa de abrigo e seguro das máquinas foi realizada de acordo com ASABE (2012). Considerou-se para análise econômica um uso anual estimado de 1000 horas para o trator, e uma taxa de juros de $7 \%$ ao ano. Os valores de peças e equipamentos, bem como de mão de obra para formação do custo horário de uso de cada tecnologia foi obtido através de pesquisa no boletim AGRIANUAL (2018), bem como através de consulta em sites especializados e de fabricantes.

\section{RESULTADOS E DISCUSSÃO}

De acordo com os dados obtidos pode-se determinar o recalque de cada conjunto e sua interação rodadosolo, de acordo com os mapas de isolinhas apresentados é possível verificar que com a mesma carga aplicada cada rodado interage de forma diferenciada com o solo.

FIGURA 2: Mapas de isolinhas e distribuição de forças na interação dos rodados a. R1; b. R2 e c. R3 sob carga de 1790kgf na Unidade Fixa de Ensaios de Pneus.

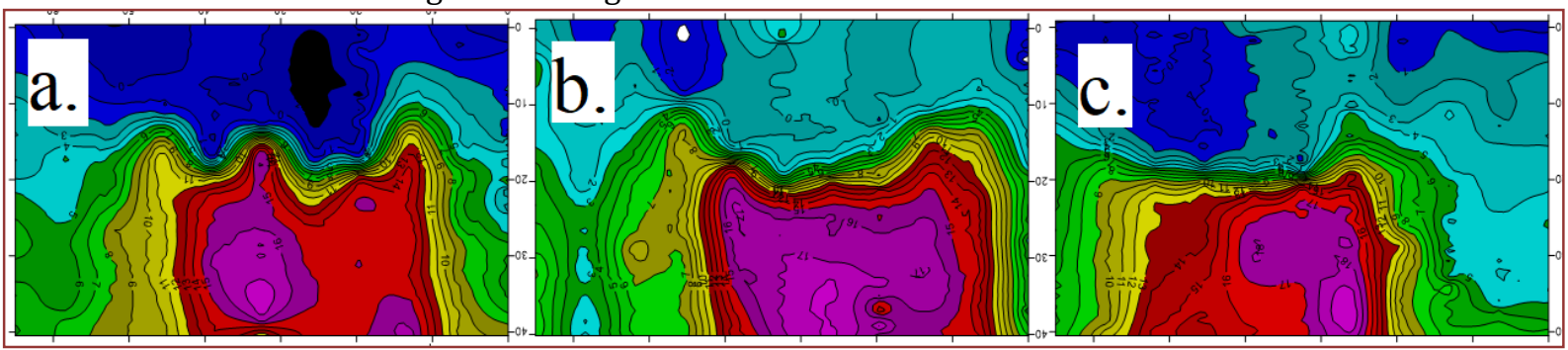

Na Figura 2b. é possível verificar que o conjunto de pneus R2 apresenta uma intensidade de compactação mais distribuída ao longo do perfil de solo, e a intensidade da compactação é maior do que R1 e R3, tal fato pode estar associado à que este modelo de pneu trabalhe com pressões maiores de inflação $96,5 \mathrm{kPa}$, isso pode ter influenciado na maior carga de compactação. Os conjuntos R1 e R3 trabalham com pressões de inflação entre 60 e $83 \mathrm{kPa}$ e a distribuição de cargas foi semelhante. Estas tecnologias são de mesmo fabricante, e a pressão de trabalho propiciou uma distribuição uniforme das cargas, sem que o ponto de compactação máxima alcançasse valores elevados em profundidade. Soracco et al. (2015) em estudo na compactação dinâmica do solo afirmam que o tráfego de máquinas influência negativamente todas as características de solo, impactando na produtividade das culturas.

Com relação aos valores de mercado de cada tecnologia foi realizado um estudo de caso considerando os valores de custo fixo e variável para cada conjunto. A Tabela 1 descreve os custos fixos e variáveis de cada conjunto de rodado, além de custos fixos do trator.

TABELA 1: Estimativa de custos fixos e variáveis para conjunto Trator e rodados em cada marcha de trabalho avaliada de acordo com ASABE (2012).

\begin{tabular}{|c|c|c|c|c|c|c|c|c|c|}
\hline & \multicolumn{3}{|c|}{ Custos Fixos } & \multicolumn{6}{|c|}{ Custos Variáveis } \\
\hline & $\begin{array}{l}\text { Valor } \\
\text { inicial } \\
(\mathrm{R} \$)\end{array}$ & $\begin{array}{c}\text { Depreciação } \\
\text { + Juros } \\
\text { (R\$/ano) }\end{array}$ & $\begin{array}{c}\text { Total Fixo } \\
\text { Anual } \\
(\mathrm{R} \$ / \mathrm{h})\end{array}$ & $\begin{array}{c}\text { Consumo } \\
(\mathrm{L} / \mathrm{h})\end{array}$ & $\begin{array}{l}\text { Preço } \\
\text { Diesel } \\
(\mathrm{R} \$ / \mathrm{L})\end{array}$ & $\begin{array}{c}\text { Custo } \\
\text { Combustível } \\
(\mathrm{R} \$ / \mathrm{h})\end{array}$ & $\begin{array}{c}\text { Custo } \\
\text { Lubrificantes } \\
(\mathrm{R} \$ / \mathrm{h})\end{array}$ & $\begin{array}{c}\text { Custo } \\
\text { Operador } \\
(\mathrm{R} \$ / \mathrm{h})\end{array}$ & $\begin{array}{c}\text { Total } \\
\text { Variável } \\
(\mathrm{R} \$ / \mathrm{h})\end{array}$ \\
\hline Trator & $131.000,00$ & $16.473,25$ & 249,88 & & & & & & \\
\hline Conjunto R1V1 & $11.270,96$ & $2.620,50$ & 2,62 & 6,81 & 3,40 & 23,13 & 3,47 & 19,79 & 46,39 \\
\hline Conjunto R1V2 & $11.270,96$ & $2.620,50$ & 2,62 & 6,78 & 3,40 & 23,03 & 3,45 & 19,79 & 46,27 \\
\hline Conjunto R2V1 & $10.182,28$ & $2.367,38$ & 2,36 & 7,36 & 3,40 & 25,00 & 3,75 & 19,79 & 48,54 \\
\hline Conjunto R2V2 & $10.182,28$ & $2.367,38$ & 2,36 & 6,96 & 3,40 & 23,64 & 3,55 & 19,79 & 46,98 \\
\hline Conjunto R3V1 & $18.997,72$ & $4.416,97$ & 4,41 & 7,56 & 3,40 & 25,68 & 3,85 & 19,79 & 49,32 \\
\hline Conjunto R3V2 & $18.997,72$ & $4.416,97$ & 4,41 & 6,51 & 3,40 & 22,11 & 3,32 & 19,79 & 45,22 \\
\hline
\end{tabular}


Verifica-se na Tabela 1 que o custo do conjunto R3 é o mais elevado, pois trata-se de tecnologia de ponta na qualidade de lonas e construção do pneu, da mesma forma o custo total anual é o mais elevado quando comparado com a tecnologia R1 e R2.

É possível verificar que o conjunto R3 proporciona menor consumo de combustível dentre os modelos ensaiados. Essa redução no consumo de combustível ocorreu possivelmente pela maior eficiência tratória e menor patinagem do rodado.

A avaliação de mil horas de uso do trator agrícola, está abaixo da realidade brasileira, onde estas máquinas são usadas por maior quantidade de tempo, assim o conjunto de rodado que apresentou os menores custos variáveis será amortizado mais rapidamente e retornará em benefícios econômicos o valor de seu investimento de forma mais acelerada.

É fundamental obter maiores informações com relação à interação rodado-solo e consumo de combustível, visto que são dois entraves importantes na agricultura moderna, o primeiro afeta diretamente a produtividade e o segundo apresenta a maior parte dos custos de um empreendimento agrícola.

\section{CONCLUSÕES}

Selecionar pneus agrícolas balizando-se somente por oferta e preços de mercado não representa racionalidade na adequação de tecnologia e implantação no campo. 0 presente trabalho demonstrou que pneus com maior valor de mercado podem representar economia de combustível e redução nos custos variáveis das operações.

\section{REFERÊNCIAS:}

[1] Asabe - American Society of Agricultural and Biological Engineers. Asabe Standards 2011, EP4963 Agricultural machinery management data. St. Joseph, Michigan, USA, p. 6, 2011.

[2] Asabe - American Society of Agricultural and Biological Engineers. Asabe Standards 2012, D4977 Agricultural machinery management data. St. Joseph, Michigan, USA, p. 8, 2012.

[3] Berisso, F. E.; Schjonningam P.; Lamandé, M.; Weisskopf, P.; Stettler, M.; Keller, T. Effects of the stress field induced by a running tyre on the soil pore system. Soil and Tillage Research, Volume 131, 36-46, 2013.

[4] Feitosa, J. R.; Fernandes, H. C.; Teixeira, M. M.; Cecon, P. R. Influência da pressão interna dos pneus e da velocidade de deslocamento nos parâmetros operacionais de um trator agrícola e nas propriedades físicas do solo. Revista Eng. Agrícola, Jaboticabal, v.35, n.1, p.117-127, 2015.

[5] Mialhe, L.G. Máquinas Agrícolas: Ensaios e certificação. Fealq - Fundação de estudos agrários Luiz de Queiroz, 722p. Piracicaba, 1996.

[6] Soracco, G. C.; Lozano, L. A.; Villareal, R.; Palancar, T. C.; Collazo, D. J.; SARLI, G. O.; Filgueira, R. R. Effects of compaction due to machinery traffic on soil pore configuration. Rev. Bras. Ci. Solo, v. 39, p.408-415, 2015. 


\section{Capítulo 15}

Bambucilga: Uma alternativa para criação de suínos e a conformidade orgânica

\section{Luã Carlos Colaço \\ Cátia Hermes \\ Eduardo Javier Marone \\ Valcir Inácio Wilhelm \\ Fabiana Teixeira Hoinacki}

Resumo: Os bolsistas do Programa Paraná Mais Orgânico $(\mathrm{P}+0)$, núcleo Centro Paranaense de Referência em Agroecologia (CPRA), têm a função de visitar propriedades rurais para auxiliar produtores no processo de Certificação Orgânica. Ao longo das visitas se percebeu que a criação de suínos era fonte de contaminação de solo, água e ambiente, não respeitando os princípios da legislação orgânica. 0 objetivo da equipe P+0/CPRA foi a construção de uma Bambucilga em forma de cama sobreposta como protótipo no CPRA, para posterior multiplicação da proposta nas propriedades rurais. Este foi finalizado em abril de 2018 e até julho de 2018 o grupo de produtores certificados orgânicos na forma de Organismo de Controle Social da cidade de Rio Branco do Sul (PR), já haviam reproduzido três destas estruturas. Sendo assim, o objetivo da proposta foi atingido, ajustando a adequação das propriedades à certificação orgânica.

Palavras-chave: Bambu, Construção, Agroecologia. 


\section{INTRODUÇÃO}

O Programa Paraná Mais Orgânico (P+O) teve início no ano de 2009 e é uma parceria entre a Secretaria da Ciência, Tecnologia e Ensino Superior (SETI) com o Instituto de Tecnologia do Paraná (TECPAR), as Instituições Estaduais de Ensino Superior e o Centro Paranaense de Referência em Agroecologia (CPRA). 0 Programa é executado por equipes multidisciplinares de profissionais e estudantes de graduação que compõem os Núcleos de Certificação que estão distribuídos em oito cidades do estado do Paraná.

Os bolsistas do P+O/CPRA são responsáveis por realizar visitas às propriedades rurais para auxiliar os produtores que desejam obter a certificação orgânica. Durante estas visitas os bolsistas observaram que os produtores que têm a intenção de certificar a produção primária vegetal prestavam pouca atenção nas questões higiênico-sanitárias, no bem estar dos seus animais para consumo próprio e nos aspectos ambientais relacionados a estes. Existia pouca preocupação com práticas de manejo que evitassem a contaminação de solo e água pelos resíduos gerados por estes animais, o que afrontava diretamente os aspectos ambientais da conformidade orgânica.

A principal fonte de contaminação eram as pocilgas construídas nas beiras de riachos, açudes e córregos, que muitas vezes, possuíam condições precárias de infraestrutura. Uma das consequências disto era o escorrimento de fezes e urina suínas para dentro do recurso hídrico, contaminando este com coliformes fecais. Além disto, o fator bem-estar animal era pouco considerado, pois a densidade animal por pocilga era sempre muito alta, de forma que os animais demonstravam dificuldades para deitar e se locomover dentro da estrutura, ou ainda, ter acesso à água e comida sem motivar brigas.

Neste contexto, no mês de março de 2018 o núcleo P+O/CPRA teve como objetivo construir uma pocilga que pudesse servir como modelo de estrutura que minimizasse os impactos ambientais produzidos pela forma de criação de suínos citada acima, bem como garantir o conforto e bem estar destes animais de acordo com o que rege a Instrução Normativa no 46 de 6/10/2011 (Brasil, 2011). Também se objetivou a multiplicação da estrutura para os produtores atendidos pelo núcleo e sua divulgação através de duas cartilhas e um vídeo temático sobre o assunto.

\section{DESCRIÇÃO DA EXPERIÊNCIA}

A construção foi chamada de "Bambucilga", pois tem como base a utilização de bambu, além de solo cimento, cepilho e telhas reaproveitadas. A escolha dos materiais, cujas características de serem recicláveis, terem baixo custo, serem renováveis e biodegradáveis, vão de encontro com a área de Engenharia Alternativa existente no CPRA. Esta área busca desenvolver tecnologias de baixo custo com eficiência, aproveitando inclusive materiais que já existam na propriedade reduzindo os custos de sua implantação.

A instalação possui seis metros quadrados com o piso dividido em duas partes. A primeira possui quatro metros quadrados, onde há um fosso com 50 centímetros de profundidade, preenchido com cepilho. Toda esta área é recoberta com solo cimento para evitar que fezes e urina entrem em contato direto com o solo e contaminem lençol freático. A segunda possui dois metros quadrados, construída de concreto, sendo este o local destinado à alimentação dos animais. Este tipo de estrutura foi chamada de pocilga em forma de cama sobreposta por pesquisadores da Embrapa na década de 90 (Dalla Costa, 2006).

Além de absorver os dejetos dos animais sem contaminar o solo e água, este tipo de cama permite que ocorra um processo de compostagem durante a estadia dos animais na instalação, já que existem ali todos os componentes químicos necessários. 0 componente carbônico, cuja fonte é o cepilho; o componente nitrogenado e a umidade, representado pelas fezes e urina; e o oxigênio que é incorporado à cama no momento do revolvimento natural desta pelos animais ou, eventualmente, pelo produtor. Desta forma, quando houver a saturação da cama pelos dejetos é possível utilizá-la como integrante de uma pilha de compostagem para ser utilizada em áreas de produção primária vegetal da propriedade. Assim, se fecham ciclos produtivos sem gerar resíduos nocivos que afrontem a legislação orgânica e que demonstrem a importância e os benefícios da interação entre produção animal e vegetal na produção orgânica. 


\section{RESULTADOS}

A conclusão da obra foi em abril de 2018 (Imagem 1A). Após esta foi realizado um evento, que dentre outras atividades, divulgou a instalação através de um minicurso e entrega da primeira cartilha temática cujo título é “Caderno de Sugestões: Criação de Suínos em Cama Sobreposta” (Colaço et al., 2017).

Figura 1. Estrutura alternativa à criação de suínos, denominada "Bambucilga" e construída utilizando bambu, solo cimento, cepilho e telhas reaproveitadas. A: Estrutura construída no Centro de Agroecologia,

Pinhais - PR. B: Estrutura construída junto aos produtores de Rio Branco do Sul - PR.

a)

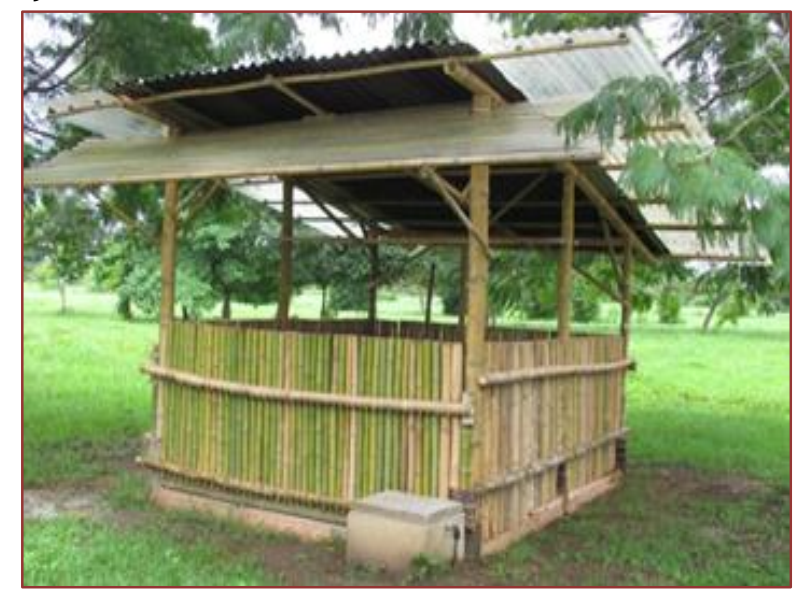

b)

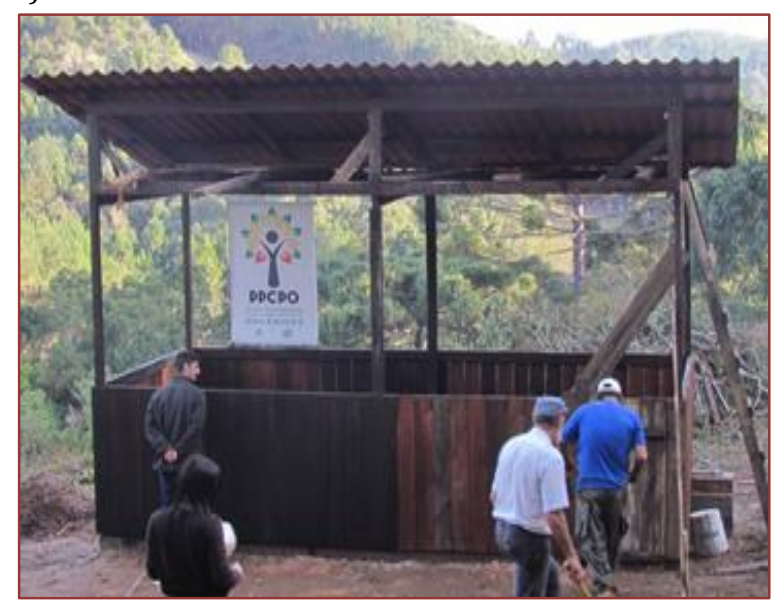

O evento e as posteriores visitas ao grupo Associação do Conselho Municipal de Desenvolvimento Agrícola de Rio Branco do Sul - ACARS, geraram a demanda pela construção da "Bambucilga", e com isso foi solicitado auxilio do núcleo P+O/CPRA para orientações. 0 grupo cuja certificação orgânica é garantida na forma de Organismo de Controle Social - OCS, é constituído por seis famílias, todas residentes do Vale do Ribeira, município de Rio Branco do Sul (PR), Comunidade do Tigre. 0 casal de produtores Divanete de Jesus Taborda e Silvestre de Jesus Taborda, integrantes do ACARS, tomou a iniciativa da construção da estrutura em sua propriedade, mantendo o formato da cama sobreposta, mas com pisos e paredes utilizando madeira e concreto (figura 1B).

Outra particularidade desta construção é que a cama sobreposta foi constituída por diversos materiais, como: palhada de milho picadas, folhas de árvores e acícula de pinus, todas secas. Vale ressaltar aqui que o uso de diferentes materiais em relação à construção original é muito bem vinda, tendo em vista o incentivo do núcleo $\mathrm{P}+\mathrm{O} / \mathrm{CPRA}$ para que se utilizassem materiais já presentes na propriedade e de baixo custo. 0 processo de construção se iniciou em maio de 2018 e foi até junho do mesmo ano, este foi acompanhado pela equipe de filmagens Canteiro Audiovisual que produziu um vídeo relatando a experiência do grupo com a construção. As filmagens e a construção envolveram todos os integrantes do grupo ACARS, os técnicos do P+O/CPRA, Emater, Projeto Agroecologia Acontece e o Projeto Produção em Base Agroecológica na Região Metropolitana de Curitiba.

A iniciativa da construção da pocilga na propriedade foi da Dona Divanete e do Seu Silvestre, mas esta incentivou também outra família do grupo, o casal Zilva Lima Saldanha e João Monteiro Lima. Estes construíram duas pocilgas, pois pretendem ampliar a criação de suínos na propriedade porque perceberam que neste formato de estrutura a mão de obra é reduzida e os animais têm mais conforto, melhorando a sanidade destes. A pocilga deles foi construída de forma mais rústica, com troncos e galhos de árvores que já existiam na propriedade, piso de concreto e cepilho para a cama.

\section{CONSIDERAÇÕES FINAIS}

O objetivo da proposta de multiplicação da Bambucilga foi atingido, ajustando a adequação das propriedades à manutenção da certificação orgânica. Algumas famílias de outros grupos de produtores já estão aguardando o auxílio dos bolsistas do P+O/CPRA para construção das estruturas em suas propriedades. 


\section{REFERÊNCIAS}

[1] Brasil. Instrução normativa no 46, de 06 de outubro de 2011. Lei no 10831, de 23 de dezembro de 2003. Diário Oficial da República Federativa do Brasil, Poder Executivo, Brasília, DF, 06 Outubro. 2011. Seção 1, p. 8.a.

[2] Colaço, L. C. et al. Caderno de Sugestões: Criação de Suínos em Cama Sobreposta. Programa Paranaense de Certificação de Produtos Orgânicos/Centro Paranaense de Referência em Agroecologia. Supergraf, Curitiba, 2017.

[3] Dalla Costa, O. A. Oliveira, P. A V. de. Holdefer, C. Lopes, E. J. C. Sangoi, V. Sistema Alternativo de Criação de Suínos em Cama Sobreposta para Agricultura Familiar. Comunicado Técnico 146. Embrapa, 2006. 


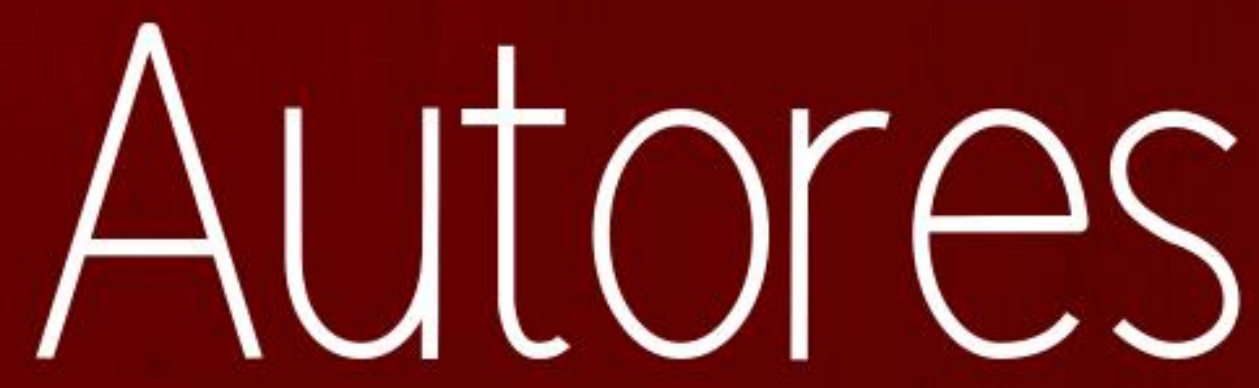




\section{ABELARDO ANTÔNIO DE ASSUNÇÃO MONTENEGRO}

Possui graduação em Engenharia Civil pela Universidade Federal de Pernambuco (1985), mestrado em Hidráulica e Saneamento São Carlos pela Universidade de São Paulo (1989) e doutorado em Water Resources - University of Newcastle Upon Tyne (1997). Tem pós-doutorado em modelagem hidrologica pelo Centre for Ecology and Hydrology de Wallingford, Inglaterra (2008). É professor titular da Universidade Federal Rural de Pernambuco, e membro permanente do Programa de PósGraduação em Engenharia Agrícola da UFRPE. Tem experiência na área de Recursos Hídricos e Engenharia Agrícola e Ambiental, com ênfase em Irrigação e Drenagem.

\section{ADROALDO DIAS ROBAINA}

Graduação em Agronomia, Mestrado em Recursos Hídricos, Doutorado em Engenharia Civil, Professor Titular no Departamento de Engenharia Rural da Universidade Federal de Santa Maria.

\section{ALBERTO CARVALHO FILHO}

Prof. Dr. Associado II Relação Solo-Mecanização-Planta Instituto de Ciências Agrárias Universidade Federal de Viçosa - Campus de Rio Paranaíba.

\section{ALCEU CERICATO}

Possui graduação em Engenharia Agronômica pela Universidade Federal de Pelotas (1991) especialização em Administração Rural pela UNOESC (1998), Mestrado em Administração pela Universidade Federal de Santa Catarina (2001), e Doutorado pela UNAM - AR (2013). Revalidado pela UFRJ - Universidade Federal do Rio de Janeiro (2016). Atualmente é professor e coordenador de cursos de pós-graduação, em nível de especialização na Universidade do Oeste de Santa Catarina - Unoesc. É coordenador do curso de Agronomia da Unoesc, Campus de Maravilha. Suas áreas de domínio são: Gestão Ambiental, Direito e Legislação Ambiental, Engenharia de Produção e Produção Vegetal.

\section{ALDIR CARPES MARQUES FILHO}

Doutorando em Agronomia (Energia na Agricultura), UNESP/Botucatu.

\section{ANA CARLA DOS SANTOS GOMES}

Graduação em Engenharia Agrícola, Mestrado em Engenharia Agrícola, Doutorado em Engenharia Agrícola, Professora do Instituto Federal Farroupilha - Campus Alegrete.

\section{ANA KARLA DA SILVA OLIVEIRA}

Possui Técnico em Agronegócio pelo Serviço de Aprendizagem Rural ( SENAR -MA). Atualmente é graduando em Engenharia Agrícola pelo Centro de Ciências Agrárias e Ambientais da Universidade Federal do Maranhão (CCAA/UFMA). Possui Técnico em Agronegócio pelo Serviço de Aprendizagem Rural (SENAR-MA). Atualmente é Bolsista pelo Conselho Nacional de Desenvolvimento Científico e Tecnológico (CNPq).

\section{ANA RITA COSTENARO PARIZI}

Graduação em Engenharia Agrícola, Mestrado em Engenharia Agrícola, Doutorado em Engenharia Agrícola, Professora do Instituto Federal Farroupilha - Campus Alegrete. 


\section{ANDRÉ SORDI}

Graduação em Agronomia pela Universidade Comunitária da Região de Chapecó (UNOCHAPECÓ). Mestrado em Ciências do Solo pela Universidade Federal do Paraná (UFPR). Professor da Universidade do Oeste de Santa Catarina (UNOESC).

\section{CAMILA VIEIRA VIANA FARHATE}

Engenheira Agrônoma formada pela Universidade Estadual de Maringá - UEM (2012), mestra (2015) e doutora (2019) em Engenharia Agrícola pela Universidade Estadual de Campinas UNICAMP.

\section{CARLOS AUGUSTO ALVES CARDOSO SILVA}

Graduando em engenharia agrícola pela Universidade Federal do Maranhão - UFMA, no Centro de Ciências Agrárias e Ambientais - CCAA, campus IV, Chapadinha/MA. Atualmente é bolsista de Iniciação Tecnológica e Industrial do CNPq - Nível A, com desenvolvimento de pesquisas em eventos climáticos extremos em modelos de regimes de incêndios florestais.

\section{CÁTIA HERMES}

Graduada em Zootecnia na Universidade Tecnológica Federal do Paraná - Campus Dois Vizinhos (UTFPR, 2016). Consultora Sebrae em Agropecuária (2020), Bolsista do Programa Paraná Mais Orgânico (P+O) no Centro Paranaense de Referência em Agroecologia-CPRA, (2017-2019). Experiência profissional com Avicultura Colonial e Orgânica, Bovinos Leiteiros Orgânicos e convencionais, Ovinos e Caprinos de corte e Bubalinos.

\section{CHAIANE GUERRA DA CONCEIÇÃO}

Graduação em Engenharia Agrícola, Mestrado em Engenharia Agrícola, Doutoranda em Engenharia Agrícola, Professora do Instituto Federal de Educação, Ciência e Tecnologia do Rio Grande do Sul Campus Sertão.

\section{CLAUDIA KLEIN}

Engenheira agrônoma, doutora em Agronomia - Produção Vegetal, professora pela Universidade do Oeste de Santa Catarina.

\section{CRISTIANE D. PAIER}

Zootecnista- UTFPR, Mestrado em Agronomia- UTFPR, Doutorado em Agronomia- UFGD.

\section{CRISTIANO RESCHKE LAJUS}

Engenheiro Agrônomo, formado em 02 de março de 2002 pela Universidade do Oeste de Santa Catarina (UNOESC), Chapecó, SC. Os cursos de Mestrado e Doutorado em Agronomia, área de concentração em Produção Vegetal, na Universidade de Passo Fundo foram concluídos em fevereiro de 2004 e outubro de 2010. Atualmente é Coordenador do Programa de Pós-graduação Stricto Sensu Doutorado (DINTER) em Ciência e Engenharia de Materiais UFSCar/Unochapecó e professor do Mestrado em Tecnologia e Gestão da Inovação da Universidade Comunitária de Chapecó e da Universidade do Oeste de Santa Catarina. Tem experiência na área de Agronomia, com ênfase em Produção Vegetal e Agricultura de Precisão. 


\section{DANIEL ALBIERO}

Possui graduação em Engenharia Agrícola pela Faculdade de Engenharia Agrícola da Unicamp, graduação em Física pela Unicamp, mestrado e doutorado em Engenharia Agrícola pela Unicamp. Atualmente é Professor Doutor de Projetos de Máquinas e Robótica da Faculdade de Engenharia Agrícola (FEAGRI) da Universidade Estadual de Campinas (UNICAMP), Coordenador de Extensão da FEAGRI/UNICAMP. Tem experiência na área de Engenharia Agrícola, com ênfase em dinâmica do solo, projeto e avaliação de máquinas agrícolas, máquinas agroecológicas, equipamentos para a agricultura familiar, óptica aplicada a engenharia agrícola, construções rurais com material alternativo, propriedades físicas e mecânicas de material biológico, aviação agrícola, gestão de qualidade na agricultura, energia na agricultura (biomassa e eólica) e robótica na agricultura.

\section{DAVI GABRIEL AZEVEDO BESSON}

Engenheiro Agronômo pela Escola Superior de Agricultura "Luiz de Queiroz" (ESALQ/USP), atuou como coordenador de Agricultura de Precisão no Grupo Terra Santa Agro S.A.

\section{DÉBORA ESTER SANTOS FIALHO}

Graduada em Ciências Biológicas com ênfase em Gestão Ambiental pela PUC Minas, Especialista em Engenharia Ambiental pela Faculdade de Engenharia de Minas Gerais, Mestre em Tecnologias e Inovações Ambientais pela UFLA.

\section{DIEGO HENRIQUE DOS SANTOS}

Graduando do curso de Zootecnia da UFSM em Palmeira das Missões-RS. Bolsista do Fundo de Apoio à Extensão da UFSM.

\section{DJEIMES LUIZ SADOWSKI CELANTE}

Acadêmico de Agronomia no Instituto Federal Catarinense Campus Rio do Sul.

\section{EDIVAN SANTIN}

Acadêmico do curso de Agronomia $10^{\circ}$ período pela Universidade do Oeste de Santa Catarina UNOESC.

\section{EDUARDO AROUCHE DA SILVA}

Possui Técnico em Agronegócio pelo Serviço de Aprendizagem Rural (SENAR-MA). Atualmente é graduando em Engenharia Agrícola pelo Centro de Ciências Agrárias e Ambientais da Universidade Federal do Maranhão (CCAA/UFMA). É membro dos grupos de estudos, Grupo de Estudos em Tecnologia e Agricultura de Precisão (GETAP) e do Núcleo de Estudos e Pesquisas em Fitotecnia (NEPF), atuando nas áreas de Mecanização Agrícola e Fitotecnia. Atualmente é bolsista de iniciação científica (PIBIC-UFMA).

\section{EDUARDO JAVIER MARONE}

Eduardo Javier Marone, formado em Engenharia Agronômica pela Universidade Federal do Paraná (2012), especialização em Gestão Ambiental pelo PECCA-UFPR(2014), bolsista do Programa Paraná Mais Orgânico(2014-2019), Inspetor em sistemas orgânicos de produção(2015-2019). 


\section{EDUARDO SILVA DOS SANTOS}

Possui graduação em Engenharia Agrícola e Ambiental pela Universidade Federal Rural de Pernambuco (2007). Mestrado e Doutorado em Engenharia Agrícola (UFRPE). Tem experiência na área de Engenharia Agrícola, com ênfase em Engenharia de água e solo, atuando principalmente nos seguintes temas: sustentabilidade e aluvião.

\section{ELIZEU SOUZA LIMA}

Doutorado em Engenharia Agrícola pela Faculdade de Engenharia Agrícola, Universidade Estadual de Campinas - UNICAMP (2015-2019). Mestrado em Agronomia, Sistema de Produção, pela UNESP - Universidade Estadual Paulista Júlio de Mesquita Filho, Campus Ilha Solteira (2015). Graduado em Engenharia Florestal pela UEMS - Universidade Estadual de Mato Grosso do Sul, unidade de Aquidauana (2013).

\section{FABIANA TEIXEIRA HOINACKI}

Formada em Administração de empresas pela Faculdade de Campina Grande do Sul FACSUL (2012), bolsista do programa Paraná mais Orgânico na Área administrativa a 8 anos.

\section{FÁBIO LEONARDO PRANTE BOLFE}

Acadêmico do curso de Agronomia $10^{\circ}$ período pela Universidade do Oeste de Santa Catarina UNOESC.

\section{FABRÍCIO CAMPOS MASIERO}

Engenheiro Agrônomo, Professor Doutor área de Máquinas e Mecanização Agrícola no Instituto Federal Catarinense Campus Rio do Sul.

\section{FÁTIMA RESENDE LUIZ FIA}

Graduada em Engenharia Agrícola pela Universidade Federal de Lavras (UFLA). Mestre e Doutora em Engenharia Agrícola (Recursos Hídricos e Ambientais) pela Universidade Federal de Viçosa (UFV). Atualmente ocupa o cargo de professor Associado do Departamento de Recursos Hídricos e Saneamento (DRS) da UFLA. Faz parte do corpo docente dos Programas de Pós-Graduação em Engenharia Ambiental, Engenharia Agrícola e do mestrado profissional em Tecnologias e Inovações Ambientais da UFLA. Atua na área de Engenharia Agrícola e Ambiental, com ênfase em qualidade de água, tratamento de águas de abastecimento e residuárias domésticas e agroindustriais.

\section{GABRIEL GANANCINI ZIMMERMANN}

Bolsista de Iniciação Científica do CNPq, Acadêmico de Agronomia no Instituto Federal Catarinense Campus Rio do Sul.

\section{GABRIEL Q. DE OLIVEIRA}

Engenheiro Agrônomo graduado pela Universidade Estadual de Mato Grosso do Sul . Mestre em Agronomia (Produção Vegetal) pela Universidade Estadual de Mato Grosso do Sul e Doutor em Agronomia pela Universidade Federal da Grande Dourados. 


\section{GABRIELA CAVALHEIRO CRODA}

Graduanda do curso de Zootecnia da UFSM em Palmeira das Missões-RS. Auxiliar administrativa e de manejo de equinos do Centro Equestre Ranch.

\section{GABRIELA DE LUZIA BARROS MESQUITA}

Graduanda em Engenharia Ambiental e Sanitária pela Universidade Federal de Lavras.

\section{GIDEON UJACOV SILVA}

Graduação em Engenharia Agrícola pelo Instituto Federal Farroupilha - Campus Alegrete.

\section{GUILHERME A. BÍSCARO}

Possui graduação em Engenharia Agrícola -UFLA, mestrado e doutorado em Irrigação e Drenagem UNESP.

\section{INGRID NEHMI DE OLIVEIRA}

Formada em Engenharia Agrícola pela Universidade Estadual de Campinas (2014), Mestra e atualmente aluna de Doutorado em Engenharia Agrícola na Universidade Estadual de Campinas. Tem experiência na área de Engenharia Agrícola com ênfase em Pós-Colheita e Água e Solos.

\section{IURY ALBERTO MOTA DE LIMA}

Graduando em Engenharia Agronômica na Universidade da Integração Internacional da Lusofonia Afro Brasileira (UNILAB). Atualmente é bolsista voluntário da Ação Produção Sustentável de Alimentos- Quintais Produtivos com Gestão Familiar: Produzindo, Consumindo e Progredindo.

\section{JEFFERSON SANDI}

Prof. Doutor em Agronomia (Energia na Agricultura), Faculdade La Salle-MT, Rio Verde.

\section{JOÃO ANTÔNIO DA CONCEIÇÃO}

Graduação em Engenharia Agrícola.

\section{JOÃO CÉLIO DE ARAÚJO}

Engenheiro Agrônomo, Professor Doutor no Instituto Federal Catarinense Campus Rio do Sul.

\section{JOÃO JOSÉ DA SILVA JUNIOR}

Professor Adjunto na Faculdade de Agronomia e Medicina Veterinária FAV/UNB, atuou como instrutor na formação profissional rural pelo SENAR/MG capacitando trabalhadores nas seguintes atividades: operação e manejo de sistemas de irrigação localizada (microaspersão e gotejamento), sistemas convencionais de irrigação por aspersão convencional, e sistemas de irrigação por aspersão autopropelido. Foi Professor Substituto no Departamento de Engenharia Agrícola da UFLA no período de fevereiro a julho de 2013 ministrando as disciplinas de Qualidade Ambiental e Saneamento I. Doutorado pelo programa de pós-graduação em Recursos Hídricos em Sistemas Agrícolas da Universidade Federal de Lavras, Área de concentração de Engenharia de água e solo. Foi Tutor a Distância no curso de Pós-graduação Lato Sensu em Educação Ambiental UFLA/UAB/CEAD das disciplinas de Avaliação de Projetos Ambientais, Gestão de Movimentos da Juventude e Ambiente de Orientação do TCC. Atuou como tutor das disciplinas Antropologia I e II e de Sociologia I, II e III do curso de Pedagogia a distância da UFLA/UAB/CEAD . Foi estagiário do PET/Agronomia (Programa de Educação Tutorial) da Universidade Federal do Recôncavo Baiano 
no período de Julho de 2003 a Janeiro de 2009 . Têm experiência na área de irrigação e na área de manejo de fertirrigação foi estagiário da Empresa Brasileira de Pesquisa Agropecuária EMBRAPA CNPMF Laboratório de Irrigação e Fertirrigação de fruteiras tropicais .Têm experiência na área de Ciência e Tecnologia de Alimentos, com ênfase em Tecnologia de Produtos de Origem Vegetal, e de pós colheitas de frutos tropicais atuando principalmente nos seguintes temas: acerola, caracterização físico-química, opuntia ficus, caracterização física., propagação, vegetativa e umbucajazeira, populações, variabilidade genética.

\section{JOSÉ CARLOS KUSMA}

Acadêmico de Agronomia no Instituto Federal Catarinense Campus Rio do Sul.

\section{JULIANA SARUBBI}

Médica Veterinária pela - UEL, com mestrado e doutorado em Construções Rurais e Ambiência na FEAGRI/UNICAMP, com ênfase em Bem-Estar Animal. Professora Associada da UFSM-Palmeira das Missões/RS, docente do Programa de Pós-Graduação em Agronegócio da UFSM. É coordenadora do Laboratório de Ambiência e Bem-Estar Animal (LAABEA-UFSM) e do Grupo de Estudos e Pesquisas em Suinocultura (GPS-UFSM). Tem experiência nas áreas de Comportamento Animal, Ambiência e Bem-Estar Animal, com estudos direcionados a suínos e equinos, atuando principalmente em pesquisa relacionadas à interação homem-animal e termografia infravermelha e suas interrelações com o bem-estar animal.

\section{KAROLINE K. B. DREHMER}

Engenheira Agrícola pela UFGD.

\section{KLÉBER PEREIRA LANÇAS}

Prof. Doutor em Agronomia (Energia na Agricultura), UNESP/FCA.

\section{LEANDRO MARIA GIMENEZ}

Engenheiro Agrônomo pela Universidade de São Paulo (2000), mestre em Máquinas Agrícolas e Doutor em Engenharia de Sistemas Agrícolas na mesma Universidade. Tem experiência com pesquisa em sistemas conservacionistas para a produção de grãos e fibras com ênfase nas áreas de Mecanização e Agricultura de Precisão. Atualmente é professor e orientador nos níveis de graduação e pós graduação no departamento de Engenharia de Biossistemas da Escola Superior de Agricultura "Luiz de Queiroz", ESALQ-USP.

\section{LENON HENRIQUE LOVERA}

Engenheiro Agrônomo pela Universidade Estadual de Mato Grosso do Sul em 2013, mestre pela faculdade UNESP de ilha solteira em 2015 e doutor em Engenharia Agrícola pela Feagri - UNICAMP em 2019.

\section{LETÍCIA ALMEIDA}

Engenheira Agrônoma graduada pela Universidade Federal de Viçosa - Campus Rio Paranaíba. Mestrando do programa de pós-graduação em Agronomia - Produção Vegetal, trabalhando na linha de pesquisa "Manejo de Pragas, Doenças e plantas daninhas" pela Universidade Federal de Viçosa Campus Rio Paranaíba.

\section{LUÃ CARLOS COLAÇO}

Luã Carlos Colaço, Engenheiro Agrônomo formado em 2018 pela Pontifícia Universidade Católica do Paraná - PUCPR. 


\section{LUCIANO O. GEISENHOFF}

Graduação em Engenharia Agronômica pela Universidade Federal de Lavras, Doutorado em Engenharia Agrícola pela Universidade Federal de Lavras (2010) Mestrado em Engenharia Agrícola pela Universidade Federal de Lavras (2008).

\section{LUÍS GUSTAVO CHAVES DA SILVA}

Graduado em Engenharia Agronômica pela Universidade Federal Rural de Pernambuco, mestrado em Agronomia (Fitopatologia) pela Universidade Federal de Viçosa e doutorado em Fitopatologia pela Universidade Federal Rural de Pernambuco. Tem experiência na área de Agronomia, com ênfase em Fitopatologia, atuando principalmente nos seguintes temas: Epidemiologia, controle de doenças, resistência de plantas, geoprocessamento e biologia molecular. Atuando como professor pesquisador na UNILAB.

\section{LUIZ FERNANDO COSTA RIBEIRO SILVA}

Engenheiro Agrônomo graduado pela Universidade Federal de Viçosa - Campus Rio Paranaíba. Mestrando do programa de pós-graduação em Agronomia - Produção Vegetal, trabalhando na linha de pesquisa "Mecanização Agrícola, Manejo e Conservação do solo e da água" pela Universidade Federal de Viçosa - Campus Rio Paranaíba.

\section{LUIZ GUILHERME MEDEIROS PESSOA}

Engenheiro Agrônomo e Doutor em Ciência do Solo pela Universidade Federal Rural de Pernambuco. Atualmente é professor Adjunto na Universidade Federal Rural de Pernambuco/Unidade Acadêmica de Serra Talhada. Professor permanente dos Programas de PósGraduação em Produção Vegetal (UAST/UFRPE) e Engenharia Ambiental (UFRPE/Sede).

\section{MARCIA XAVIER PEITER}

Graduação em Agronomia, Mestrado em Engenharia Agrícola, Doutorado em Engenharia Civi, Professora Associada da Universidade Federal de Santa Maria.

\section{MARIA CECILIA VIEIRA TOTTI}

Possui graduação em Gestão Ambiental pelo Instituto Federal de Educação, Ciência e Tecnologia do Sul de Minas Gerais (2017). Atualmente é mestranda em Engenharia Agrícola pela Universidade Estadual de Campinas.

\section{MARIANA NARDI FURTADO}

Estudante de Engenharia Florestal na UnB, Tem experiência na área de Recursos Florestais e Engenharia Florestal, com ênfase em Recursos Florestais e Engenharia Florestal.

\section{MATHEUS BARCELOS DE SOUSA}

Estudante de Agronomia na Universidade de Brasília, tem experiencia em modelagem e determinação de parâmetros físico-hídricos do solo, manejo de irrigação e fertirrigação.

\section{MAURA SEIKO TSUTSUI ESPERANCINI}

Prof. Doutora, Departamento de Economia e Sociologia Rural, UNESP/FCA 


\section{MAX CÉSAR DE ARAÚJO}

Graduado em Engenharia Agrícola pela Universidade Federal da Paraíba, mestre em Engenharia Mecânica pela Universidade Federal da Paraíba e doutor em Engenharia Agrícola pela Universidade Estadual de Campinas. Atualmente é Professor Associado no Instituto de Desenvolvimento Rural da Universidade da Integração Internacional da Lusofonia Afro Brasileira (UNILAB) . Tem experiência na área de engenharia agrícola, com ênfase em projeto de máquinas e equipamentos agrícolas, atuando principalmente nos seguintes temas: beneficiamento de produtos agrícolas, mecanização e máquinas agrícolas, como também, energias alternativas para a agricultura. Atualmente é Pró-Reitor de Relações Institucionais da Universidade da Integração Internacional da Lusofonia Afro Brasileira (UNILAB).

\section{MONIQUE DENIS CABRAL}

Graduação em Engenharia Agrícola pelo Instituto Federal Farroupilha - Campus Alegrete.

\section{MURILO BATTISTUZZI MARTINS}

Prof. Doutor em Agronomia (Energia na Agricultura), UEMS/Cassilândia.

\section{OTÁVIO PIVOTO}

Graduação em Engenharia Agrícola pelo Instituto Federal Farroupilha - Campus Alegrete.

\section{PAULO S. V. FILHO}

Engenheiro Agrícola pela Universidade Federal da Grande Dourados.

\section{RAFAELA PAULA MELO}

Possui graduação em Agronomia pela Universidade Federal do Ceará (UFC), mestrado e doutorado em Engenharia Agrícola pela Universidade Federal do Ceará (UFC) possuindo experiência na área de mecanização agrícola, projeto de máquinas agrícolas e avaliação do desempenho de máquinas agrícolas. Atualmente é professora substituta da Universidade da Integração Internacional da Lusofonia Afro-Brasileira (UNILAB).

\section{RICARDO KOZOROSKI VEIGA}

Engenheiro Mecânico, Professor Doutor no Instituto Federal Catarinense Campus Rio do Sul.

\section{SAIONARA PEREIRA XAVIER}

Graduanda do curso de Zootecnia da UFSM em Palmeira das Missões-RS. Bolsista do Fundo de Apoio à Pesquisa da UFSM.

\section{VALCIR INÁCIO WILHELM}

Técnico em Agropecuária, atuou na extensão rural do Paraná por 38 anos, sendo 13 destes no CPRA com ênfase em Bambu e Meliponicultura, Pelo CPRA, também atuou como coordenador da equipe do Paraná Mais Orgânico.

\section{VITOR INÁCIO HOELSCHER}

Graduado em Zootecnia pela UFSM - Palmeira das também possui experiência na área de suinocultura, equinocultura, bem-estar animal e termografia infravermelha. Mestre em Agronegócios pela UFSM. Supervisor de disciplina no curso de Gestão do Agronegócio na Uniasselvi - Indaial- SC. 


\section{ZIGOMAR MENEZES DE SOUZA}

Graduado em Agronomia pela Universidade Federal do Amazonas (1998), Mestrado em Agronomia pela Universidade Estadual Paulista Júlio de Mesquita Filho (2000) e Doutorado em Agronomia (Produção Vegetal) pela Universidade Estadual Paulista Júlio de Mesquita Filho (2004). Realizou Pós-Doutorado na Universidade Estadual de Campinas (UNICAMP) em 2006. Atualmente é Professor Doutor da Universidade Estadual de Campinas (Faculdade de Engenharia Agrícola). 
